DE REGERING VAN SUNAN MANGKURAT I TEGAL WANGI, VORST VAN MATARAM

1646-1677

I 
H.J. de Graaf - 978-90-04-28657-3 Downloaded from Brill.com $\odot 4 / 26 / 2023$ 02:24:41PM via free access 


\title{
VERIIANDELINGEI
}

VAN HET KONINKLIJK INSTITUUT VOOR

TAAL-, LAND- EN VOLKENKUNDE

DEEL 33

\section{DE REGERING VAN SUNAN MANGKU-RAT I TEGAL-WANGI, VORST VAN MATARAM 1646-1677}

\author{
DOOR \\ Dr H. J. DE GRAAF \\ I \\ DE ONTBINDING VAN HET RIJK
}

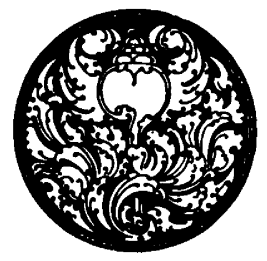

'S.G RAVENHAGE-MARTINUS NIJHOFF-1961 
H.J. de Graaf - 978-90-04-28657-3 Downloaded from Brill.com $\odot 4 / 26 / 2023$ 02:24:41PM via free access 


\section{INLEIDING.}

Aan het samenstellen van het derde deel der „Vorsten van Mataram” waren bijzondere moeilijkheden verbonden, hetgeen zowel in de aard van het onderwerp als in die der bronnen gelegen was.

Wat de Javaanse bronnen betreft, de overlevering omtrent de regering van sunan Mangku-Rat Tegal-Wangi is blijkbaar pas verscheidene tientallen jaren na zijn tragische dood opgetekend en daardoor is zij veel beknopter geworden, dan wij wel zouden wensen. Van een van jaar tot jaar optekenen der feiten, zoals dat voor de eerste helft van zijns vaders regering het geval is, is geen sprake; slechts enige voorname en opvallende dynastieke gebeurtenissen worden gememoreerd. Bovendien zullen wij kunnen vaststellen, dat sommige verhalen door elkaar zijn gehaald, dat men de chronologische volgorde uit het oog heeft verloren en dat bepaalde reeksen van feiten, b.v. die betreffende 's Vorsten oom pg. Purbaja, de fidus Achates der overlevering, of zijn weggelaten, of van karakter veranderd. Een zeer welkome aanvulling zouden de jaartalbabads aanbieden, die voor ieder jaar feiten vermelden, indien de omschrijving dezer gebeurtenissen niet zo beknopt was, dat men dikwijls moet raden naar hetgeen er in werkelijkheid geschied is.

Betrekkelijk rijk zijn de Nederlandse bronnen doordat er negenmaal cen Nederlands gezantschap naar Mataram trok en sedert 1651, met een enkele onderbreking van 1660 -62, een kantoor der Compagnie in Japara bestond. Doch er zijn helaas leemten. Van het tweede gezantschap van Van Goens (1649), dat zeer belangrijk moet zijn geweest, is het verslag, vermoedelijk door waterschade, verloren gegaan. De brieven uit Japara zijn pas van 1664 af volledig in het Bataviaas inkomend briefboek bewaard gebleven. Voor de vroegere jaren moeten wij ons tevreden stellen met uittreksels in het Bataviase Dagregister, dat echter slechts voor de jaren 1648, 1653, 1656-57, 1659, 1661, 1663 en vlg. bewaard bleef. Voor de ontbrekende jaren moeten wij ons vergenoegen met de resolutiën, de generale missiven en het uitgaand briefboek.

Niet steeds waren onze Nederlandse berichtgevers bekwaam of goed ingelicht. Slechts één resident van Japara, Jacob Couper, verstond behoorlijk Javaans, de anderen moesten zich met Maleis behelpen. 
Behalve Rijklof van Goens, die vijf maal naar de hofstad opreisde, ondernamen alle gezanten slechts éénmaal de reis naar Mataram, zodat zij van opgezamelde ervaring geen gebruik konden maken. Sommige residenten, niet alle, waren bepaald onbekwaam, om van andere ondeugden maar te zwijgen, b.v. Bernhard Volsch en David Luton. Hun inlichtingen zullen daarmede in overeenstemming zijn geweest. De laatste kreeg ook een vermaning om vlijtiger te schrijven.

Uiteraard was de gezichtskring dezer Nederlandse berichtgevers beperkt. Hun voornaamste taak was de loge van Japara aan haar doel te laten beantwoorden, dus winst te maken. Daarnaast deelden zij ook veel politiek nieuws mede, voor zover dit voor de handel van belang was. Beschikkend over spionnen en tolken, weten zij vrij veel over Japara en de naaste omgeving, ook wel iets over de Kraton in Zuid-MiddenJava en zijn bewoners te verhalen, doch de rest van Java blijft meestal in een schemerduister gehuld, hetgeen onze kijk op het geheel niet bevordert. Met name zouden wij gaarne omtrent de gebeurtenissen in Oost-Java, van waaruit de grote opstand tegen het vorstenhuis zou ontstaan, beter zijn ingelicht dan nu het geval is. Door deze eenzijdige berichtgeving ontstaat het gevaar, dat wij de gebeurtenissen in Japara gaan overschatten.

Andere dan de genoemde bronnen ontbreken bijkans geheel. De Portugezen hebben blijkbaar alle belangstelling voor Java verloren. De Engelsen onderhouden in Japara tot 1652 een kleine loge en worden dan uitgezet om onbekende reden. De gedrukte bronnen wekken niet de indruk, dat er behalve misschien losse opmerkingen, grote samenhangende berichten omtrent Mataram en het Mataramse hof in Londen aanwezig zijn.

Een eigenaardige moeilijkheid is, dat er weliswaar vrij veel uitspraken van de Susuhunan overgeleverd zijn, doch dat deze een bijzondere interpretatie behoeven ten einde op hun rechte waarde en naar hun juiste bedoeling gewaardeerd te worden.

Ten slotte hebben wij de moeilijkheid, dat onze biografie een psychopaat tot held heeft, wiens handelingen en woorden niet met de normale maatstaf gemeten kunnen worden. Vandaar dat soms lange uiteenzettingen noodzakelijk zijn, om uit het zeer verspreide materiaal conclusies te kunnen trekken. Daarom is het wenselijk alle overgeleverde uitspraken van de hoofdpersoon zo getrouw mogelijk op te nemen.

Vandaar dat het onmogelijk bleek alle gegevens en uiteenzettingen in één deel onder te brengen. Verdeling over twee delen was noodzakelijk. 
Het eerste deel zal dienen te bevatten: na een inleiding over geboorte, naamgeving en jeugd van de Sunan, een beschrijving van de Kraton Plèrèd en een opsomming der voornaamste hofdienaren. De rest van het deel is gewijd aan Mataram's verhouding tot de buitenwereld, t.w. eerst zijn relaties met de Indonesische rijken: Bantam, Bali en Balambangan, Palembang, Djambi, Borneo en Makassar.

De meeste ruimte wordt echter in beslag genomen door des Sunan's verhouding tot de V.O.C., niet slechts, omdat wij hieromtrent de meeste berichten bezitten, doch ook omdat de Compagnie in het gedachtenleven van de Vorst een steeds grotere plaats moet zijn gaan innemen.

In het tweede deel zal de binnenlandse historie van het rijk meer tot haar recht komen, die haar einde vond in de grote opstand, leidende tot de ondergang van de Kraton van Mataram. Hierin zal tevens een register voor beide delen opgenomen worden. 
H.J. de Graaf - 978-90-04-28657-3 Downloaded from Brill.com $\odot 4 / 26 / 2023$ 02:24:41PM via free access 


\section{INHOUD.}

I. Jeugd en regeringsaanvaarding van Sunan Mangku-Rat

Tegal-Wangi.

Geboorte en naamgeving . . . . . . . . . . . . 1

Jeugdjaren . . . . . . . . . . . . . . . . 2

Verheffing . . . . . . . . . . . . . . . 3

Tg. Wira-Guna . . . . . . . . . . . . . . . 4

Pg. Purbaja . . . . . . . . . . . . . . . . 5

De vorstelijke titel . . . . . . . . . . . . . . 8

II. De kraton Plèrèd en de voornaamste ambtenaren.

De Kraton en zijn waterwerken . . . . . . . . . 10

De voornaamste hofdienaren: de tumenggung Mataram 14

De latere opperstrandheren . . . . . . . . . . . 19

De bestuursorganisatie volgens Van Goens . . . . . . 19

De Rijkstresoriers . . . . . . . . . . . . . . 20

III. Eerste regeringsdaden.

De eerste regeringsjaren volgens Van Goens . . . . . 23

De Balambanganse veldtocht volgens de overlevering . . 25

De aanslag van pg. Alit op de Kraton. 1647 . . . . . 27

Beschouwing over de eerste jaren . . . . . . . . . 30

De moord op de ,geestelijken" . . . . . . . . . . . . 32

Het eerste conflict met pg. Purbaja . . . . . . . . 34

Mataram's buitenlandse politiek . . . . . . . . . 36

IV. De verhouding tot Bantam en Bali.

Bantam-Mataram. 1646-1652 . . . . . . . . . 39

Het eerste Bantams gezantschap. 1650 . . . . . . . 40

De Pagarage. 1650 . . . . . . . . . . . . . 41

De politieke ommekeer. 1652 . . . . . . . . . . 52

Breuk in de Bantams-Mataramse vriendschap. 1656 . . 44

Het tweede Bantams gezantschap. 1657 . . . . . . . 45

Reden van Mataram's oorlog met Bantam . . . . . . 45

De tocht naar Krawang. 1657-58 . . . . . . . . . 46

De vredesbesprekingen. 1659 . . . . . . . . . . . . 49

De verhouding tot Bali . . . . . . . . . . . . 50

V. Mataram's politiek in Sumatra.

Mataram's verhouding tot Palembang en Djambi.

$1651-56$. . . . . . . . . . . . . . . . . 53 
De moord op Ockersz. voor Palembang. 1658 . . . . 54

De tuchtiging van Palembang. 1658-59 . . . . . . 57

Indruk van Palembang's bestraffing. 1659 . . . . . . . 58

Latere Palembangse gezantschappen. 1660-68 . . . . 60

Djambi's breuk met Mataram. 1663 . . . . . . . . 64

VI. Mataram's verhouding tot Borneo en Celebes.

Borneo verloren. 1661 . . . . . . . . . . . . 67

Mataram en Makassar . . . . . . . . . . . . 68

Het eerste Makassaarse gezantschap. 1656-57 . . . . 69

Het tweede Makassaarse gezantschap. 1658-59 . . . . 71

VII. De vriendschap met de Compagnie.

De vredessluiting. 1646 . . . . . . . . . . . . . 74

Het gezantschap van Hermansz. 1646 . . . . . . . . 77

Het gezantschap van Wonderaer-Van Goens. 1648. . . 79

Het 2e gezantschap van Van Goens. 1649 . . . . . 80

Het 3e gezantschap van Van Goens. 1651 . . . . . 81

VIII. Het stelsel der beide opperstrandheren.

De stad Japara in de 2e helft der 17e eeuw . . . . . 82

De positic der Nederlanders in Japara . . . . . . . 83

De eerste residenten. $1651-55$. . . . . . . . . 85

De tolken voor het Javaans . . . . . . . . . . 86

De bouw der eerste jachten. 1651-52 . . . . . . . 87

Beheer der stranden. $1648-51$. . . . . . . . . 88

Grieven van de Sunan . . . . . . . . . . . . 89

De twee opperstrandheren. $1651-57$. . . . . . . . . 91

De handelsbelemmeringen. 1652 . . . . . . . . . 92

Het 4e gezantschap van Van Goens. 1652 . . . . . . . 94

Het Javaanse tegengezantschap. 1653 . . . . . . . 95

Het gezantschap van Van Gent. 1653 . . . . . . . 97

Het 5e gezantschap van Van Goens. 1654 . . . . . . 97

IX. Het eerste conflict.

Besluit tot een gezantschap. 1655 . . . . . . . . . 100

Het gezantschap van Kieft. 1655 . . . . . . . . . 101

Reden der gewelddadige havensluiting. . . . . . . . 102

De Pan-Islamietische agitatie . . . . . . . . . . 103

Maatregelen tegen de havensluiting. 1656 . . . . . . 105

$\mathrm{X}$. Het stelsel der vier voorname strandheren.

De opening der havens. 1657 . . . . . . . . . 107

De bestuurshervorming . . . . . . . . . . . . 107

De twee groepen strandheren . . . . . . . . . 109

Tg. Pati en zijn mededinger, ng. Marta-Nata . . . . . 110

Financiële druk op het volk. 1656-59 . . . . . . . 114 
Het monopolie der vier strandheren. 1657 . . . . . . 114

Verboden handel. $1657-58$. . . . . . . . . . 116

Handelsreizen met Westerse hulp. 1657-59 . . . . . 117

Bouw van jachten. 1652-59 . . . . . . . . . . 119

Belangengemeenschap met de Makassaren. 1659 . . . . 120

Gezamenlijke paardenaankopen. $1657-58$. . . . . 121

De bijzondere geschenken. 1656-59 . . . . . . . 123

Gemeenschappelijke geldnood. 1659 . . . . . . . . 125

De kwestie der tollen. . . . . . . . . . . . . . . . . . 127

Bedreiging met ontruiming. 1659 . . . . . . . . . . . 128

De dood van ng. Wangsa-Radja. 1659 . . . . . . . . 130

De Nederlanders onder druk gezet. 1659 . . . . . . . 131

Indruk van Palembang's verwoesting . . . . . . . . 132

XI. Het tweede conflict.

De havens andermaal gesloten. 1660 . . . . . . . 134

De verantwoordelijkheid voor de havensluiting . . . . 135

Contactpogingen. 1660 . . . . . . . . . . . . 136

De val van tg. Pati. 1659 . . . . . . . . . . . 136

Tg. Pați wordt tg. Sura-Baja. 1660 . . . . . . . . 138

Evert Michielsen in Sura-Baja. 1660 . . . . . . . . 139

De dood van tg. Sura-Baja. dec. 1660 . . . . . . . . 141

De val van tg. Sura-Nata van Demak. 1661 . . . . . 142

Glorie van ng. Marta-Nata. 1659-61 . . . . . . . 143

De kolonisatie in West-Java. $1660-61$. . . . . . . . 144

$\mathrm{Ng}$. Marta-Nata laat paarden kopen. 1662 . . . . . . . 145

Ng. Marta-Nata wijzigt het Tjerebonse bestuur. Eind 1662147

De dood van ng. Marta-Nata. dec. 1662 . . . . . . 148

XII. Het herstel der loge.

Het weder openen der havens. 1661 . . . . . . . . 150

De terugkeer der Nederlanders in Japara. 1661-63 . . 151

Het aandringen op een ambassade. $1661-63$. . . . . 154

Onbehagen na de mislukking. $1663-64$. . . . . . . 156

Residenten. 1661-66 . . . . . . . . . . . . . 157

Het bewind van Tanu-Menggala. 1663 . . . . . . . . 159

De opkomst der regerende kooplieden. 1665-67 . . . 160

XIII. Gouverneur kj. Wira-Dika en de kooplieden-regeerders.

Aanstelling van kj. Wira-Dika. febr. 1666 . . . . . . 162

$\mathrm{Kj}$. Wira-Dika's aandringen op een gezantschap. $1666-67 \quad 163$

Het gezantschap van Wagenaar. 1667 . . . . . . . 168

Het aandringen op een nieuw gezantschap. 1668 . . . 174

Het gezantschap van Verspreet. 1668 . . . . . . . 176

Het tweede optreden van Tanu-Menggala-Wangsa-

Dipa. 1668-69 . . . . . . . . . . . . . . . 180

Het gezantschap van De Jongh afgewezen. 1669 . . . 181 
Indruk van Makassar's verovering. 1669 . . . . . . 185

Ng. Wira-Dikara's misnoegen. 1669 . . . . . . . . 186

Ng. Wira-Dikara's val en dood. 1670-72 . . . . . . 188

Laatste aandringen op een gezantschap. 1670 . . . . . 189

De residenten na 1666 . . . . . . . . . . . . . 190

XIV. De sjabandar Wira-Atmaka en de landregenten.

Kj. Wira-Atmaka's ambt . . . . . . . . . . . 192

De landregenten of umbuls . . . . . . . . . . . 193

De umbuls elders . . . . . . . . . . . . . . . 194

Kj. Wira-Atmaka's geldbeheer. 1669-76 . . . . . . 195

Het geval met de Engelse „Zante”. 1673-74 . . . . 197

De kwestie Imbassadana. 1672-75 . . . . . . . . 199

Kj. Wira-Atmaka's wanbeheer . . . . . . . . . 201

Kj. Wira-Atmaka's hofreizen . . . . . . . . . . 203

Kj. Wira-Atmaka's zonen . . . . . . . . . . . 206

Samenvatting . . . . . . . . . . . . . . . 207

\section{AFKORTINGEN.}
ad. adipati
nj. njai
dip. dipati
pan. panembahan
G.G. Gouverneur-Generaal
pg. pangéran
kdj. kangdjeng
rd. radèn
kj. kjai
rg. rangga
ng. ngabéhi
tg. tumenggung 
I.

\title{
JEUGD EN REGERINGSAANVAARDING VAN SUNAN MANGKU-RAT TEGAL-WANGI.
}

\author{
Geboorte en naamgeving.
}

De Susuhunan van Mataram, bekend als Mangku-Rat Tegal-Wangi, was niet het oudste kind van zijn vader sultan Agung, doch het tiende. $\mathrm{Hij}$ was echter het tweede kind der tweede officiële gemalin, rd. aju Wetan. De eerste heette kdj. ratu Kulon, volgens een handschrift op het Kon. Instituut: ratu mas Tinumpak. $\mathrm{Zij}$ werd echter na de geboorte van haar zoon, rd. mas Sahwawrat om onbekende reden verstoten. De tweede zal daarop in haar plaats getreden zijn.

Terwijl de afkomst van de eerste gemalin onvermeld bleef, is die van de tweede bekend. $\mathrm{Zij}$ heet een putri, dus een prinses, uit Batang. Elders bespraken wij het bezwaar, dat zij bij Van Goens als een Tjerebonse prinses gedoodverfd staat (v. Goens 60 en 240 ). Wij zochten de oplossing daarin, dat zij wel uit Tjerebon geboortig was, maar naar een apanage in Batang genoemd werd. Na het verdwijnen der eerste vrouw zal zij haar naamtitel van rd. aju Wetan voor die van kdj. ratu Kulon verwisseld hebben. $\mathrm{Zij}$ overleefde haar echtgenoot en stierf A. J. 1575 (begin: 2 dec. 1652).

Haar oudste zoon werd omstreeks 1619 geboren, Aanvankelijk droeg deze de naam van rd. mas Sajidin, een Arabische dus. Vervolgens heette hij Djibus (beslapen), daarna Rangkah (doornhaag, grensafsluiting). Als kroonprins werd hij officieel pg. arja Mataram genoemd. Lang na zijn dood, wel niet vóór de 18e eeuw, verschijnt hij als Mangku-Rat, gelijk zijn zoon zich dadelijk bij zijn regeringsaanvaarding noemde. Ter onderscheiding van de latere Mangku-Rat's heeft hij de toevoeging van Tegal-Arum (naar zijn begraafplaats) of Agung (groot).

De tweede zoon der ratu Kulon wordt in overlevering en Sadjarah Dalem rd. mas Alit (klein) genoemd, maar Van Goens kent een naam, die juist het omgekeerde betekent, n.l. rd. Agong (v. Goens 246). Deze werd ter opvoeding aan de rijksbestuurder tg. Danu-Paja toevertrouwd,

Verh. dl. 33 
welke volgens Van Goens vermoedelijk ten onrechte ook de opvoeder van de kroonprins zou geweest zijn. Sedert staat hij soms als pg. Danu-Paja bekend. De Babad Sengkala geeft als zijn geboortejaar A. J. 1553 (A. D. 1631) op, hetgeen vrij laat lijkt.

\section{Jeugdjaren.}

Voor de jeugd van de kroonprins verwijs ik kortheidshalve naar hetgeen daarover in „Sultan Agung” (p. 247-53) geschreven werd, hoewel ik op een enkel punt meen te moeten afwijken. Zo werd de kroonprins van zijn 5e tot zijn 15e jaar, dus van 1624 tot 1634, opgevoed door de oude tg. Mataram, met wie Van Goens nog in 1649 kennis maakte. Deze is zeker niet te vereenzelvigen met tg. Danu-Paja, pg. Alit's leermeester, hoewel Van Goens de tg. Mataram ,hun beijder leermeester" noemt, wellicht omdat deze van 1629 tot 1637 óók tg. Mataram is geweest. Bovendien schijnen gevangen Nederlanders, die bij de prins in dienst waren getreden (of genomen), invloed op de jongeling te hebben uitgeoefend.

Nadat hij tot rijpheid was gekomen, liet sultan Agung de kroonprins in 1643 huwen met een dochter van pg. Pekik, zeer waarschijnlijk niet uit diens huwelijk met Agung's jongere zuster, ratu Panḍan Sari (Sultan Agung 212). Aldus werden de Mataramse en Sura-Bajase vorstenhuizen verbonden. Het eerste kind uit dit huwelijk moet spoedig gestorven zijn; het tweede was de latere sunan Mangku-Rat II. Veertig dagen na diens geboorte overleed de moeder.

In 1637 werd de kroonprins het middelpunt van een ernstige hofintrige. Tg. Danu-Paja en tg. Sura-Agul-Agul, die in 1629 Batavia belegerd had, waren hierbij betrokken. Volgens Antonie Paulo, de leider der Nederlandse krijgsgevangenen, zou er overspel gepleegd zijn. Van Goens noemt in dit verband de kroonprins, die de liefste vrouw van tg. Wira-Guna zou geschaakt hebben. Voorstanders van zijn jongere broeder pg. Alit, tot welke zeker tg. Danu-Paja zal behoord hebben, hadden het bij de Vorst aangegeven, in de hoop dat de kroonprins van zijn rechten vervallen verklaard zou worden en vervangen door pg. Alit. Vergeefs! De Sunan berispte beide partijen, doch handhaafde de kroonprins, hoewel deze enige tijd uit de Kraton werd gebannen. Hij stelde zich weer onder de leiding van zijn leermeester, dus de oude tg. Mataram. Tg. Wira-Guna, die in drift zijn door de kroonprins teruggezonden vrouw gekrist had, kreeg van de Vorst een ernstige waarschuwing, doch geen straf. 
Volgens berichten der krijgsgevangenen werd de zaak ernstiger behandeld. Twintig leden van 's prinsen hofhouding - medeplichtig aan de schaking? - werden gedood. Tg. Danu-Paja werd tot een zware boete veroordeeld, evenals, om ons onbekende redenen, tg. Sura-AgulAgul. Deze laatste moest zich bovendien voor Batavia gaan doodvechten, hetgeen hij ook deed.

\section{Verheffing.}

$\mathrm{Na}$ de dramatische gebeurtenissen van 1637 bleef de kroonprins in de schaduw tot aan zijn plechtige troonsbestijging in 1646. Hierover bezit men late Javaanse berichten uit de overlevering en een vroeg Nederlands bericht bij Van Goens, dat natuurlijk toch weer op een Javaanse zegsman teruggaat. In zijn Corte Beschrijvinge (v. Goens 199) deelt onze gezant het volgende mede:

Vijf jaar na het herstel van de kroonprins aan het hof in 1640 overleed sultan Agung. Eer hij het tijdelijke met het eeuwige verwisselde, regelde hij de opvolging. „Dese successie geschiedde gedurende des vaders sieckte", verzekert Van Goens, terwijl hij in de Reijsbeschijvinge (v. Goens 244) vaststelt, dat hij „,deesen jongen soone... met sonderlinge voorsichticheijt ende bestier, selffs van Wiera Gouna in 't Javaense rijck heeft doen bevestigen". De Nederlander prijst dus 's Vorsten vooruitziende blik, die hem tg. Wira-Guna voor een vlot verloop der erfopvolging deed inschakelen. Agung duchtte n.l. twist tussen de beide prinsen gebroeders en hun oom pg. Purbaja, „zijn eijgen oudsten broeder". Dus ontbood hij zijn voornaamste groten, onder wie een ongenoemde pangéran en tg. Wira-Guna de voornaamste waren, zo mede pg. Purbaja. Dezen liet hij de aanstelling van zijn oudste zoon goedkeuren, hield hen tevens enige dagen aan het hof, opdat zij niet zouden wegtrekken en oproer maken. Onderwijl werden alle tolpoorten met krijgsvolk bezet en het grootste deel van het leger onder tg. WiraGuna onder de wapenen geroepen. Deze bewaakte ook al het geschut en het arsenaal ten bate van de jonge koning.

Dadelijk na Agung's dood vertoonde zich de nieuwe Vorst met zijns vaders lijfwacht op de gewone audiëntieplaats, dus wel de sitinggil, waar alle groten hem met ,slaeffsche dienstbaerheijd" geluk wensten. Hij aanvaardde er de naam van Susuhunan Ingalaga Mataram.

Daarop droeg hem pg. Purbaja zijn kinderen en kleinkinderen op, die hij hem als na verwante dienaren hogelijk aanbeval. Zelfs nam hij de vrijheid te verzoeken, toch zijn ,oudere” broeder niet te verwerpen, 
doch zich aan zijn vader te bespiegelen. Deze had hem, Purbaja, ofschoon de oudere, toch steeds hartelijk bemind en zelfs bevorderd. Onder de indruk dezer woorden werd de broeder, die afwezig was - geen gunstig teken! - ontboden en vermaand, in zijns ooms voetstappen te treden, die, hoewel ouder van jaren, toch beider vader boven anderen geëerd en met raad gediend had.

Nadat dit geregeld was, naderden alle groten, niemand uitgezonderd, de nieuwe Vorst al kruipende, om zijn voet te kussen. Evenwel eiste de Sunan dit eerbetoon niet van zijn oom of broeder. Achtte hij hen tot deze vernedering niet bereid? Daarop volgde een vorstelijke toespraak tot de oude raadgevers zijns vaders, die hij meer dan anderen beloofde te eren. Ten slotte verhief hij enige groten, onder wie tg. Wira-Guna, tot hoger rang. Daarna pas konden de tolpoorten weer geopend worden en werd zijn vader met omvangrijke ceremoniën ter aarde besteld.

Dit alles ziet er niet onaannemelijk uit. Wij herkennen tal van Javaanse karaktertrekken. Dat Agung nog kort voor zijn dood de erfopvolging in het bijzijn zijner groten regelde, pleit voor zijn wijsheid, die hem zelden in de steek liet. Dat verdachte aanzienlijken belet werd het hof te verlaten, is een maatregel, die later meermalen zal worden getroffen. Tg. Wira-Guna's functie wordt goed weergegeven: hij was een machtig legeraanvoerder. Met een troonsbestijging gaat een naamsaanvaarding evenzeer gepaard als een promotie van prinsen. Het nederig huldebetoon der groten wordt later herhaaldelijk aangetroffen (v. Goens 200 noot 1 en 2 ).

Thans dient een en ander medegedeeld te worden over de groten, die volgens Van Goens getuigen waren van de troonsbestijging, t.w. tg. Wira-Guna en pg. Purbaja.

\section{Tg. Wira-Guna.}

Gelijk wij reeds in „Sultan Agung” zagen, bekleedde tg. Wira-Guna gedurende de laatste levensjaren van deze vorst een hoge positie, doch waarschijnlijk niet die van tg. Mataram. Sedert 1644 komt hij regelmatig in de brieven der Hoge Regering voor, die aangenaam contact met hem heeft.

Mogelijk maakt een document, reeds in 1869 door $K$. F. Holle in het Tijdschrift van het Bataviaasch Genootschap gepubliceerd, een einde aan de onzekerheid omtrent tg. Wira-Guna's positie ten hove.

Dit stuk, een door sultan Agung verleende piagem, bevond zich in handen van de regent van Suka-Pura. Bij deze acte stelde de vorst 
de eerste regenten van Bandung, Parakan Muntjang en Suka-Pura aan onder de titel van hoofdmantri's, omdat zij hem tijdens de opstand van Ukur en Sumeḍang trouw gebleven waren. Daarbij bevrijdde hij hen „van diensten te presteren aan de groten van Mataram (zoo als daar) te boek gesteld zijn: de paněmbahan van Cheribon, de pangeran van Kadjoran, de pangeran van Blitar, de pangeran van Madiun, de panĕmbahan van Sura-Baja, de vier patih's van Mataram: de tumenggung Wira-Guna, de tumenggung Tanpasisingan, de tumenggung $\mathrm{Sa}$ loran en de tumenggung Singa-Ranu."

Ofschoon deze oorkonde gedateerd is op de 9e van de maand $\mathrm{Mu}$ haram van het jaar Alip (20 april 1641), stelt zij mogelijk een wat jongere toestand voor, daar destijds de Mataramse vorst nog Susuhunan was. Ook staat vast, dat in het begin van $1642 \mathrm{kj}$. ng. Dirantaka nog het ambt van tg. Mataram bekleedde (d. J. V., 258, noot 3), zodat er van een viermanschap nog geen sprake kon zijn. Daarom zullen wij ons deze vier patih's enige tijd ná ng. Dirantaka's heengaan kunnen voorstellen, hetgeen in de loop van 1642 kan hebben plaats gevonden, daar in 1643 tg. Wira-Guna van zich laat spreken. Dit viertal kan dan tijdens de laatste jaren van de zieker en zwakker wordende vorst het bewind gevoerd hebben, waarbij tg. Wira-Guna het meest op de voorgrond trad. In dit opzicht stemt hij overeen met de latere gouverneur van Japara, ng. Marta-Nata, die ook lid van een viertal was, doch zich op den duur boven de andere drie wist te verheffen. Het is daarom geen wonder, dat deze in 1661 een tweede tg. Wira-Guna genoemd wordt. (D. 25 nov. 1661).

Dat men deze krachtige figuur niet alléén met het ambt van tg. Mataram belastte kan voortspruiten uit zekere beduchtheid voor zijn eerzucht. Vandaar, dat hij drie ambtgenoten naast zich kreeg. Doch daar hij in de opsomming op de piagem het eerst vermeld wordt, was hij misschien primus inter pares.

\section{Pg. Purbaja.}

Wat pg. Purbaja betreft, volgens de Javaanse overlevering heeft een grote van die naam deel genomen aan de belegeringen van Batavia in 1628-29; ten slotte is hij gesneuveld in de slag bij Gegodog op 13 oct. 1676 als een hoogbejaard man, die drie generaties Mataramse vorsten gediend had. Is dit dezelfde, die behalve de overlevering ook Van Goens vermeldt als oudere broeder van Sultan Agung, aanwezig bij de troonsbestijging van diens zoon? 
In 1668, 14 jaar na Van Goens' laatste bezoek aan het hof, wordt een pg. Purbaja door de scherp opmerkende Nederlandse gezant $\mathrm{Abr}$. Verspreet, die in october van dat jaar de Kraton bezocht, de oudoom van de kroonprins genoemd, m.a.w. de oom van de Sunan en de broeder van sultan Agung (d. J. VI, 179).

Toen „den ouden pangeran Pourbaya” 8 jaar later tegen rd. TrunaDjaja en zijn Makassaren gesneuveld was, werd hij door pg. Adipati Anom enige malen met oom aangeduid, n.l. in een brief aan de sjabandar O. Ockersen (D. 5 nov. 1676); doch in een schrijven aan de G. G. noemt hij hem „syn outste oom pangeran Pourbaya” (D. 7 nov. 1676). Is dit een poging om het Javaanse embah uwak of embah paman te vertalen?

Daar overigens nergens tussen 1646 en 1676 sprake is van de dood van een pg. Purbaja - en hij komt vaak genoeg voor - kunnen wij gerust aannemen, dat alle pg. Purbaja's, die in dat tijdvak optreden, identiek zijn, n.l. de oom van de Susuhunan, later bekend als MangkuRat I.

Thans rijst de vraag, of déze Purbaja, die wij van 1646 tot 1676 als broeder van sultan Agung kennen, tevens de aanvoerder is, die in 1629 Batavia hielp belegeren. De brief der Hoge Regering van 15 dec. 1629 spreekt van "Quiay du pati Inprobaya, neve van de Mattaram", dus: kj. dipati ing Purbaja. Afgezien daarvan, dat het woord neef in het Nederlands reeds een niet scherp omschreven betekenis heeft, verwisselen Nederlanders wel eens meer Indonesische verwantschapsnamen. Met dit neef kan dus zeer goed een halfbroeder van lagere rang bedoeld zijn, gelijk de pg. Purbaja van 1646 tot1676 van sultan Agung was. Dit maakt het waarschijnlijk, dat de Purbaja van 1629 gelijk is aan die van 1676 en de Javaanse overlevering dus gelijk heeft.

Ten slotte dienen wij na te gaan, welke plaats deze pg. Purbaja inneemt tussen de anderen van die naam. In de Sadjarah Dalem vinden wij er voor de $17 \mathrm{e}$ eeuw niet minder dan vier genoemd.

In generatie 132 no. 6 wordt vermeld:

10 rd. mas Damar, later pg. ad. Purbaja (I), zoon van Sénapati en een bijvrouw uit Giring. Bij Agung's verheffing (tot susuhunan in 1624?) werd hij tot panembahan verheven.

In generatie 133 worden geen Purbaja's vermeld, maar in generatie 134 no. 9 komen voor:

20 pan. Purbaja II's dood tijdens sunan Mangku-Rat I;

30 rd. mas Sahwawrat, later pg. tg. Padjang, zoon van sultan Agung en kdj. ratu Kulon, die verbannen werd. $\mathrm{Na}$ de dood van pan. 
Purbaja II (zie sub $2^{\circ}$ ) werd hij diens plaastvervanger en kreeg de de naam pan. Purbaja III. Hij overleed echter spoedig.

$4^{0}$ pg. tg. Mataram, zoon van pan. Purbaja II en na de dood van pan. Purbaja III diens opvolger. ${ }^{1}$

De anders zo volledige Sadjarah Dalem verzuimt in generatie 133 de daar te verwachten afstamming van pan. Purbaja II te melden. Daar slechts zijn dood onder sunan Mangku-Rat I verhaald wordt en tijdens diens regering slechts één Purbaja stierf, n.l. in de slag bij Gegodog op 13 oct. 1676, moet deze pan. Purbaja gelijk zijn met de in overlevering en Compagniesstukken voorkomende broeder van sultan Agung en zoon van pan. Krapjak. In dat geval zouden de eerste drie Mataramse vorsten allen een Purbaja tot zoon hebben, hetgeen zeer redelijk lijkt.

Wij zullen zien, dat er een groot onderscheid bestaat tussen de Javaanse voorstelling van deze pan. Purbaja II in de overlevering, en de feiten, welke wij omtrent zijn gedrag uit het Compagniesarchief kennen. Bijna steeds heeft hij tot de oppositie behoord, terwijl de overlevering hem tot in de wolken verheft als trouwe verdediger en beschermer van zijn vorstelijke neef. $\mathrm{Hij}$ is het, die deze op de dampar, op de sitinggil doet plaats nemen en tot Vorst uitroept onder de roemruchte titel van: Zijne Hoogheid susuhunan Mangku-Rat Sénapati-ingAlaga Ngabdur Rahman Sajidin Panatagama, welke titel echter gekopieerd is naar die der latere vorsten (Babad Meinsma 146).

Volgens de Serat Kanḍa (p. 929-30) neemt pg. Purbaja eerst zelf plaats op de vorstelijke stoel en daagt iedereen uit de successie te betwisten. Nadat niemand gereageerd heeft, daalt pg. Purbaja van de troon af, plaatst er pg. Adipati van Mataram op, die hij tot „Soesoehoenan Amangcoerat van Mataram" verheft. Daarna gaat hij nederig op de grond zitten. Allen verbazen zich over deze trouw. Rijksgroten en heilige Priesters storten hun gebeden en wensen uit.

Daarop de gebruikelijke mededelingen over de klimmende welvaart des rijks, het rechtvaardige bestuur en de onveranderlijkheid der overheidsmaatregelen, die bleven zoals ze waren tijdens 's Vorsten overleden vader.

Waarschijnlijk is het zitten op en daarna verlaten van de troon een poging om pg. Purbaja's loyaliteit nog scherper te doen uitkomen. Overigens draagt de overgeleverde beschrijving een te traditioneel karakter, zodat Van Goens's voorstelling de voorkeur verdient.

1 Is dit de in de Dagregisters meermalen voorkomende tg. of pg. Purbaja, die zich aan pg. Puger's zijde tegen diens broeder Mangku-Rat II verzet? 
De vorstelijke titel.

Over de titel, die de Mataramse vorst aannam, werd door mij geschreven in de Bijdragen van het Kon. Instituut (CIX 1953 p. 62 \& vlg.), zodat met een korte uiteenzetting kan worden volstaan.

De jonge vorst noemde zich met de naam, die zijn vader vóór zijn verheffing tot Sultan tussen 1624 en 1641 gedragen heeft, n.l. Susuhunan Ingalaga. Men bedenke hierbij, dat een overerving van de sultanstitel destijds op Java nog niet van zelf sprak. De opvolger van de in 1651 overleden sultan van Bantam moest die titel zelfs opnieuw uit Mekka laten komen, waarna hij Sultan Abulfath Abdulfattah heette. Mogelijk zag de Matarammer tegen de moeite en kosten op, om zich door een buitenlander tot Sultan te laten verheffen, terwijl hij op staande voet en kosteloos zich Susuhunan kon laten noemen. Het droevig einde van het in 1641 terugkerende Arabische gezantschap zal hem evenmin aangemoedigd heben, de relaties met Mekah te hernieuwen, waar deze katastrofe toch ruchtbaar moet zijn geworden. Bovendien zien wij deze vorst naderhand meermalen op kwade voet met de ,geestelijken” staan, zodat ook hieruit een tegenzin tegen al wat Arabisch is kan voortvloeien. Deze terugkeer tot het oude Susuhunan is belangrijk, omdat sedert dien het aanzienlijkste deel der Javaanse vorstennamen Javaans is gebleven, ook al werden er later verschillende Moslimse titels en namen aan toegevoegd.

Thans staat deze vorst als Mangku-Rat bekend, hij die het rijk op zijn schoot draagt. Er bestaat evenwel geen duidelijke aanwijzing, dat hij deze naam ooit bij zijn leven gevoerd heeft. Pas in de Babad Tanah Djawi, die in het derde kwart van de $18 \mathrm{e}$ eeuw zijn definitieve vorm kreeg, wordt hij aldus geheten. Een enkele maal wordt hij evenwel in een Compagnies geschrift kort voor 1700 Susuhunan Amangkurat Sénapati Ingalaga genoemd, terwijl Valentijn verzekert, dat niet alleen zijn thans als Mangku-Rat (II) bekend staande zoon, doch ook hij zelf zich zo liet noemen, „dog zoo doorgaans niet als deze”.

Reeds vrij spoedig na zijn dood wordt deze vorst naar zijn begraafplaats Susuhunan Tegal-Wangi genoemd en nog in een min of meer officiële lijst uit 1743 heet hij aldus. Zelfs de Javanen-kenner Nic. Hartingh kent hem in 1761 slechts onder de naam van Susuhunan Tegal-Wangi of sultan Plèrèd. Pas na het tot stand komen van de huidige Babad Tanah Djawi dringt het Mangku-Rat ook in de buitenwereld door, gecombineerd met Tegal-Wangi of Tegal-Arum. Vaak 
noemt men hem kortweg Tegal-Wangi, evenals men zijn grootvader naar de plaats van diens overlijden Krapjak noemt.

Daarnaast heet hij ook wel eens Mangku-Rat Agung (Sadj. Dalem gen. 134, 10). Daarentegen moeten namen als Ngabdur Rahman Sajidin Panatagama als veel latere toevoegsels beschouwd worden, gebruikt naar analogie van $18 \mathrm{e}$ eeuwse vorstentitels.

Gemakshalve zullen wij van tijd tot tijd de zeer bekende naam TegalWangi gebruiken. 
II.

\title{
DE KRATON PLÈRÈD EN DE VOORNAAMSTE AMBTENAREN.
}

\author{
De Kraton en zijn waterwerken.
}

Kort na zijn regeringsaanvaarding is de Sunan begonnen zijn Kraton van Kerta naar Plèrèd te verplaatsen, welke plaatsen niet ver uiteen liggen. Van Goens kon op één dag de oude en de nieuwe Kraton bezichtigen ( $v$. Goens 63). Voor deze verhuizing geeft de Babad Momana het Javaanse jaar 1570 (begin: 26 jan. 1648). Tijdens het Nederlandse gezantschap in juni 1648 was men met de nieuwe Kraton al aardig opgeschoten. Van Goens onderscheidde toen reeds de ringmuur met de beide ingangen: de meest gebruikte op de noorder aloen-aloen, waar de steekspelen plaats vonden, èn de zuidelijke toegang. De omtrek van de vierkante dalem bedroeg volgens onze gezant 600 roeden of 2256 meter, hetgeen nauwkeurig klopt met de kaart, die later naar de ruines is gemaakt en werd toegevoegd aan het $2 \mathrm{e}$ deel van P. J. F. Louw's Java-oorlog. Een zuider aloen-aloen werd niet vermeld; er zou trouwens ook geen ruimte voor geweest zijn, daar dicht bij de zuideringang de Opak stroomt. Verder blijkt uit het kaartje, dat de dalem niet zuiver een vierkant was, maar een ruit, terwijl de beide binnenpleinen, Kamandungan en Srimenganti, die men moest passeren alvorens de Praba-Jeksa of het eigenlijke vorstenverblijf te bereiken, binnen de ommuring gelegen waren. Daar Jan Vos bij zijn bezoek aan Kerta slechts een Srimenganti kon waarnemen, is tussen dit binnenplein en de aloen-aloen nog de Kamanḍungan ingevoegd.

G. P. Rouffaer, die in 1889 van het Kratonterrein, op grond van de nog zichtbare overblijfselen een schetskaart vervaardigde, welke zich thans in de verzamelingen van het Kon. Instituut bevindt, tekende naast de Srimenganti nog een ommuurd hof, de Sura-Natan, terwijl hij ten westen van de aloen-aloen de moskee schetste.

In zijn Legenda deelt Rouffaer o.a. het volgende mede:

De muren van de Kraton, vóór 1889 met de grond gelijk gemaakt, waren eertijds 5 tot 6 meter hoog en $11 / 2$ meter dik, geheel van baksteen 
opgetrokken, met hier en daar een natuurlijke steen er in gevoegd. Van boven waren zij gedekt met een driehoekig topstuk van uitsluitend witte, naturlijke steen in brede baksteenvorm.

Van hetzelfde materiaal waren blijkbaar de muren van de moskee vervaardigd, wier verloop Rouffaer nog aan de noord- en westzijde duidelijk kon nagaan. Ook telde en tekende hij nog 3 rijen ompak's, voetstukken voor houten kolommen, doch in werkelijkheid moeten het er 6 geweest zijn, zoals ook de oudste beschrijver van deze moskee, C. A. Lons in 1733 vaststelt (B. K. I. III 1855 p. 7-10). Hij zag tevens een surambi.

Dit alles is stellig niet ineens voltooid. Talrijke berichten tonen aan, dat aan de Kraton langdurig gewerkt is. Het eerst wordt de bouw der moskee vermeld, die zowel Babad Sengkala als Babad Momana in het Javaanse jaar 1571 stellen (begin: 15 jan. 1649). Van Goens kon er dus bij zijn eerste bezoek nog niets van zien. In het volgende Javaanse jaar (begin: 4 jan. 1650) werd volgens de Babad Momana het vorstenverblijf, de Praba-Jeksa voltooid. Volgens de Babad Sengkala geschiedde dit pas in het Javaanse jaar 1577 (begin: 11 nov. 1654). Hiermede komen wij dicht in de buurt van een mededeling van de gezant Winrick Kieft. Toen deze op 21 nov. 1655 in de hofstad aankwam, kon tg. Pați hem niet tot de Vorst toelaten. Deze had n.l. ,veel te doen... met sijn vrouwen in ' $t$ maecken van een nieuwe paleijs of te timmeragie" (W. Kieft 396). Enige groten, die niet ,aen sijn werck en hadden gearbeijt, had (hij) ... laten binden en op de paszeeban laten setten in de son te braden". Nogmaals op de $29 \mathrm{e}$ november, verhaalden hem de strandheren, dat de Vorst hem niet kon ontvangen, „,alsoo hij 't te druck heeft met het maken van 't paleijs". Zelfs geen grote mocht hem spreken (Kieft 397).

Blijkens een bericht uit 1659 (D. 13 nov. 1659) was de Kratonmuur 5 vademen hoog en 2 dik. De Sunan beraamde toen deze ,noch met gelycken muer te doen omhalen ende daerboven een borstweringh op te maecken, daertoe veel materialen vereyscht wierden, ende dagelicx over raetslaechden".

In A. J. 1589 (begin: 4 juli 1666) werd de sloping, of volgens de Babad Momana, de brand van de Praba-Jeksa, het vorstelijk woonverblijf, gemeld, waarmede een kort daarop volgende herbouw in verband zal staan.

Intussen was de bouw van andere Kratongedeelten begonnen. Volgens de Babad Sengkala 1572 (begin: 4 jan. 1650), de sitinggil van bakstenen opgetrokken, dus wel de onderbouw. Daarop werden voor de 
sitinggil planken verzameld, ongetwijfeld ter oprichting van een borstwering. In A. J. 1574 (begin: 14 dec. 1651) werd het paviljoen (witana) op de sitinggil verwisseld, dus wel: vernieuwd.

Voorts meldt de Babad Sengkala voor A. J. 1576 (begin: 22 nov. 1653) het stenen halen voor een Keradènan, het kroonprinsenverblijf. De kroonprins heette toen misschien nog radèn mas Kuning. Daar destijds een vrouw voor hem gezocht werd, kwam een eigen woonstede goed van pas. Ten slotte werd in A. J. 1585 (begin: 15 aug. 1662) op het plein Srimenganti een bangsal opgericht.

Volgens de Babad B. P. (X, 42) werd het bevel tot verplaatsing van de Kraton op de eerste grote maandagaudiëntie gegeven, waarbij de Vorst verklaarde, dat de nieuwe Kuṭa van baksteen zou gebouwd worden en Palèrèd heten; daarmede handelde hij in zijns vaders geest. Hiermede stemt de Serat Kanḍa (p. 931) overeen: de Sunan gaf last „om een groote quantiteijt metzelsteenen te bakken... om... een nieuwen hoff op te bouwen op... Plerred". Evenzo de Babad Meinsma (p. 146) : „Gij allen ... vormt baksteenen, want ik wil uit ... Karta wegtrekken... Ik wil een stad bouwen in Plèrèd".

Deze nadrukkelijke vermelding van baksteen zou doen veronderstellen, dat deze grondstof bij de vorige Kraton een minder belangrijke rol speelde, hetgeen Jan Vos' beschrijving uit 1624 ondersteunt. Het feit, dat Karta grotendeels uit hout bestond, kan zijn bijna volledige verdwijning bevordend hebben. Rouffaer en Adam (Djawa X, 150) troffen er nog maar een drietal neuten aan. De kraton Plèrèd daarentegen kon nog in 1826 als een goed verdedigbare vesting dienst doen. Ofschoon hij daarna als materiaal voor de gelijknamige suikerfabriek werd benut, vermocht Rouffaer in 1889 nog duidelijk de gebruikte grondstof te herkennen: baksteen met hier en daar een witte natuursteen.

Niet minder belangrijk dan de gebouwen binnen de ommuring waren de waterwerken daar buiten, die ten dele zelfs aan de stichting van de nieuwe Kraton waren vooraf gegaan. Volgens de Babad Sengkala was reeds in A. J. 1565 (begin: 2 mrt. 1643), dus nog tijdens sultan Agung, met de aanleg van een stuwdam (plèrèd), waaraan de nieuwe Kraton zijn naam zou ontlenen, een begin gemaakt. Raffles' Chronological Table bevestigt dit bericht voor A. J. 1566 (begin: $10 \mathrm{mrt}$. 1644) : An artificial lake made at Plèrèt. Blijkens de Babad Momana is hieraan in A. J. 1574 (begin: 14 dec. 1651) verder gewerkt door de aanleg van een grote dam in de sagara-jasa.

In 1658 werd het werk voortgezet. Zelfs mensen uit het Krawangse 
werden naar Mataram opgeroepen om er te arbeiden, ,sulcx niet hebben connen saeyen noch planten" (D. $14 \mathrm{mrt}$. 1659). Geen wonder, dat er gebrek aan rijst kwam. Het resultaat van hun zwoegen schijnt een uitbreiding van de vijver (het meer) geweest te zijn, daar volgens Dagregister 7 juli 1659 de Susuhunan en zijn gemalin naar de „nieu gegraven viver" waren gereden, die vier dagen later „Segarajasa” wordt genoemd (D.).

In 1661 was de vorst druk bezig ,zyn woonplaets tot een eyland te maken, en daeraen 300.000 man in 't werk hadde" (D. 12 sept. 1661 p. 275). Daardoor konden de strandheren niet afkomen, aangezien zij zonder twijfel daarop toezicht hadden te houden. Hierop slaat ook wel het bericht in de Babad Sengkala A. J. 1683 (begin: 6 sept. 1660) : de bewoners van de Pasisir en de Mantja-Nagara gaan aan het werk en maken weer een dam in Djaha (?). De umbuls moeten ieder voor hun aandeel toezicht houden, maar een bandjir vernielt daarna veel.

Twee jaar later wordt er opnieuw gegraven. De vorst is van plan „een groot water achter of omtrent syn hoff te laaten maken" (D. 28 juli 1663). Enige maanden later heet het, dat de Sunan „syn hooft weer" begon ,te breeken met het maeken van een zeewaeter achter syn hof" (D. 5 sept. 1663). ,'t Is thans in den Mataram stil", meldt het Dagregister van 1 oct. 1663 (p. 466), ,het maken van de zee ofte groote vyver achter het hof van den Sousouhounang, genaemt Segarajasa, is weder by de hand genomen en voltrocken; doch de Sousouhounang heeft ... geen groote lust om sich daerin te vermaken, gelyck hy voor dezen met vaertuygen wel placht te doen". De vijver is dus voltooid. Het laatste bericht over waterwerken bevat de Babad Sengkala A. J. 1589 (begin: 4 juli 1666) meldende, dat de kali Winanga afgedamd wordt.

Wij zien dus, dat sedert het einde van sultan Agung's regering tot het jaar 1666 telkens weer is gearbeid aan vijvers (meren) en dammen bij en rondom de Kraton. Deze dienden deels tot vermaak, deels ter verdediging.

Wanneer de gezant Abraham Verspreet op 16 oct. 1668 het hof bezoekt, passeert hij de brug over de gracht, „die het hoff omtreckt", en bereikt daarna pas de aloen-aloen (K. A. 1158 p. 1441 \& vlg.). De Sunan bewoont dus inderdaad een eiland. Ook bij de volgende Kraton, die van Karta-Sura, is daarnaar gestreefd. Dit opzettelijk isolement strookt geheel met het mensenschuw karakter van sunan Tegal-Wangi.

Niet eenvoudig is het met behulp van deze onvolledige, vage berichten de verschillende dammen en vijvers op de stafkaart terug te vinden. 
Vermoedelijk is men in 1644 reeds begonnen met de aanleg van een stuwdam in de kali Opak, de eigenlijke plèrèd, waardoor een kunstmatig meer ontstond.

Vervolgens werd ter wille van de Kraton-aanleg een dam gelegd, die het water van dit meer binnen de perken hield, maar tevens de Kraton aan zuid- en oostzijde door een inundatie beschermde.

In 1659 werd het meer uitgebreid met een gedeelte ten oosten van de aloen-aloen; daarna werd de oude dam doorgestoken.

In 1661 werd gepoogd het water niet enkel aan zuid- en oostzijde, doch tevens aan de noord- en westkant te brengen. Dit enorme werk vergde 300.000 herendienstplichtigen.

Evenwel in A. J. 1584 (begin: 27 aug. 1661), waarschijnlijk in de westmoeson $1661-62$, vond te middernacht een hevige bandjir plaats. De „Groote Schuur" werd overstroomd, zodat velen gebrek aan rijst kregen. Ook de „Groote Dam” werd weggevaagd. Pas in 1663 werd het werk hervat en tot een goed einde gebracht.

Een bijzonder bouwwerk moet het mausoleum van de ratu Malang op op de gunung Kelir geweest zijn, niet ver van de Kraton gelegen. In A. J. 1588 (begin: 14 juli 1665) stierf deze ratu Mas Malang en werd op de gunung Kelir begraven. Drie jaar later (begin 11 juni 1668) werd daar de Antaka-Pura, haar mausoleum, voltooid.2 Aldus verzekert de Babad Momana.

Dit is het laatste ons bekende bouwwerk van sunan Tegal-Wangi, wie de teugels der regering ontglipten.

\section{De voornaamste hofdienaren: \\ De tumenggung Mataram.}

Als gebruikelijk zal de troonsbestijging van deze Sunan vergezeld zijn gegaan van rangsverhogingen. Dit zou men ten minste kunnen opmaken uit de benamingen, die de Hoge Regering in haar briefwisseling voor tg. Wira-Guna bezigt. Vóór 's Vorsten verheffing heet hij eerste rechter (Bat. 22 mrt. 1645 K. A. 772 p. $141-44 ; 30$ apr. 1646 K. A. 773 p. 145), daarná eerste raad (Bat. 19 juli 1646 d. J. V, 283; Bat. 25 oct. 1646 d. J.V, 295). Al ontbreken ons de Javaanse equivalenten dezer betitelingen, toch mogen wij er wel een titelverhoging in vermoeden.

2 Over dit zeer verwaarloosde graf schreef $\mathrm{L}$. Adam in: Eenige historische en legendarische plaatsnamen in Jogjakarta. Djawa X 1930 p. 154. 
Ook is de bevordering van 's Vorsten vroegere leermeester tot tumenggung Mataram aannemelijk. Dit is de persoon, vermeld in Van Goens' Reijsbeschrijving (v. Goens 242 \& vlg.), ,sijns vaders ende oock zijn groote vrund, daerbij hij als zijn tuchtmeester ende pedagoogh van zijn 5 tot 15 jaren opgevoed was", dus van 1624 tot 1634 . Dit kan echter niet, zoals eerst door mij aangenomen werd, tg. Danu-Paja geweest zijn, die van 1630 tot 1636 tumenggung Mataram is geweest, doch de aldus betitelde grote, die Van Goens in 1648 voor het eerst ontmoette. Tijdens de crisis van 1637 vervoegde de Prins zich opnieuw bij deze oude leermeester, bood hem zijn volk, 12 tot 16.000 man sterk aan, om dezen gezamenlijk te besturen, en ,hielt sich daerenboven meer dan 2 jaeren tot deesen Tommagon, om noch quansuijs te leeren als een kind". Dit is ondenkbaar bij tg. Danu-Paja, die juist in 1636 in ongenade was gevallen en sedert zeker wel tot de oppositie behoord heeft, die het in stilte met pg. Alit, 's Prinsen broeder, hield.

Toen Tegal-Wangi de troon besteeg, zal hij daarom niet tg. DanuPaja, maar zijn oude leermeester tot tumenggung Mataram verheven hebben.

Van Goens ontdekte in deze correcte hoveling ,een gesatich gemoet, gewoon met luijden om te gaen, in wien oock geen (eer) sucht bleeck, maer scheen eerder een arch sachtsinnich man, om de werelt vrij beter als den anderen te gebruijcken" (v. Goens 61). Met die andere bedoelde Van Goens zijn mededinger tg. Wira-Patra.

Ook omgekeerd bestond er waardering. De tumenggung bewees de Nederlandse gezanten „uijtermaten groote vruntschap”; hij ontving Sebalt Wonderaer, ,aen sijn binnenste deur... met omhelsingh, ende leijde hem verder met de hand tot op een alcatijff om neder te sitten, daer al sijn vrouwen ende sijn eijgen slaepplaets was" (v. Goens 55). Verder bewees hij hun ,groote teeckenen van vruntschap, begeerende op de Hollandtsche manier met ons vrolijck te zijn".

Is het te gewaagd om te onderstellen, dat dit alles meer dan de gewone Javaanse hoffelijkheid was, maar dat deze bezadigde hoveling een goede verstandhouding tussen Mataram en Batavia voorstond?

Tot 1651 bleef deze grijsaard de gunst van zijn Vorst genieten, doch kort voor het derde gezantschap van Van Goens, dat in het voorjaar van 1651 naar Mataram trok, bleek hij, met verschillende andere groten, in ongenade te zijn gevallen ( $v$. Goens 80 ). Tevens was hij van al zijn volk, 6000 man sterk, beroofd en ,geoordineert..., sich als een gemeen Edelman met weijnich swiete te erneren".

Enige jaren later is hij blijkbaar overleden, daar de Babad Sengkala 
zijn dood in A. J. 1577 (begin: 11 nov. 1654) stelt. Werd hij te TegalArum bij Tegal begraven, waar de leermeester van de Sunan zou zijn ter aarde besteld? (Babad Meinsma 177).

Mogelijk kwam kj. ng. Wira-Patra in zijn plaats. Hij is de enige, die in de Babad B. P. (X, 70-71) als patih van Mangku-Rat Tegal-Wangi genoemd wordt. Tevens wordt medegedeeld, dat hij een bode (ganḍek) van lage afkomst was, die zeer de gunst van zijn Vorst genoot en daarom tot patih werd gemaakt. Met deze lage afkomst stemt ook Van Goens in, die hem meermalen ontmoette. Tijdens zijn eerste gezantschap had de gezant zich op zijn verzoek naar diens woning begeven, hoewel blijkbaar niet vlug genoeg, zodat hij de Nederlanders „soetelijck” verweet, „hoe wij soo weijgerich waren geweest tot sijnent te comen, daer doch soo dickmael bij den tommagon (Mataram) gingen" (D. 12 juli 1648 p. 114). Hij trachtte dus de oude tg. Mataram opzij te streven. Terwijl de Sunan deze grijsaard vader noemde, betitelde hij ng. WiraPatra met „outsten broeder”. Van Goens kon niet ontkennen, dat „deese queeij wel ten hove staet, mits van geringh tot een groote qualiteyt is gevordert". Bescheidenheid was hem vreemd, „noemende hem selven grooter meester als den ... tommagon (Mataram)". Van Goens kon uit zijn woorden ,geen ofte weijnich verstandt bespeuren".

Dit gemis belette hem niet 's vorsten "grootste minion" te worden (v. Goens 249). Na een nachtelijk feest ten huize van zijn oom pg. Purbaja bracht de Sunan de volgende nacht bij deze gunsteling door (v. Goens 255). Als hij, gelijk Van Goens (p. 249) verzekert, de aartsvijand van den Vorst, tg. Wira-Guna, ,doorsteecken" heeft, moet hij wel sterk in diens gunst gestegen zijn. Ook in de „priestermoord" had hij een belangrijk aandeel. Jammer, dat wij zijn naam voor het laatst reeds in Van Goens' verslag van het 3e gezantschap (1651) ontmoeten. Toen onthaalde hij, mèt andere groten, de Nederlanders op fruit en andere spijzen (v. Goens 83). Toch moet hij daarna nog een bijzondere rol gespeeld hebben; hoe zou de Babad B. P. hem anders als een vooraanstaande figuur kunnen voorstellen? Daar hij in 1648 als mededinger van de tg. Mataram optreedt, zal hij wellicht diens waardigheid verkregen hebben. De Babad B. P. noemt hem ook patih.

Zijn verdwijnen uit de Nederlandse stukken kan samenhangen met een wijziging van het ambt van tumenggung Mataram. In 1648 strekken diens bemoeienissen zich zelfs over zee uit. Hij zendt twee Javanen naar Batavia (v. Goens 48,69); alle zeehavens moeten van hun tollen „reeckeninge aen den tommagon Mataram doen" (v. Goens 71).

In 1651 blijkt dit heel anders te zijn. Er worden twee aanzienlijke 
,Stadthouders over de Noortzyde... (genaemt Wiera ende Wiera d'Iaja)" vermeld. Elders heten ze "Commissarissen" (v. Goens 223), staan over een bijzonder stel ambtenaren "toesienders" (Javaans: tugur), die grote bevoegdheden bezitten. Terwijl het ambtsgebied dezer opperstrandheren ,alle de Noorder-Provintiën" omvat, staan de „vijff binnenlandse Provintiën" onder een „Tommagon", over wie verder niets bekend is. Daarentegen "Crappia ende Mataram selffs" staan onder de tumenggung Mataram, die dus 's Vorsten erflanden: Padjang (Sura-Karta), Mataram (Jogja-Karta) en Krapjak (Bagelèn) beheert.

Ofschoon het ambtsgebied van de tg. Mataram verkleind is, werd zijn taak niet lichter, integendeel! Van Goens (p. 226) acht de „officie van den Tommagon Mataram" de ,allerswaerste bedieninge van 't heele Javaense Rijck". Hij heeft bijna dag noch nacht rust om alle dingen goed te verzorgen en "daervan 's Koninghs curieuse wil te voldoen". Daartoe krijgt hij echter flinke en betrouwbare dienaren als helpers, die bij goed gedrag bevorderd worden. Zijn ambtstijd zou kort zijn; niet langer dan twee jaren. Maar al bekleedde een andere zijn plaats, hij behield toch zijn „,naem ende respect”.

Gezien deze inkrimping van zijn ambtsterrein is het begrijpelijk, dat sedertdien de tumenggungs Mataram veel minder in de Compagnies stukken voorkomen, dan de opperstrandheren, met wie de Nederlanders veel te maken en te stellen hadden.

Deze afzonderlijke regering der stranden is vermoedelijk een tiental jaren voortgezet. Echter is zij niet steeds in handen der opperstrandheren gebleven. Nadat de havens van 1655 tot 1657 gesloten waren geweest, was hun gezag overdragen aan een viertal strandheren, die van Japara en Samarang, die van Pați en Demak. Dit viertal blijft van betekenis tot in 1660 de havens opnieuw gesloten worden en in ieder geval de dienaren der twee opperstrandheren aan de stranden veel te zeggen hebben. $\mathrm{Zij}$ schijnen hun bevelen dan te ontvangen van de tg. Mataram, die een der vroegere opperstrandheren blijkt te zijn.

In Compagnies stukken na 1661 is opnieuw sprake van een „stadhouder in de Mataram", dus tumenggung Mataram, kj. Wira-Djaja, in wie wij een der opperstrandheren, ambtgenoot van $\mathrm{kj}$. Wira herkennen (D. 20 sept. 1661).

Twee jaar te voren blijkt hij reeds een bevel over alle stranden te hebben uitgevaardigd, doch niet duidelijk is, in welke functie. Het kan zelfs zijn, dat hij al in 1657 als tg. Mataram orders gaf (D. 10 nov. 1657 p. $307 ; 4$ dec. 1657 p. 334 ). In elk geval blijkt hij na 1661 veel over

Verh. dl. 33 
de kust te zeggen te hebben, zodat het gezag van de tumenggung Mataram zelfs schijnt te zijn uitgebreid. Evenals in 1648 brengen buitenlandse gezanten - ditmaal uit Palembang - geschenken, zowel voor de Sunan als diens stadhouder (D. 20 apr. 1664). Op sterk aanraden van naar boven ontboden kooplieden bedachten de Nederlandse residenten hem eveneens met een geschenk: reukwerken, „dat wel eenige operatie ten dienste van de Compagnie sal doen" (D. 10 oct. 1665). Voorts had hij met Tjerebon te maken (D. 14 juli 1664) en over Djipang voerde hij zelfs gezag (D. $4 \mathrm{mrt}$. 1666). Al deze bevoegdheden beletten niet, dat hij bij tijden vernederend en openlijk gestraft werd (D. 20 sept. 1661).

Omstreeks 1 apr. 1667 werd deze tg. Mataram met enige andere groten buiten de hofstad in een dorp verbannen (D. 14 apr. 1667). Het bericht van zijn herstel werd niet bevestigd (D. 6 mei 1667). Integendeel, nog voor het jaar om was, bleek hij vervangen. Geen lang leven was hem meer beschoren. Met zijn zoon werd hij in 1670 gekrist (D. 3 juni. 1670).

Op het eind van 1667 is er sprake van de "stadthouder Wiera Carty" (D. 30 oct. 1667), die blijkbaar zeer in de gunst stond, daar hij „rijcx vertrouwde" (Japara 27 juli, 17 aug. 1668 d. J. VI, 175-76), „die Vorst syn naeste persoon" (D. 1 aug. 1668) werd genoemd. Later heette hij meer zakelijk: stadhouder in de stad Mataram of in het hof (D. 20 mei \& 30 aug. 1672). Het laatst komt hij als zodanig in 1673 voor (D. 7 sept. 1673). Maar ook deze vorstendienaar ontloopt zijn noodlot niet. In 1675 heet hij „door ordre van den Coning gecrist en overleden” te zijn (D. 20 apr. 1675).

Reeds vóór dit gewelddadig einde moet hij als tg. Mataram ontslagen zijn, misschien tegen het einde van 1674. Immers in nov. 1674 is er reeds een andere "Mattaramsen stadhouder, keay Soura Wangsa” aan het bewind (D. 6 dec. 1674), wie naar zijn zeggen, de Sunan ,nu eerst het opsicht van sijn pakhuysen heeft gegeven" (D. 30 dec. 1674). De Hoge Regering wenst hem met zijn „nieuwe bedieninge" veel geluk toe; zeker geen overbodige wens (D. 10 jan. 1675). Hij heet ook opziener van des Sunans pakhuizen. Hij schaakt voor zijn meester een vrouw, t.w. de tweede echtgenote van kj. Wira-Atmaka's zoon, kențol DjajaSuta.

Het laatst komt het ambt van tumenggung Mataram, zonder naamsvermelding, voor in Jacob Couper's verslag van zijn gezantschapsreis naar Mataram, onder de datum van 15 mrt. 1677 (d. J. VI, 102).

In ieder geval blijkt uit het bovenstaande summiere overzicht, dat 
aan dit ambt zeker risico verbonden was, hetgeen Van Goens reeds voorzag.

\section{De latere Opperstrandheren.}

Opperstrandheren schijnen ook na het verdwijnen van Wira en WiraDjaja als zodanig niet ontbroken te hebben. In 1676 treden rangga Sidaju en ng. Singa-Wangsa van Pekalongan als heren over de oostelijke en westelijke Pasisir op. Waarschijnlijk zijn zij echter reeds lang in functie, ten minste in 1670 deelt ng. Singa-Wangsa aan de Hoge Regeering mede, dat de Sunan hem ,grootelycx vertrouwt de zeekant te regeren" (D. 31 mei 1670). Daarom informeert hij, onder aanbieding van een geschenk, naar hetgeen met Makassar gebeurd is, „of het seker is, dat het vermeestert zy of niet; en soo 't seker verovert is, op wat dach, maendt ende jaer, en of het met vaertuygen of te lande verwonnen is". Denkelijk is hij met een zelfde ondankbare taak belast als eertijds tg. Pați, die naar de gebeurtenissen bij Palembang een onderzoek moest instellen.

Overigens zijn beide heren eerder bekend. Van ng. Singa-Wangsa, gouverneur van Pekalongan ontvangt de Gouverneur-Generaal op 24 aug. 1666 (D.) 2 paarden, 1 koe, 2 ganzen en 2 pauwen ten geschenke, wellicht bij de aanvaarding zijner functie. Rangga Siḍaju wordt reeds omstreeks aug. 1659 vermeld als opvolger van de vermoorde WangsaRadja van Samarang (Verslag Michielsen).

Is het toeval, dat de Vorst het beheer der stranden aan bestuurders van kleine plaatsen (Pekalongan en Sidaju) toevertrouwt? Het is de vraag, of de kleinheid van hun eigen gebied, niet hun gezag verzwakt heeft. In 1676 blijkt hun taak vooral militair te zijn: zij voeren de vloten der oostelijke en westelijke Pasisir aan.

\section{De bestuursorganisatie volgens Van Goens.}

Een bijzondere beschouwing verdient nog de bestuursinrichting van het Mataramse rijk, zoals Van Goens deze in zijn samenvattende geschriften schetst (v. Goens 222-26).

Het staat wel vast, dat Van Goens, onder de indruk van hetgeen hij tijdens zijn laatste gezantschapsreizen opmerkte, aan deze bestuursinrichting een sterk centraliserend karakter toekende. Hij onderscheidt verschillende corpsen ambtenaren naast elkander.

Vooreerst ziet hij alle Pangérans aan voor subalterne Koningen, hetgeen zij reeds onder sultan Agung niet meer allen waren. Meer en meer 
begon deze titel het voorrecht der prinsen van den bloede te worden. Deze pangérans zouden in de gebieden, naar welke zij genoemd werden, „luijtenanten” gehad hebben, hetgeen voor sommige streken alleszins aannemelijk is. Doch naast deze „luijtenanten" had de Vorst nog stedehouders in deze gebieden. Alleen in de centrale kust-provinciën, Pați en Japara, ontbraken pangérans en hun vertegenwoordigers.

Dan telde elke plaats twee sjabandars of tolmeesters, denkelijk één voor de Inlandse en één voor de Chinese kooplieden, die rekening en verantwoording verschuldigd waren aan de herhaaldelijk vermelde Wira en Wira-Djaja. Bovendien hadden dezen in de provincies nog hun eigen ,toesienders", wellicht de meermalen genoemde tugurs.

Voorts stond er in iedere provincie en stad een commissaris, aan wie de ondergeschikte gouverneurs en sjabandars rekening aflegden over de inkomsten van iedere provincie, stad of dorp.

Naast de burgerlijke, fiscale ambten bestonden er nog militaire, berekend op een leger van niet minder dan 920.000 man, onder welke 115.500 met musketten. Ook hier treden weer commissarissen op.

Ten slotte de ambtenaren van justitie en politie: 4000 onderschouten, staande onder 4 opperschouten ten hove. Eindelijk krioelde het nog van „ontallijcke spions".

Men mag zich vooreerst wel afvragen, of deze ontzaggelijke organisatie op papier inderdaad wel zo uitgebreid was, en voorts, of deze ingewikkelde regeringsmachine zou kunnen werken met de beperkte middelen en vaardigheden, waarover de Javanen toentertijd beschikten. Zelfs een minder alles omvattende apparatuur zou op den duur spaak zijn gelopen. In ieder geval mogen wij achter deze wensdroom - veel meer is het toch zeker niet - een krampachtig streven naar centralisatie onderstellen, dat in de jaren 1653-54 hoogtij vierde; daarna moet enige decentralisatie gevolgd zijn, hetgeen de berichten over de jaren 1657-59 inderdaad bevestigen.

Het ligt voor de hand in deze afwisseling tussen centralisatie en decentralisatie een wedijver te onderstellen tussen de binnenlandse ambtenaren en die uit de Pasisir.

\section{De Rijkstresoriers.}

$\mathrm{Nu}$ doet zich het verschijnsel voor, dat het ambt van tg. Mataram sedert 1663 de indruk maakt van verdubbeld te zijn. Naast tg. WiraDjaja staat nog een „tweede stadhouder” (D. 30 apr. 1663 p. 161). Deze heet „Wiete Nagara”, dat wel tot Niti-Negara verbeterd moet 
worden. Ook deze heeft met de stranden te maken. Zo komt hij in 1664 te Gresik om de regeerders der stranden aan te drijven tot het opbrengen der tollen naar Mataram (D. 28 nov. 1664). Elders wordt hij met tg. Wira-Djaja in één adem genoemd als de twee ,gesaghebbers in den Mattaram", of de twee ,voornaamste van 't ryck" (Japara 8 juni d. J. VI, 173). Beiden zien in gelijke mate de toekomst met zorg te gemoet. Doch terwijl tg. Wira-Djaja reeds in 1667 afgezet werd, blijkt tg. Niti-Negara pas twee jaar later van het staatstoneel verdwenen; zijn zoon wordt dan gekrist (Japara 26 dec. 1669 d. J. V,183-84; D. 21 febr. 1670). Hij overleeft de val van de Kraton in 1677 en heet dan de gewezen eerste schatmeester van de oude Vorst van Mataram (D. 14 oct. 1677). Er is dus een tweede geweest.

Misschien is hij opgevolgd door kj. Niti-Sastra, die in zijn eerste brief aan de Gouverneur-Generaal deze oom noemt (D. 20 apr. 1671). Hij moet dan voor de Sunan allerlei kopen als ,zyde chindes, met eliphanten en tygers beschildert" (D. 29 apr. 1671), doch Maetsuyker bedankt voor de klandizie. In een volgend schrijven, waarbij hij twee gezanten introduceert, noemt hij zich „Keeij Niti Sastra, die opsight heeft over 't pakhuys en alle middelen van den Sousouhounangh en oock in groot gelooff bij hem is, alsmede een deure voor de Mattharams volckeren, om tot den Sousouhounangh te comen" (D. 8 dec. 1671). 3

Van 1672 af blijkt ook zijn functie verdubbeld. In het Japarase schrijven van 28 sept. 1672 komen voor de „Kaijs Niety Sistra en Niety Praija, rijxtresoriers". Hun positie is verre van vast. Volgens de brief uit Japara van 31 jan. 1673 zou de Sunan boos op hen geweest zijn en ze daarom in hechtenis genomen hebben (D. $6 \mathrm{mrt}$. 1673). Enige tijd later zijn ze weer op vrije voeten (Japara 12 sept. 1673). Ze hebben met de middelen van de Chinees Imbassadana nog al wat te maken (D. 7 sept. 1673 en 6 dec. 1674).

Ook de binnenlandse kwesties worden door hen geregeld. Uit naam van de Vorst en op hun last bieden Mataramse groten de 40 achtergebleven weduwen (of dienaressen) van de vermoorde ng. Wira-Dikara aan diens opvolger, de sjabandar ng. Wira-Atmaka aan (K. A. 1180).

In 1675, als er gevaar dreigt, worden hun de voornaamste rijkszaken opgedragen (Jap. 15 aug. 1675 d. J. VI, 193). Zij moeten dan voor de Sunan drie olifanten kopen. Op 13 mrt. 1676 brengen ze een brief van de Sunan in Japara, mar ze zullen wel daarvoor niet alleen gekomen zijn (D. 10 apr. 1676, p. 67). Ook spelen ze bijwijlen een politieke rol,

3 Raadselachtig is de benaming: kj. Niettie Sistra, out gouverneur in Mattaram (Japara 2 dec. 1674 K. A. 1193). 
die blijkbaar orthodox Moslims gekleurd is, b.v. in hun verhouding tot panembahan Giri (D. 14 mei 1676).

Ongetwijfeld hebben ze tot op het einde van sunan Mangku-Rat's regering een groot gezag uitgeoefend. Het laatst zien we hen optreden tijdens Jacob Couper's bezoek aan de Kraton in febr. 1677. Dan verwijt pg. Marta-Sana hun met de penningen te spelen, terwijl de prinsen van den bloede hun leven wagen. Overigens werpt het bericht, dat een lid van het reeds vermelde gezantschap, Santa-Naya genaamd, zich te Batavia schuldig maakte aan het in omloop brengen van „valse dubbelde stuyvers, soo correct nagemaect, dat men se qualyck van de goede can onderscheijden", een eigenaardig licht op hun zakenmoraal (D. 7 jan. 1672). Uit consideratie voor de Sunan werd de schuldige niet gestraft, doch met een boze brief aan de gezant meegegeven.

Het is aannemelijk, dat zij oorspronkelijk hetzelfde ambt bekleedden als de wadana gedong kiwa en tengen, die wij in de 18 e eeuw en daarna ontmoeten. Het is daarom vreemd, dat hun bevoegdheden in de laatste regeringsjaren van Tegal-Wangi zo uitgebreid zijn, welke uitbreiding niet blijvend is geweest. Wellicht poogde deze Sunan door het toekennen aan lagere ambtenaren van bijzondere bevoegdheden, de macht van bepaalde hogere ambtenaren te breidelen.

Bij de behandeling van de macht der strandgouverneurs zullen wij meerdere wijzigingen in het bestuur der stranden ontdekken en wellicht ook in dat van het binnenland. 
III.

\section{EERSTE REGERINGSDADEN.}

\section{De eerste regeringsjaren volgens Van Goens.}

Aan zijn beschrijving der eerste regeringsjaren van Tegal-Wangi laat Van Goens een bespreking van de oorzaak van de haat voorafgaan, die de Sunan tg. Wira-Guna toedroeg (v. Goens 238-44). Daar hierover reeds in "Sultan Agung" en nogmaals korter hiervoor (blz. 5) werd gesproken, kan een herhaling achterwege blijven.

Van Goens deelt mede, dat de Vorst na zijn troonsbestijging tg. Wira-Guna nog hoger verhief en zijn oudere dienaars door jongere verving. De grote man zag hierin een gunst des Konings, terwijl de Sunan inderdaad diens macht ondermijnde, door hem van zijn beste raadslieden te beroven. T'en slotte vond de Vorst in 1647 een goede kans, om zijn lang gekoesterd plan uit te voeren.

Bij een inval van Baliërs in Balambangan waren enige Javanen doodgeslagen. De Sunan, toorn voorwendende, besloot er zelf heen te gaan, doch zijn vertrouwdste dienaren, zijn plan doorziende, bestreden dit en sloegen voor, er tg. Wira-Guna op af te sturen. Deze aanvaardde de benoeming, ,maer quam noijt weeder, alsoo zijn verraders, hem buijten hebbende, omdat hij quansuijs 's Koninghs bevel niet nae de letter uijtvoerde, terstond vermoorden, dat oock onder dit pretext in den Mataram geschiede aen alle zijn geslacht".

Op blzn. 202, 220, 221 en 238 bevestigt Van Goens de moord en op blz. 249 noemt hij zelfs de moordenaar: „Queij Nebeij Wiera Patra, 's Koninghs grootste minion...".

Op deze korte beschrijving van de veldtocht naar de Oosthoek en tg. Wira-Guna's dood volgt een uitbreiding der wraakneming. De Vorst deed zijn „,verdading”, d.w.z. hij diende een aanklacht in wegens het hem tien jaar te voren aangedaan onrecht, en gelastte allen, „die met Wiera Gouna de clachten aen zijn vader weleer gedaen hadden, met wyff ende kinderen als rebellige menschen uijt te roeijen". Het resultaat was, dat ,veel duijsende onnoosele vrouwen ende kinderen ' $t$ leven" lieten. 
Ondertussen „simuleerde den Koninck”, veinsde niet te weten, dat zijn broeder "meede onder den rangh van zijn vijanden" geweest was. Hij deed zelfs erg vriendelijk. De broeder mistrouwde hem echter en, „nu zijn beste vrunden alle meest quijt zijnde, begaff sich tot een nieuwen aenhangh voor hem te vergaderen". Zich bespioneerd wetende, wendde hij zich tot "haer Mahomedaansche paepen, als minst suspect”. Door bemiddeling dezer geestelijken verbond hij zich met enigen „zijner overgebleeven vrunden”, ten einde, naar het gerucht wilde, ",den Koninck in 't tournooijspel" om te brengen.

De Vorst kwam hier achter en besprak het met pg. Purbaja, blijkbaar op zulk een toon, dat de pangéran ontsteld zijn neef verzocht, zich niet aan het bloed van zijn broeder te bezondigen. Dit beloofde hem de Sunan „op zijn trouw met eenige woorden, die onder haer seer heijlich werden gehouden".

Daarop werd de prins door pg. Purbaja bij de Sunan ontboden, en wel met de nadrukkelijkste last, „alle zijn medestanders by namen op te geven, of te hij wilde onschuldig aen zijn dood zijn". Toen de broeder niet alleen weigerde te komen, doch ook zijn medeplichtigen niet wilde verraden, beroofde de Vorst hem van ,alle zijn princelijke waerdichheijt, hem beveelende met niet meer dan 300 mannen tot den Tommagon Mattram, hun beijder leermeester, te gaen leeren wijs worden, sonder tot nader last ooijt buijten des Tommagons huijs te gaen".

Ondertussen ging het onderzoek voort. Enigen van 's prinsen volk werden gegrepen en gemarteld, om de waarheid te vernemen. Om hun kinderen te redden, beschuldigden de ongelukkigen enige ,paepen”, wat hun niet baatte: allen, zuigelingen uitgezonderd, werden gedood, „de rest (vrouwen?) ... onder zijn vrunden verdeelt".

Deze smaad verdroeg de prins niet langer. Met 50 tot 60 van zijn 300 man overgebleven volk besloot hij „,disperaetelijck te sterven". Als tijd koos hij een justitiedag (maandag of donderdag), wanneer de Vorst gehoor gaf en er veel volk op de been was. Te paard reed hij de aloenaloen op, maar op vorstelijk bevel doodden de lijfwachten snel het gevolg van de prins, ontzagen deze; zelfs zijn paard bleef ongekwetst en 20 lijfwachten lieten zich door de lange kris van de prins doorsteken. Ook door de belofte van genade en trouw liet de opgewonden jongeling zich niet bewegen, de strijd te staken. Daarom beval de Sunan diens paard te doden, hetgeen onmiddelijk geschiedde. Toch zette hij te voet zijn poging om zijn broeder te bereiken voort. Het groot getal lijfwachten belette dit, maar hij doorstak een stokoude radèn, door iedereen en zelfs door de Vorst zeer bemind. 
$\mathrm{Nu}$ was het geduld van de Sunan uitgeput. Hij beval zijn mantri's zich niet meer weerloos te laten slachten. „Ick ben onschuldich aen mijn broeders bloed: doet $u(w)$ debvoir hem tot reeden te brengen". Gelukte dit niet, dan liet hij de zaak aan zijn oom over en moest deze beslissen. Daarop trok hij zich in zijn Kraton terug.

De broeder, ofschoon omsingeld, ging door met steken en doodde nóg een grote. Pg. Purbaja, wie dit verdroot, verwittigde hiervan zijn neef. Deze gaf daarop verlof tot zelfverdediging en dadelijk werd de prins doorstoken.

Aldus wordt de dood van des Sunans broeder door de gezant Van Goens beschreven. Zien wij thans, wat de Javaanse overlevering hierover meldt.

\section{De Balambanganse veldtocht volgens de overlevering.}

Daar de Javaanse overlevering geen bijzondere haat van de Sunan tegen tg. Wira-Guna vermeldt en dus evenmin, gelijk Van Goens doet, de oorzaak daarvan behoeft aan te geven, begint het verhaal dadelijk bij de veldtocht tegen Balambangan, die veel uitvoeriger dan in het Nederlandse bericht geschetst wordt: Babad B. P. X, 42-44, Serat Kanda 932-33, Babad Meinsma 147.

Op dezelfde audiëntie, waarop tot de bouw van de nieuwe Kraton besloten wordt, verklaart de Vorst vernomen te hebben, dat de Baliërs Balambangan zijn binnen gevallen. Si Tawang Alun heeft zich aan hen onderworpen. De Serat Kanḍa plaatst deze verklaring tijdens een ander gehoor, waar de Sunan een samenzwering tussen de adipati van Balambangan (dus: si Tawang Alun) en de Baliërs onthult. Eerstgenoemde zou n.l. te voren naar Bali gevlucht zijn.

Daarop stelt de Vorst aan zijn oom, pg. Purbaja voor, om tegen de Baliërs de leiding op zich te nemen. Deze bedankt echter hoffelijk, waarna de vraag volgt, wie dan wel geschikt is; pg. Purbaja ontwijkt een antwoord. Dan richt de Sunan zich tot tg. Wira-Guna en beveelt deze zich gereed te maken, om op te rukken. Tg. Danu-Paja moet hem vergezellen. Tg. Mataram zal alle kustvolken aanvoeren en over zee gaan. Daarop volgt de traditionele beschrijving van de luisterrijke afmars. De Serat Kanḍa voegt er nog aan toe, dat beide veldheren de ,canons van Mattaram" meenemen, terwijl de Babad Meinsma verhaalt, dat de dipati van Sampang soldaten moet leveren.

Daarna volgt in alle babads het verhaal van de opstand en dood van pg. Alit, die wij later zullen bespreken. Vervolgens wordt het verhaal 
van de expeditie naar het Oosten voortgezet: Babad B. P. X, 61-69, Serat Kanḍa 957-962, Babad Meinsma 150 (deze bevat weinig nieuws).

De Babad B. P. vermeldt de aankomst van het leger in het grensgebied Pasuruhan. Behalve de tumenggungs Wira-Guna en Danu-Paja wordt nu ook Asmara-Dana als aanvoerder genoemd. De eerste wil op vrijdag vechten. De Baliërs hebben zich met de Balambangers verenigd. De laatsten staan in de voorste linie en beschermen de Baliërs. Hun aanvoerder is lurah Jabana en Pandji Pati (of volgens de Serat Kanḍa: Pandji Waneng Pati). Tawang-Alun en Wira-Naga bevelen de achterhoede.

Eerst wijken de Matarammers, doch door Wira-Guna's optreden winnen ze weer. Ki Rongga sneuvelt tegen de Bang Wetan; ook Pandji Pati valt. Een hevige strijd ontbrandt tussen Jabana en Tjitra-Juda uit Pana-Raga, welke sneuvelt. Ten slotte vluchten Baliërs en die van Balambangan; Wira-Nagara neemt de wijk naar het noord-oosten.

$\mathrm{Na}$ een nacht van beraad besluiten Tawang-Alun en Wira-Nagara naar Bali over te steken. Het achtergelatene wordt geplunderd. Wel 1500 tjatjah's worden door de Matarammers meegevoerd.

Wira-Guna, de dood van pg. arja Alit vernemende, ontstelt hevig, maar hij verkiest de dood op het slagveld boven terugkeer. Besloten wordt Balambangan tot op Bali te vervolgen. Daarom wordt daarheen overgestoken.

Pandji Arungan verdedigt de kust. Tg. Mataram verschijnt eindelijk met de vloot en een hevige zeeslag volgt. Pandji Arungan sneuvelt en zijn hoofd wordt afgehouwen, zijn schip vermeesterd. Volgens de Babad B. P. zou tg. Wira-Guna aan deze zeegevechten geen deel meer genomen hebben.

$\mathrm{Na}$ de zege wordt tg. Wira-Guna ziek (volgens S. K. 962 ook tg. DanuPaja). De lagere hoofden besluiten daarom terug te keren; de krijgsgevangenen gaan voorop, het leger volgt. Tg. Wira-Guna beveelt zijn familieleden bij mogelijk overlijden, zijn lijk niet naar Mataram te vervoeren, doch ter plaatse te begraven. In Kaḍiri gekomen, neemt hij medicijn in en sterft, door zijn dienaren beweend (Babad B. P. X, 69). Dezen of zijn familieleden (S. K. 962) nemen het lijk toch mee naar Mataram, ofschoon, gedachtig aan zijn opdracht, met tegenzin. Volgens de Babad B. P. X, 69 wordt nu ook tg. Danu-Paja ziek.

De familieleden zenden boden naar Mataram om bericht te geven, doch de Sunan, vertoornd omdat de voortvluchtige Tawang Alun niet opgezocht is, beveelt het hoofd zijner gerechtsdienaars de stoet tegemoet te reizen en het lijk van tg. Wira-Guna, waar het aangetroffen wordt, 
te begraven. Verder moet hij de familie, 12 personen sterk, ook meteen ter dood brengen.

Tg. Danu-Paja, dit horende, neemt vergif in en wordt begraven. Tg. Asmara-Dana, die het gezag waarneemt, wordt na het uitbrengen van een verslag ook gedood (S. K. 965). De Babad B. P. (X, 70) is hierover uitvoeriger. Tg. Asmara-Dana houdt in Tadji stil. Vandaar zendt hij een boodschap naar het hof, doch wordt niet ontboden. Het duurt zo lang, dat de meegebrachte gevangenen moeten gaan bedelen. Eindelijk wordt hij geroepen, maar dan ook terstond gedood. 4

Hiermede eindigt het verhaal van de Balambanganse oorlog, dat wij nog met een enkele mededeling uit een jaartal-Babad kunnen aanvullen. Onder het Javaanse jaar 1568 (begin: 17 febr. 1646) wordt nog vermeld, dat de Sunan na zijn troonsbestijging zich met vrouwen en dienaren te Bangkawa ging verlustigen. Vroeg in de morgen brak hij op, sloeg af, en legerde zich te Djaga-Baja. Toen stelde de tg. Mataram voor om terug te keren, daar er boden uit Bali waren. Dezen waren de zee en de grens van Balambangan overgestoken. Dit korte bericht betreft dus slechts het begin van de strijd.

Thans dienen wij na te gaan, wat de overlevering verhaalt over de onbesuisde aanval van des Sunans broeder op de Kraton.

\section{De aanslag van pg. Alit op de Kraton. 1647.}

Van Goens verklaart, gelijk wij zagen, de aanval van des Sunans broeder op de Kraton uit een verwijdering tussen deze en de kroonprins ontstaan in 1637. De overlevering, dit verhaal missende, wijt de ondoordachte daad van de prins aan opstokerijen van tg. Pasisingan en diens zoon tg. Agra-Juda. Eerstgenoemde was een emban (mentor) van de prins, evenals tg. Danu-Paja, doch deze was naar Balambangan vertrokken, hoewel de prins nog in zijn huis woonde. Tg. Pasisingan en tg. Agra-Juda maakten hem belust op het koningschap en verzekerden, dat half Mataram op zijn hand was. De kans, om zich van het gezag meester te maken was schoon, daar het in de (oude) Kraton erg stil was. Allen waren n.l. bezig een nieuwe te bouwen. Volgens de Serat Kanḍa

4 Op Van Goens' kaart komt als no. 24 voor: Tommagon Asmar Dana. Dit zal dus een plaatsvervanger zijn. Ook vermeldt de Babad Sengkala voor A. J. 1583 (begin: 6 sept. 1660) weer een Semarandana, die gedood wordt, voorover op zijn statiemat liggende, terwijl te Tambak de dood van zijn zoon plaats vond. 
zou tg. Silingsingan, geërgerd over het wantrouwen van de Vorst, er zijn broeder aan herinnerd hebben, dat sultan Agung indertijd te kennen gaf, dat ,Uw ... meede moet genieten de voordelen en inkomsten van Mattaram", hetgeen nu niet het geval was. De goede gelegenheid was er en Silingsingan had reeds ambtgenoten in de arm genomen.

Pg. Alit, pas 19 jaar en nog onrijp, stemde toe een beval zijn volk een aanval op de zuider aloen-aloen te ondernemen. In de Babad B. P. (X, 46) wil de prins nog op zijn emban tg. Danu-Paja wachten, maar tg. Pasisingan duldde geen uitstel. Zijn lurah's ondersteunden hem, zodat de pangéran toegaf.

Tg. Pasisingan stelde de aanslag op de volgende avond, bij het huiswaarts keren der herendienstplichtigen. Dan diende tg. Agra-Juda, op een teken van zijn vader, met gewapenden de aanval vanuit de zuider aloen-aloen in te zetten.

Pg. Purbaja kwam er echter spoedig achter en lichtte de Vorst in, die ontstelde. Hij beval tg. Pasisingan, zodra hij op het werk kwam te doden.

Toen deze de volgende morgen verscheen, werd hij door te voren ingelichte Matarammers op een wenk van pg. Purbaja dood gestoken. Zijn medeplichtigen vluchtten en brachten tg. Agra-Juda op de hoogte. Met de moed der wanhoop schouderde deze zijn piek, steeg te paard en beval zijn rotgezellen hem te volgen. Dezen gingen er echter van door en tg. Agra-Juda moest alleen optrekken. Bij de pangurakan (Babad B. P.: pontjaniti) werd hem de weg versperd en vond hij de dood; zijn hoofd werd afgehouwen. Volgens de Serat Kanḍa lieten de familieleden en onderhorigen hem niet in de steek, doch snelde hij hen allen vooruit, makte amok, werd omsingeld, gedood en onthoofd.

Daarop deelde pg. Purbaja aan de Sunan mede - op de bangsal witana, volgens de Babad B. P. X, 58 - dat Pasisingan en Agra-Juda gedood waren; hun hoofden werden vertoond. Toen de Vorst gehoor verleende en het leger voltallig aanwezig was, ontbood hij zijn broeder door een vrouwelijke bediende, Tadjem. De prins moest n.l. toezicht houden op de Kratonbouw.

Pg. Alit kwam en bij zijn verschijnen, liet de Sunan hem de hoofden zijner vrienden toewerpen met de woorden: „Zo zien zij er uit, die jou tot vorst zouden verheffen". De verbijsterde prins trok zijn kris en ving aan naar de hoofden te steken, terwijl hij tg. Pasisingan de schuld gaf.

De Vorst eiste daarop de uitlevering van al zijn ondergeschikten van de rang van lurah af. Volgens de Babad B. P. (X,52), verklaarde de prins zich hiertoe bereid en beval zijn dienaren, onder welke een achttal lurah's, twee lijfbedienden en een mannelijke talèdèk, zich ter 
uitlevering te laten binden. ${ }^{5}$ De lurah's weenden; zij die op de buitenpasowan waren, sloten zich hierbij aan, ze stookten hun heer op. Deze kreeg medelijden en beval hun, zich te wapenen. Volgens de Serat Kanḍa hoopte de prins nog op een deel van tg. Danu-Paja's volk, maar vergeefs.

De Vorst zond twee boden uit, Sumengit en Daka-Wana. Bij het betreden van de prinselijke dalem werd de eerste .gedood, terwijl de laatste terug vluchtte en verslag uitbracht (Babad B. P. X, 54-56).

Ernstig drukte de Sunan zijn dienaren op het hart zijn broeder, mocht deze aanvallen, te sparen, zelfs ten koste van hun levens. Volgens de Serat Kanḍa (p. 947) keerde hij toen naar zijn paleis terug, doch bij de binnenpoort Sri Menganti gaf hij pg. Purbaja geheime last, om de zaak op het vriendelijkst te schikken. Deze riep daarop alle pradjurits en adipati's te wapen.

Eindelijk verscheen de prins bij de pangurakan met slechts 6 lurah's; de rest was gevlucht. Volgens de Serat Kanḍa was het bij de „groote markt", waar zijn komst grote opschudding verwekte, daar het getal zijner volgelingen niet zo gering was. Toch kostte het weinig moeite met deze grote schare af te rekenen, uitgezonderd 's prinsen naaste volgelingen. Ten slotte sloegen ook deze lurah's op de vlucht, werden achterhaald en afgemaakt. Zo bleef de prins alleen over.

Volgens de Babad B. P. (X, 58) weken alle Matarammers voor hem uit; slechts de dipati van Sampang, demang Melaja, omvatte zijn voeten en poogde aldus zijn stormloop te stuiten. Pg. Alit ontstak in woedde en doorstak de dipati met de kris Sétan Kober in de nek. Uit wraak voor hun heer maakten alle Sampangers, na het wegbrengen van het lijk, amok (S. K. 953). Door vermoeidheid raakte pg. Alit met de befaamde kris zijn dij (of linker arm). Deze lichte wonde deed hem onder de waringin kurung (omheinde waringin) sterven. De dipati's brachten het lijk op de sitinggil, waar zijn moeder haar zoon beweende. Pg. Purbaja troostte haar; pg. Silarong bracht verslag uit (S. K. 955).

$\mathrm{Na}$ een korte rede van de Sunan, die zich in zijn hart verheugde (Babad B. P. X, 60), bracht deze zich een bloedende wonde aan de linkerbovenarm toe; de Madurezen werden allen voor straf gedood. „Het lijk ... wierd op Magierie neevens zijn zalige vader ... begraven” (S. K. 956).

5 De namen der lurah's zijn: Ongga-Patra, Ongga-Pati, Ongga-Juda, PatraJuda, Wongsa-Baja, Astra-Nongga, Astra-Pati, Astra-Wadana, Wira-Lodra. 
Beschouwing over de eerste jaren.

Tussen de beide verhalenreeksen zijn duidelijke verschillen op te merken. Vooreerst valt op, dat die Van Goens veel eerder op schrift gesteld werd, dan die der Javanen. Zij heeft dus meer kans op betrouwbaarheid. Ook beslaat zij een veel langer tijdperk, n.l. van de jeugd van de Sunan tot de dood zijner moeder, dus ruim 20 jaar van omstreeks 1633 tot 1654. De overlevering concentreert zich daarentegen op de gebeurtenissen van 1647-48: de tocht naar Balambangan en de dood van pg. Alit, al behandelt zij deze ook vrij uitvoerig. De voorgeschiedenis blijft, evenals de priestermoord en het Purbaja-probleem, onbehandeld.

De Javaanse overlevering wordt in sterke mate bezield door het streven, om de Sunan te verontschuldigen en te rechtvaardigen. Wellicht is daarom ook de oudere broeder, die bij Van Goens nog pg. Agong heet, tot een pg. Alit geworden, die jonger is. Zelfs overdrijft Van Goens soms, b.v. waar hij, na uiteengezet te hebben, waarom de Sunan zijn opstandige broeder niet levend kon vangen, doch gedwongen was hem te doden, verklaart: ,waeruijt andermael den wreeden ende arroganten aert deser menschen te bespeuren zij" ( $v$. Goens 248). Uiteraard ontbreken bij hem sommige mythische elementen der overlevering, b.v. de zelfverwonding van de Sunan of de toverkris van de prins.

Steun vindt daarentegen Van Goens' verhaal door Nederlandse gegevens. De tocht naar Bali en de dood van tg. Wira-Guna stelt hij in het jaar 1647. Welnu, tijdens het gezantschap van Jan Hermansz (vertrekdatum op of kort na 25 oct. 1646) is tg. Wira-Guna nog in volle fleur en treedt zelfs met overgroot gezag op (v. Goens 62). Doch tijdens het volgende gezantschap van Sebald Wonderaer (Van Goens' eerste ambassade) in het midden van 1648 wordt nog wel over tg. Wira-Guna's euveldaden tijdens het vorige gezantschap afkeurend gesproken, doch de Nederlanders komen hem niet meer tegen. Tg. Mataram, die volgens de overlevering de Balambanganse tocht meemaakte, spreekt men herhaaldelijk (v. Goens 48, 52, 55, 56, 60, 61, 63, $69,71)$. Tg. Wira-Guna zal dus niet meer tot de levenden behoord hebben. Tevens blijkt de Sunan nog een warme belangstelling voor Bali te koesteren.

Van Goens meent niet enkel, dat tg. Wira-Guna vermoord is, doch wijst ook zijn moordenaar aan: tg. Wira-Patra. Dit wordt enigszins ondersteund door het feit, dat in de Babad B.P. X, 71, na het verhaal van de natuurlijke dood van tg. Wira-Guna, onmiddellijk het bericht 
volgt van tg. Wira-Patra's promotie. Eerst was hij slechts een gandek, later bracht hij het tot patih. Ook Van Goens vermeld zijn lage afkomst. Zou deze eerzuchtige zijn bevordering aan een politieke moord te danken hebben?

Terwijl Van Goens' verhaal op redelijke wijze des Sunans gewelddaden tegen zijn broeder en rijksgroten weet te verklaren uit de gebeurtenissen tijdens zijn jeugd, is het betoog der overlevering minder overtuigend, juist omdat het deze jeugdgeschiedenis blijkbaar opzettelijk weglaat. Het conflict tussen de beide broeders wordt uitsluitend uit het stoken van pg. Alit's aanhangers verklaard; de moord op tg. Wira-Guna wordt als een overlijden door ziekte voorgesteld, die op Pasisingan als een zelfmoord. De dood der 12 familieleden en van tg. Asmara-Dana wordt echter niet verklaard. Tekenend is hierbij het optreden van het hoofd der gerechtsdienaars, een aanwijzing voor de ware bedoeling des Sunans.

Toch kunnen wij de overlevering moeilijk missen, doordat zij tal van bijzonderheden bewaard heeft, die Van Goens mist, b.v. dat de aanslag van pg. Alit plaats had tijdens de bouw van de nieuwe Kraton Plèrèd. Dit klopt met Van Goens' mededeling, dat men daarmede tijdens zijn bezoek in 1648 nog bezig was.

Ook het sneuvelen van een Madurese pangéran wordt van andere zijde bevestigd n.l. door de Geschiedenis van het Vorstenhuis van Madoera (T.B.G. XX, 1871 p. 259), waar vermeld wordt dat pg. Tjakra-ning-Rat toezicht hield op het stenen bakken, toen pg. Alit op hem toereed. De Pangéran schrok, liep hem achterna, haalde hem in, greep zijn paard bij de teugel en wilde hem op vriendschappelijk wijze tegenhouden. Maar de Prins was niet te weerhouden, trok zijn kris Sétankober en stak er mede naar de Pangéran. Deze kreeg een heel kleine wond aan het schouderblad, liet zich op de grond vallen en werd (dood) door zijn volgelingen weggedragen. $Z$ ijn zoon, dit vernemende, ijlde naar de aloen-aloen en werd daar handgemeen met de prins, tot zij elkaar met hun krissen overhoop staken.

Daar behalve Tjakra-ning-Rat I, ook zijn zoon rd. arya AtmadjaNagara sneuvelt, zou dit verhaal meer in overeenstemming zijn met Van Goens, die eveneens twee voornamen laat vallen. Verder wordt het graf van deze hoogbejaarde Tjakra-ning-Rat I niet in Madura aangetroffen. Aan het hoofd der praalgraven van Ermata ligt niet hij, doch zijn vrouw de Ratu Ibu begraven.

Trachtende uit alle beschikbare gegevens vast te stellen, wat er nu eigenlijk na Tegal-Wangi's troonsbestijging voorgevallen is, menen wij 
op grond van Van Goens' bericht omtrent de jeugd van de Vorst, diens oude wrok tegen zijn broeder en tg. Wira-Guna te moeten aannemen. De onverwachte aanval der Baliërs in Balambangan bood hem een schone kans om de machtige tumenggung met tg. Danu-Paja naar de Oosthoek te verwijderen.

De aanval van 'sVorsten broeder op de Kraton kan op aanstoken zijner aanhangers, tg. Pasisingan en diens zoon Agra-Juda, geschied zijn. De haat van de Sunan vrezende en de gelegenheid waarnemende, zullen zij de jonge prins op de troon belust hebben gemaakt.

Anderzijds zal de Vorst gestreefd hebben naar de liquidatie ener groep, die hem eertijds had tegengewerkt, en dit mogelijk weer zou doen. Hierbij ging hij bedachtzaam en stelselmatig te werk, pogend zijn broeder tot roekeloosheid te verlokken. Toen deze hiertoe overging, was zijn lot bezegeld. Bij de aanval op de Kraton, met al te weinig volgelingen, vond hij de dood, hetgeen bij een prins van den bloede geen eenvoudige zaak was, De Sunan onttrok zich zo veel mogelijk aan alle aansprakelijkheid voor deze moord op een bloedverwant.

Daarop rekende de Vorst met zijn tegenstanders in het leger af, doch pas nadat Balambangan van vijanden gezuiverd en zelfs een zeeslag tegen Bali gewaagd was. Hieraan vielen tg. Wira-Guna, tg. Danu-Paja en ten slotte ook Asmara-Dana ten offer.

De moord op de "geestelijken".

$\mathrm{Na}$ het verhaal van pg. Alit's dood gaat de overlevering dadelijk over op de geschiedenis van pg. Silarong, terwijl Van Goens (p. 248-50) onmiddellijk daarop de in de Javaanse geschriften ontbrekende priestermoord laat volgen.

Gelijk reeds opgemerkt werd, had pg. Alit volgens Van Goens (p. 245-46) heul gezocht bij „Mahomedaensche paepen”, die hij als boden tussen hem en zijn vrienden gebruikte. Terwijl de Sunan zich tot teken van rouw over zijns broeders dood het haar liet afscheren en enige dagen treurde, was hij steeds bezig "om zijn harsenen te becommeren, hoedanich hij sich mocht wreecken over de paepen", zonder zich te compromitteren. Hij ontbood vier vertrouwelingen, die, ongeveer even oud als hij zelf, hem van jongs af gediend hadden. $\mathrm{Zij}$ waren reeds in de plaats van omgebrachte heren gesteld en hadden veel krijgsvolk onder zich. Het waren:

1e zijn neef „Radin Maes, ende nu Pangeran Aria”. Deze wordt meer- 
malen vermeld, b.v. in 1652, toen hij met een van ,'s Conincx hoochst gelieffde" handtastelijk was geworden bij een hanengevecht (v. Goens 124 ), of wanneer hij met de Vorst in het toernooi wedijverde (v. Goens 229).

2e tg. Nata-Airnawa, die tijdens Van Goens' eerste reis (1684) nog kj. Suta heette, doch in 1649 tot tg. Pați - de naam waarmee hij het vaakst genoemd wordt - verheven wordt. Zie over hem blz. 113-116. 3e tg. Sura-Nata, „nu tommagon Demack”, vrij zeker ten minste sedert 1652 (v. Goens 121). Zie meer over hem blz. 145.

$4 \mathrm{e}$ kj. ng. Wira-Patra, ,'s koninghs grootste minion, die oock Wiera Gouna doorsteecken had", iemand van lage afkomst. Over hem werd reeds gesproken op blz. 33-34.

Deze vier heren kregen de opdracht, zich met hun volk over de vier windstreken te verdelen en er voor te waken, dat „niet een van alles, dat den naem van paep draecht, binnen de geheele jurisdictie van de Mataram hem ontquam". Om dit beter te doen slagen, gaf de Sunan hun bevel, eerst door hun volk te laten vragen, „onder pretext van versoeck", naar hun namen, geslacht en woonplaatsen. Hij achtte dit geschikt, om hen met één slag allen te doden.

De Vorst vertoonde zich intussen niet buiten de Kraton, doch liet de wekelijkse rechtspraak (i.p.v. op de sitinggil?) binnen de muren doorgaan, want daarin placht hij zeer nauwgezet te wezen. Toen hij over alle gegevens beschikte, gaf hij zijn vertrouwden de laatste bevelen, om zeer precies te zijn en mannen, vrouwen noch onschuldige kinderen te sparen. Het sein voor de slachting zou een schot zijn uit het hof (van het grote kanon Sapu Djagad of Pantjawara?). Ook de Sunan wapende zich met goede lijfwachten, aangevoerd door zijn vertrouwdste dienaren. Nauwelijks had het schot weerklonken of binnen een half uur werden 5 tot 6000 zielen ellendig vermoord.

Als wel vaker de verantwoordelijkheid voor zijn gewelddaden schuwende, verscheen hij de volgende dag met een zeer vertoornd en ontsteld gelaat. Hij sprak een uur lang geen woord, hetgeen de schrik deed toenemen. Terwijl niemand dorst ,kicken ofte opsien”, zeide hij tot zijn oom pg. Purbaja: de "papen”, die hen in deugden behoorden voor te gaan, waren de oorzaak van zijns broeders dood. Daarop liet hij door zijn vier vertrouwelingen enige gespaarde slachtoffers naar voren brengen, die prompt toegaven van plan te zijn geweest, om pg. Alit tot vorst te verheffen. In woede uitbarstende liet toen de Sunan 7 tot 8 heren, die hij wantrouwde, wegslepen en afmaken. Hun vrouwen en kinderen werden evenzo terstond gedood. Eindelijk trok hij zich in zijn Kraton 
terug, ,alle de oude heeren, die bij zijns vaders tijt verheeven waeren, in groote last ende becommeringe achterlatende". Aldus berichtte Van Goens in 1656 (p. 249-50).

Doch reeds in 1648 had Van Goens (p. 67) een „vreemde maniere van hunne regeringe" opgemerkt, „mits d'oude vermoort werden, om de jonge plaets in te ruijmen". Zulke onstuimige perioden wisselden echter af met kalmere; na de eerste drie wilde jaren volgden er ten minste vijf, waarin de Vorst zich van een betere zijde liet zien.

\section{Het eerste conflict met pg. Purbaja.}

Thans volgt bij Van Goens een verhaal, dat er, hoewel geheel op zich zelf staande, door zijn Javaans karakter en doordat het goed bij bekende feiten aansluit, toch aannemelijk uitziet.

De hoofdpersoon is de moeder van de Vorst, de Ratu Ibu, die volgens Van Goens tijdens zijn laatste bezoek niet meer in leven was (v. Goens 252). De Babad Momana stelt haar overlijden in A. J. 1575 (begin: 2 dec. 1652).

Van Goens verhaalt, hoe na de laatste moordpartijen van de Sunan, zelfs diens oom pg. Purbaja voor zijn leven begon te vrezen. Zonder kennisgeving bleef hij daarom weg van het hof, hetgeen met muiterij gelijk stond. Onderwijl maakte hij zich heimelijk sterk, daar hij zeer rijk aan volk was en vele aanzienlijke kinderen, kleinkinderen (totaal 50) en vrienden bezat. Zijn zoon rd. Mas behoorde zelfs tot 'sVorsten vertrouwden. Natuurlijk kon de Sunan hiermede geen genoegen nemen; hij duchtte ongeregeldheden. Daarom zond hij de zoon naar de vader terug met de boodschap, ,dat hij (Purbaja) reeden had niet ten hoove te verschijnen, omdat hij (Tegal-Wangi) dit groote werck (de voorafgaande slachting) sonder sijn (Purbaja's) communicatie hadde uijtgevoert". Hij zou hem dus de volgende dag komen bezoeken, om zich te verontschuldigen, en beval de zoon bij zijn vader te blijven, om hem bij het onthaal der gasten te helpen. Maar de zoon, ,die deze taal wel verstont", weigerde. Hij was niet de dienaar van zijn vader, maar van de Sunan, bij wie hij ook wilde leven en sterven. De Vorst beval hem op straffe van zijn toorn te gehoorzamen, beroofde hem van al zijn volk, stuurde hem naar zijn vader en wapende zich met niet minder dan 200.000 man en alle macht van zijn vrienden, om zijn oom Purbaja op te zoeken. Deze grijsaard bezweek niet; hij zond zijn zoon naar de Sunan terug, om hem voor de onverdiende eer te danken. Hij, rd. Mas, 
moest de Vorst blijven dienen, daar het hem, Purbaja, aan geen verstand ontbrak, om zijn heer naar behoren te ontvangen.

Dit was dus een wedstrijd in wederzijdse beleefdheid. Nam de Sunan Purbaja 's voorstel aan, dan betekende dit genade voor deze en zijn zoon. Voldeed echter de oom aan het bevel van zijn neef, dan beduidde dit voor radèn Mas de aanvaarding van het ontslag uit 's Vorsten dienst, met wat er nog meer onaangenaams op zou kunnen volgen.

De koningin-moeder, de strekking van dit gevaarlijke spel doorziende, besloot op te treden. $\mathrm{Zij}$ arrangeerde een ontmoeting tussen de Vorst en zijn oom aan het graf van sultan Agung, en wel in haar tegenwoordigheid. Uitvoerig licht Van Goens toe, hoe zij dit tot stand bracht. Eerst verzocht zij haar zoon vergunning, het graf te mogen bezoeken. Daarna liet zij zich in haar gesloten tandu naar het huis van pg. Purbaja dragen, hem vragende haar te vergezellen. Het was 's Vorsten wil hem bij het graf van de Sultan te ontmoeten. De weifeling van de grijsaard overwon zij door met zelfmoord te dreigen. Daarna drong zij door alle wachten heen tot haar zoon, voor wiens voeten zij zich nederwierp. Toen de ontstelde Sunan haar oprichtte, beweerde zij, dat zijns vaders stem hem naar diens graf riep. Wederom dreigde zij met zelfmoord en trok daartoe haar kleine kris reeds uit de schede. De Sunan, iets vermoedende, liet Purbaja's dalem door diens vijand, pg. Sura-Baja, bewaken en besloot zijn moeder even naar het graf te begeleiden, maar terstond terug te keren. $\mathrm{Z}_{\mathrm{ij}}$ bracht hem bij het graf, terwijl pg. Purbaja op een aangrenzend plein wachtte. Daarop zond zij haar dienstmaagden weg, haar zoon verzoekende met zijn gevolg hetzelfde te doen. 's Vorsten verbazing steeg nog meer, toen zij hem om hals en knieën viel, hem bij de dierbaarste herinneringen zijner eerste jeugd en zijn redding in latere jaren bezwerende een bede in te willigen, die slechts voor hem zelf van nut zou wezen. Na enig tegenstribbelen van de Sunan bekwam zij ,'t jaewoort" en smeekte toen om leven en rang van pg. Purbaja, zich beroepende op het graf en zijns vaders aanbeveling. De Vorst beweerde niet te kunnen; zijn gezag was er mee gemoeid! Daarop zei zij, dat hij dat dan maar eens in werkelijkheid moest tonen, verzocht hem wat te wachten en haalde pg. Purbaja, die nu geheel in de macht van zijn neef was. Beiden stonden verbaasd over hun ontmoeting, doch de pangéran, voor zijn geslacht beducht, vernederde zich, wierp zich ter aarde en kuste 's Vorsten voeten. Ondertussen had de Ratu beider gevolg binnen geroepen, om van Purbaja's onderwerping getuige te zijn. Hierover verheugden zich allen, blijkbaar omdat de Vorst met deze vernedering genoegen nam. Hij vergaf zijn oom diens weerspannigheid 
en zwoer, deze nooit naar het leven te hebben willen staan, doch enkel van zijn gezag beroven. Daarna vond de verzoening plaats en keerde ieder naar zijn hof terug. Met succes was de koningin-moeder, die haar zoon kende, erin geslaagd aan zijn verkeerde neiging een betere wending te geven.

De volgende morgen, toen pg. Purbaja zijn opwachting maakte, was 's Vorsten stemming nog even mild. Hij vergunde zijn oom ten hove te verschijnen, als het hem lustte, terwijl hij de vooruitziende blik zijner moeder, die veel bloedstorting had voorkomen, uitbundig prees. Inderdaad droegen de eerstvolgende jaren zijner regering een vrij vreedzaam karakter.

Als enige bron voor deze verhalen noemt Van Goens de Javanen, die ze hem of zijn tolken verteld zullen hebben. In de Babad ontbreekt het relaas van pg. Purbaja's weerspannigheid en redding. Het zou er ook mee in strijd zijn, daar de overlevering een onwankelbare trouw van pg. Purbaja aan zijn vorstelijke neef onderstelt. De Nederlandse gegevens, te vinden in de Japarase brieven en de uittreksels daarvan in de Dagregisters, zijn daarmede volstrekt in strijd. Als pg. Purbaja's verzet eertijds wel in de rijkskroniek voorkwam, moet het om eerder door mij besproken redenen daaruit zijn verwijderd (Over het ontstaan van de Jav. Rijkskroniek p. 15-16).

Doch pg. Purbaja mocht genade gevonden hebben in het oog van zijn neef, diens voorkeur voor leden der jongere generatie onder zijn hofdienaren verflauwde niet. Volgens Van Goens zou in 1654 (tijdens zijn laatste bezoek) of in 1655 (tijdens dat van Winrick Kieft), ten hove buiten pg. Purbaja en tg. Singa-Ranu niemand van zijns ,,vaders oude raetsheren en groten" meer in leven zijn. Dit is overdreven en men dient ook in aanmerking te nemen, dat het verdwijnen der oudere generatie ook zijn natuurlijke oorzaken kan hebben. In het Javaanse jaar 1575 (begin: 2 dec. 1652) stierf de Ratu Ibu dalem, meldt de Babad Momana, in het Javaanse jaar 1577 (begin: 11 nov. 1654) rd. tumenggung Mataram. Met het verdwijnen der ouderen kon zich 's Vorsten karakter in ongunstige zin ontwikkelen.

\section{Mataram's buitenlandse politiek.}

Over de politieke aspiraties van de Mataramse vorst licht deze zelf ons het beste in. Tegen het einde zijner regering, toen reeds allerwegen kwade voortekenen opdoemden, beschouwde hij zich niet slechts als de bezitter van het „Opperste gesagh... in de stadt Mattaram”, doch ook als een ,gebieder over geheel Java” (D. 4 oct. 1673). Hierbij waren dus 
het reeds verloren Balambangan en het nimmer overheerste Bantam inbegrepen, terwijl het schijngezag over Batavia en Ommelanden ernstig werd opgevat.

Hoe hij over de Overwal dacht, laat zich afleiden uit het schema van bestuursvoering, dat hij in 1657 had vastgesteld. De vier voornaamste strandgouverneurs waren belast met het bewind over Palembang, Djambi, Suka-Dana en ook Batavia. Hierbij zal Suka-Dana wel voor gans Borneo moeten staan, zodat daartoe ook Bandjar-Masin hoorde, dat tijdens zijns vaders bewind hulde had betoond. Doch zelfs de gezant van de vorst van Makassar, waarmede Mataram sedert 1635 in bondgenootschap leefde, wenste de Sunan slechts als de slaaf van een vazal te ontvangen, ofschoon de Makassaar hem toch nooit als meester had erkend.

In 1660 vreesde een strandheer een brief der Hoge Regering in ontvangst te nemen, omdat daarin zijn meester met de sjah van Perzië en de Indische Groot-Mogol alleen maar vergeleken werd.

Ook ter zee waren Mataram's aanspraken onbegrensd. Een Mataramse ondergeschikte gezant meende daarom de pretenties der Compagnie op de zeeheerschappij krachtig te moeten bestrijden (D. 4 dec. 1669).

Wat kwam er intussen van al deze grenzeloze aanmatigingen terecht?

Wat Java betreft: de Compagnie heeft voor het door haar bezette gedeelte n.l. Batavia en omgeving niet meer dan zeker verkapt tribuut betaald, zonder zich daardoor in haar geheel aan de Matarammer ondergeschikt te voelen. $\mathrm{Zij}$ gedroeg zich zeer onafhankelijk en werd dienovereenkomstig ook behandeld.

Bantam, veilig achter Batavia, heeft nimmer Mataram's gezag erkend.

Balambangan moest na één poging om er het gezag te handhaven, weldra worden losgelaten, waarna het òf de prooi der invallende Baliërs, òf weer een zelfstandig rijkje werd, welks vorst zich ook Susuhunan noemde.

Buiten Java bleef uiteraard nog minder van het Mataramse gezag over. Slechts Palembang bleef trouw tot het einde (1677), mogelijk op grond van oude tradities, of omdat het zich bedreigd voelde door Mataram's vijand Bantam en het krachtig groeiende Djambi.

Dit laatste heeft nog de Mataramse vorst gehuldigd, doch spoedig kreeg in dit rijk een krachtige stroming de overhand, die met Java wilde breken, vooral onder de jongere generatie.

Op Borneo is na 1660 niets meer van Matarams gezag te bespeuren, terwijl Makassar de Javanen hoogstens als bondgenoten heeft gewaardeerd. 
Zelfs uit dit beknopte overzicht blijkt, dat er tussen deze aanspraken en de werkelijkheid een kloof gaapte, die met de jaren dieper en breder werd. Laten wij dit proces der rijksontbinding op Java en daar buiten thans wat meer in bijzonderheden nagaan, waarbij wij de verhouding van de Matarammer tot de Compagnie voor een afzonderlijk hoofdstuk bewaren.

Dat dit verval zo snel en krachtig om zich heen heeft kunnen grijpen is wel toe te schrijven aan de geringe krijgshaftigheid van deze vorst, die zeer vaak oorlogsplannen beraamde en meermalen heftig met oorlogsgeweld dreigde, doch zèlden of nooit toesloeg. De Hoge Regering meende in haar generale missive van 16 december 1659 (d. J. VI, 81) hiervan de oorzaak op het spoor te zijn. $\mathrm{Zij}$ geloofde, dat de Susuhunan ter wille van een oorlog ,het Mataramse Hoff niet licht verlaten sal, omdat hy hem buyten hetselve niet verseeckert en hout, nochte dat hy oock aen ymandt van de landtsgrooten de conductie van eenige crygsmacht toe sal vertrouwen om de groote tirannie, die hy... gepleeght heeft, waerdoor hy van ydereen gevreest ende gehaet wort".

Gelijk de opkomst van het Mataramse rijk te danken is aan de sterke karakters van Sénapati en sultan Agung, zo is aan zijn val de wrede aard van hun nazaat, de rampzalige, achterdochtige sunan Tegal-Wangi schuldig.

Thans dient de toenemende vereenzaming van het Mataramse rijk wat meer in bijzonderheden onderzocht te worden. 
IV.

\title{
DE VERHOUDING TOT BANTAM EN BALI.
}

\author{
Bantam - Mataram. 1646-1652.
}

Gedurende de eerste zes jaren zijner regering, heeft de Sunan op kwade voet met Bantam gestaan, natuurlijk om reden van Bantam's geringe onderdanigheid.

Zo lieten de beide sultans van Bantam, de oude en de jonge, in februari 1649 al hun manvolk boven de zeven jaar tellen, ook musketten onder diverse hoofden verdelen. Sommigen meenden, dat „dit tellen geschiede, omme pertinent te connen weten, wat macht tegens den Mattaram, indien (hij) Bantam wilde beoorlogen, souden connen uijtbrengen" (D. 20 febr. 1649).

Omgekeerd wantrouwde de Vorst de Bantammers en vroeg de hem bezoekende Nederlandse gezant, ...fte op Bantam gesanten van Balij gecomen waren" (v. Goens 54). Hij duchtte dus een aanval van weerszijden, daar Bali zijn aartsvijand was. Tevens wenste hij te weten, hoe ver Bantam van Batavia af lag, ,'t welck hem d' Hr. Ontvanger met sijn vinger in 't zant afmaelden" ( $v$. Goens 58-59). Deze dreigende houding deed Bantam inbinden. Er kwam een Bantams gezantschap naar Mataram omstreeks 1648-49. Slechts de Sadjarah Bantěn licht hierover in (p. 58-61 en 186).

Voor de relaties met Bantam gebruikte de Sunan zijn vazal in Tjerebon. Dit was na de dood van de eerwaardige panembahan Ratu in 1640 diens kleinzoon pan. Adining-Kusuma geworden, meest bekend als pan. Giri-Laja. De stokoude pan. Ratu had zijn opvolger ervoor gewaarschuwd, zich niet met een mogelijke onderwerping van Bantam door Mataram te bemoeien. Doch toen hij naar gewoonte zijn opwachting in Mataram ging maken, werd hij door de rijksbestuurder tg. Singa-Ranu dronken gemaakt. In zijn roes beweerde hij, door tg. Singa-Ranu geprikkeld, dat Bantam een tak van Tjerebon was; moest een tak, tenzij afgebroken, de stam niet volgen? „Pangéran, ge zijt wel trouw!" riep tg. Singa-Ranu verheugd uit. Beiden zonden nu gezamenlijk gezanten naar Bantam: tg. Singa-Ranu de mantri's Rudjitnala, 
Djawiring en Sangjang Panengah; de Tjerebonner Satjadimarta. Djawiring zou toen voorgesteld hebben, „dat Mataram en Bantam elke maand elkaar gezantschappen" zouden zenden.

\section{Het eerste Bantams gezantschap. 1650.}

Doch ook al mocht de Sunan iets beweerd hebben over wederzijdse gezantschappen, allereerst zal zijn bedoeling geweest zijn, dat de Bantammer naar Mataram gezanten zond als naar zijn heer.

Het terugkerende Mataramse gezantschap werd dan ook vergezeld door een gelijk getal Bantammers: ki Djamiah, bagus Tjangah, mantri van de Kaneman, ki Tombol en ki Tjilipati. Van mas Dia-ning-Rat kregen ze een brief mede. Te Samarang aangekomen liet Djawiring hen daar achter en reisde zelf door naar Mataram. Na een halve maand wachten werden ze door 100 man afgehaald. Langs de door Van Goens' reisbrieven zo bekende weg trokken ze naar de hofstad, doch bij iedere tolpoort moesten ze een week wachten. Ze logeerden bij de mantri Wira-Karti (de latere tg. Mataram?). Het onthaal was wel goed, maar bedoelde tevens op de Bantammers indruk te maken. Niettegenstaande de vriendelijkheid van hun gastheer, waren ze toch op hun hoede.

$\mathrm{Na}$ een halve maand werden de gezanten met Wira-Karti ontboden door een bode van tg. Singa-Ranu, wiens komst de Bantammers erg aan het schrikken bracht. $\mathrm{Zij}$ bereidden zich al voor op een gezamenlijke dood. $\mathrm{Bij}$ de rijksbestuurder, waar het stampvol zat, was de ontvangst echter minzaam. De gezanten sneden flink op over de grootheid van hun land, de uitgestrektheid van het onderhorige gebied en de talrijkheid der onderdanen. Van Lampung, Tulangbawang en Sulebar tot aan Palembang en Malangkabo kwamen maandelijks bupati's met gevolg, voor het geval er soms oorlog uitbrak.

Tg. Singa-Ranu vond Sura-Sadji (Sura-Sowan: Bantam) een groot land, doch wat dachten de gezanten van Mataram? De gezant ki Mijah achtte Mataram met geen land te vergelijken.

Daarop vroeg tg. Singa-Ranu, wat hij dacht van de woeste tijgers in Mataram, of ze talrijk waren of niet. Ki Mijah gaf toe, dat er in Mataram inderdaad veel tijgers waren, maar bagus Tjanggah merkte op, dat dit van zelf sprak. Mataram was immers een groot land; maar ook in het kleine Bantam waren de tijgers talrijk en woest. Hierop vatte tg. Singa-Ranu vlam en voegde hem heftig toe, dat het volstrekt niet in zijn bedoeling lag, Sura-Sadji gering te schatten. Op deze wijze ging het gesprek voort; geen wilde voor de ander wijken. $\mathrm{Na}$ een onthaal keerden 
de gezanten naar hun verblijf terug. Ze woonden ook nog een zaterdags toernooi bij, waar ze zich over de Mataramse volkrijkheid konden verbazen. Overigens kregen ze de Vorst niet te zien, mogelijk wegens hun lage rang. $\mathrm{Na}$ enige tijd keerden ze naar Bantam terug, waar ze tegen middernacht aankwamen. Dadelijk maakten ze hun opwachting bij de sultan, die over hun lotgevallen reeds een en ander had vernomen en erg benieuwd naar meer was.

Kennelijk heeft het in tg. Singa-Ranu's bedoeling gelegen de Bantamse gezanten, zonder hun de eer van een vorstelijk gehoor te verlenen, bang te maken, hetgeen deels gelukte. Toen ze de volgende dag, in plechtig gehoor ontvangen, geschenken kregen en in rang verhoogd werden - voortaan heetten ze: Karti-Duta, Wangsa-di-Pradja, WiraNaja en Astra-Naja - terwijl ze op lumpings (gedroogde buffelhuiden) mochten zitten, vroeg de sultan aan Astra-Naja, hoe hij het in Mataram gemaakt had. De ondervraagde antwoordde ronduit het gevoel gehad te hebben, alsof hij gefolterd werd, zonder vastgehouden te worden. Veel landen had hij reeds als gezant bezocht, doch nooit één gelijk Mataram (p. 62). Aan Karti-Duta vroeg de sultan, of hij meende, dat de inval der Matarammers in Bantam door zou gaan. Karti-Duta dacht van wel, indien dit gevaar door de zegen van de vorst en die van Sabakingking, begraafplaats van de eerste Bantamse vorst, niet afgewend werd. Daarop trok de sultan zich in zijn Kraton terug.

\section{De Pagarage. 1650.}

Inderdaad vermeldt de Sadjarah Bantěn minstens twee jaren later een poging van Tjerebon om zich van Bantam meester te maken, de Pagarage (S.B. 62-65), welke H. Djajadiningrat in 1650 stelt. Dit wordt ondersteund door een brief van de Hoge Regering, meldende, dat "die van Cheribon op die van Bantam willen oorlogen en rooven" (Bat. 31 juli 1649 K.A. 776 p. 77). In 1649 dreigde dus een oorlog tussen Tjerebon en Bantam, die het volgende jaar kan zijn uitgebroken.

Wij kennen deze Bantams-Mataramse oorlog enkel uit de Sadjarah Bantěn.

In Bantam verschenen twee Tjerebonse gezanten, Djiwa-Sraja en Nala-Wangsa. Toen dezen er niet in slaagden, de Sultan te bepraten, kwamen een santana (verwant van de vorst), pg. Marta-Sari en zijn zoon, met tg. Wira-Tantaha. Ofschoon luisterrijk onthaald, konden zij de Sultan toch niet overhalen, om samen met Tjerebon zijn opwachting in Mataram te gaan maken. „De soeltan van Bantěn wilde geen anderen 
vorst boven zich erkennen dan den soeltan van Mekah, van wien hij vaak brieven met wijze lessen ontving". Onverrichterzake keerde pg. Marta-Sari naar Tjerebon terug, hetgeen de toorn van de Tjerebonner gaande maakt. „Hij schaamde zich zeer tegenover Singaranoe”.

In Bantam maakte men zich geestdriftig voor de strijd gereed, hoewel het aantal krijgers gering was.

Een Tjerebonse vloot van 60 zeilen voer de Tanara op. Sénapati was ng. Pandjang-Djiwa, die pg. Marta-Sari begeleidde. Daarentegen zonden de Bantammers een vloot van 50 schepen onder lurah Astra-Susila, dem. Nara-Paksa en dem. Wira-Paksa. Ook vele andere ponggawa's gingen mede. De sultan loofde 2000 realen en een kampuh (statiekleed) uit voor het welslagen der onderneming. Bij Tanara gekomen stelde Astra-Susila zich verdekt te Tandjung Gede op, de andere twee in de Muara Pasilijan. 's Morgens vroegen roeiden de Tjerebonners de haven van Tanara binnen. Ng. Pandjang-Djiwa wierp zijn wapens weg en gaf zich aan dem. Wira-Paksa over. Hij werd naar de Sultan opgezonden, die hem begenadigde. Toen de overige Tjerebonners de wapens zagen drijven, begrepen ze nog niet, dat Pandjang-Djiwa zich zonder slag of stoot had overgegeven. Ze werden door Astra-Susila en de twee demangs overrompeld. Slechts één schip ontkwam met pg. Marta-Sari; vijftig schepen werden buit gemaakt. De bemanningen verzetten zich niet, werden geboeid en op de vlakte van Sumur Angsana ontscheept. Daar werden ze allen gedood, ofschoon ze om genade smeekten. Hun hoofden werden naar Sura-Sowan (Bantěn) gebracht.

Dit vond plaats op de 30e Ramadhan; op riaja-dag keerden de krijgslieden in Bantam terug. Deze 30e Ramadan viel in het jaar 1650 op 22 december; de riaja-dag op de dag daarna.

De politieke ommekeer. 1652.

Toen Rijklof van Goens in october 1652 aan het Mataramse hof vertoefde, vernam hij, dat de Vorst opnieuw een veldtocht tegen Bantam beraamd had, die gelijk aangenomen kon worden, tegen het midden van dat jaar gesteld was. Reeds was een aanvoerder benoemd, t.w. 's Vorsten oom, pg. Purbaja, die terecht de benoeming slechts aanvaard had, mits men van Batavia's welwillende neutraliteit verzekerd was. Hiervoor had de Sunan echter ingestaan.

Maar plotseling vond een grote verandering plaats, n.l. door toedoen van „papen en ander gespuys”, gelijk Van Goens het uitdrukt (p. 123). Dezen hadden n.l. „nieuwe swarigheyt gepractiseert" door er op te 
wijzen, „, hoe des Conincx vader, stervende als een heyligh man, belast" had: „men soude des Matarams wapenen eerst naer 't Oosten ende dan naer ' $t$ Westen wenden, anders waeren se niet gesegent'. Eerst diende dus Balambangan op de heidense Baliërs heroverd te worden, aleer men zich tegen de Bantamse geloofsgenoten keerde. Het is de herleefde priesterpartij, waartegen de Sunan te voren zo gewoed had, die deze politieke ommekeer voorstond. $\mathrm{Zij}$ beriep zich daarbij op een laatste uitspraak van 's vorsten vader, die reeds in een geur van heiligheid stond.

Aanvankelijk stoorde de Sunan zich niet aan dit islamietische drijven en liet zijn geschut- en geweermakers binnen een kwartaal 800 musketten en flink wat klein ijzeren geschut vervaardigen. Daarop viel een en ander voor, dat hem tot inkeer bracht.

Hij liet n.l. zijn beste, pas voltooide kanon op „syn waerdichste pleyn” (de aloen-aloen?) beproeven; daarop een even groot Nederlands stuk, doch dubbel zo zwaar geladen als het Javaanse. De Sunan verbaasde er zich over, dat dit zo weinig achteruit gesprongen was, en vroeg de Javaanse geschutmaker, of het Javaanse kanon óók zo'n zware lading kon verdragen. Op diens bevestigend antwoord werd het van een dubbele lading voorzien en afgevuurd. Het barstte echter in ontelbare stukken, waarvan het grootste vlak bij de Vorst neerkwam. Deze schrok hevig, liet de geschutmaker gevangen nemen, het plein vervloeken en „voor eeuwigh" toemetselen, ,streckende tot groote discommodatie van syn hoff".

De nacht daarop had de Vorst een akelige droom en binnen weinige dagen was zijn ganse lichaam vol zweren. Dit brak zijn wil; hij werd „religieus”, verzocht de „papen voor hem te bidden”, zwoer, dat hij een oorlog naar het oosten zou ondernemen en beloofde, „hem met den Bantammer te bevredigen, behoudens de reputatie synes persoons".

De priesters zegden toe, voor hem te bidden en genazen hem in tien dagen. Sedert was pg. Purbaja bij zijn neef hoog geacht; hij werd door de Vorst als een heilig man beschouwd. Spoedig zou de oorlog tegen het oosten een aanvang nemen.

Merkwaardigerwijze wordt dit door Van Goens medegedeelde verhaal ten dele bevestigd door de Babad Sengkala. In het Javaanse jaar 1574 (begin: 15 dec. 1651) zou op de paseban een kanon uit elkaar gesprongen zijn; kort daarop werd de poort verplaatst. Dit slaat dus op het barsten van het Javaanse stuk en het toemetselen der poorten tot het grote plein (v. Goens 123).

Inderdaad verbeterde sedertdien de verstandhouding tussen Bantam en Mataram opmerkelijk, zonder dat evenwel iets over een grootscheepse 
tocht tegen Balambangan vernomen werd. Daarentegen moest de Compagnie het eerst de minder prettige gevolgen dier betere verstandhouding ervaren. De Bantammers begonnen n.l. heel onaangenaam tegen haar op te treden, hetgeen men eerst nog aan de ophitserij der Engelsen, met wie de Republiek toen juist in oorlog was, meende te moeten toeschrijven. Toen echter het tienjarige bestand met Bantam afliep, viel het op, dat Batavia leed onder de boosheid der ,wedersytse nagebueren”.

Vervolgens vond de betere Matarams-Bantamse verhouding haar uitdrukking in een huwelijksplan, waarvan Batavia pas hoorde, toen het in 1656 afsprong.

\section{Breuk in de Bantams-Mataramse vriendschap. 1656.}

Op 22 oct. 1656 had de onderkoopman Evert Michielsen een onderhoud met tg. Pati, wie hij ,ccurieuselijk” vroeg, „of den Sousouhounang, gelijck men hoorde, 2000 meijskens eijschte". De Javaan antwoordde, datter maer twee begeerde voor sijn soon, waertoe der wellicht 100 souden gebracht worden om uijt te kiesen, en alsoo het Bantamse hijlick af te wesen, mits de Maijesteijt die uijt sijn eijgen ondersaten hebben wilde". Belangrijker nog dan het afspringen van dit huwelijk is de daarmede gepaard gaande verwijdering tussen de beide rijken, die onder meer uit het volgende voorval blijkt.

Omstreeks begin juli 1657 waren te Bantam vier kontings van tg. Pați aangekomen, die op bevel van de Sunan voor de Sultan dit eigenaardige geschenk aanboden: een koppel veldhoenderen en een dito tortelduiven, nevens een zakje, waarin zich „,cannuris" (kanari?) bevonden, ,sijnde Javaense fruijten, daer men olie van perst". Natuurlijk had dit geschenk een betekenis, weinig vleiend voor de Bantammer (D. 11 juli 1657 p. 208).

Het antwoord was evenzo. De Sultan zond ,een scheermes, een scheer, een wit Javaens mutsken ende (een) langh wit cleet". De beide eraan toegevoegde uitleggingen voldoen weinig. Meer ligt voor de hand hierin toespelingen te zien op des Sunans geringe orthodoxie. Vromen knippen en scheren zich het hoofdhaar en hullen zich in een lang Arabisch gewaad met een witte kuluk. Hoe het ook zij, deze symbolische gedachtenwisseling droeg een vrij venijnig karakter en wees op toenemende verkoeling, die op oorlog moest uitlopen. Over deze spanning was er vreugde in Batavia, waar men bij monde van Truijtman oordeelde, dat de Javanen als twee kwade vijanden waren, die elkander het meest vreesden. Aldus hield ,het eene mes het andere in de scheede”. 
Het tweede Bantams gezantschap. 1657.

Hoe gespannen de verhouding tussen Mataram en Bantam was, blijkt ook uit de aankomst te Djuwana op 8 aug. 1657 van een zevental ,kloecke, wel gearmeerde Bantamse bacquelaij prauwen nevens 2 gesanten van key Mongjaja met een brief en een cleen geschenk van twee gobars, een agate paternoster en enige hanen ende vogelen" (D. 3 sept. 1657 p. 252). Daarvoor verzochten ze twee lanangs voor hun Sultan, ter onderhouding der goede vriendschap. Het geschenk was vermoedelijk al even onbeschaamd als het verzoek, aangezien in de aangeboden tasbih kennelijk weer een aansporing school om rechtzinniger te worden. Geen wonder, dat ook de twee gevraagde lanangs of oorlogsprauwen geweigerd werden, immers, alle behoorden aan de Susuhunan.

De Bantamse oorlogsprauwen zagen er krijgshaftig genoeg uit „met haer bloetvlaggen van achteren ende met piecken en schilden beseth". De Nederlandse resident Michielsen protesteerde ernstig tegen de toelating dezer gewapende gezanten en meende weg te moeten blijven uit Djuwana, als de Bantammers niet heengingen. De gelijktijdige ankomst van Makassaarse gezanten zal de Nederlanders nog meer verontrust hebben.

Tg. Patii verklaarde eerst, dat het maar (vreedzame) gezanten waren. Met Bantam werd slechts vrede onderhouden ,tot wedercrijgingh van 60 man, die... waren weghgeloopen..., anders hadde met Bantam niets in 't $\operatorname{sin"}$ (p. 253). Later beweerde hij zelfs van de Bantammers vernomen te hebben, dat hun Sultan zich wilde onderwerpen (D. 4 dec. 1657 p. 334). Eerder had hij het al van zijn gezanten in Bantam gehoord.

Toen Michielsen op 1 sept. 1657 naar Batavia schreef, kon hij mededelen, dat tg. Pați zijn Bantamse gasten gelast had, binnen vier dagen te vertrekken. Zaken hadden zij nauwelijks kunnen doen. $\mathrm{Na}$ hun afreis was de resident weer bereid in Pați te verschijnen (D. 8 sept. 1657).

\section{Reden van Mataram's oorlog met Bantam.}

Waren de Bantammers intussen reeds begonnen, zich aan Mataramse handelsvaartuigen te vergrijpen (D. 30 oct. 1657 p. 290)?

Als reden voor de oorlog gaf de Sunan later op, dat hij de ,groote trotsheyt van de Bantammers niet langer conde verdragen" (D. nov. 1657 p. 308). Ook de z.g. Hollandse Javaan, Michael Zeeburch, verzekerde, dat de Vorst „over haere begane stoutheyt tegens sijne onder- 
danen op 't hoochste verstoort was" (D. 4 dec. 1657). Zij sloegen zijn volk in zijn eigen land dood! Doch op raad van tg. Pați wilde hij eerst de Nederlanders van zijn voornemen in kennis stellen, en terecht: zonder Batavia's goedkeuring was geen aanval op Bantam mogelijk.

Hij wilde n.l. dit rijk tot zijn vazal maken. Dit bleek duidelijk, toen de Samarangse gouverneur twee Bantamse vaartuigen veroverde en de opvarenden op een kleine oude konting met weinig water en rijst huiswaarts stuurde. $\mathrm{Zij}$ moesten hun Sultan zeggen, „dat soo niet tijdich quam, om aen den Sousouhounangh homagie te doen, dat (dan) sijn fort wel verseeckeren most" (D. 10 nov. 1657 p. 309). De Sultan kwam natuurlijk niet.

Een later stadium stelt ongetwijfeld de mededeling voor, dat de Sunan tijdens de aanwezigheid der vier strandheren, omstreeks begin nov. 1657, had "geproponeert, om met macht van volck naer Bantam te gaen ende deselve te vermeesteren". Dit zou ook gebeurd zijn, als tg. Pați zich niet verstout had om te zeggen, dat men hen moest „verschoonen, dewijl gelooffsverwanten waeren".

De geschillen waren maar door de "gemenen”, dus de kleine lieden ontstaan. Hij was er evenwel zeker van, wilde zich zelfs daarvoor verpanden, „dat den sultan van Bantam niet anders socht noch trachte, dan om sich met fatsoen onder den Sousouhounangh te begeven". Tot staving dezer bewering voerde hij meerdere argumenten aan. Hij had er nog aan kunnen toevoegen, dat het al laat in het jaar was en zelfs roekeloos zou wezen, zonder medewerking der Hoge Regering iets ernstigs tegen Bantam te ondernemmen.

Hierop was de grote aanval opgeschort en slechts een kleine expeditie naar Krawang gezonden (D. 4 dec. 1657 p. 334).

\section{De tocht naar Krawang. 1657-58.}

Intussen was de strijd reeds ontbrand.

Misschien door een boze gril van de Sunan was tg. Pați, die zich tegen de Bantamse oorlog verzet had, met de verantwoordelijkheid voor deze strijd belast (D. 4 dec. 1657 p. 334). Hij ging zelf niet mee, doch gaf van uit Mataram aan zijn lurah Patra te Djuwana last, om langs de kust westwaarts te varen en alle Bantammers op te drijven, „ende bij weijgeringe of oppositie te massacreren, of wel neus ende ooren af te snijden ende in Mataram op (te) senden" (D. 1 nov. 1657). Dit was dus het schoonvegen van de noordkust tot Krawang toe.

Een volgende faze vormt de opdracht aan de vier strandheren om ,ider met ses wel gemonteerde vaertuijgen ... de riviere van Craoan... 
te visiteren, om te zien, of die van Bantam daer quamen nestelen, om die daervandaen te doen vertrecken" (D. 31 juli 1657). Beleefd was vooraf aan de Hoge Regeering verlof verzocht: het mocht wat te dichtbij wezen! Dit was nog maar een verkenning; de eigenlijke strijd zou pas enige maanden later beginnen.

Daartoe zouden in de havens van Djuwana en Japara prauwen gereed gemaakt worden, in Japara 70, elk met 40-50 koppen bemand, waar over drie heren werden aangesteld (D. 25 oct. 1657 p. 291). Op 13 october 1657, ongetwijfeld nadat het eskader van Djuwana zich met dat van Japara verenigd had, vertrok de vloot uit laatstgenoemde plaats, ,om de wegen naer Bantam te suijveren" (D. 30 oct. 1657). In het geheel telde deze armade slechts een 50-tal zeilen, terwijl nog andere smaldelen van Tegal en Pați, zo mede een uit Samarang verwacht werden (D. 1 nov. 1657). Elk schip was met 40 tot 60 koppen bemand, wel voorzien van musketten en pieken. Sommige schepen bezaten ook twee prinsenstukjes en bassen. Een deel der vaartuigen diende voor transport en voerde een 1000 paarden mede, bestemd voor de landmacht. Als aanvoerders werden genoemd de kentols Abad-Sara of Ampat-Sara, ng. Marta-Nata's broeder, en Wangsa-Marta (D. 7 nov. 1657).

Gelijktijdig met de vloot zou een leger van 40.000 man, „daeronder tienduijsent met geweer" (de rest dus dragers), over land naar Krawang gemarcheerd zijn (D. 30 oct. 1657 p. 299). De vloot zou hen van paanden voorzien. De ongewapenden moesten door het gebergte een weg naar Bantam aanleggen en de leeftocht dragen. Later werd vernomen, dat het doel „Padia Djarangh besuijden Batavia” was, dus Padjadjaran bij Buitenzorg, wat er bedenkelijk uitzag (D. 10 nov. 1657 p. 308). Aanvoerders dezer landmacht waren de gebroeders Wira-Djaja en IdaBangsa (Wira-Wangsa?). De bedoeling zou wezen, de Bantammers vandaar te verdrijven en ,bij onwillichijt met gewelt te slaen ende te vangen, neus ende ooren af te snijden" (D. 4 dec. 1657 p. 334).

Dit krijgsrumoer werd ook in Batavia vernomen en wekte daar bezorgdheid. Nadat op 27 oct. 1657 de oude kapitein der Bataviase Javanen voor Krawang een vloot van 40 tot 50 Javaanse schepen had ontmoet en daarvan aan de Hoge Regering bericht gegeven, werd de volgende dag de ontvanger Wijnand Rutgers derwaarts gezonden. Reeds de 29e oct. 1657 haalde hij bij Krawang kruisend een Javaans vaartuig aan, dat hem de eerste berichten omtrent de Mataramse vloot verstrekte. De uitgezonden vaandrig Pieter Thonissen trof in de riviermond een 27 vaartuigen aan. De ontvangst was zeer beleefd, ook al weigerden de Nederlanders het verzochte kruit. De Javanen verklaarden, dat „wij 
en zij nu als broeders waren ende niet op ons, maer op die van Bantam gemunt hadden". Genoemde vaandrig werd met de boomwachter Spijck met twee wel voorziene sloepen ter observatie achter gelaten. Op 30 oct. 1657 werden de Javaanse hoofden op Compagnies vaartuig genood.

Behalve ter zee was de Hoge Regering ook te land waakzaam en zond een verkenning uit, „om aldaer op de wegh, die van Craoan door 't geberchte na Bantam loopt, te blijven leggen" (D. 7 nov. 1657).

Hun bedoelingen stelden de Javanen als hoogst onschuldig voor. Ze gingen alleen maar naar Bantam om te zien, wat de Bantammers daar uitvoerden (D. 25 oct. 1657 p. 291). Of wel zij verklaarden daar gekomen te zijn, ,eenelijck... om die van Bantam van Craoan vandaen te jagen", of om de kooplieden in des Sunans havens te beschermen (D. 27 oct. 1657). Ook het doel van de landmacht had weinig om het lijf, n.l. om te zien, of de Bantammers de Nederlanders daar geen kwaad deden (D. 10 nov. 1657 p. 308)!

Spoedig werd het duidelijk, dat de expeditie te laat in het jaar ondernomen was, om nog kans op groot succes te hebben. Daarom bluften de hoofden, dat zij het volgende jaar in de oostmoeson met honderden prauwen zouden terugkeren, om dan rechtdoor naar Bantam te varen. Intussen zouden ze door lieden uit Pați en Tegal worden afgelost. Van zulk een grootscheepse actie is nooit iets gekomen, integendeel. Tegen half nov. 1657 bleek de Mataramse oorlogsvloot te zijn verdwenen (D. 17 nov. 1657).

Ook het leger schoot traag op. Het was omstreeks 10 nov. 1657 nog niet eens de Tji Tarum over (D. 12 nov. 1657 p. 311). Ziekte en voedselgebrek zullen daar wel weet van gehad hebben (D. 16 nov. 1657).

Met zo weinig geestkracht werd de veldtocht geleid - immers, men had nog geen Bantammers ontmoet - dat de Nederlanders aan de ernst der onderneming begonnen te twijfelen. Het zou niets dan een komedie wezen, om de Nederlanders om de tuin te leiden (d. J. VI, 71). Het leek wel, of Matarammers en Bantammers ,onderling collusie met malckander (hadden) om ons op d'eene ofte de andere wyse t'onder te brengen". Zo was het evenwel niet.

Wel degelijk is er nog gevochten, en wel omstreeks de jaarwisseling (d. J. VI, 73). „De Matarammers (waren) ... boven langhs 't geberchte tot voorby Batavia geadvanceert ende aldaer... tegen een troup Bantammers, op haer uijtgesonden, in gevecht geweest, in hetwelck 3 off 400 Bantammers souden syn gebleven". Daarna waren de Matarammers weer afgetrokken, ,apparent door gebreck van victualie ende leeftocht". Maar dit was dan ook alles! 
Van een voortzetting van de strijd in 1658 , gelijk voorzegd was, is geen sprake. Integendeel! De Sunan stond de Bantammers weer vrije vaart op zijn havens toe, mits zij geen vaartuigen zijner onderdanen, die op Batavia handelden, ter zee lastig vielen (d. J. VI, 72). Overigens merkte men niet, dat „tussen haer eenige vordere vruntschap ofte alliantie is gemaeckt".

Het volgende jaar, 1659, hadden enige kleine roofpartijen ter zee plaats. Een vaartuig uit Pați werd door Bantamse prauwen aangerand. De lading en vier Maleiers werden meegenomen, de overigen losgelaten. De Hoge Regering duchtte er verwikkelingen met tg. Paṭi en de Sunan van (D. 9 mei 1659). Is dit hetzelfde geval, als waarop de Japarase resident doelt, wanneer hij schrijft, dat de Bantammer, die met een sterke vloot voor Batavia kruiste, enige Javanen had aangevallen, hun wapens afgenomen en zoveel levensmiddelen in beslag genomen, als ze nodig hadden? Bovendien hadden de zeerovers gezegd: „Soo sy haer weder quamen te ontmoeten, dat haer, alsoo wel als die van Batavia souden doodslaen, ende hare vaertuygen ende goederen prys maecken, also (zij) hare vyanden spysigden" (D. 21 mei 1659). Deze overmoedige taal wijst er niet op, dat zij uit naam van de Sultan handelden, die toen juist een vrede met de Compagnie overwoog.

Uit weerwraak hadden ,die van Candael...4 Bantamse praeuwen met haer volck genomen ende één man naer Bantam laten keeren, met belastinge aen den Sultan te seggen, dat den Gouverneur (van Kenḍal) haer in betalinge van de jonck, door die van Bantam... genomen ende... op Lampon gebracht ende verkocht, hadde aengeslagen". $\mathrm{Ze}$ zouden ermee doorgaan, tot door de Sultan „satisfactie" van de jonk gedaan werd.

Dit alles was geen oorlog; het waren slechts speldeprikken. De resident wenste veel meer, n.l. dat ,die natiën den anderen niet verstonden, maer malckanderen bestoockten".

Hij verbaasde er zich over, dat ,de Bantammers van Sammarangh ende Surabaya... jongst noch wel 25 nieuwe tinanghs (tinggangs) hadde(n) uytgevoert; ende op ander plaetsen en mochten sy selffs niet comen”. Dit docht hem vreemd, „als zynde één heer ende één regeringe" (D. 7 juli 1659). Er was geen oorlog meer, doch evenmin vrede.

\section{De vredesbesprekingen. 1659.}

Vermoedelijk heeft de Susuhunan de eerste schrede op het pad der verzoening gezet door het zenden van een royaal geschenk, niet uit eigen naam, doch uit die van zijn zoon, ten einde bij weigering geen 
affront te lijden. Bovendien bedacht hij niet slechts de Bantammer, doch tevens de Compagnie, de laatste zelfs het eerst (D. 13 juni 1659). Twee paarden waren met een schrijven aan de Hoge Regering aangeboden uit naam van de kroonprins. Zij waren met een "propere schenckagie" beantwoord, „om des vaders gunste”.

Twee maanden later bereikte een Matarams gezantschap, dat afwisselend wordt toegeschreven aan de kroonprins (D. 11 aug. 1659) of aan zijn vader (D. 12 oct. 1659 p. 211 en 17 nov. 1659 p. 229-30), Bantam in drie prauwen. Zeven paarden en een brief werden overhandigd. De laatste bevatte een klacht: enige Mataramse prauwen waren tijdens de oorlog door kj. Arja's volk genomen; de bemanning was weggevoerd en verkocht (D. 12 oct. 1659). Tevens ontving ook de Nederlandse resident een paard (D. 29 oct. 1659).

De Mataramse klacht werd met een tegenklacht beantwoond: in dezelfde tijd hadden de Demakkers verschillende prauwen van kj. Arja afgelopen (D. 29 oct. 1659). Zo stond men onwrikbaar tegenover elkaar.

Om zijn beleefdheid te tonen zond de Sultan enige ,gommen" (gongs) naar Mataram, doch zijn vertrek naar Pontang „uijt vermeyden" (D. 29 oct. 1659), terwijl de Mataramse gezanten op antwoord moesten wachten (D. 10 nov. 1659), doet minder tegemoetkomend aan.

Pas half november 1659 kregen de gezanten hun afscheid, met een pas om over Batavia naar Mataram terug te keren. Overeengekomen werd, dat $\mathrm{kj}$. Arja 500 realen en de overige betrokkenen een zelfde bedrag zouden betalen (D. 17 nov. 1659).

Nadien is van een sterke tegenstelling tussen Bantam en Mataram weinig meer te merken. Daarentegen vinden wij tot twee malen toe pogingen van de Mataramse kroonprins om nader met het buurland in contact te komen, op welke pogingen in een volgend deel zal teruggekomen worden.

\section{De verhouding tot Bali.}

Terwijl de Sunan uiteindelijk naar een goede verstandhouding met het Moslimse Bantam streefde, is het sedert de reeds besproken tocht naar Balambangan met Bali nooit meer in orde gekomen. Ofschoon geen Matarams leger meer oostwaarts trok, gaat nauwelijks een jaar voorbij, zonder dat men van grootse plannen tegen de Balische heidenen verneemt, vooral na de politieke ommekeer in 1652.

In 1653 wilde de Vorst Bali blokkeren. Tot zijn ergenis voerden 
Chinezen rijst in plaats van naar Batavia naar zijn Balische vijanden (D. 25 juli en 4 sept. 1653). Over alle zeestranden had hij zes oorlogsschepen aanbesteed, blijkbaar om de Baliërs aan te tasten. Hij zou zelfs graag twee of drie schepen van de Compagnie willen lenen; hij wilde niet zelf vragen, doch liever door anderen laten voorstellen $(D, 4$. nov. 1653). Er kwam dus niets van.

In 1656 nieuwe plannen. De Japarase gouverneur ng. Marta-Nata en anderen moesten op korte termijn, twee maanden, veel schepen uitrusten, zodat het met de „equipagie seer drock was" (D. 7 dec. 1656). Ieder moest twee grote gorabs bouwen en de Vorst had gezegd: „Ick wil veel vaartuijgen en geweer bijeen hebben en mij dan in den wille Gods stellen". Boze tongen beweerden echter, dat het niet op Bali, maar op Batavia gemunt was.

Een jaar later was het weer net zo: dienaren van de Sunan kwamen aan de kust om 12 gorabs, 24 lanangs en 100 kontings in zee te brengen, om dan samen met de Palembangers Bali te beoorlogen (D. 8 sept. 1657).

Intussen waren de Baliërs agressiever dan de Matarammers. Zij liepen aan Java's oosteinde een vaartuig van de vorst van Makassar af, dat aan diens gezanten in Japara gezonden was (D. 26 apr. 1659). Tevens deden zij een inval in Pasuruhan, verbrandden er huizen en vermoordden er mensen. Ng. Marta-Nata beval zijn twee schoonzonen de schade op te nemen (D. 11 juli 1659). Vandaar nieuwe uitrustingen, nieuwe plannen, onderhandelingen met Makassaren en Bantammers om samen Bali aan te tasten (D. 21 sept. en 24 oct. 1659). Vermoedelijk is toen Balambangan voor goed verloren gegaan, daar twee jaar later de herovering overwogen werd (d. J. VI, 94).

De chronische burgeroorlog der Baliërs scheen de Mataramse aanvalsplannen in de hand te werken, daar ,de vorsten op het gem. eylandt ... ettelycke jaeren achter den ander seer overhoop gelegen (hadden) ende in verscheyden factiën verdeelt synde, vinnige oorlogen tegen malcander gevoert" (Gen. Miss. 26 dec. 1661 d. J. VI, 94). Geen wonder, dat de Sunan wederom zijn strandheren gelastte, ieder zes vaartuigen uit te reden (D. 13 juli 1661).

Vooral het jaar 1663 was vol oorlogsgeruchten. Het begon al in dec. 1662: de ene dag werd met man en macht aan de vaartuigen gewerkt, de andere dag haalde men stenen voor forteressen. Nauwelijks was dit op gang, of het volk werd over vaartuigen verdeeld en weggezonden, sommigen naar Bali, anderen om de west, tot aan Tjerebon toe (D. 1 jan. 1663). Doch bij tijden weifelde de Sunan tussen een oorlog tegen 
Bali of een moord op zijn oom (D. 15 apr. 1663 p. 153). Eéns vond de Balische expeditie zelfs een begin van uitvoering. De tg. Mataram kreeg opdracht van Tjerebon oostwaarts te gaan om de Baliërs te verdrijven, doch anderhalf etmaal uit Mataram weg zijnde, werd hij teruggeroepen (D. 30 apr. 1663). Het was nog wel een maand te vroeg! De volgende maand hoorde men niet alleen van een oorlog met Bali, doch ook van één tegen Batavia, hetgeen natuurlijk waanzin zou zijn. $\mathrm{Na}$ enkele oplevingen in juli 1663 (D. 28 juli 1663) en voorjaar 1664: de Sunan zou ,wederom besendingh na Baly ... doen, om te sien, of sy haer onder den Mataran zouden begeven; zoo niet, zoude hy haer met gewelt daertoe dwingen" (D. 16 apr. 1664), stierf het gerucht over een mogelijke oorlog weg.

Vermoedelijk hield dit verband met het krachtiger optreden der Baliërs zelf n.l. in de persoon van Gusti Pandji Sakti van Buleleng, die juist in het jaar 1664 op de voorgrond begon te treden (H. J. de Graaf, Gusti Pandji Sakti, vorst van Buleleng. T. B. G. LXXXIII 1949). 


\section{V. \\ MATARAM'S POLITLEK IN SUMATRA.}

Mataram's verhouding tot Palembang en Djambi. 1651-56.

Gelijk reeds in „Sultan Agung” opgemerkt werd (p. 274-78), oefende Mataram over sommige delen van Sumatra enig gezag uit, n.l. over Palembang en Djambi. In 1651 heeft de Sunan uit beide gewesten gezanten ontvangen.

Van Goens verhaalt, dat het de pangéran van Djambi in hoogst eigen persoon was, die in april van dat jaar ten hove trok (v. Goens 91-4). Hij ontmoette hem op de 21e van die maand in een djatibos tussen Djati-Djadjar en Samarang en voerde een lang gesprek met de Djambinees over tal van kwesties. Ofschoon reeds vier tot vijf jaren achtereen ontboden, was de pangéran toen pas verschenen, zodat de Sunan terecht vertoornd was. In tegenstelling tot de Nederlanders werd hij met weinig onderscheid behandeld.

Behalve een Djambinees, reisde er ook een Palembangs gezantschap naar boven (H. R. dd. 13 juli 1651). Zij werden er beiden bijzonder lang vastgehouden, „onder vrundtlyck ende eerlyck onthael”. „Onses gevoelens", zo meenden de Bataviase heren, „zal den Jambinees ende Palimbanger niet licht weder naer hun plaetse keeren, maer op 't een of ander pretext by den Sousounangh, gelyck aen meer andere pleecht, aldaer opgehouden werden, om hare plaetsen hem te meer subject te maecken" (T. B. G. LIX, 446). Stellig werd daarbij aan Tjerebon gedacht. Dit vermoeden werd niet bewaarheid; beiden zijn heelhuids in hun vaderland teruggekeerd, hoewel niet onmiddellijk.

Het belang dezer bezoeken blijkt uit hun vermelding in de jaartalbabads. De Babad Momana meldt onder het Javaanse jaar 1573 (begin 25 dec. 1650), dat de adipati van Djambi zijn opwachting maakt; hij schenkt de kledij van een hofdienaar (Adipati Djambi sowan, njaosi panganggéné abdidalem). De Babad Sengkala vult dit aan door de komst der Palembangers te vermelden; dezen kwamen n.l. de dood huns konings berichten (Wong Djambi myang Palémbang prapta matur ratunja pedjah). 
Beide mededelingen leveren moeillijkheden op. Het vereren van een hofkledij aan de Susuhunan van Mataram klinkt bijna aanmatigend; het omgekeerde ware redelijker. Voorts is uit die tijd geen sterfgeval van een Ratu bekend, zo min bij Palembang als bij Djambi.

Wanneer de pangéran van Djambi naar zijn land is teruggekeerd, is onbekend, doch op $21 \mathrm{dec} .1652$ wordt hij er weer aangetroffen. Uiterlijk kan hij dus tijdens de oostmoeson van 1651 teruggereisd zijn. ${ }^{1}$

Waarschijnlijk heeft de Palembangse gezant langer in Mataram vertoefd. Op 6 mei wordt in het Bataviase Dagregister verzekerd, dat hij nòg ten hove is. Enige maanden later zou hij, begeleid door een groot aantal vaartuigen, de terugreis aanvaarden (D. 8 sept. 1653).

Beide gezantschappen zijn ten slotte op Sumatra teruggekomen, doch de Palembanger later dan de Djambinees. Weerspiegelt zich in dit langer verblijf van eerstgenoemde zijn sterkere verbondenheid met de Matarammer?

Eind 1656 horen we opnieuw van Palembangse en Djambische gezanten aan de Sunan (D. 7 dec. 1656 p. 33-34). Hun bedrijf draagt een sterk commercieel karakter. $\mathrm{Zij}$ moesten wachten, tot de toen gesloten havens weer open gingen, eer ze lading konden krijgen. Bij hun vertrek waren hun vaartuigen met allerlei kleingoed geladen. Het gerucht liep, dat de Sunan voornemens was een gezant naar Djambi te sturen, waartoe ieder strandheer een gorab met 50 last rijst tot geschenk gereed diende te houden. Was dit een vertoning van macht en royaliteit? 2 Of waren deze 50 last de vergelding van een geschenk?

\section{De moord op Ockersz. voor Palembang. 1658.}

Mataram's verhouding tot Palembang werd mede bepaald door de moeilijkheden, gerezen tussen laatstgenoemd rijk en de Compagnie.

Waarschijnlijk sedert 1655 was daar de koopman Anthonij Boeij voor de handel aangewezen (D. 30 juni 1657). Daar de Compagnie nog geen loge aan de Musi had, behielp men zich met een schip. Boeij had toen, naar hij zeide, een Chinese jonk aangehouden en de peper-

1 Zijn bezoek aan Japara heeft de pangéran van Djambi nog benut om relaties aan te knopen met de Portugese kapitein Manuel Croes, wic hij een vrijgeleide voor Djambi deed toekomen (D. $11 \mathrm{mrt}$. 1653). Inderdaad is dezc kapitein met zijn schip in Djambi opgedoken, waar de Hoge Regering nog vergeefs jacht op hem heeft laten maken.

2 Mogelijk waren het deze Djambiërs, die vóór 17 juli 1655 met vertegenwoordigers van de vorst van Djohor en der pangérans van Madura on Patani de Sunan 9 stukken geschut aangeboden hadden (H. R. aan Voisch dd. 20 aug. 1655 K. A. 782 p. 548 ). 
lading weggevoerd, hetgeen hem bij zijn terugkomst twee jaar later zeer euvel geduid werd. Op deze episode slaat vermoedelijk een zinsnede uit de brief van de Palembangse vorst, die onder dato 9 jan. 1659 in het Bataviaas Dagregister staat afgedrukt. In dit schrijven uitte de vorst zijn wrevel, over de koopman Cornelis Ockersz. en sprak de verwachting uit, dat het wel weer nèt zo zou gaan als ,ten tyde van den capiteyn Boey, doen hy versochte om de Quinammers, die hem vergunt waren van den pangoran; als wanneer hy, Boey, het vaertuych naer 't eylant Combara gebracht ende aldaer verbrant heeft".

Desniettegenstaande werd Boey in 1657 opnieuw voor de peperhandel op Palembang bestemd, waarheen hij op $19 \mathrm{mrt}$. 1657 met een jacht en een fluit vertrok (D.). Op 30 juni (D.) kwam hij reeds te Batavia terug met de mededeling, dat de bewoners „wegens sijn persoon niet te welgenoecht" schenen, ,sulcx sijn persoon altijts door goede wachten moste verseeckeren, alsoo (zij) het daerop sochten te leggen, om bij dees of gene occasie hem ... van candt te helpen". Boey had het echter tijdig ontdekt en was "noch ditmael haer handen ontcomen”. Deze onvriendelijke houding schreef hij toe aan de inbeslagneming van de Chinese jonk.

Aangezien het volgende jaar Anth. Boey ziek was, werd in zijn plaats de koopman Cornelis Ockersz gezonden, welke in die streken reeds lang geen goede reputatie genoot.

Op 19 dec. 1656 besloot n.l. de Hoge Regering de koopman Jacob Nolpé, die in Djambi lag, op zijn herhaald verzoek te vervangen door de onderkoopman Cornelis Ockersz (D.). Reeds op 11 juni van het volgende jaar ontving men in Batavia een brief van genoemde onderkoopman, gedateerd 22 april 1657, waarin hij meldde, dat „het scheen, of den pangoran ende grooten sijn persoon niet aangenaem was, niet connende bedenken, waervan 't selve voortquam".

Maar de volgende dag werd een schrijven van de Djambische pangeran aan land gebracht (D. 15 juni 1657 p. 182-84). Daarin verklaarde deze ,geen gevallen (te) ... hebben in den langen coopman, dat hij capiteijn in Jambij soude werden", immers, hij was niet als kapitein Jacob Nolpe, ,in sijn beleijt ende ... raedtslagen”. De lange koopman was nog maar kort in Djambi, of ,door sijne manieren van doen" waren ," alle de grooten gestoort". Daarom zag de pangéran liever de assistent Jan Wissingh, die als schrijver optrad, Nolpe opvolgen.

De Hoge Regering luisterde naar deze klacht en stelde Ockersz niet in Djambi aan, mede omdat hij zich aan particuliere handel in stofgoud had schuldig gemaakt (D. 10 juli 1657). Zij verving Nolpe, wiens 
verstand ook niet meer goed fuctioneerde, zodat het gehele comptoir in wanorde raakte, door de befaamde Pieter de Goijer, juist terug van een gezantschap naar de Chinese keizer.

Er moet daarom wel een bijzondere reden geweest zijn, waarom de Hogo Regering deze te kwader naam en faam bekend staande Cornelis Ockersz tòch naar Sumatra stuurde: personeelsgebrek, connecties?

Twee reizen maakte hij naar Palembang. Tijdens de eerste, die hij op 22 febr. 1658 aanvaardde, had hij reeds enige moeilijkheden met de utivoering van het contract. Nadat hij op 9 juni 1658 te Batavia was teruggekeerd, vertrok hij 18 dagen later opnieuw naar Sumatra. Op 25 juli d.a.v. werd hem nog de „Jacatra” nagezonden. Ditmaal vond er een ernstige botsing plaats.

Hij zou een of meer schepen hebben aangehouden, niet ver stroomafwaarts van de stad, doch nog vóór de vorstelijke Kraton. Eén was van de Mataramse kroonprins afkomstig, maar volgens een ander bericht (D. 13 nov. 1659) zou het een Japarase jonk geweest zijn. Het een sluit het ander niet uit.

Daarbij waren schoten gevallen. Kogels waren in de stad Palembang en in het hof terecht gekomen. Eén Javaan was zwaar gewond, twee inwoners licht.

De Nederlanders hadden toen een jonk uit Kambodja, die voor de Kraton gemeerd lag, op sleeptouw willen nemen, maar de Palembangers hadden het touw gekapt. Ockersz. had dit door schieten op stad en jonk willen verhinderen (P. v. Dam, Beschrijvinge 2e boek I, p. 30204).

Naderhand was deze twist bijgelegd en had men zich verzoend. Ockersz. was door de Vorst zelfs tot tumenggung of opperrechter verheven, begiftigd met een kris en een piek, en onder gongslag (gamelanmuziek?) tot ,soon van den Pangoran" uitgeroepen.

Maar kort daarna, op 22 aug. 1658 (K.A. 1115 p. 28 in Afg. Patr. Miss.), had de verraderlijke overval plaats gevonden. Onder schijn van vriendschap waren de Palembangers aan boord gekomen en werden zelfs tot in de kajuit ontvangen. Niemand had argwaan gekoesterd. Als maar drie man hun wapens bij de hand hadden gehad, zou er niets gebeurd zijn, meende de Hoge Regering achteraf.

Thans volgde een algemene slachting: 42 man werden gedood; 24 wisten met de sloep naar Djambi te ontsnappen; in gevangenschap bleven er 28, van wie er spoedig drie overleden. Corn. Ockersz. behoorde tot de eersten, die vielen.

Blijkens schrijven van de pangéran Ratu, dat op 9 jan. 1659 door 
een Chinees te Batavia bezorgd werd, was deze vorst zeer verbitterd over de koopman Ockersz., die ook hij „,capiteyn Panjangh”, dus de lange kapitein, noemt. In willekeur zou hij zijn voorganger Boey hebben overtroffen. Hij zou „daetelyck de roode vlagh (hebben laten) waeyen ende seyde: wat is aen den pangoran van Palembangh gelegen?".

De tuchtiging van Palembang. 1658-59.

Nadat de Hoge Regering over Djambi van het drama op de Musi bericht ontvangen had, zond zij er de koopman Truijtman op af met enige vaartuigen.

Deze had een dubbele opdracht: 1e de Palembangers onder druk te zetten door hun scheepvaart te belemmeren; 2e met de pg. Ratu onderhandelingen aan te knopen, ten einde ten minste vergoeding der geleden schade te erlangen, de vrijlating der gevangenen te bewerken en de oude relaties te herstellen.

Daartoe werden aan pg. Ratu brieven gericht, waarop deze tot twee maal toe antwoordde. Het laatste schrijven was een correctie van het eerste (D. 9 jan. 1659) en werd tussen 15 en 29 dec. 1658 door Truijtman ontvangen, te gelijk met een brief van de gevangen stuurman Jacob de Graeff en de chirurgijn mr. Isaach.

Ofschoon de pg. Ratu op het wangedrag van Ockersz de nadruk legt, blijkt hij toch niet afkerig van een goede verstandhouding, omdat de „Sr. Capiteijn tot Batavia (de G.G.) niet het minste quaet heeft bedreven, maer ... den Capiteijn Pandjangh alleen; daerom heeft den Pangoran denselven laten dooden".

Niettegenstaande dit zachtmoedige schrijven ging de oorlog onverzwakt voort. In jan. 1659 bemanden de Palembangers de veroverde Nederlandse bodems en voorzagen ze met lange riemen. Bijgestaan door honderden kleine vaartuigen meenden zij daarmede de twee jachten der blokkadevloot af te lopen. $\mathrm{Zij}$ werden echter zodanig met grof geschut en musketten begroet, dat hun de lust tot herhalen verging (D. 8 febr. 1659).

Dit verhinderde de Pangéran niet, ten einde „de onse in de besettinge te diverteren", een gevangene, de genoemde mr. Isaach, uit te leveren. De overigen werden des te strenger bewaakt.

Daar men zo niet opschoot, besloot de Hoge Regering op 7 oct. 1659 een aanzienlijker macht naar de Musi te sturen: behalve het schip „Orangie" 8 galjoten en 2 sloepen onder de kommandeur-majoor 
J. van der Laen, bemand met 700 ervaren soldaten. Truytman werd secunde (D. 10 oct. 1659). De 19e october lichtte de vloot het anker, nadat de vorige dag de predikanten aangezegd was enige weken achtereen in de publieke gebeden den Here te smeken de krijgsmacht met victorie te zegenen, „tot een schrick van andere omgelegen Moorse princen" (D. 18 \& 19 oct. 1659).

Op 4 nov. 1659 was de vloot na 17 dagen ,stribbelings" voor Palembang gekomen; vier dagen later begon de aanval. Achtereenvolgens werden de 1e, $2 \mathrm{e}$ en $3 \mathrm{e}$ sterkte in storm genomen, zodat men op 23 november de ,goede successen ende victorien" naar Batavia kon melden. Vorst en volk waren het bos in gejaagd, stad en hof de prooi der vlammen geworden. De buit bestond o.a. uit 73 grote en 150 bronzen stukken. In Batavia vond groot vreugdebetoon plaats: luiden der klokken, lossen van het geschut, branden van pektonnen, terwijl in de Grote Kerk God gedankt werd. Helaas had men bij de dalem de Nederlandse gevangenen gekrist in het blok aangetrofen (P. de Roo de la Faille, Uit den Pal. sultanstijd p. 326).

\section{Indruk van Palembang's bestraffing. 1659.}

Wat er in de jaren 1658 en '59 op de Musi-rivier gebeurde, ontging de Indonesiërs zeker niet. Voor het eerst waren twee niet onaanzienlijke schepen in handen der inheemsen gevallen: een jacht en een fluit. Een aantal Nederlanders had het leven gelaten; 25 zaten nog gevangen. Dat de wijze, waarop dit succes behaald was, niet door de beugel kon, pleegt weinig gewicht in de schaal te leggen. De eerste vergeldingsmaatregelen der Compagnie getuigen van weinig kracht: een maandenlange blokkade met weinig schepen.

Bovendien waren de Javanen er nog op bijzondere wijze bij betrokken. Gelijk wij reeds zagen, zou Ockersz zelfs een Javaans vaartuig met peper, dat aan de Mataramse kroonprins toebehoorde en een brief aan de Palembangse pangéran bracht. doorgeschoten hebben, waarbij een Javaan het been verbrijzeld was (D. 9 jan. 1659).

Ook had Truijtman's blokkadevloot verschillende Javaanse vaartuigen aangehouden. Zeven grote Javaanse schepen hadden, van Malaka komende, Palembang willen aandoen om er kleden tegen peper in te ruilen, doch zij waren ,alle in der minne affgewesen”. Dit meldende merkte Truijtman nog op, dat ,de Javasen vaert van d'Oost om peper ... aldaer veel grooter ende yveriger (scheen) te syn als wel voor dato". De Javanen zouden er op uit wezen, om ,die negotie van daer aen haer 
te trecken ende alsoo d'Engelsen ende die van Macasser daermede te gerieven".

Er zou dus alle reden voor de Sunan bestaan, om door de partij der Palembangers te kiezen, zowel de handelsbelangen zijner onderdanen als zijn rechten van heer over Palembang te verdedigen. Wij bespeuren daar echter zeer weinig van, ook al waren de Nederlanders er voor bezorgd, b.v. toen de beschonken resident Van Hoorn tg. Pați in zijn residentie opzocht en daar de order van de Sunan te horen kreeg, „om de Hollanders van Japara op te seggen” (D. 26 april 1659 p. 78). In Batavia schreef men dit strenge bevel, dat nooit werd uitgevoerd, aan Compagnie's oorlog met Palembang toe.

Daartegenover staat, dat volgens sommige berichten de Sunan in het Palembangse conflict de zijde der Compagnie scheen te kiezen. Zo had een spion de resident Michielsen verteld, dat de Sunan gevraagd had, ,.om wat redenen de Hollanders oorlooghde met die van Palimbangh". Daarop zou geantwoord zijn, dat slechts de Hollanders de daar vallende peper mochten kopen en daarom twee met peper geladen jonken hadden aangehouden en ontladen. De Sunan had toen gezegd: „De Hollanders hebben recht" (D. 21 sept. 1659 p. 195-96).

Evenzo toen er gezanten van Palembang, Djambi en Bawean ten gehore bij de Sunan verschenen. De Palembangers hadden de bedoeling te klagen over de dreigende aanval der Nederlandse vloot (D. 15 dec. 1659). Bij het gehoor was echter van ,de oorloch tusschen de Compagnie ende Palembangh gantsch geen gewach gemaeckt". Zelfs zou de Sunan gezegd hebben: „Soo haer meesters het wel meenden, waeromme (zij) in syn lant dan mede geen logie als de Hollanders hielden, ende die altyt door een der grooten te bewaren". Hij had zelfs, na het verzuim der nalatige vazallen Suka-Dana en Bandjar-Masin gelaakt te hebben, o.a. verklaard: „,dat niemant van die overzee quamen beter waren dan den capiteyn Moor op Batavia, alsoo alles, dat van noden hadt, daervan conde crygen” (D. 7 oct. 1659 p. 208). Twee ,dwarskyckers" hadden ook vastgesteld. dat zelfs na de tweede audiëntie „by den Palembanger het minste geen gewach gemaeckt was van den oorlogh" (D. 13 nov. 1659). Durfde hij niet onuitgenodigd daarover te spreken? De Sunan had hun zelfs kwalijk genomen, dat zij zonder brief hunner heren gekomen waren, waarop het antwoord luidde, dat zij „maer quamen om homagie te doen ende te horen, wat haer van de Sousounangh soude gelast werden".

Al deze voor de Compagnie gunstige uitlatingen en handelingen laten zich geredelijk verklaren uit de onmacht van de Vorst, om 
iets tegen Batavia te beginnen. Daar hij het Nederlandse optreden niet kon verhinderen, bleef hem niets anders over dan het te prijzen, wilde hij niet zijn gezicht verliezen. Doch in zijn hart moet hij er diep verbitterd over zijn geweest. Hierop wijst het overdrevene zijner loftuitingen. Hij ovendrijft, om zijn ware bedoelingen te verbergen. Wat had hij anders kunnen doen als Vorst?

De Palembangse gezanten waren ten slotte maar armelijk bedacht: een pak eenvoudige gobars van 3 tot 4 realen het stuk, en ze hadden geen brief meegekregen. Begin nov. 1659 waren zij met zeven vaarutigen van Demak vertrokken, welks gouverneur hun nog wat had meegegeven om te vertieren. De Djambiërs zouden een paar dagen later volgen. Gescheiden waren ze gekomen, gescheiden gingen ze heen. De Djambinezen kwamen nooit weer; de Palembangers bleven langer trouw.

\section{Latere Palembangse gezantschappen. 1660-68.}

De Palembangers zagen in Mataram nog steeds hun toeverlaat, ook al leek de Sunan onverschillig voor hun lot. Deerde het hem inderdaad niet? Latere berichten wijzen op een diepe gegriefdheid wegens Palembang's verwoesting en een wrok tegen de Nederlanders, die er de hand in hadden gehad. Wij zullen hierna zien, dat deze gewelddaad tegen zijn vazal de stoot gegeven heeft tot een hermetische havensluiting.

$\mathrm{Na} 1659$ heeft Palembang nog meermalen een gezantschap naar Mataram gezonden. Soms werd gepoogd, maar vergeefs, Djambi tot meedoen te bewegen.

Kort na Palembang's verwoesting was de Pangéran overleden en vervangen door zijn jongere broeder, ki mas Hindi. Deze zou in 1675 de sultanstitel aanvaarden en zes jaar later als sultan Djamaluddin bekend staan (P. de Roo de la Faille o.c. p. 326).

Volgens een Tjerebonse Javaan zou hij in 1661 een gezantschap met geschenken naar Mataram gezonden hebben, die „rechtevoort al 15 dagen op Demak geweest waren, zonder nochtans licentie te hebben... om boven te komen" (D. 17 en 23 apr. 1661). Het strikt sluiten der havens zal dit veroorzaakt hebben. Blijkbaar zijn deze gezanten nooit voor de Sunan toegelaten.

Wel gingen het volgende jaar de havens weer open, doch niet vóór 1663 hoort men opnieuw van een Palembangs gezantschap. Op 31 jan. 1663 zond de Pangéran zijn sjabandar naar Djambi, om over „'t versenden van eenige gesanten nae den Mataram met den Pangoran van Jamby te delibereeren" (D. 24 febr. 1663). In afwachting van de 
terugkeer van deze havenmeester had men op $10 \mathrm{mrt} .1663$ nog niet besloten „den Mataram hommagie” te doen (D. 20 mrt. 1663).

Doch er waren meer belemmeringen. Het bericht van de moord op de gouverneur van Japara, ng. Marta-Nata, gaf „den Pangoran al wat naedencken, om niemand van de grooten derwaerts te senden" (D. 14 mei 1663). Ten slotte werd de stoute stap gewaagd. Twee gezanten, kj. demang Among-Pradja en Derpa-Juda zouden naar Mataram gaan, „alleen om haer te ontschuldigen, dat se sonder syne kennisse den oorloge met de Compagnie aengevangen ende... weder vreede gemaeckt" hadden (D. 20 dec. 1663). De Pangéran van Djambi, die niet meedeed, zou door kj. Wira-Sasmita, welke omstreeks 1 nov. 1663 derwaarts vertrokken was, op de hoogte wonden gesteld. Tevens zou hij onlusten tussen beide rijken bijleggen. Maar het volgende jaar was nog niemand naar Mataram vertrokken en werd Djambi nog steeds over meedoen gepolst. De oude Pangéran voelde er wel voor, want hij zond een gillon met 35 man en wat kleden naar Japara, ,zoo hy seyt, om te verhandelen, maer misschien om daermede aen den Sousouhounangh Mattaram hommagie te doen".

Duidelijker is het Palembangse gezantschap. De Pangéran, zo schreef de onderkoopman M. Hurt aan de Hoge Regering, was doodsbang voor de Matarammer, zodat hij zich niet op de Compagnie dorst te verlaten. Ofschoon de resident hem hulp in het vooruitzicht stelde en de Mataramse bezending ontried, ondernam de Pangéran deze toch en zond vier man met kloeke vaartuigen naar Java. Hun nederige boodschap luidde: „dat de Sousouhounang den Pangoran gelieve te excuseren ... dat hy nu sonder Zyn Mayts. kennis vrede met de Compagnie gemaekt hadde, want hy daertoe gedwongen was... eensdeels door de jaerlykse besettingen (blokkade) van de Compe., die de negotie dede verloopen en de leeftocht verminderen,.... anderdeels door den inlandsen oorlogh tegen syn eygen bloetverwanten, die hem na de kroon tasteden. Wat aenging de beschuldiging... van dat hy de wapenen tegen de Compe.... hadde opgenomen, 't selve was by den vorigen Pangoran... geschiet". De boodschap is dus nagenoeg dezelfde als een jaar geleden (D. 28 mrt. 1664). Daarom verzocht hij, ,met Zyn Mayt. in alle onderdanige gehoorsaemheyt en vruntschap te mogen leven".

Als de Sunan deze verontschuldiging mishaagde en hij afkeurde, dat aan de Compagnie een loge beloofd was, zou, volgens sommigen, de voltooiing daarvan wellicht verhinderd worden.

Op 9 apr. 1664 kwam het gezantschap voor Samarang aan met geschenken voor Sunan en rijksbestuurder. Het doel was, te „klagen 
over het groot gewelt, dat den Pangoran van de Hollanders wiert aengedaen". Was dit de ware bedoeling, verscholen onder nederige frazes? De gezant mocht echter nog niet opwaarts reizen, alvorens de Sunan van zijn komst verwittigd was (D. 20 apr. 1664 p. 128).

Blijkbaar viel het oordeel over hun persoon ongunstig uit, althans, de tg. Mataram liet weten, dat het de Sunan niet gelegen kwam hen te woord te staan, ,dewyl hy impotent was en de grooten in de Mattaram seer veel te doen hadden" (D. 17 mei 1664). De Palembangers konden dus wel vertrekken. Zodra de Sunan „wat reconvaliseerde", zou hij hun verzoek voordragen. Daarom mochten ze over zes maanden terugkomen, want dan zouden het de aanzienlijken minder druk hebben.

Niettegenstaande deze onheuse weigering bleven de Palembangers met hun zes vaartuigen in Samarang wachten. De gezant kreeg zelfs herhaaldelijk last te vertrekken, ,alsoo de Javanen hem niet weerdig en achten, die chergie te bekleeden". Hij was maar een vrij koopman (particulier), die vóór 1661 van al zijn bezit beroofd was, omdat andermans vrouwen in zijn vaartuig waren aangetroffen. Inderdaad was dit geen presentabel persoon.

Langzaam drong het tot hem door, dat zijn zending zou mislukken. Hij zond drie zijner vaartuigen op 13 juni naar huis en bleef met de overige nòg wachten. $\mathrm{Hij}$ hoopte ten minste op nadere tijding of op een brief van de tg. Mataram (D. 22 juni 1664).

Het eindresultaat was nihil, want in aug. 1664 kwamen de afgezanten onverrichterzake thuis, ,zynde niet... erkent, noch ook toegestaen om aen lant te comen, maer gelast in hare vaertuygen te blyven; en soude d'ordre van den Mattarammer expres leggen van niemant dier Coningen gesanten tot d'opreyse ... t'admitteren, als alleen Hare Hoogheden selver" (D. 26 nov. 1664 p. 498).

Alle zelfvernedering was dus voor niets geweest. Slechts de Palembangse Pangéran wenste de Susuhunan voor zich te zien hurken, anders niemand.

Gezien dit ontmoedigend resultaat is het begrijpelijk, dat er in Palembang met een nieuw gezantschap weinig haast werd gemaakt. In 1668 heette het, dat de Palembanger in geen drie jaar ,homagie" gedaan had (D. 31 mei 1668). Daarom werden, volgens een Tjerebons bericht, „om de Oost” oorlogsvaartuigen gereed gemaakt met Sumatra als bestemming.

Dit hielp blijkbaar; althans enige maanden later lagen vier vaartuigen met gezanten van de Palembangse Pangéran voor Samarang. $\mathrm{Zij}$ 
brachten behalve een olifantje een partij „kleedingh" ter waarde van 2000 rijksdaalders. Hun bedoeling zou zijn, om hulp tegen Bantam te vragen.

De geschenken had de Vorst aanvaard, ten minste ten dele, maar hun opreis niet toegelaten, daar de gezanten niet ,hoog genoegh van qualiteyt" waren. Doch als de „tweede persoon van 't ryck met een geschenk van 20.000 rijksdaalders quam, ... soude denselven audientie werden vergunt" (D. 13 juli 1668). Als hij niet spoedig verscheen, wilde de Sunan Palembang beoorlogen, evenals die van Djambi en Borneo (dus wel: Bandjar-Masin en Suka-Dana). In elk geval was de aanwezigheid van de Pangéran zelf niet meer vereist.

Hoe weinig dit Palembangs gezantschap in de smaak van de Matarammer viel, bewijst het armelijk tegengeschenk, dat stellig een symbolische betekenis had: „4 koebeesten, 1 ploegh ende een harck”. Ook mochten ze niet vertrekken.

Aanvankelijk kreeg de Hoge Regering de indruk, dat „de Palembangers deze Vorst, die slapende was, ... wacker gemaeckt" hadden. Hij zou immers gezegd hebben: „Sy moeten voor imandt in vreese wezen, dewyl (zij) nu in sooveel jaren nooyt ten hove gecomen syn. Ick moet haer dat beter doen voelen. ( $\mathrm{Zij}$ ) zullen my voortaen jaerl. van ijder hooft... één Rd. tot hooftgelt opbrengen; soo (zij) dat niet naer en comen, zal (ik) haer met middel daertoe brengen" (d. J. VI, 174).

Deze geweldige woorden zijn hoogstens een opwelling geweest. Immers, een halve maand later zou hij zich veel minder zelfverzekerd hebben uitgedrukt. Hij zou toen van plan zijn, „om die van Palimbangh over te geven en voortaen onder Batavia te laeten sorteren, willende met haer niet te doen hebben, omdat sy meer gehoorsaemheyt aen den Gouverneur-Generael bewesen als aen hem" (D. 29 juli 1668; d. J. VI, 174--75).

Intussen moesten de Palembangse gezanten ongetroost vertrekken. Al hun geschenken konden ze weer meenemen, uitgezonderd het olifantje. Vóór 1 dec. 1668 waren ze weer thuis. Dat zij niet in gehoor waren ontvangen, schoven zij op „de droeffheyt van den Vorst over het overlyden van een syner wyven die hy lieff hadde gehad". Dit excuus stemde hen „noch al redelyck vergenoegt" (d. J. VI, 113). In deze betreurde overledene is wellicht de vermaarde ratu Malang te herkennen.

Nadien zijn geen Palembangse gezanten meer naar Java gevaren.

Daarentegen zijn wel Javaanse gezanten naar Palembang getogen, 
t.w. die van de kroonprins na zijn droevige nederlaag te Gegodog (D. 18 jan. 1677). Zijn verzoek om ,adsistentie" bleef niet onverhoord. „10 Cloecke bemande Palembangse vaertuygen" werden voor Samarang bestemd. Inderdaad vertrokken begin maart twee Palembangse hoofden met wat volk naar Java om de pg. Adipati Anom te helpen. Als geschenk brachten zij kleden en was (D $23 \mathrm{mrt} .1677$ ). In een brief van 16 april 1677 werd hun aankomst op Java door admiraal Cornelis Speelman bericht, maar niet toegejuicht. Integendeel, hij besloot hen „sonder verlet na huys te doen keeren en aen de pangeran Depaty en Wangsa Diepa - de gouverneur van Japara - over het aennemen derselver te doleeren". „Sonder krenking van Compagnies respect” kon men daar niemand in toelaten. Speelman zag de Palembangers'dus louter als vreemde indringers. Zelfs toen was dus aan de Nederlanders de ware verhouding tussen Mataram en Palembang niet recht duidelijk. $\mathrm{Zij}$ onderschatten de banden, die het rijk aan de Musi met dat der Javanen verbonden.

\section{Djambi's breuk met Mataram. 1663.}

Tijdens het geschil tussen Palembang en de Compagnie had Djambi geenszins de zijde van zijn buurman gekozen. Terwijl de Musi geblokkeerd werd, bleef in Djambi de ,toestandt, soo in negotie als hooffsche saecken, noch al op den ouden voet... dravende". Gaarne had de Pangéran gezien, dat Batavia zich niet tot een eindeloze blokkade beperkt had, maar enige macht te land had uitgezonden (D. 7 febr. 1659). Kort daarop zouden de Djambiërs zelfs bemiddelen tot een verzoening tussen Bantam en het Kasteel.

Dat Djambische gezanten dat jaar juist samen met die uit Palembang voor de Sunan verschenen, moet meer aan toeval dan aan opzet geweten worden. $Z_{i j}$ hadden de reis niet gezamenlijk gemaakt; afzonderlijk zijn zij ook weer vertrokken, de Djambiërs om nooit weer terug te keren.

Meermalen hebben de Palembangers gepoogd, Djambi tot een nieuw gezantschap over te halen. De oudere generatie stond niet afwijzend tegenover het onderhouden van goede betrekkingen met Mataram, doch de jongeren voelden daar weinig meer voor.

Begin jan. 1663 bevonden zich Mataramse gezanten in Djambi, t.w. één uit Djuwana (Pați) en de ander uit Japara, voorzien van beleefde

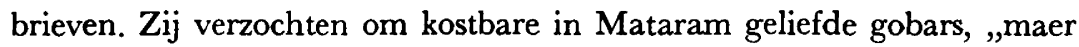
de resident (van Djambi) meent, datter wat anders onder schuylt" 
(D. 6 febr. 1663). Moesten zij een gezantschap uitlokken? Kort daarop kwam er ook een Palembangs gezant, „om haer te beraden op 't stuck van de hommagie aen den Mattaram te doen". Deze gezant was de sjabandar van Palembang en de onderkoopman Jan Claesz aldaar had vergeefs gepoogd de Pangéran dit gezantschap uit het hoofd te praten (D. 24 febr. 1663). De Hoge Regering duchtte, dat de Djambiërs ,mochten resolveeren haere submissie aen den Sousouhounang te vernieuwen" en zou hen daarvan trachten te "diverteeren” (D. 28 febr. 1663). Anders mocht die vorst (van Mataram) ,noch moediger... worden, als hy rechtevoort" was.

Deze bezorgdheid was overbodig. Vele groten, en vooral de jonge Vorst waren sterk tegen toenadering tot Mataram gekant. Hij wilde n.l. als ,koning regeeren en niet als vassael, of anders ... het ryck resigneeren”. Eens barstte de jonge prins uit: „Onse voorouders syn souveraine Koningen geweest; waerom en souden wy het niet syn? Soo myn vader sich op de capitain Moor betrouwde, soo en behoefde hy voor den Mattaram niet te vreesen" (D. 5 apr. 1663). De oude Pangéran was. echter niet te bewegen, ,sich t' eenemael van 't Mataramse hof (te) separeeren".

Evenwijdig met deze kwestie van het gezantschap naar Mataram, liep die van het huwelijk van de jonge vorst. Hij had de keuze tussen een Palembangse en een Bantamse prinses. Echter, wanneer het huwelijk met de eerste door zou gaan, diende de bruidegom zich in Palembang te vestigen (D. 6 febr. 1663 p. 30). Omdat deze daartoe ongenegen was, ,is dit aengevangen contract van houwelyck soo goed als gebroken”, hetgeen de Compagnie, evenals de meeste Djambiërs, aangenaam was.

Daarentegen voelde de pg. Dipati veel meer voor een huwelijk met de zuster van de Bantamse sultan, ,maer den ouden Pangoran en sou dat niet geerne sien, uyt vreese voor den Mataram" (D. 5 apr. 1663).

Behalve dat de jonge Pangéran sterk ,inclineerde,... om sich met den Sultan van Bantam te vermaegschappen", streefde hij ook naar een ,ligue offensyf tegen den Mataram mèt de Compagnie" (D. 9 apr. 1663). Ook de omliggende vorsten van Djohor en Indragiri wilden van de partij zijn, „daer den ouden Pangoran uyt vreese voor den Mataram tegen aen siet". In Batavia achtte men zulk een verbond ,noch slimmer” dan het Palembangse huwelijk (D. 20 mrt. 1663).

Op 17 mei 1663 kwam uit Djambi ongeroepen het Compagnies opperhoofd Evert Michielsen te Batavia, „op het versoeck ende in qualiteyt als gesant van den pangoran Ratoe van Jamby" en wel met een belangrijk bericht. Onder meer diende hij de Hoge Regering voor te dragen 
„de separatie van syn Hoogheyt van 't Mataramse hof' (D.). Bovendien verschenen nog twee Djambische gezanten, kj. dem. Nayaria de Wangsa, zoon van tg. Surja-Nata, eerste raadspersoon en opperrechter, en een zekere kj. Ngabéhi. Dezen kwamen plechtig de "successie in 't ryck" van de jonge koning melden, doch ook om „te betoonen syne genegenheyd om sich van den Mataram af te snyden en met de Compe. nader te verbinden".

De jonge Vorst had dus het roer van het bewind aangevat, doch tevens omgewend. Hij was vast besloten aan Mataram geen onderdanigheid meer te betonen en een Compagniesgezinde politiek te voeren. Het Bantamse huwelijk zou doorgaan, ook al waren ,den ouden Pangoran ende de oude ryksraaden... er tegen, vresende, dat den Mattaram sulken affront niet ongewroken en soude laaten".

De jongeren ontkenden nadrukkelijk, ooit van zins te zijn geweest „hommagie" aan de Matarammer te doen (D. 9 juli 1664). Ook zouden zij hem nimmer om hulp hebben verzocht, zo lang hun die der Compagnie niet ontbrak.

Daarentegen was ,den ouden Coninck bedecktelyck hommagie aen den vorst van Mataram ... doende, niet eens tot exempel nemende, dat die van Palembang haer hooft seer leelyk gestooten" hadden. Bedoeld wordt het reeds besproken Palembangse gezantschap, dat afgewezen werd. Maar, merkte de resident op, „den jongen Coning heeft sulcx gansch niet in 't sin, hebbende... nog onlangs hetselve aen zyn vader verweten" (D. 1 dec. 1664).

Djambi's breuk met Mataram was dus wel definitief. Hieraan veranderde niets, dat het Bantamse huwelijk ten slotte toch achterwege bleef, waartoe de Compagnie het hare had bijgedragen (D. 9 juli en 1 dec. 1664). De Djambische vorst keek daarom sedert uit naar een Makassaarse bruid. 
VI.

\title{
MATARAM'S VERHOUDING TOT BORNEO EN CELEBES.
}

\author{
Borneo verloren. 1661.
}

Behalve Balambangan maakte ook Suka-Dana zich in de eerste helft van des Sunans regering los van het rijk.

Volgens de Babad Sengkala A. J. 1575 (begin: 2 dec. 1652) brachten toen de lieden van Suka-Dana hulde aan Mataram (Wong Sokadana séba mring Mataram). Het volgende jaar (begin 22 nov. 1653) deden dit de Siamezen. De Babad Momana stelt een jaar later oorlogen met Suka-Dana en Sijem (prang Sokadana, prang Sijem). Het eerste is aannemelijk. De hulde brengende Siamezen kunnen wel handelaars, paardekopers zijn geweest.

In 1656 en '57 werd Suka-Dana nog als rijksdeel beschouwd, daar ng. Wangsa-Radja, hoofd van Samarang, met het toezicht op dit gebied belast werd (D. 7 dec. 1656 p. 31). Over Suka-Dana stond een Pangéran (D. 12 nov. 1657).

Maar enige jaren later ergerde de Vorst zich er over, dat zomin Bandjar-Masin als Suka-Dana ,homagie quamen doen”. Hiertegen stak het gedrag van de „capiteyn Moor op Batavia" helder af, van wie de Sunan alles, wat hij nodig had, kon krijgen (D. 7 oct. 1659).

Terecht maakte de Sunan zich bezorgd. Tijdens het verblijf van de koopman Evert Michielsz te Bandjar-Masin in mei 1661 verschenen daar twee gezanten, t.w. uit Suka-Dana en Djohor. „De eerste versoeckt, doch seer bedecktelyk, dat tusschen beyde rycken van Succadana en Martapoura een alliantie offensyf en defensyf mogte worden gesloten, om den Sousouhounang Mataram, aen den welken Banjer geen homagie meer en doet, te konnen wederstaen, presenterende daertoe zyn dochter... ten houwelyck" (D. 28 mei 1661).

Formeel hebben beide Borneose rijken in 1659 het huldebetoon aan de Matarammer gestaakt. Begrijpelijk is, dat Suka-Dana, het zwakste, steun zocht bij Bandjar-Masin, om zich tegen een Mataramse aanval beter te verweren. (Zie ook: A. A. Cense, De Kroniek van Bandjarmasin p. 116). 
In juli 1668 liep in Japara nog het gerucht, dat de Sunan „die van Borneo wilde beoorlogen", waartoe alle grote havens smaldelen moesten vaardig maken (D. 1 aug. 1668). Zowel Djambi als Borneo wilde hij beoorlogen, ,soo se niet metten eersten homagie quaemen doen" (D. 13 juli 1668). Het besef, dat beide rijken Mataramse vazallen behoorden te zijn, leefde toen nog. Maar tevens blijkt uit dit bericht, dat zij reeds lang de gehoorzaamheid hadden opgezegd. 's Vorsten mobilisatie zijner zeehavens was een ijdel gebaar.

\section{Mataram en Makassar.}

Toen de Nederlandse gezant Rijklof van Goens op 7 sept. 1654 in audiëntie door de Sunan ontvangen werd, deelde deze hem o.m. mede, dat volk en vaartuigen der Makassaren, ,nu soodanich als voorheen niet in zyn land quaemen" (v. Goens 138). Bedoelde hij, dat de Makassaren hem niet meer zo huldigden, als eertijds zijn vader? Waarschijnlijk wel, daar wij na 1644 geen naar Mataram opreizend Makassaars gezantschap meer ontmoeten (Bouwstoffen III, 191). Mogelijk dat des Sunans vredessluiting met de Nederlanders in 1646 het Mataramse hof voor de Makassaren, felle tegenstanders der Compagnie, minder aantrekkelijk had gemaakt. Omgekeerd is het begrijpelijk, dat de Vorst over hun verzuim verstoord was.

Toch is Van Goens er niet in geslaagd tijdens deze ambassade de Sunan tot een oorlog tegen Makassar te bewegen, waartoe hij van zijn superieuren opdracht had. Aanvankelijk scheen de Sunan op zijn nalatige vazallen zeer vertoornd, waarop Van Goens verzekerde, dat de Makassaar door een enkele oorlogsverklaring van Zijne Majesteit spoedig zijn „contributaris” zou wezen. Zelfs het gerucht ener Mataramse mobilisatie zou volstaan om de Makassaren de Molukken te doen ontruimen. Bij goed succes zou aldus de Matarammer een der grootste koningen ter wereld zijn (v. Goens 139).

Niettegenstaande deze aanlokkelijke voorspiegelingen is de Sunan niet op Van Goens' verleidelijk voorstel ingegaan. De weerstand zijner omgeving, die de Compagnie weinig goed gezind was, bleek te sterk. Elders zal deze mislukte onderhandeling uitvoeriger beschreven worden.

Op zijn terugreis poogde Van Goens nog door een overval op twee Makassaarse vaartuigen ter rede van Japara de Javanen zo te compromitteren, dat van een Matarams-Makassaarse samenwerking moeilijk meer sprake kon zijn. Geslaagd is hij daarin niet. Er heeft zich zelfs op den duur tussen beide Indonesische rijken een zekere wederzijdse toe- 
nadering ontwikkeld, waarvan wij het verloop thans zullen trachten te schetsen.

Omtrent deze onderhandelingen tussen Mataram en Makassar zijn wij gebrekkig ingelicht. Waarschijnlijk zal men de partijen de volgende motieven dienen toe te schrijven.

De Makassaren behoefden steun in hun strijd tegen de Compagnie in de Specerij-eilanden. Dat zij hiertoe bij de machtigste Vorst in de Archipel aanklopten is verklaarbaar. Diens voorganger had tot twee maal toe voor Batavia's muren met de Nederlanders gestreden. Mocht zijn zeemacht gering zijn, te land kon hij de Compagnie sterk hinderen, in ieder geval haar troepen binden. Bovendien verbond een gemeenschappelijk geloof beide Indonesische rijken.

Anderzijds stelde ook Mataram de Makassaarse toenadering op prijs, doch verwachtte, dat de vorst van Gowa de Susuhunan als heer zou erkennen, zoals eertijds die van Palembang, Djambi, Suka-Dana en Bandjar-Masin gedaan hadden. Dat betekende dus het brengen van schatting en nederig huldebetoon. Uiteraard waren de zelfbewuste Makassaren hier moeilijk toe te bewegen.

Daarnaast is een begin gemaakt met economische samenwerking. De Makassaren, goede kooplui, vermetele zeevaarders en felle bestrijders der Compagnie, wisten de Oosterse specerijen onder haar ogen weg te voeren en aan andere Westerlingen te slijten. Bovendien waren zij destijds het enige volk in de Archipel, dat systematisch gepoogd heeft iets van de Europeanen te leren, ongeveer op de wijze, waarop Peter de Grote zich in de krijgskunst en zeevaartkunde trachtte te bekwamen. Het moest voor de Javanen aantrekkelijk zijn, zich met zulke ondernemende handelaars te associëren.

Voor zover de schaarse bronnen het toelaten, valt op, dat de toenadering steeds vanuit Makassar begon, hetgeen redelijk is. De Makassaren, bewegelijker en wereldwijzer dan de binnenlandse Matarammers, zullen eerder het initiatief genomen hebben. Als onderhandelaars zonden ze gemeenlijk geen echte Makassaren, doch Maleiers, meestal ,geestelijken", die het best op het in Mataram wat sluimerende panislamisme een beroep konden doen. Speelman noemt hen in zijn „Notitie" ook Moren en vermeldt ze in zijn lijst: kodja Ibrahim en entjik Mahmud.

\section{Het eerste Makassaarse gezantschap. 1656-57.}

In 1656 had de gouverneur van Japara een „Moor van Macassar” naar de vorst van die plaats gezonden met een brief, een geschenk, en „veel offre van dienst" (D. 20 juli 1657 p. 216). 
Men mag zich ernstig afvragen, of deze Makassaarse Moor niet eerst door zijn meester naar Japara gezonden was, n.l. toen Makassar nog met Batavia op voet van oorlog stond. Deze krijgstoestand eindigde pas op 2 febr. 1656, zodat de gezant in de loop van 1655 te Japara kan zijn aangekomen, juist toen het conflict tussen Mataram en de Compagnie zijn hoogtepunt vond in de havensluiting.

Ofschoon nadien de goede verhouding tussen Mataram en Batavia hersteld werd, werden de relaties der Javanen met Makassar toch aangehouden. Met de Engelse "Jonathan" bracht een Makassaars gezant begin juli 1657 de volgende geschenken aan: twee kleine bronzen stukjes, een paard, lange zijden patolen en een partij muskus. Dit laatste kwam van de in Makassar woonachtige, rijke Portugees Francisco Viera, evenals de patolen; paard en geschut waren door de koning aan ng. Marta-Nata geschonken, ter beloning van 't geen deze gouverneur het jaar tevoren met de Moor naar Makassar had gezonden. Het vervoer per Engels schip zal voor de veiligheid geweest zijn (Vgl. de klachtbrief van de Gowase vorst: D. 26 oct. 1657 p. 294-95).

Dit gezantschap zat een maand later nog in Japara. $\mathrm{Zij}$ verzochten ernstig om een vaartuig, wilden de vriendschap onderhouden, en „hielden ernstich aen, om naer den Sousouhounangh op te mogen reijsen, om Sijn Maijesteijt te begroeten" (D. 3 sept. 1657). Dit verzoek werd hun geheel ,ontseijt”, hetgeen de Nederlanders verblijdde. Zij meenden, dat ,sulcke gesantschappen weijnich goets voor de Compagnie (plachten te) brouwen".

De afwijzing ging van het hof uit, dat de Makassaren onwaardig achtte, om voor de Sunan te verschijnen. Dit belette de gouverneur niet, hen te begunstigen. Eind aug. 1657 was hij druk met het zeilree maken van een jacht voor de Makassaar, hetgeen hem belette het aan de Compagnie toegezegde hout te leveren (zie ook: D. 8 sept. 1657).

Mogelijk is deze Makassaarse gezant dezelfde als ,intche Mahomet”, met wie de Javanen begin november 1657 de gek staken (D. 17 nov. 1657 p. 314). Hij blijkt een uitstapje naar Djuwana te hebben gemaakt en, teruggekeerd in Japara, daar aanvankelijk goed ontvangen en gehuisvest te zijn. Zijn vaartuigen waren binnen de boom gehaald, zodat hij wel vooreerst niet zou weggaan.

In een volgend schrijven dd. 17 nov. 1657 (D. 4 dec. 1657 p. 334-35) wordt behalve deze Mahomet nog een entjik Bantam vermeld. De resident noemt beiden „Macassaerse twistmaeckers”. „Ter sluijps” waren zij naar Samarang vertrokken, ,alsoo den gouverneur van Japara haer aenzijn verveelde, vermits maer groots opgaven ende geen effect 
volgden, ende met geslooten handen bleven sitten". Waren ze niet vrijgevig genoeg? Hun geschenk aan de Sunan bestond slechts uit „slechte esmarautjes". Men vertrouwde, dat ze evenmin op Samarang duurzaam welkom zouden wezen; dus wel helemaal niet Mataram.

Hiermede eindigen de berichten over dit eerste Makassaarse gezantschap, dat op niets was uitgelopen.

Het tweede Makassaarse gezantschap. 1658-59.

Omstreeks het midden van 1658 waren opnieuw Makassaarse gezanten aangekomen. Pas na twee maanden wachten werden zij naar het hof geleid, hetgeen een hele vooruitgang was, vergeleken bij de ontvangst een jaar tevoren (d. J. VI, 73). Blijkbaar dankten de Makassaren deze gunsten aan het feit, dat de voornaamste gezant zich bij de gouverneur ng. Marta-Nata voor een oom van de Sultan van Gowa had uitgegeven. Toen hij slechts van geringe stand bleek, zou de Sunan weinig werk meer van hem gemaakt hebben (D 28 febr. 1659 p. 38). Dit is overdreven, ook al vermeldde de Sunan later bij het keren van het tij de stuitende bijzonderheid, dat zij hem in hun strijd tegen Nederlanders en Baliërs om geld hadden gevraagd. Hiervoor waren zij natuurlijk aan het verkeerde adres (D. 13 nov. 1659). Ook hadden zij de Vorst aangeboden, Bali voor hem te veroveren (D. 21 sept. 1659).

Daarentegen had de Sunan hen zover gekregen, dat zij ,haer hadden laten verleyen, dat het scheen, off (hun) ... Coninck sich hadde comen 't hooft voor dien Vorst buygen", ofschoon ,dat syn meninge niet en was" (D. 7 juli 1659 p. 138). Opnieuw dus Mataram's streven, om als alleenheerser door zijn Indonesische buren erkend te worden.

Tegen de verwachting der Hoge Regering, die wel vernomen had, dat de Makassaarse gezanten, evenals ,derselver aenhangh ende 's Comps. vyanden (Portugezen?)" tegen de Nederlanders hadden gewoeld, maar nochtans daarvan ,geen veranderinge off verwyderinge in negotie off hooffsche saken" verwachtte (D. 10 jan. 1659 p. 9), kwam er een Matarams-Makassaars verdrag tot stand.

Er werd afgesproken, dat men ,alle jaren door wedersytse gesanten den anderen (zou doen) ... begroeten” (D. 13 mei 1659 p. 97). „Onder beloften van den anderen trou te blyven", kreeg iedere gezant van de gouverneur ng. Marta-Nata nog 7 last rijst, terwijl de vaartuigen voor de terugreis, elk 20 last groot, hun door de Sunan geschonken werden. Dit geschiedde, ofschoon te voren tussen de gezanten en de Japarase gouverneur wrijving was geweest; de Javaan had het Makassaarse 
geschenk te karig vergolden, „daerover denselven gesant hem seer belghde" (D. 28 febr. 1659 p. 38).

Toen het gezantschap ultimo februari 1659 vertrok, werd het met „groote statie... uytgeleyt" (D. 26 apr. 1659). Tg. Pați had zijn Japarase ambtgenoot en mededinger de gunst benijd, de Makassaren te mogen ontvangen en noodde hen daarom naar zijn haven Djuwana. $\mathrm{Zij}$ bedankten echter voor de eer.

Rumphius (II, 128) verzekert eveneens, dat „den Soesoehoenan... met den Maccassaar in verbintenisse was gecomen van gemeene offensie en defensie, tot welken eijnde ook 20 joncken te Sourabaija voor de Maccassaren wierden opgetimmert". Dit is dus een aanvallend en verdedigend verbond, waarbij aan Makassar vaartuigen waren toegezegd, die buiten het oog der Nederlanders te Sura-Baja op stapel waren gezet. Daar ook Valentijn (IV, 104) van een dgl. verbond weet, valt er moeilijk aan te twijfelen.

Doch al spoedig vond een grote verandering plaats. Kodja Ibrahim, de gezant, had door de Oostmoeson Makassar niet meer kunnen halen en was naar Japara teruggekeerd. Evert Michielsen, de resident, verheugde zich er over, dat deze ,snoden gast... boven by de raedslagen niet present" zou wezen (D. 26 apr. 1659). Deze besprekingen zullen omstreeks half april in Mataram gevoerd zijn en moeten wel Makassar betroffen hebben, anders zou er voor Michielsen geen reden tot vreugde geweest zijn. De uitslag bleek al spoedig.

Kodja Ibrahim kreeg van de Sunan de boodschap, zijn vorst te verwittigen, dat hij het zenden van gezanten kon nalaten. $\mathrm{Ze}$ zouden n.l. toch niet meer ten hove toegelaten worden (D. 13 mei 1659, p. 97). Kodja Ibrahim had daartegen geprotesteerd, zeggende, dat dit tegen het besluit der wederzijdse bezendingen was. Hij zou het evenwel overbrengen. Inmiddels bleef hij ,by yder ongeacht sitten, alles recht contrarie de vorige eere ende beloften". De eerst zo gevierde gezant was dus in ongenade gevallen. 1

$\mathrm{Na}$ dit tweede gezantschap zijn geen Makassaarse gezanten aan het Mataramse hof verschenen. Al kwam het nimmer tot oorlog, de

1 Kodja Ibrahim treedt nog herhaaldelijk als vertegenwoordiger van de Makassaarse vorst op. In 1663 wordt hem een bedrag van 2100 realen uitbetaald, in afkorting van het 1652 van Franc. Viera genomen schip, de "Jan Baptista". Op 18 oct. 1663 (D.) komt hij over Japara te Batavia, gezonden door karaëng Sumana, om Makassaarse staatszaken aan de Hoge Regering voor te leggen. In zijn befaamde Notitie noemt Speelman hem het eerst van alle Makassaarse Moren, als Godia Ebrehim. Hij staat dan op het punt naar Bima te verhuizen. 
verhouding tussen de hoven van Gowa en Mataram was verre van goed. Zo in 1663, toen de omliggende volkeren in schrik en alarm werden gehouden door het uitrusten van de zoveelste Mataramse oorlogsvloot, schreef Batavia het ,fortificeren van de stad Macassar" aan dit dreigement toe (d. J. VI, 99). Doch meer dan dreigen werd het niet. Immers, te veel banden verenigden nog beide Moslimse rijken en Makassar's verovering door Speelman in 1669 liet de Sunan gans niet onverschillig. Hierop wordt teruggekomen (blz. 188-189).

Mataram's verhouding tot zijn vazallen pogende samen te vatten, menen wij, dat na 1660 alle rijken op één na met de vorst van Mataram gebroken hebben. Slechts Palembang bleef trouw tot het einde. Zowel Djambi als Borneo onttrokken zich aan de Javaanse suprematie. Makassar, hoewel om hulp verlegen, weigerde in een slaafse verhouding tot de Sunan te komen. Bantam, eerst nog voor zijn oostelijke buurman bevreesd, trok zich steeds minder van hem aan. Het zwakke Balambangan zelfs maakte zich van het grote rijk los.

Het is verleidelijk deze achteruitgang over bijna de hele linie in verband te zien met 's Vorsten falen tegenover de groeiende macht der Compagnie, welke juist omstreeks 1660 steeds duidelijker werd. 
VII.

\title{
DE VRIENDSCHAP MET DE COMPAGNIE.
}

\author{
De vredessluiting. 1646.
}

Het sluiten van de vrede met de Nederlanders en hun verhouding tot de Vorst gedurende zijn eerste acht regeringsjaren werden reeds besproken in: „De vijf gezantschapsreizen van Rijklof van Goens 1648-54". Aangezien hieraan weinig meer valt toe te voegen, is kortheid geoorloofd.

Vóór 30 april $1646 \mathrm{kwam}$, gelijk al meermalen geschied was, een gezantschap van tg. Wira-Guna in Batavia aan. De leden waren NajaKarti, Astra-Tala en (Angga-Djiwa).

Hun bedoeling was o.m. handeldrijven. Blijkbaar was bij hun vertrek uit Mataram, dat in het begin van 1646 moet gevallen zijn, van sultan Agung's overlijden nog niets bekend; althans in het antwoord der Hoge Regering is nog sprake van de ,sultan Mattaram". Wel schijnt zij een naderende troonswisseling te voorzien, immers, zij herhaalt nogmaals haar bereidheid tot vrede, de uitwisseling der wederzijdse gevangenen en terugbetaling der door haar in beslag genomen gelden.

Pas in een Javaanse brief, die de Hoge Regering op 19 juli 1646 beantwoordde (d. J. V, 283), moet over de troonswisseling geschreven zijn, aangezien daarin voor het eerst sprake is van de Susuhunan Mataram, terwijl tg. Wira-Guna thans genoemd wordt: „eersten raet van den Sousounangh Mattaram, groot van verstant en beminder van de vreede, die toewenschen...", enz.

In deze brief van tg. Wira-Guna, die nu ook met een veel rijker geschenk vergezeld was ( 200 gantangs rijst en 20 kapoenen) verneemt men niet enkel zijn goede gezondheid, doch ook dat hij ,den wegh tot den vrede... (zocht) te bewercken".

Evenwel, de tumenggung stelde zekere voorwaarden. Door zijn brief en de "mondelinge aenmaninge" zijner gezanten werd slechts ,goede hope... gegeven van mette Mattaram in vreede te comen", als de Hoge Regering er om verzocht en een gezantschap zond. 
Daarom werd in Rade besloten de ontvanger Sebalt Wonderaer te sturen. Tevens werden de gevangen priesters, $\mathrm{kj}$. Hadji en Suracqsacksa, losgelaten en de 57433/4 realen van achten terugbetaald, ter inwisseling der Nederlandse gevangenen door bemiddeling van tg. Wira-Guna's gecommitteerden. Ook namen de gezanten vier schone tafeldiamanten mee, die ze zelf uitgezocht en betaald hadden (Res. 14 juli 1646).

Behalve van tg. Wira-Guna waren er nu ook gezanten van de tumenggung Mataram meegekomen, hoewel zonder brief. Mogelijk moesten ze slechts tg. Wira-Guna's boodschappers beter in de gaten houden. Al deze Javanen vergezelden Sebalt Wonderaer op zijn reis naar Midden-Java.

De Nederlandse gezant zou niet verder varen dan de rede van Samarang, geen man aan land zenden en zijn vreedzame bedoeling kenbaar maken door een witte of vredevlag van de campagne te laten waaien. De Javaanse gezanten, wier twee schepen afzonderlijk voeren, zouden met de geschenken en de antwoordbrief aan wal mogen gaan en naar het hof opreizen, waarna men de verdere gebeurtenissen zou afwachten. Gevangenen zouden echter niet eenzijdig worden losgelaten, doch tegen elkander worden uitgewisseld. Op besneden Nederlanders werd geen prijs gesteld; die mochten heengaan of blijven, naar het hun goed docht, „om geen de minste obstacul in de vrede te geven en de Javaentgens de maet in alles vol te meten", als men de onbesnedenen maar kreeg (Memorie voor ... S. Wonderaer, Bat. 19 juli 1646 K.A. 773 p. 259 en vlg.).

Men kwam dus de Matarammers in zeer veel tegemoet, maar riskeerde geen Nederlands gezantschap zonder waarborg in het binnenland. Hieraan hield men hardnekkig vast. Overigens was de Hoge Regering bereid „den vrede selver te comen verzoecken”, wat in de ogen der Javanen een knieval betekende. Officieel wist n.l. de Vorst nog van niets. Daarom moest de Hoge Regering aan tg. Wira-Guna vriendelijk vragen, dat de tg. Mataram „nae syn groot vermogen by den Sousounangh Mattaram" de zaak van de vrede wilde bevorderen, zodat zij dus de eerste stap deed (Schrijven dd. 19 juli 1646 d. J. V, 283-84)!

Zelfs beloofde de Hoge Regering reeds enig eerbetoon, ofschoon verhuld, zoals het ook later in het vredesverdrag is opgenomen, t.w. dat zij bereid was voor de Sunan en tg. Wira-Guna ,soodanige cleden ende rariteyten" te bestellen, ,als van tyt tot tyt sult gelieven te ontbieden, waervan de monsters sullen verwachten". Daar laatstgenoemde toezegging feitelijk is uitgelopen op een jaarlijkse huldiging onder aanbieding van kostbare geschenken, zal reeds op deze bijeenkomst te 
Batavia over de latere vredesvoorwaarden enigermate van gedachten zijn gewisseld.

Ter rede van Samarang vond nu de uitwisseling der gevangenen plaats, terwijl het in beslag genomen geld terugbetaald werd. Ongetwijfeld zullen de besprekingen over de vredesvoorwaarden toen zijn voortgezet. Ten minste, op 24 sept. 1646 verscheen ter Hoge Vergadering een nieuw Matarams gezantschap, dat een volledig stel vredesvoorwaarden aanbood. Twee hunner droegen Arabische namen, t.w. Abdul Latif, sjabandar of havenmeester van Japara, en intche (of entjik) Kodrat; de derde heette Marta-Sara (d. J. V, 284-85). De aangeboden voorwaarden zijn stellig de vrucht van overleg ten hove omstreeks aug. 1646 geweest en dragen ook een sterk Javaans stempel. Tevens bleken deze heren, die niet meer enkel afgezanten van tg. Wira-Guna of tg. Mataram waren, doch afgevaardigden uit naam van de Susuhunan, gemachtigd hun voorstellen te wijzigen. Het resultaat der besprekingen in Batavia waren een zestal artikelen, waarvan de eerste vier gelijk waren aan die der Javanen, terwijl enkel in de laatste twee veranderingen waren aangebracht. De volledige tekst vindt men in het Corpus Diplomaticum Neerlando-Indicum dl. I, blz. 484, terwijl zij ook in de "Gezantschapsreizen van Van Goens" uitvoerig besproken werden.

Volgens artikel 1 zou de Compagnie onder het mom van een handelsreis jaarlijks een gezantschap naar de Sunan zenden, dat natuurlijk niet met lege handen kon verschijnen. Dit leek bedenkelijk veel op een jaarlijks huldebetoon.

Op grond van het $2 \mathrm{e}$ artikel zou men desgewenst voor de Sunan priesters vervoeren, b.v. naar Mekka. Dit was trouwens al eerder door de Compagnie aangeboden. Deze vergunning heeft de Sunan nooit benut.

Ten derde zouden alle in Mataram gevangen Nederlanders worden bevrijd. Uitgezonderd de besnedenen, die meest met Javaanse vrouwen gehuwd waren, hadden de Javanen reeds alle Nederlanders los gelaten. Op den duur zouden alle nog aangehoudenen hun vrijheid herkrijgen, n.l. in 1649 en 1651.

Ten vierde zouden schuldenaars wederzijds worden uitgeleverd. Dit artikel zal zijn ontstaan wel aan de Compagnie te danken hebben, die er ook het meeste profijt van zou trekken, n.l. reeds in 1648. Het betrof hier Chinese debiteuren, die zich op Matarams gebied veilig hadden gewaand.

De consequentie van het vazalschap bracht volgens de Javanen mee, 
dat men de Sunan in al zijn oorlogen hielp. De Compagnie wenste deze niet te trekken en de Vorst slechts bij te staan tegen vijanden, met wie zij niet in vrede was. Daardoor kwam er later van een onderlinge hulp bitter weinig terecht en bleef dit $5 \mathrm{e}$ artikel van geringe practische waarde.

Evenmin kon de Compagnie gedogen, gelijk gewenst werd, dat zij alle kooplieden onder 's Vorsten gezag overal vrij liet varen en handelen, evenmin de Maleiers hinderen, die naar de hofstad opreisden. Het zou de ondergang van haar handelssysteem betekend hebben. Daarom verbood het $6 \mathrm{e}$ artikel de vrije vaart op de Molukken en voorbij Malakka. Merkwaardigerwijze werd de vrije handel der Nederlanders op de Mataramse havens niet gewaarborgd, hetgeen na 1652 tot onaangename verrassingen zou leiden.

Op deze vier ongewijzigde en twee gewijzigde punten werd nu de vrede voorlopig getekend, en wel op dezelfde 24e september 1646 als waarop de Javaanse gezanten in Batavia waren aangekomen. Deze heugelijke gebeurtenis werd met kanonschoten van de Kasteelsbolwerken gevierd; de Javaanse gevangenen werden uitgeleverd.

Pas een maand later vertrokken de Mataramse gezanten in gezelschap van een eerste Nederlandse gezant naar het hof, de opperkoopman Jan Hermansz.

\section{Het gezantschap van Hermansz. 1646.}

Op 26 oct. 1646 verliet dit eerste Nederlandse gezantschap naar Mataram Batavia's rede en keerde vóór 4 febr. 1647 terug. Merkwaardig is, dat de gezant zich eerst tot de gouverneur van Japara zal moeten wenden, opdat deze hem naar Mataram zal geleiden, „daertoe... reeds volcq ende paerden gereet hout". De weg naar het binnenland loopt dus nog officieel over Japara.

De taak van de gezant was de nieuwe Sunan te begroeten, met zijn koninklijke successie geluk te wensen, en, onder aanbieding der geschenken, de ratificatie van de getroffen vrede te bewerken. Verzocht zal moeten worden, deze over het gehele land bekend te maken. Voor de Vorst zal men een tweetal paarden, de beste van stal, twee schone (Japanse?) schutsels, 34 stuks muskusballen, een kas rozewater en een vaatje Spaanse wijn bestemmen, zomede een diamanten ring, die in handen van Wira-Guna berust. Men zal zo beleefd mogelijk zijn, „met sooveel complimentos ende sausen van de hoven ... als vereyscht worden ende Ul. weten, die natie mede gedient syn". Daarentegen zal men een mogelijk verzoek, om de Sunan tegen Bantam te helpen, beleefdelijk 
van de hand wijzen, aangezien de Hoge Regering zo juist met dit lastige buurrijk een tienjarige vrede gesloten had. Het meereizende volk 20 koppen sterk - zal Hermansz onder goed gezag en discipline houden. De nog aanwezige Nederlanders, tien man, besneden en getrouwd, mag de gezant, indien zij hun vrijlating kunnen verkrijgen, pardon toezeggen en naar Batavia brengen. Op het weer residentie nemen in Japara of het aandoen van deze plaats door passerende schepen, zal blijkbaar niet al te hard worden aangedrongen en in ieder geval als voorwaarde gesteld worden, dat de Nederlanders dan vrij handel drijven en desgewenst vertrekken mogen (d. J. V, 289-90).

Helaas bleef ons van dit gezantschap geen verslag of dagregister bewaard. Wij weten echter, dat de Sunan de vrede ratificeerde en aan het terugkerende gezantschap enige weinige geschenken meegaf. De Hoge Regering was zeer voldaan, hoewel van een loslating der resterende gevangenen niets gekomen was. Integendeel! Toen Jan Hermansz., blijkbaar door het droevig lot zijner landgenoten bewogen, bij tg. WiraGuna wat al te ernstig op hun vrijlating aandrong, had deze staatsman uit nijdigheid de helft om het leven laten brengen (v. Goens 62).

Tevens mag betwijfeld worden, of de gezant de Vorst zelf wel gezien heeft. Volgens Van Goens (p. 30 en 190) was de Sunan wijs gemaakt, dat de Nederlanders tovenaars waren, die met duivels omgingen enz. $\mathrm{Zij}$ verstonden het, iemand kunstig af te beelden en dan die aftekening als tovermiddel te gebruiken, ten einde de voorgestelde allerlei leed te berokkenen. Daarom zou de Sunan zich niet in persoon aan Jan Hermansz vertoond, doch een ander in zijn plaats gesteld hebben. Toen deze de proef goed doorstaan had, durfde de Vorst zich voortaan aan de Nederlanders te vertonen en werd zelfs familiaar met hen. Dit verhaal zou Van Goens uit des Sunans eigen mond vernomen hebben.

Doch hoe het ook zij, gedurende het verdere jaar 1647 kon de verhouding van de Compagnie tot de Matarammer nauwelijks beter zijn. Er was toen geen rijst uit Siam en Arakan ontvangen, doch niettegenstaande de slechte Mataramse oogst, werd Batavia door de Sunan voor hongersnood bewaard. De Vorst, ofschoon verklarende zelf sober voorzien te zijn, schonk de Gouverneur-Generaal 100 lasten rijst, ,'t welck voor een groote saecke extimeren, ende noijt gebeurt is". De Hoge Regering trok hieruit de slotsom, dat de Vorst de vrede ernstig meende en niet licht zou verbreken. Men bleef evenwel ,voor die snoode race wel op hoede", en besloot bij de volgende bezending hun geschenk rijkelijk te vergoeden, ter onderhouding der vriendschap. Daardoor immers, zou ook Bantam in toom gehouden kunnen worden. Bijna 
naief klinkt de verzekering in de Generale Missive van 31 dec. 1647 (K.A. 1064): (Wij) weten bijna niet, hoe (wij) 't hebben, dat (wij) hier nu so vredich woonen ende alomme de landen soo veijlich mogen gebruijcken". Verklaarbaar wordt deze ontboezeming als men bedenkt, dat Batavia met zijn oostelijke buurman 18 jaar lang op voet van oorlog had gestaan.

Tevens overwege men, dat in Mataram zoveel spanningen heersten, dat des Sunans verlangen naar een rustige verhouding tot de Compagnie hierdoor begrijpelijker wordt.

Het gezantschap Wonderaer-Van Goens. 1648.

Met het volgende gezantschap maakte de Hoge Regering weinig haast. Ruim een jaar, nadat de eerste gezant in Batavia teruggekeerd was, schreven de gebroeders kj. Suta en Angga-Pradja naar Batavia een brief, waarin zij meldden, dat de Sunan tijdens hun jongste verblijf ten hove herhaaldelijk naar de gezant van de (Gouverneur-) Generaal had geinformeerd. Zij vreesden n.l. bij het uitblijven van zulk een gezant uit hun ambt gestoten te worden. De Hoge Regering verontschuldigde zich met te antwoorden, dat de vloot met zeldzaamheden uit Nederland en kleedjes uit Koromandel nog niet aangekomen was. Zelfs een tweede schrijven, op 24 apr. 1648 ontvangen, vermocht de benoeming van de gezant niet te verhaasten, daar pas op 28 mei de ontvanger-generaal Sebald Wonderaer naar het Mataramse hof werd afgevaardigd. Hem vergezelde de opperkoopman Rijklof van Goens, de opsteller van het leerrijke verslag, en de kapitein der Maleiers, entjik Ahmat, die ook bij de twee volgende gezantschappen van Van Goens van de partij zou wezen. De bijbedoeling der Hoge Regering met deze ambassade was er de Vorst op te wijzen, dat nog zovelen van zijn volk naar Perak reisden, en de uitlevering van Chinese schuldenaars te bevorderen. Het geschenk bevatte o.a. drie Perzische paarden.

De ontvangst was uitstekend. Tot drie maal toe werden de gezanten op de pagelaran ontvangen. De Sunan had zelfs een jachtpartij naar het zuiden enige dagen uitgesteld, sprak hen minzaam toe, vergunde hun te zitten naar believen en overlaadde hen met geschenken. Driemaal betrof het gesprek Bali, waarmede de Vorst sedert tg. Wira-Guna's expeditie van het vorige jaar op kwade voet stond. Daar de stukken over deze zwijgen, zal hij in 1648 niet meer tot de levenden behoord hebben. Twee maal sprak de Sunan over de geschonken paarden, die 
hem niet geheel aanstonden. Er werd overeengekomen, dat hij door bemiddeling der Compagnie dienaren naar Perzië zou zenden, waar zij zelf de paarden konden uitkiezen. Omtrent paarden kunnen Javanen zeer kieskeurig zijn, daar zij aan vereisten moeten voldoen, aan Europeanen onbekend, b.v. ten opzichte van de haarwervels. Inderdaad zijn enige dienaren van de Vorst met de gezanten meegegaan.

Voor de achtergebleven Nederlanders kon helaas weinig worden gedaan. Hun toestand wordt als erbarmelijk beschreven.

\section{Het $2 e$ gezantschap van Van Goens. 1649.}

Ook het volgende, derde gezantschap was over tijd en kwam pas, nadat tg. Mataram boden had gezonden, om naar dit lang uitblijven te informeren. Ditmaal had het uitstel een gegronde reden: men wachtte op de paarden, die in Perzië moesten worden opgekocht door de drie Javaanse gezanten, welke in gezelschap van enige Nederlanders de lange reis over Gamron naar Shiras hadden ondernomen. De omstandigheden waren juist zeer ongunstig: een oorlog woedde tussen sjah Abbas II van Perzië en de Groot-Mogol Sjah Jahan om de vesting Kandahar. Na de lange reis waren de edele dieren zeer vermagerd, zodat ze eerst in Compagnies stal weer op hun verhaal moesten komen, eer men ze aan de Sunan durfde vertonen.

Van Goens, de leider van het gezantschap, werd slechts vergezeld door de reeds genoemde entjik Ahmat. Zijn opdracht luidde: de uitlevering van enige Chinezen te verzoeken en de aandacht van de Vorst op het wenselijke van wat meer orde en rust in zijn rijk te vestigen, vooral in de zeehavens, opdat de ingezetenen van Batavia daar voor overlast, geweld en moord mochten gevrijwaard blijven.

Ofschoon het laatste deel van de opdracht aanleiding tot wrijving had kunnen geven, verliep toch alles naar wens. De ontvangst was hartelijk; àlle overgebleven Nederlanders werd met hun vrouwen en kinderen vergund het land te verlaten, uitgezonderd diegenen, welke bij de kroonprins of andere hoge personages in dienst waren getreden. Dit gebaar wekte bij een Moslim verbazing. Van de westelijke buurman was men wel anders gewend. Mogelijk sproot deze liberaliteit voort uit het behagen, dat de Sunan in de paarden schepte. Boven de gewone geschenken aan de gezant beloofde hij nog 150 last rijst aan de Gouverneur-Generaal te zenden. Zelfs bracht de Vorst opnieuw het stichten ener factorij in Japara ter sprake, waartegen men in Batavia zich niet wilde verzetten. Daar te zelfder tijd ook Bantam zeer tegemoetkomend 
was en flink wat peper te koop aanbood, was de Hoge Regering uiterst tevreden over deze gang van zaken en schreef verheugd naar patria: „In somma, wy beleven, God loff, in Batavia een florissante eeuw".

\section{Het 3e gezantschap van Van Goens. 1651.}

Ofschoon het vierde Nederlandse gezantschap, het derde van Van Goens, ook weer ver over tijd was - het vertrok pas $10 \mathrm{mrt} .1651$ uit Batavia - werd het toch zeer vriendelijk ontvangen.

Deelnemers waren behalve Van Goens en de kapitein der Maleiers Ahmat, ook de opperkoopman Dirck Schouten, bestemd om aan het hoofd van het herstelde kantoor te Japara te staan. Hierom was nu door de Vorst officieel verzocht (T.B.G. LIX p. 441), doch ook de Compagnie wenste het, daar zij in de handelsvoordelen der reeds aanwezige Engelsen hoopte te delen.

Geen gezantschap is zo wel geslaagd als dit. Men zou het een hoogtepunt in de Matarams-Nederlandse betrekkingen kunnen noemen. Het zeer rijke geschenk, dat o.m. twee bronzen stukken, evenveel Perzische paarden, een vuurwerk, vijf schilderijen, tien spiegels met lofwerk en een ebbenhouten stoel bevatte, werd zeer gewaardeerd; ook het voorstel om Dirck Schouten in Japara te plaatsen, werd met graagte ontvangen. De Sunan schonk de grond voor een loge, niet enkel te Japara, maar op al zijn zeeplaatsen. Van Goens liet hier geen gras over groeien, doch ging op de thuisreis dadelijk tot de stichting van een comptoir over. Hoe goedgezind de Vorst was, blijkt wel uit zijn aanbod, om aan de Gouverneur-Generaal een aantal schone vrouwen te zenden. Zeer verheugend was ook de loslating der laatste Nederlandse gevangenen.

Een gunst, die te denken gaf, was de rondleiding door het Mataramse arsenaal met zijn werkplaatsen voor geschut en schietgeweer. Men zal zien, dat juist na dit wel geslaagde gezantschap tussen Mataram en Batavia moeilijkheden zijn begonnen te rijzen. 
VIII.

\section{HET STELSEL DER BEIDE OPPERSTRANDHEREN.}

De stad Japara in de $2 e$ helft der 17 e eeuw.

Japara's bloei dateert uit de $16 \mathrm{e}$ eeuw, toen het als grootste haven van het rijk Demak een bijzondere rol speelde. Hierover kan men het getuigenis van Tomé Pires nalezen. Zijn handel werd slechts door die van Gresik overtroffen.

Deze bloei zette zich voort in de $17 \mathrm{e}$ eeuw. Op uitnodiging van panembahan Krapjak hadden de Nederlanders er reeds in 1613 een factorij gesticht, in 1618 de Engelsen eveneens. Na de dubbele tuchtiging door Coen in 1618 en '19 werd de stad aan de zeezijde bemuurd en door de gouverneur van lage stenen bolwerken voorzien. In 1632 werd het daarom door een Nederlandse vloot vruchteloos gebombardeerd. Het hoofd, een buitenlander, dus niet-Javaan, had zich bij de verovering van Tuban zodanig onderscheiden, dat hij de oude titel van Laksamana, admiraal van de Mataramse vloot mocht voeren.

$\mathrm{Na}$ de vredessluiting van 1646 herwon Japara zijn oude handelspositie. Toen het schip van Wouter Schouten in maart 1659 er de ankers liet vallen, trof hij een welvarende, volkrijke stad aan (Aenmercklijke Voyagie I, 37). De omwalling bevond zich nog in goede toestand, de woningen waren van steen en kalk gebouwd. Straten, wallen, pleinen, wegen en omstreken zagen er aantrekkelijk uit, versierd als zij waren met fraaie gebouwen. Het wandelen was heerlijk. De pasars krioelden weer van Javanen, Perzen, Arabieren, Gudjaraten, Chinezen, Koromandelaars, Atjehers, Maleiers, Peguanen en andere volkeren. Alles wat Azië en de overige werelddelen opbrachten, scheen men er te verhandelen. Slechts de stadsaanleg kon Schouten weinig bekoren; er waren maar weinig rechte straten, terwijl de overige wegen als een doolhof door elkaar liepen. Daardoor wist men niet steeds, of men op de openbare weg dan wel op particuliere erven liep, wat nadelige gevolgen kon hebben, gezien de jaloerse aard van Chinezen en Javanen.

Boven alles viel de grote moskee op, vermoedelijk daterende uit de tijd der ratu Japara, dus uit het $3 \mathrm{e}$ kwart der $16 \mathrm{e}$ eeuw. Schouten heeft 
haar waarschijnlijk vanuit de Nederlandse loge getekend en er een gravure door C. Decker in zijn reisboek van laten opnemen onder de titel van: Der Moren Tempel binnen de Stadt Japare. Deze vierkante moskee zonder surambi (voorhal) was omringd door water, evenals de huidige Vorstenlandse kratonmoskeeën, doch zij bezat tevens een hoog dak van vijf verdiepingen, dat haar vanuit zee duidelijk herkenbaar maakte. De muur om het moskeeterrein had een poort in de trant dergene, die men later te Kali-Njamat aantrof. Het uiterlijk dezer moskee werd reeds in een artikel in Djawa (XV, 1936 p. 160) besproken, terwijl gepoogd werd haar betrekking tot latere en vroegere moskeegebouwen vast te stellen in een artikel in Indonesië ( $I$, p. 289-305).

De toegang tot dit heiligdom was de Christenen onverbiddelijk ontzegd. Wouter Schouten hangt een vermakelijk verhaal op van de opschudding onder de Javanen verwekt, toen hij en zijn gezelschap er een blik in poogden te slaan ( $I, 38$ ). De bevolking heette n.l. zeer fanatiek; de ,papen" moesten soms door een geschenk in een goede stemming worden gebracht.

\section{De positie der Nederlanders in Japara.}

In theorie verschilde de positie der Nederlanders te Japara slechts in zoverre van die der Javanen, dat eerstgenoemden ook de orders van de Gouverneur-Generaal moesten nakomen. Immers, een dienaar van de tumenggung Mataram Wira-Djaja zegt tegen de resident Luton: „Ghy behoorde, soo lang ghy hier syt, des Sousouhounangs ordre soo wel nae te komen, als de ordre van d' heer Generael" (D. 5 sept. 1663).

De gouverneur van Japara, ,sustineerde oock nogh seer sterck, dat hem het commando ende gebiet over de Nederlanders soo wel toequam, als over zyn eygen volck, de Javanen, zynde... gefondeert op deze twee redenen: 1e, omdat de Javanen tot Batavia ... onder de Regeringe stonden, 2e, omdat hem de Sousouhounangh hadde gestelt tot regent en gebieder over alle natien on volckeren tot Japare, niemandt uytgesondert" (D. 13 nov. 1669).

Merkwaardig is in dit opzicht een vroeger schrijven van deze zelfde heer, waarin hij mededeelt, dat de Sunan hem tot hoofd over Japara had aangesteld, om ,'t selve als hooft ende over alle natiën, 't sy Javaenen, Maleyers, Chineesen, swarten ...; dogh de Hollanders, die in de logie alhier syn, en staen onder myn commando niet". En nu komt een wonderlijk verzoek: „Maer, soo 't broeder gelieft ende my ordre wilde geven, soo soud'ick deselve oock... regeeren, en soo 't broeder niet en gelieft, ick en sal my daer gansch niet mede bemoeyen". 
M.a.w. hij dringt bij de Hoge Regering Javaans beleefd op een erkenning van zijn bestuursmacht over de Nederlandse posthouders aan (D. 5 juni 1666 p. 85--86).

Hoever deze macht zich bij tijden kon uitstrekken, bewijst het ingrijpen der opperstrandheren Wira en Wira-Djaja in 1653. Volgens deze machtige heren was het de resident van Japara niet vergund, om op eigen houtje naar Batavia te vertrekken, tenzij expres door de Hoge Regering ontboden, of door de Sunan daarheen gezonden. Als hij door de Hoge Regering ontboden was, diende de Sunan daarvan eerst verwittigd te worden, opdat men zich niet zou gedragen als eertijds Sr. Schouten, de eerste resident, die de eer had genoten 's Vorsten aangezicht te aanschouwen en belast was, om nevens de Javaanse gouverneur ,alles wel te dirigeeren”, maar door wie ,andermale faulte wierde gepleecht". Daarom mocht de resident niet zo maar heen en weer naar Batavia reizen, zelfs niet in gezelschap van des Sunans gezant tg. Paṭi (Volsch a/d H.R. dd. 8 apr. 1653 T.B.G. LXI, 494).

In de praktijk kwam natuurlijk van deze in de ogen der Compagnie overdreven pretenties niet zo heel veel terecht, wat ongetwijfeld wrijving en wrevel moet veroorzaakt hebben.

Anderzijds werden de Nederlanders volstrekt niet op één lijn met de andere onderhorigen en vazallen van de Susuhunan gesteld. In de grond van zijn hart koesterde de Vorst een zekere eerbied voor hen, wellicht zelfs vrees. Doch in ieder geval waren zij hem welkom als vermeerderaars zijner schatten, en, wat bij een Javaans vorst zeer zwaar woog, van zijn aanzien.

Voor een Nederlands gezantschap had de Sunan daarom een bijzondere voorliefde, „om, soo het schynt, syn aensien ende respect omtrent de gebuyrvolken daermede te vergrooten, alsoo hy het dan de naem van hommagie weet te geven, om haer te bewegen van gelyke te doen". Daar de Sunan de Compagnie en haar geschenken brengende gezanten toch niet kon missen, hield de Hoge Regering zich soms ",bot" en veinsde ,syn meyninge niet te verstaen” (d. J. VI, 99). Deze trotse onverschilligheid der Compagnie hinderde de Vorst ernstig. Ook het vrijmoedig gedrag der gezanten, die hij bijna nooit zo honds dorst te behandelen, als hij het ambassades van Indonesische hoven placht te doen, zullen hem bijwijlen geprikkeld hebben, door hun zich zelden verloochenende vrijmoedigheid. Hij moet het gevoel gehad hebben, tegenover een mogendheid te staan, waartegen hij met de traditionele machtsmiddelen weinig of niets vermocht. Hierin lag de kiem van een conflict. 
Aan de andere kant heeft het wijs en tactvol optreden van de gezant Rijklof van Goens er veel toe bijgedragen om de verhouding tussen de Sunan en de Compagnie te verbeteren. Hij heeft in Mataram door zijn vijf gezantschapsreizen (1648-54) een aangename en heilzame indruk achtergelaten, waardoor de latere samenwerking tussen het Mataramse hof en de Hoge Regering te Batavia werd voorbereid.

\section{De eerste residenten. $1651-55$.}

Dirck Schouten, de eerste resident, is niet lang in Japara gebleven. Reeds na enige maanden werd hij naar Batavia ontboden, om met een gezantschap naar Perzië te gaan (H.R. 31 juli 1651 T.B.G. LIX, 450). Het beheer der loge werd overgelaten aan de onderkooplieden Bernard Volsch en Jacob Backer (H.R. 22 sept. 1651 T.B.G. LIX, 458). Dit was geen gelukkige keus.

Spoedig zag de Hoge Regering zich genoodzaakt in te grijpen. In dec. 1651 zond zij de opperkoopman J. Goossens met een memorie als commissaris naar Japara, vanwaar hij dadelijk Volsch verwijderde (H.R. 5 dec. 1651 T.B.G. LIX, 467); Backer mocht voorlopig nog blijven. In Batavia slaagde Volsch er blijkbaar in zich te rechtvaardigen. Bij resolutie van 16 febr. 1652 werd besloten hem als opperhoofd, voorzien van een degelijke instructie, over het comptoir Japara aan te stellen; Backer zou elders te werk gesteld worden.

Aldus keerde Bernard Volsch zegevierend in Japara terug; zijn secunde werd Barent Hunius. Op den duur moet deze schikking de Hoge Regering berouwd hebben. Met Volsch ging het n.l. van kwaad tot erger. Tijdens het bezoek van de ontvanger-generaal Hendrick van Gent aan Japara in juli-augustus 1653 bevond deze, dat op de persoon van Volsch "niet anders te seggen viel, als dat hy tot den dranck genegen ende gedebaucheert van vrouwen was”. Zijn ,bboeckjes” werden wel in orde bevonden, maar de onkosten vielen wat te hoog. Hij had zich niet ontzien een ,concubine publyckelyck meer dan een jaar in Comps. wooningh te onderhouden". Aan zijn successeur werd dit streng verboden (D. 4 sept. 1653). Deze, de onderkoopman Pieter Elsevier, nam slechts tijdelijk waar, tot Volsch begin nov. 1653 weer als opperhoofd terugkeerde. Sommige lieden zijn waarlijk onuitroeibaar. Een bedenkelijk teken was, dat Elsevier hem geen transport wilde doen (de zaken overdragen) eer de vloot van de kommandeur de Vlamingh van Outshoorn ter rede verscheen (D. 24 nov. 1653). Hij wilde dus getuigen hebben. Overigens nam Volsch aan alle gezantschappen deel, 
was dus wel toonbaar. Ten slotte was de kruik lang genoeg te water gegaan. Bij resolutie van 28 sept. 1655 werd hij naar Batavia opgeroepen, om „meerder questies voor te comen”. Met zijn secunde Hunius maakte hij n.l. ruzie, beiden betichtten elkander van knoeierijen; als ondeugdelijk instrument is hij ten slotte naar patria teruggezonden.

\section{De tolken voor het Javaans.}

Twee personen, die in de Javaanse gevangenschap de Javaanse taal geleerd hadden, speelden in het latere verkeer met de Matarammers een zekere rol, t.w. Michiel Zeeburgh en Matthijs Pietersen. Beiden behoorden tot het volk van de "Westzanen”, dat in 1632 verraderlijk gevangen genomen werd en welks leider, de Javaanskundige Antonie Paulo, zich tijdens de jarenlange krijgsgevangenschap zo onderscheiden heeft (vide: „Sultan Agung” passim).

Michiel Zeeburch, „een van de laest verloste gevangenen” (v. Goens 95), was reeds in 1642 in Mataram uit de boeien geraakt, dus Moslim geworden. Vermoedelijk is hij daarna met een Javaanse getrouwd. Hij zal tot die drie Nederlanders behoord hebben, welke pas in 1651 met hun zes kinderen bevrijd werden (v. Goens 89). Dadelijk trad hij in dienst der loge te Japara als tolk. Zijn gage werd op 8 tot 10 realen gesteld (H.R. 13 juli 1651 T.B.G. LIX, 449). Het volgende jaar gebruikte men hem als spion in Samarang (T.B.G. LX, 160). Reeds in 1653 verliet hij de dienst der Compagnie (Bat. 30 sept. 1655). Twee jaar later wordt hij „den Hollandtsen Javaen" genoemd en licht de resident in omtrent de plannen van de Sunan. Blijkbaar dankt hij deze wijsheid aan zijn meester, tg. Pati, in wiens stad Djuwana hij woont. Daar helpt hij in 1656 enige Nederlandse schipbreukelingen (Hon. Naber, Marineblad XXV 1910-11 p. 18 en vlg.). In 1659 ontmoeten we hem voor het laatst als bode voor tg. Pați (D. 28 febr. 1659 p. 39); daarna verliezen we hem uit het gezicht.

Matthijs Pietersen is blijkbaar géén renegaat geworden, want in 1641 zucht hij nog in de boeien. Hij treedt wel als tolk op, maar dan bij gewichtige gezantschappen, b.v. het 3e en $4 \mathrm{e}$ van Van Goens (1651 en 1652). Daarbij schijnt hij zich vooral tot het vertalen uit het Javaans beperkt te hebben, dat hij bij machte is te beoordelen (v. Goens 89). Hij begrijpt de woorden uit de mond van de Sunan (v. Goens 121), en weet ,wonderlicq met dat volck... om te gaen" (H.R. 11 oct. 1651 T.B.G. LIX, 466).

Meermalen wordt hij daarom met bijzondere opdrachten aan 
Javaanse aanzienlijken vereerd, aangezien hij ,in de Javaense tale prompt is, ende vryposticheyt heeft, om by de groote zyn woort redelyck te doen" (H.R. 26 febr. 1652). Bij Van Goens' laatste gezantschap in 1654 wordt de afwezigheid van een tolk, die ,in de Javaence manier seer affabel zij ende besondere bequaemheyt heeft" (v. Goens 139), pijnlijk gevoeld.

De Bataviase Kerkeraadsnotulen van 5 sept. 1650 noemen hem „basaerwachter”. In 1651 is hij boomwachter (T.B.G. LIX, 466), bezit enig kapitaal en een eigen sloep (v. Goens 124 noot 1). Begin 1653 heet hij onderkoopman.

Omstreeks 1654 moet hij uit de dienst der Compagnie getreden zijn. In 1656 bevindt hij zich in Achter-Indië als „,den Batavischen borger Thijs Pietersse van Gardingh". Hij vaart op Kambodja als vrijkoopman (D. 1 apr. 1657), vanwaar hij met rijst en gedroogde vis terugkeert (H. P. N. Muller, De O.I. Comp. in Cambodja en Laos p. 363-64). Zijn trouw aan het geloof bewijzen zijn relaties met de Gereformeerde Kerk. In 1650 pleit hij voor ,3 kinderen, geteelt van een Duijtsman bij een Javaensche vrouwe", die wel zijn godsdienst schijnt verloochend te hebben, maar ,in zijn uijterste een goede belijdenis des geloofs gedaen hadde" (Notulen 5 sept. 1650). De kinderen worden dus ,naer den aardt der liefde tot de H. Doop toegelaten". In 1655 bezit hij een slavin, die op haar belijdenis de doop wenst te ontvangen (Notulen 6 sept 1655).1

Wanneer hij in 1659 tot diaken gekozen wordt, maakt hij bezwaar, op grond van een voorgenomen reis naar Borneo (Notulen 19 en 23 jan. 1659). Toch zal men hem deze bediening opdragen. Wegens zijn veelvuldige bezigheden en aanstaand vertrek naar het vaderland, wordt hij gelicentieerd (Notulen 26 jan. 1660). Een berouwvol renegaat zal men niet licht tot ambtsdrager verheffen.

Gezien zijn bekwaamheid en positie heeft Kern's hypothese (B.K.I. CXIII 1957 p. 205), dat hij Van Goens over zeden en overleveringen der Javanen ingelicht heeft, inderdaad veel voor.

De bouw der eerste jachten. 1651-52.

Een voorname reden voor de Compagnie, om in Japara een loge te hebben, was de goede gelegenheid om er jachten te bouwen, die „ten

1 Daarentegen wordt zijn vrouw, Magdalena, in dat jaar wegens krakelen met de echtgenote van luit. Michiel Willemsz voor de Kerkeraad gerocpen $\mathbf{Z i j}$ verschijnt echter niet (Notulen 27 dec. 1655). 
hoogste benodicht" waren (T.B.G. LX p. 152). Daarom bevatte de instructie van de eerste resident, Dirck Schouten, reeds een en ander over scheepsbouw (dd. 13 juli T.B.G. LX, p. 447). Na een verkenning te Rembang overtuigde Schouten zich van de goede gelegenheid en de lage prijs, zodat ten minste drie jachten van 70 tot 80 last besteld werden (Res. 28 juni 1651). Als scheepstimmerman werd Aert Pleunen Moot met zes timmerlieden aangesteld. Men hoopte deze voor Amboina bestemde vaartuigen tegen nov. 1651 klaar te krijgen; het werd echter een jaar later.

Vermoedelijk nam men van "contractanten" (Chinezen?) een aantal Javaanse scheepstimmerlui in dienst tegen een overeengekomen prijs (H.R. 22 sept. 1651 T.B.G. LIX, 458-59), doch na een tijdje klaagden deze contractanten over de lage beloning. Geen wonder, daar het „heel een ander ende swaerder werck" was, „als by haar in gewoonte". Zij moesten daartoe "minnelijk" geanimeerd worden. Bij tijdige voltooiing werd een ,satisfactie" beloofd.

Groter last bezorgden de Javaanse overheden, al had men ook tg. Pați en zijn broeder Tjitra-Nala in de arm genomen (T.B.G. LIX, 448), o.a. door ondershandse of openlijke geschenken. Het houtwerk kwam traag af, dank zij enige „kale schrobbers met gepretendeerde autoriteit, wie de hand gezalfd (moest) worden" (Jap. 5 dec. 1651 T.B.G. LIX, 467-70). Vermoedelijk waren deze spelbrekers de tugurs der opperstrandheren. Soms werden de werklieden de Nederlanders onthouden en de afbouw verhinderd (Memorie Volsch dd. 20 febr. 1652 T.B.G. LX, 139). Men zocht recht bij de hoogste instantie, n.l. bij de Sunan, die op aandringen van tg. Pați en Patra-Menggala het voltooien der vaartuigen goedkeurde.

Eindelijk gelukte het twee jachten te water te laten; steven en kiel van het derde werden naar Batavia gezonden. De eerste twee zouden zo snel mogelijk in zo'n toestand gebracht worden, dat ze half voltooid, opgepropt met hout naar Batavia konden gesleept worden (H.R. 17 mei 1652 T.B.G. LX, 152). Pas Van Goens gelukte het, ze tijdens zijn 4e ambassade behouden bij Onrust te brengen. Nadien werd de scheepsbouw voorlopig gestaakt.

Beheer der stranden. 1648-51.

Werpen wij thans een blik op de wijze, volgens welke de Matarammer de Pasisir bestuurde.

In 1648 was het voorschrift van kracht, dat alle vaartuigen, die Java's 
Noordkust verlieten, op Japara moesten vertold worden (v. Goens 70-71). Echter werd het vaak ontdoken, wat tot geharrewar tussen de strandheren leidde.

Om dit te beëindigen beval de Vorst, dat alle zeehavens „haer eijgen gerechticheijt" zouden ontvangen, en „reeckeninge aen den tommagon Mataram doen". Dit was een overwinning voor de gouverneurs buiten Japara, m.n. de gebroeders Suta en Angga-Pradja te Samarang, die zich trouwens meer aanmatigden, dan hun rechtens toekwam. Spijtig merkte de gouverneur van Japara, Wira-Setia op, dat ze zijn post begeerden, waartegen hij, als oud man, geen bezwaar had. Zij zouden hem echter niet vervangen.

Hoe lang dit stelsel van afzonderlijke tollen voor elke haven heeft stand gehouden is niet duidelijk; waarschijnlijk tot 1651, aangezien dan ook op ander gebied een grote ommekeer plaats vindt.

In het begin van dat jaar blijkt Wira-Setia gedegradeerd en overgeplaatst naar Kenḍal. „d'Andere resterende Zee-gouverneurs waren mede in decadentie, soodat naer apparentie binnen corten tijt pertije stonden over de klingh te dansen" ( $v$. Goens 79-80). Verder werd vernomen, dat ook de tumenggung Mataram in ongenade gevallen was, beroofd van zijn 6000 onderhorigen en veroordeeld om zich als een ,gemeen Edelman met weijnich swiete te erneren". Weliswaar was dit ook met Angga-Pradja het geval, doch deze ,presumeerde vastelijck, dat weder in de gunst des Conincks soude comen". Dit is ook gebeurd.

Wij merken dus op, dat personen, belast met de uitvoering van het vorige stelsel, t.w. de strandheren en de tg. Mataram, gelijktijdig de gunst des Sunans verbeurden. Voldeed het systecm niet meer? Van een nieuw stelsel wordt evenwel voorlopig niet gesproken.

In plaats van $\mathrm{kj}$. Wira-Setia werd $\mathrm{kj}$. Patra-Menggala over Japara aangesteld, maar het broederpaar Angga-Pradja en Suta (verhoogd tot tg. Nata-Airnawa van Pați), schijnt ook heel wat in Japara te zeggen te hebben. De sterke invloed van deze laatste, die sterk Compagniesgezind is, valt samen met de best geslaagde Nederlandse ambassade van 1651 en de stichting ener Nederlandse loge in Japara.

\section{Grieven van de Sunan.}

Terwijl de Nederlanders in 1651 zich nog in de gunst van de Matarammer mochten verheugen, is dat tijdens het gezantschap van 1652 niet meer het geval. Ongetwijfeld waren door de stichting der loge de kansen op conflicten toegenomen. Het vrijmoedig optreden der 
Nederlanders aan de kust, het houtkappen in het Krawangse, de scheepsbouw te Rembang, het rijst kopen en laden in Japara waren feiten, die door Compagnies tegenstanders in een ongunstig daglicht konden worden gesteld.

Bovendien is tijdens de stichting der loge geen afspraak omtrent prijzen of tollen gemaakt. Gevraagd mag daarom worden, of de Sunan van de aanwezigheid der Nederlanders te Japara wel enig voordeel genoot. De gouverneurs zullen zeker niet te kort zijn gekomen, mèt of zònder uitvoerrechten, aangezien zij zich als leveranciers van hout en rijst opwierpen. Daarom zal de Vorst geen of weinig baten van de Nederlandse loge gehad hebben, in tegenstelling tot de strandheren, wier rijkdom en voorspoed toenamen. Dit moet de begeerte van de Sunan hebben opgewekt.

In 1651 ondernam hij een volkstelling, waarvan Batavia gaarne doel en uitslag vernam (H.R. 9 oct. 1651 T.B.G. LIX, 643). Het doel kan moeilijk anders dan een hoofdgeld geweest zijn. Alle huisgezinnen werden onder heren gesteld, zo verhaalt Van Goens (v. Goens 202) en ieder moest een reaal van achten aan belasting opbrengen; indien zij daartoe niet bij machte waren, dienden ze 10 grote bossen padi te leveren, die in alle dorpen aan 's Vorsten ontvangers geleverd moesten worden. Ze werden tot rijst gestampt en naar de zeehavens van ieder gouvernement gebracht. De opbrengst werd vervolgens aan 's Vorsten schatmeesters uitbetaald en naar boven gebracht. Aldus hoopte de Sunan niet bij zijn rijke strandheren ten achter te blijven.

Volgens dit plan zou ,niemant zijner onderdaenen ... buijtenslants" mogen varen. Daarentegen zouden de buitenlanders zijn land komen bezoeken, daar hij zeer goed wist, ,'t selver de spijsekamer van Batavia ten principalen te wesen". Aldus zou hij alles, wat de Nederlanders aanbrachten, aan zich trekken, ,sonder dat ijmand der onderdaenen een stuijver mach handelen".

Men zal dus de Sunan in 1652 zien optreden tegen zijn onbetrouwbare strandheren, die hij onder nauwkeurige controle wilde brengen; doch tevens wenste hij de z.i. al te grote vrijheid der Nederlanders te beperken. Daarbij had hij zowel de Compagnie en haar dienaren als de z.g. vrijburgers op het oog. Vooral deze laatsten ontsnapten aan ieder toezicht; vandaar zijn wens, dat voortaan op ieder burgervaartuig een vertegenwoordiger der Hoge Regering aanwezig zou zijn. Een onmogelijke eis! Bovendien hoopte hij dusdoende van die vertegenwoordigers nog geschenken te krijgen; van de vrijburgers behoefde hij in dit opzicht niet veel te verwachten. Overigens lijkt het vanzelfsprekend, dat waar 
de Vorst van zijn kant de handel normaliseerde, de Compagnie van haar zijde hetzelfde zou doen.

Zijn einddoel zou het vergaderen van schatten zijn, want, zo meende Van Goens, ,'t seecker ende gewis sij, dat sijn concept daertoe leijt, (dat) niet eene van sijne slaeffse onderdaenen gelt sullen besitten" (v. Goens 115).

Door dit vorstelijk handelsmonopolie, aldus betoogde echter onze gezant tijdens zijn vierde reis, zou ,de neringe verslappen en Syn Mayt. by gevolge niet wel... vaeren" (v. Goens 111). Zelfs zou hij toentertijd onder de persoonlijke aandacht van de Sunan gebracht hebben, ,dat hy behoorde zijn onderdaenen te laten varen om rijck te worden, ende dat hij dan van hun conde trecken grooter gerechtichheeden, ende zijn land mettertijd soude rijck werden" (v. Goens 202). De hooghartige Vorst had hem daarop geantwoord: „Mijn volck heefft als ghijlieden niets eijgen, maer alle 't hunne comt $\mathrm{mij}$ toe; ende sonder strenge regering soude ick geen dag Koninck zijn" (v. Goens 202). Merkwaardige en betekenisvolle woorden, waarbij men, om ze ten volle te waarderen, de omstandigheden dient te kennen, waaronder ze uitgesproken werden!

Met invoering van dit handelsmonopolie was een tweetal opperstrandheren belast, welks bedrijvigheid wij thans nader onder het oog moeten zien.

\section{De twec opperstrandhcren. 1651-57.}

Ten minste sedert het jaar 1652, wellicht reeds eerder -- Wira-Djaja wordt al een jaar vroeger vermeld - oefenden twee opperstrandheren, genaamd $\mathrm{kj}$. Wira en $\mathrm{kj}$. Wira-Djaja, het toezicht over de stranden uit. Tijdens Van Goens' bezoek in oct. 1652 worden zij voor het eerst samen genoemd als 's Vorsten ,grootste Stadthouders over de Noortzyde syner landen" ( $v$. Goens 111). Hun taak is toe te zien, dat vorstelijke bevelen in hun gebied nageleefd worden, t.w. kj. Wira in de westelijke, kj. WiraDjaja in de oostelijke Pasisir. De eerste wordt n.l. in één adem genoemd met kj. ng. Wangsa-Radja van Samarang, de andere met tg. Pați (v. Goens 160-61).

Onder hen staan dienaren, die officieel tugurs (Toegers: D. $7 \mathrm{dec}$. 1656 p. 33) heten; dezen treden herhaaldelijk aan de kust tussen beiden. Onderworpen aan de strikte bevelen van 's Vorsten naaste dienaren, staan $z i j$ een te grote vrijheid der strandheren in de weg. Ook de Nederlanders zien hen ongaarne en laten zich soms in krasse termen over hen uit (Volsch dd. 5 dec. 1651 T.B.G.LIX 467-70; idem 6 mei 
1652 T.B.G. LX, 151-52). Bijwijlen moet men hen omkopen.

Op bevel uit Mataram ziet men hen zich van de ene naar de andere plaats spoeden, b.v. drie hunner van Japara naar Krawang, ter regeling der houtleveranties (D. $19 \mathrm{mrt}$. 1653). Of wel er daagt een expresse bode der opperstrandheren in Japara op (D. 6 mei 1653 p. 47). Zelfs de strandheren moeten voor hen bukken. Tijdens tg. Patị's uitzending als gezant naar Batavia informeert de Sunan bij kj. Wira, ,of hij hem op syn vertreck niet belast hadde spoedige reyse te vervorderen, om S. M. des te eer rapport te doen" (D. 6 mei 1653 p. 48). Soms verwaardigen zij zich om naar de stranden af te dalen (D. 12 apr. 1653), ten einde 's Vorsten toorn aan de resident te kennen te geven over te traag verzonden 1000 lasten rijst. $\mathrm{Zij}$ bezichtigen loge en schepen. $\mathrm{Na}$ een week vertrekken zij weer. Een half jaar later verschijnt kj. WiraDjaja alleen in de loge (D. 8 oct. 1653). De Compagniesgezinde tg. Pati wordt door hen „soo wat geschrobbeert” (D. 25 apr. 1653). Van de resident trachten zij geld los te krijgen. Daarentegen pleegt men zich ook wel met klachten tot hen te wenden (D. 8 febr. 1653).

Een beperking van het gezag der tugurs is voor de strandheren een grote opluchting, zoals wanneer Krawang aan tg. Pați wordt overgedragen ,tot een donatie... om alle voorcomende saecken... naer 's lands wetten aff te doen", zodat hij er geheel alleen verantwoordelijk voor is (T.B.G. LXIII, 536). De tugurs worden door tg. Patị's broeder, Tjitra-Nala vervangen (D. 25 juli 1653). Maar nog groter is de vreugde, wanneer zij geheel van het toneel der stranden verdwijnen, althans voorlopig, in 1657.

De invoering van dit nieuwe stelsel van controlerende opperstrandheren met hun zwerm van dienaren in 1651 bracht echter voor de Nederlanders tal van beperkingen met zich mede.

\section{De handelsbelemmeringen. 1652.}

Belemmeringen in de handel ondervonden de Nederlanders bij de afvoer van hout en suiker. Een expres gezonden schip mocht in Japara geen lading innemen, omdat het geen schrijven der Hoge Regering kon vertonen (H.R. 11 oct. 1651 T.B.G. LIX, 465). Deze klaagde daarover bij de ,gebieders van Japara", die er Matthijs Pietersz. op af stuurden. $\mathrm{Zij}$ achtte dit in een brief aan de residenten te Japara een "groote opgeblasentheyt van die coele schrobbers". Daar het schip, een fluit, nog met de retourvloot mee moest, gaf de Hoge Regering toe en zond een briefje met geschenk. Desnoods moest de fluit maar leeg terug, opdat 
die gouverneurs zouden zien, dat Batavia niet zoveel werk van de gevorderde houtwerken maakte (T.B.G. LIX, 466-67).

Dat deze belemmeringen op bevelen uit de hofstad berusten, blijkt het duidelijkst uit de hinder, ondervonden bij het traag afbrengen der houtwerken en het verhinderen en verbieden der scheepstimmerlieden, te danken zijnde ,ten principalen door toedoen van eenige kale schrobbers, die met gepretendeerde aucthoriteyt van boven comende, een plasdanck neffens wat hantsalvinge soecken te behalen" (H.R. 5 dec. 1651 T.B.G. LIX, 468). In het voorjaar van 1652 komen veel schepen onvolladen terug, waarnaar de Hoge Regering beveelt een onderzoek in te stellen (H.R. 18 apr. 1652 T.B.G. LX, 151).

Op 6 mei 1652 antwoordt de resident B. Volsch. Hij schrijft over „canaelie", die hem om de tuin leiden (T.B.G. LX, 151-52), waarmede hij ongetwijfeld de dienaren der opperstrandheren, de tugurs bedoelt.

Ten slotte werd de houtkap en houtafvoer aan de rivier van Krawang (Tji Tarum) belemmerd. Javaanse dienaren van de Vorst hadden daar zelfs hout van de Compagnie in beslag genomen. Het vraagstuk van de grensaanduiding, waaraan bij het vredesverdrag van 1646 niet gedacht was, werd nu dringend. Het gerucht maakte van de Mataramse bemoeienis met het Krawangse reeds een derde grootscheepse aanval op Batavia, waartoe een 10 tot 12.000 man de rivier zou zijn overgestoken.

$\mathrm{Al}$ deze maatregelen kan men zien als verweer tegen een als aanmatiging beschouwde handelsbedrijvigheid der Compagnie. Vooral het optreden der lagere goden - burgers en Chinezen - schijnt geprikkeld te hebben.

Doch niet slechts tegen de Compagnie en haar dienaren of onderdanen keerde zich de actie der beide opperstrandheren, ook 's Vorsten eigen onderzaten, de Javanen, werden niet met rust gelaten, opdat „niemant de waerde van een reaal rijs ofte houtwerck uyt sijn lant sal vervoeren, sonder dat hij (de Sunan) van 't gelt verseeckert sij in sijn casse te comen" (v. Goens 114). Er wordt zelfs opgetreden met terugwerkende kracht.

Geld, uitbetaald aan arme Javaanse scheepstimmerlui voor het bouwen van Compagnies jachten in Rembang, werd van hen opgeëist; hetgeen de houtverkopers te Samarang in 1651 en 1652 van de Compagnie ontvangen hebben, moeten zij aan de "oppassers" van de Sunan afdragen, „ofte werden ellendich getracteert” (v. Goens 114). De padi, die van het veld komt, wordt aan deze dienaren overgeleverd en tot ,rijs gemaeckt", dus gedorst en gepeld. Ieder huisgezin moet n.l. 25 bos (of 10 grote bossen) opbrengen, zodat de vorst op 500.000 maal 25 bos 
rekent (v. Goens 202). Van hetgeen er overschiet mag de tani zien rond te komen.

In het licht van 's Vorsten monopolistisch streven dienen wij ook het uitzetten der Engelsen, zonder opgaaf van reden, te zien, op 23 junı 1652 (T.B.G. LX, 155).

Officieel werden des Sunans grieven overgebracht door een tweetal eenvoudige dienaren, si Wangsa-Pada en si Tjitra-Nala - dit si zegt al genoeg - die op 24 juni 1652 een klein briefje van hun heer overhandigden, luidende, dat de Vorst besloten had de uitvoer van hout en rijst te staken, zonder dat hij iets tegen de Compagnie had. De rest zouden de boodschappers wel vertellen.

Ondervraagd deelden beide heren mede, dat het uitvoerverbod tegen Mataram's oude vijand Bantam bedoeld was, hetwelk, naar verluidde, zijn rijst en hout uit Batavia ontving. De Compagnie kon wel rijst krijgen, mits de Gouverneur-Generaal telkens iemand zond, om over de gewenste hoeveelheid te contracteren en die dan te kopen. De ware reden, het handelsmonopolie, werd dus verzwegen. Voorts vroegen de briefdragers, wanneer er weer eens een gezant kwam, wie er benoemd was. De moeson liep ten einde!

De Hoge Regering vermoedde, dat de Vorst zich door ,partie onser wangunstige... het hoofd laet vol blasen", maar besloot toch in te binden. Tijd ontbrak om voedsel van elders te ontbieden, en beducht voor schaarste, benoemde zij haastig de kapitein der burgerij, Hendrick van Gent, met als tolk, voor de vierde maal, entjik Ahmat.

Gelukkig bezat de Compagnie ook bondgenoten aan het hof: tg. Paṭi Nata-Airnawa en de gouverneur Patra-Menggala hadden er tegen de nieuwe politiek gesproken. Beiden heetten vrienden der Compagnie en bijzonder Patra-Menggala was zeer behulpzaam bij het laten uitvoeren van houtwerken in voorraad (H.R. 17 mei 1653 T.B.G. LX, 151-52).

Daarom zond men naar tg. Pati, zo mede naar kj. Wira-Djaja, wiens naam hier voor het eerst verschijnt, de tolk Matthijs Pietersen met een briefje. Hij diende de komst van de Nederlandse ambassadeur aan te kondigen, gezien de ,veelvoudige vreemde ende diverse geruchte..., om verseeckering van de Mayts. humeur ende genegentheyt... te mogen erlangen" (T.B.G. LX, 160).

\section{Het 4e gezantschap van Van Goens. 1652.}

De groeiende geruchten, de algemene ontsteltenis, gepaard met een run op Compagnies sober voorzien rijstmagazijn, noopten de Nederlandse gezant van Gent om ontheffing van de eerst aanvaarde opdracht 
te verzoeken, terwijl de Maleier liever verkoos zijn ambt als hoofd zijner landgenoten neer te leggen, dan zijn leven in Mataram op het spel te zetten. Vooral dit ontslag maakte indruk, daar men deze Indonesiër omtrent de verborgen bedoelingen van de Matarammer beter onderricht achtte dan het bestuur der Compagnie.

Tot gezanten werden nu aangezocht Rijklof van Goens en de gewezen opperchirurgijn des Kasteels, mr. Pieter Andreas. Beiden verklaarden zich bereid, zij het de eerstgenoemde met een zwaar hart. Bovendien gingen de Japarase resident Bernart Volsch en de bekwame tolk Matthijs Pietersen mede. Het geschenk werd aanmerkelijk vergroot, van 6980 op 60.000 gulden, waarbij dan nog een paar stukken geschut kwamen. Pas op 18 sept. 1652 kon men vertrekken. Behalve de rijsttoevoer kreeg Van Goens nog een kwestie met de Portugese handelaar Dom Francisco Viera in Makassar te behandelen.

Bij slot van rekening is alles erg meegevallen. Aanvankelijk heerste nog spanning, waartoe het losbreken van een van Van Goens' paarden tijdens hun eerste nacht ten hove nog bijdroeg. Dit veroorzaakte een paniek, zowel bij Javanen als Nederlanders, die zich reeds op het ergste voorbereidden.

Op de eerste audiëntie raakte Van Goens de rijstkwestie nog niet aan, doch vermaakte de Sunan met de kunsten van goochelaars en de tonen van een meegebracht orgeltje. De Vorst lachte, waarmede de gezant het pleit reeds half had gewonnen. Toch moest hij nog vechten voor de volgende regeling: een voorlopige grensafbakening bij Krawang met vrije houtuitvoer uit die rivier; opening der zeehavens en onbelemmerde wederzijdse handel; verlof om in Japara hout en rijst op te slaan, met het recht om ten hove te klagen, als dit belet werd. Ook de zaak Viera werd tot wederzijdse voldoening geregeld.

Doch om zijn schepen vol rijst te laden, moest Van Goens nog een hele kustreis maken, wilde hij niet met lege ruimen in Batavia verschijnen. De beloften waren slechts gegeven, omdat deze psychisch afwijkende Vorst Van Goens openlijk niets dorst te weigeren, maar zij werden nimmer ingelost. Er waren trouwens nog ongunstiger voortekenen. Wel was een rijk Javaans tegengezantschap met veel rijst toegezegd, doch Van Goens voorzag reeds, dat het enkel om geschut te doen was. De uitkomst gaf hem gelijk.

Het Javaanse tegengezantschap. 1653.

Gedurende het jaar 1653 nam de spanning niet af. De Javanen vroegen één reaal meer voor de rijst, dan Van Goens bedongen had. 
Van vrije handel was geen sprake en in Krawang begon het geharrewar opnieuw. Van Goens moest er heen en kwam tot een voorlopige regeling. De lurah's zouden om nadere instructies schrijven; zij hadden geen machtiging iets te beslissen.

Verder werd de tolk Matthijs Pietersen naar Mataram gezonden met geschenken en brieven. Hij bracht het zover, dat de rijst iets vlotter werd geleverd, terwijl hij uit Krawang, waar hij zelf heen moest trekken, wat hout wist los te krijgen. Aan de stranden was men druk doende met het inzamelen van 1000 last rijst, die het beloofde Javaanse gezantschap zou komen aanbieden. De opperstrandheren zelve verschenen er voor aan de kust ter bevordering van het inzamelen, z.g. omdat Batavia zo'n ernstig rijstgebrek had. Natuurlijk sprak de resident dit tegen: er was reeds rijst uit Siam en Arakan aangevoerd.

Op 14 apr. 1653 kwam de eerste Javaanse gezant ter rede van Batavia, de bekende Hollandsgezinde tg. Pati $i$, vier dagen later gevolgd door de overigen, in 130 vaartuigen, met 3500 tot 4000 man. Ongetwijfeld was dit als demonstratie bedoeld. De komst van deze armada veroorzaakte geen kleine opschudding. Daarom bracht de Hoge Regering ook haar ganse macht op de been, zodat het in Batavia een drukte van belang was.

De meegebrachte brief der gezanten bevatte het verzoek om geschut, waarmede de Sunan zijn oorlogsprauwen wenste te voorzien. Op 13 mei toonde men hun het artilleriemagazijn, waar een dertigtal stukken - niet de beste - voor hen uitgestald lagen. Tevens werden de deuren van het rijstpakhuis geopend, opdat zij zich konden verbazen over de daar aanwezige 5000 last rijst, alles uit Koromandel en van elders aangevoerd, zonder ook maar één korrel Javaanse rijst. Dit konden ze hun meester rapporteren.

Op de 18e mei 1653 overleed de gouverneur-generaal Reyniersz en de volgende dag schreden de Javanen mee in de begrafenisstoet, tussen de Raad van Indië en de rechterlijke macht in. Van Goens liep naast tg. Pați.

Toch was men wederzijds niet erg tevreden. De Javanen niet, omdat zij voor hun rijst maar 30 i.p.v. 50 realen kregen: de marktprijs was intussen gedaald. De Nederlanders evenmin, omdat de Javanen ondershands schietgeweer opkochten, zelfs oude geweerlopen. Op 28 mei 1653 geleidde Van Goens hen beleefd uit. Met de volgende ambassade naar Mataram was niet hij, maar Hendrick van Gent belast, wie het vorige jaar de moed in de schoenen was gezonken. 
Het gezantschap van Van Gent. 1653.

In gezelschap van de koopman Johan Grevenraet en de onderkoopman Pieter Elsevier vertrok Van Gent op 11 juni 1653 naar Japara, waar hij een week later door de vooruitgereisde Javaanse gezanten verwelkomd werd. Op 30 juni kwam hij in Mataram aan, waar hij zeer statig door de Vorst werd ontvangen. Ditmaal verklaarde deze, dat hij door zijn uitvoerverbod de Balinezen poogde te duperen - met Bantam was men intussen goede maatjes geworden - aangezien de Bataviase Chinezen er schepen vol rijst heen brachten. Weer herhaalde hij zijn voorwaarde, dat al zijn rijst ter beschikking der Compagnie stond, mits aan boord van ieder vaartuig zich één of twee Nederlanders bevonden. Over Krawang had hij de goedgezinde tg. Pați aangesteld, wat hoop gaf. Het viel echter op, dat bij het aannemen en voorlezen van het schrijven der Hoge Regering geen de minste eerbied meer was betoond, een punt van gewicht bij de Javanen. Op 12 juli 1653 viel de afscheidsaudiëntie. Ook nu moest de Nederlandse gezant weer de havens langs, om zijn schepen met hout en rijst te vullen. Het resultaat was teleurstellend. Vrijhandel was zelfs niet beloofd, laat staan vergund.

Het 5e gezantschap van Van Goens. 1654.

Het was dus wel onder zeer ongunstige omstandigheden, dat Van Goens, juist teruggekeerd van zijn tocht tegen de Portugezen in VoorIndië, voor de vijfde en laatste maal de reis naar de hofstad in het begin van 1654 ondernam. Ditmaal begeleidden hem de koopman Gysbert van der Maen en de onderkoopman Wilhem Maetsuycker. Zijn taak werd verzwaard door de instructie, die hem opdroeg de Vorst er toe te bewegen, zijn wapens mèt die der Compagnie tegen de Makassaren te keren. Met dezen verkeerde de Compagnie sedert eind 1653 op voet van oorlog. Enige Javanen, uit Japara gekomen, hadden in Batavia beweerd, dat de Sunan wel bereid was tegen de Makassaren te strijden (Res. juli 1654). Daarbij diende hij er mee rekening te houden, dat de Hoge Regering slechts een afzonderlijk optredende krijgsmacht der Matarammers welkom was, dus geen hulptroepen aan boord van Compagnie's schepen. Ook mocht de Matarammer niet weten, dat de Compagnie zijn hulp bijzonder nodig had en diende de schijn gewekt te worden, alsof het verzoek om medewerking slechts uit Van Goens' koker kwam. Daarbij kwam nog, dat juist tóen Van Goens de 
diensten van de bekwame tolk Matthijs Pietersen miste en slechts kon beschikken over de hulp van de niet geheel betrouwbare kj. AnggaPradja en van de doodverlegen kapitein Melaju, entjik Bagus.

Tijdens deze ambassade kwamen de volgende zaken aan de orde.

Vooreerst ergerde de Sunan zich over het ontbreken van geschut, dat hem bij vorige gezantschappen wel was aangeboden. Dan sprak men over de belemmeringen bij de rijstuitvoer. Ten slotte kwam de hulp aan de Makassaren ter tafel. Terwijl de eerste twee kwesties geschikt werden, gaf de laatste vele moeilijkheden. Met de grootste inspanning gelukte het de gezant de Sunan tot een toezegging van hulp tegen Makassar over te halen, bestaande uit hulptroepen aan boord van Compagnie's zeemacht. Daar Van Goens niet gemachtigd was hulp in déze vorm te aanvaarden, ging hij er ijlings toe over zijn lastgevers te verzoeken zijn instructie te wijzigen. Eer het afwijzend antwoord uit Batavia (dd. 9 sept. 1654) hem bereikt had, was Van Goens reeds gebleken hoe ijdel 's Vorsten toezeggingen waren. Niet openlijk durvende te weigeren, hield de Sunan na het steekspel, terwijl de deelnemers nog te paard zaten, met zijn groten een bespreking op zaterdag 12 aug. 1654 . Hiervan konden de Nederlanders, zij het van verre, getuigen zijn, hetgeen blijkbaar bedoeld werd. 's Avonds werd hun, als het ware in het geheim, de uitslag dezer wonderlijke raadsvergadering medegedeeld, n.l. dat de Mataramse groten bijzonder weinig voor een oorlog tegen geloofsgenoten in Celebes voelden. Ofschoon de Vorst voor de vorm zijn vroeger aanbod handhaafde, voelde Van Goens toch wel, dat hij voor een verloren zaak streed en tijdens het derde gehoor hield hij, door voor des Sunans aanbod beleefd te bedanken, de eer aan zich.

Eind september 1654 weer in Japara teruggekeerd, hield hij zich daar minder met het afladen der Nederlandse schepen, als wel met het overvallen van twee ter rede liggende Makassaarse prauwen bezig. Hoewel deze geslaagde operatie met hulp der plaatselijke Javaanse overheid tot stand kwam, moet zij toch op de Vorst een allerpijnlijkste indruk gemaakt hebben. Stellig is daardoor de weg voor het volgende gezantschap, dat van Winrick Kieft, niet gebaand.

Van Goens repatrieerde op 28 jan. 1655 als kommandeur der retourvloot, die op 4 sept. van dat jaar de ankers in het Vlie liet vallen. Reeds vier dagen daarna diende Van Goens bij de Gecommitteerde Bewindhebbers uit het College van Heren XVII een „Vertooch” in, „wegens den presenten staet van de Generaele Nederlandsche Geoctroyeerde Oost-Indischen Compagnie" (Bijdr. K.I. IV 1856 p. 141-80). Mogelijk is, dat genoemde heren hem toen uitgenodigd hebben een 
deel van dit omvangrijke geschrift breder uit te werken, hetgeen hij deed onder de titel van "Corte Beschrijvinge van 't Eijland Java", dat 25 mrt. 1656 gedateerd is (Bijdr. K.I. IV 1856 p. 351-67). Deed dit gerecht zijn superieuren naar meer smaken, zodat hij op hun verzoek daarna een aanvulling gaf, getiteld: „Reijsbeschrijving van den weg uijt Samarangh, nae de konincklijke hoofdplaets Mataram" (Bijdr. K.I. IV 1856 p. 307-50)? Alleen het laatste geschrift zag tien jaar later anoniem het licht onder de titel van: „Javaensche Reijse gedaen van Batavia over Samarangh na de konincklijke hoofdplaets Mataram", en werd een vaak benutte bron voor onze kennis der Javaanse maatschappij in de $17 \mathrm{e}$ eeuw. 
IX.

\section{HET EERSTE CONFLICT.}

Besluit tot een gezantschap. 1655.

In 1655 verwachtte de Hoge Regering weer een Javaans tegengezantschap in Batavia, doch dit bleef uit, „daer wij hem geen rechter in connen stellen" (H.R. 23 juni 1655 K.A. 782 p. 298), ofschoon bij Van Goens' vertrek de Javaanse gezanten al benoemd zouden zijn (d. J. VI, 59).

$\mathrm{Nu}$ bleek achteraf, dat Van Goens in 1654 aan „de Mayt. formeel belofte gedaen" had, dat „S.H. van ons met een Persiaens paert ende goude thoom stont beschonken te worden", hetgeen ,gem. Commissaris ... versuymt" had in Batavia te rapporteren. Hieruit bleek opnieuw, hoezeer Van Goens zich had ingespannen om des Sunans gunst te winnen, zó zeer, dat hij naderhand vergat hierover zijn superieuren in te lichten (H.R. 8 sept. 1655 K.A. 782 f 616).

In afwachting van dit beloofde geschenk zond de Vorst met opzet geen ,ambassaetschap”, terwijl integendeel de Hoge Regering, ter voldoening van Van Goens' toezegging, besloot hem paard en toom te schenken.

Intussen waren de Mataramse havens enige maanden vóór 24 dec. 1655 gesloten, zonder dat daarvoor een reden kon bedacht worden. De Hoge Regering dacht aan haar vredesonderhandelingen met Bantam, waarvoor 's Vorsten toestemming niet gevraagd was.

Van Javaanse zijde werd echter te kennen gegeven, dat volgens het accoord van 1646 weer een delegatie verwacht werd, ,hetwelck”, zo meende de Hoge Regering, ,al vry veel is overgegeven, ende met verloop van tyt wel voor een specie van homagie ofte tribuyt soude connen worden genomen".

Toch overwoog men in Rade, dat het zeer slecht zou uitkomen, als men met deze Vorst in verwijdering geraakte, eer het geschil met Makassar vereffend was. Het werd daarom wenselijk geacht een gezant te sturen, hoewel niet meer met zulk een rijke schenkagie als 
voorheen. Eerst werd daartoe aangewezen de eerste koopman des Kasteels Hendrick van Zeelst, doch na op 2 oct. 1655 vertrokken te zijn, kwam hij voor Samarang plotseling te overlijden. Dientengevolge werd hij vervangen door het lid van de Raad van Justitie de koopman Winrick Kieft. Onderwijl had de havensluiting gewelddadige vormen aangenomen.

Toen de gezant Winrick Kieft op 31 oct. 1655 te Samarang aankwam, vond hij, langs de kust varende, de havens gesloten; die van Samarang was zelfs door drie bomen versperd (W. Kieft 395). De schepen der Bataviase burgers konden geen lading meer krijgen. Dagelijks kwamen de eigenaars, meest kleine luiden, bij Kieft hun beklag doen. Van de een werd n.l. het vaartuig op het land gehaald, dat van een ander verbrand; een derde of vierde werd in zee gejaagd. Hun bezit werd afgenomen; „tabee wensende met stockslagen”, joeg men de beroofden weg, zonder dat ze eetwaren mochten meenemen. Bij de strandheren kregen ze nul op het rekest. Sommige vaartuigen werden zelfs in stukken geslagen (d. J. VI, 61).

Ook na Kieft's aankomst op 21 nov. 1655 in de hofstad hielden de klachten aan. De tugurs, dienaren der opperstrandheren, waren naar de kust gezonden, om alle kleine vaartuigen te verbranden en de grote voor de oorlog uit te rusten (W. Kieft 396). Uit Samarang komende Maleiers berichtten zelfs, dat de tugurs alle vaartuigen van ,swarten, Chineesen, Maleiers hebben uijtgejaecht, sonder in 't minste iets mee te voeren". Bij weigering werden ze alle verbrand (W. Kieft 397). Toen Kieft ten slotte op 7 dec. 1655 aan boord stapte, werden al zijn goederen „door en door bij 50 toegoers gevisiteert" (W. Kieft 398).

Dat dit sluiten der havens zwaar op de kustbewoners drukte zelfs de vissers mochten niet uitvaren en slaven geen stuk hout in het bos hakken - deerde de Vorst weinig, die zou gezegd hebben: „In 't minste van sijn voorneemen niet te desisteeren, al souden sijn onderdanen niet als sout en rijs eeten".

De Hoge Regering heeft zich over deze gewelddaden tegen burgers en Chinezen herhaaldelijk bitter bij de Javaanse autoriteiten beklaagd. $Z$ ij verzwaarden de taak van haar gezant, Winrick Kieft, in sterke mate.

\section{Het gezantschap van Kieft. 1655.}

Het gezantschap, dat onder deze ongunstige omstandigheden naar Mataram trok, ging dus niet vrijwillig. Door het handelsverbod oefende de Sunan druk uit. Ten gevolge van het plotseling overlijden van 
Hendrick van Zeelst vertrok Kieft pas op 2 oct. 1655. Het gevolg was, dat het gezantschap ver over tijd in de hofstad aankwam. Daarbij kwam nog, dat het geschenk kleiner was dan dat van het vorige jaar. Bovendien was de gezant, ofschoon lid van de rechterlijke macht, niet voor zijn taak berekend: opgeblazen, karakterloos, laf. Zijn toelating had reeds heel wat voeten in de aarde. Twee en een halve week na zijn aankomst in Samarang mocht hij pas in gezelschap van de vier opperstrandheren opreizen (W. Kieft 393). Zijn komst onderbrak de gewelddadigheden tegen de burgerhandelaars niet. De Vorst verkeerde in een slechte stemming. Behalve dat een Kratonverbouwing hem bezig hield, was hij uit zijn humeur over een vermeend gezantschap van de Balische koning naar Batavia, de vredessluiting der Compagnie met Bantam, en bovendien over de plichtsverzaking van enigen zijner groten, ,omdat niet vaerdigh aen sijn werck en hadden gearbeijt; (hij) had se laten binden en op de paszeeban laten setten in de son te braden" (W. Kieft 396).

Tot een gehoor werd Kieft niet toegelaten; de geschenken moesten aan ondergeschikten worden overgegeven, „bij hooge protestatie... soo verre ons benart siende van dese wreede tijgers" (W. Kieft 397). Bij het afscheid der strandheren protesteerde hij nogmaals, maar vergeefs: „'t was de Moor geseept”. Op 2 december werd deze gezant, zoals de Hoge Regering het uitdrukte, ,genoegsaem met ignominie weder afgesonden" (d. J. VI, 60). Onderwijl viel van een wijziging in het rijstuitvoerverbod niets te bespeuren.

\section{Reden der gewelddadige havensluiting.}

Wat kan de oorzaak der kwade behandeling juist van particuliere vaartuigen geweest zijn? Waarom werd de gezant der Hoge Regering zo smadelijk afgewezen? Om welke reden werden ten slotte de havens voor anderhalf jaar gesloten?

Wat het eerste betreft, waarschijnlijk laten deze gewelddaden zich het gemakkelijkst verklaren door aan te nemen, dat tugurs, belast met het handhaven van 's Vorsten handelsmonopolie langs de Javaanse kust, de burgerhandelaars als ergste overtreders van des Sunans bevelen beschouwden. Immers, slechts handelsschepen, voorzien van een vertegenwoordiger der Hoge Regering mochten op de Javaanse havens handel drijven, was herhaaldelijk vastgesteld en verzekerd. Blijkbaar was dit gebod reeds jaren lang stilzwijgend en wellicht met goedvinden der strandheren overtreden. Thans wenste de Vorst zijn voorschriften 
stipt geëerbiedigd te zien en zijn toorn uitte zich in molestaties van schip en bemanning.

Winrich Kieft, niet de rechte man op de goede plaats, was dus een slecht advocaat voor een kwade zaak. Dit kan zijn gering succes afdoende verklaren.

Bovendien mag men zich afvragen, of ook geen buitenlandse invloeden de Sunan tot een straffere houding tegenover de Nederlanders bewogen hebben. Men denkt daarbij onwillekeurig in de eerste plaats aan de Islam, in de Mataram en omliggende landen beleden.

\section{De Pan-Islamietische agitatie.}

Gelijk wij zagen, stond de Sunan sedert 1652, het jaar waarin hij aan zijn monopolistische plannen een begin van uitvoering gaf, met Bantam op redelijk goede voet. Dit blijkt onder meer uit het voornemen ener huwelijksverbintenis tussen beide vorstenhuizen.

Het lijkt ook geen toeval, dat juist wanneer 's Vorsten ongenoegen zich uit in een havensluiting, Bantam de strijd met Batavia hervat.

Er blijkt dan ook in Mataram een pro-Bantamse partij te bestaan, die de ondergang der Compagnie gaarne zou zien en gemakkelijk het gerucht gelooft, „dat de Bantammers Batavia meest onder de voet, de buytenwercken al in, en den Mataramschen coninck het daerin wesende volck en goet aengeboden hadden, mits assistentie van crijchslieden en canon, sijnde maer één fort (nog) te winnen" (D. 7 dec. $1656 \mathrm{p}$. $30-31)$.

Tegen deze doorzichtige poging, om Mataram in de oorlog te betrekken, had Compagnies vriend tg. Pati „seer gestreden”, daar hij Batavia uit eigen aanschouwing kende en wist, hoeveel sterker die stad was dan vroeger. In het bijzonder had hij met ng. Wangsa-Radja, gouverneur van Samarang, „dapper overhoop gelegen”, en niet zonder succes. Doch eer het zover was, had de Hoge Regering ernstig geklaagd over de boosheid harer „wedersytse nagebueren... die ons elck om 't seerst syn plagende" (Gen. Miss. dd. 24 dec. 1656 d. J. VI, 55). Zowel van haar Ooster- als van haar Westerbuurman had Batavia last, ook het volgende jaar, toen het heette: „de Sousouhounangh Mataram ons aen de ééne syde quellende mettet sluyten syner haevens ... hetwelck ... door die van Bantam noch wordt vermeerdert... met rooven, steelen ende moorden" (d. J. VI, 65). Ten slotte hadden de Bantammers de Compagnie „soo te water als te lande openbaeren oorlogh aengedaen”. Op 3 mei 1656 hadden de Nederlanders het reeds geraden gevonden, 
om hun loge in Bantam heimelijk te ontruimen; in de nacht van 8 op 9 juli sloeg de vlam uit de rietvelden en suikermolens van Angké (d. J. VI, 66). Daarmede was de strijd met Bantam weer begonnen.

$\mathrm{Bij}$ al deze moeilijkheden voegden zich nog die met de Makassaren. Van eind 1653 tot begin 1656 is de Compagnie in oorlog met de vorst van Makassar geweest. Wij zagen reeds, hoe zij in 1654 vergeefs gepoogd heeft, de Sunan tegen deze in het geweer te brengen. Daarentegen is het waarschijnlijk, dat het Makassaarse voorbeeld de Matarammer tot zijn anti-Nederlandse houding aangespoord heeft.

Van deze drievoudige verstandhouding - een verbond is het kwalijk te noemen - was men zich in Batavia wel bewust. Gysbert van Hoecq, die op 28 juli 1655 te Batavia aankwam, geeft daarvan de volgende, verwarde schets: ,twee van de machtigste coningen van ... Java waren aangekomen den Coninck van Bantam ophitsende, om ... geen vorder Pays met ons te maken, maer openbare oorloch aenzeggen". De pogingen der Hoge Regering ter verlenging van het dat jaar aflopende tienjarige bestand, welke aanvankelijk succes boekten, dienden door hen gedwarsboomd te worden (H.R. naar Japara dd. 20 aug. 1655 K.A. 782 p. 548). Inderdaad gelukte het Mataram en zijn handlanger Tjerebon - mogelijk worden deze beiden met die twee machtigste koningen bedoeld - tussen Batavia en Bantam twist te zaaien. Doch ook de Makassaar was van de partij, daar ,den Coninck van Maccassaer... geen kleyne hulpe aenbiedt". Een algemene opwinding bezielt de massa „synde dese Machometanen altemael so iverigh ... om sekere prophetie, haer onlanghs door den verleyder Machomet... gepropheteert, te kennen gevende, dat indien sy tesamen eendrachtigh den oorlogh tegen de Christenen aenvingen, hij haer victorie en overwinninge verzekerde". Het geestelijke element laat zich dus niet onbetuigd, daar „een van haer (Javaanse?) Papen of Priesters op Bantam geweest was ende nu oock na Macassar vertrocken" (S.P. l'Honoré Naber, De derde Voyagie van G. Hoecq naer O.I. Marineblad XXV, 193, 289, 422, 533).

Het valt ook op, dat de langdurige havensluiting eveneens door een „paep veroorzaeckt" heette (D. 7 dec. 16556). Deze had de Sunan „een schoon en raer cleedt vereert... seggende, het op Samarangh geruilt te hebben". De Vorst was hierover boos geworden, daar hij van zijn strandheren zulke fraaie kleden niet kreeg. Het gevolg was, dat hij ,niet alleen tot voorschreven resolutie quam, maer oock haer al te samen strengelijck strafte". De kern van dit wonderlijke verhaal kan wezen, dat een panislamietische groep langs rechte en kromme wegen de Sunan trachtte te bewegen, tegen de Nederlanders op te treden. Men 
rekene er evenwel mede, dat dit verhaal de berichtgever onder de invloed van Spaanse wijn ontlokt was. Overigens moet het juist zijn, dat de strandheren weinig voor havensluitingen, die hun inkomsten besnoeiden, zullen gevoeld hebben. Doch fanatici stappen gemakkelijk over zulke economische bezwaren heben. Niet toevallig merkt de Hoge Regering in een brief aan haar resident te Japara juist in deze dagen op, dat de Bantammers, evenals de Makassaren met de Matarammers van één religie waren (Bat. 23 juni 1655 K.A. 782 p. 298). 1

Een betrouwbaar getuige is voorts de kommandeur Johan Truytman, die over zijn reis naar Java's Oostkust in april 1657 rapport uitbracht (K.A. 1110 f. 785 en vlg.). Hierin stelde hij de mogelijkheid, dat vroeger door de Javanen aan Bantam om hulp was gevraagd, of wel dat er enige verstandhouding had bestaan, zoals eertijds ook te Makassar geschied was.

\section{Maatregelen tegen de havensluiting. 1656.}

Omtrent hetgeen de Hoge Regering tegen de sluiting der Mataramse havens ondernam, zijn wij door het ontbreken van bronnen niet zo best ingelicht.

Zo besloot zij op 10 febr. 1656 de vroegere resident in Japara, D. Schouten, als ambassadeur naar Mataram te zenden (Res.) „om alle nieuw geresen questien en verschillen... weder met vrientschap te beslechten". Dit is blijkbaar bij een poging gebleven. Daarentegen trachtte zij door vlootbewegingen in het Mataramse land schrik te verspreiden.

Daarom zond zij op $28 \mathrm{mrt} .1656$ naar Java's slecht bekende zuidkust een galjoot, dat onder schijn van kartering der kustlijn onrust moest wekken in het Mataramse. Aan deze tocht hebben wij wellicht het vrij behoorlijk op kaart brengen der zuidkust te danken.

Zelfs kort voor de ontsluiting der havens, op 11 oct. 1656 zond de Hoge Regering nog een drietal schepen naar het oosten van het eiland, om op „des Mattarams gedoente te letten”, doch ook om er schrik te verspreiden. De zakien langs Java's noordkust leken n.l. „vrij scrabreuser als voorhenen". De nog steeds in de loge vertoevende residenten zaten er als ,geconfineert”; de bemanning van het op 22 sept. 1656 uit Batavia vertrokken jacht de ,Schol", had niet aan land mogen gaan.

1 Een duidelijke aanwijzing voor Mataramse sympathieën met de Bantammers is de dezen verleende toestemming om in des Sunans rijk oorlogsvaartuigen te kopen, zelfs nog voordat de havens voor de Nederlanders gesloten werden (H.R. aan Volsch dd. 18 apr. 1655 p. 154). 
Intussen bleef een zeker diplomatiek verkeer niettegenstaande de havensluiting doorgaan. Zo ontving de Hoge Regering brieven van de tumenggungs van Pati en Demak tegelijk met twee op Oedjong Bajang verongelukte Nederlanders. Eerstgenoemde schreef over het in 1653 te Batavia aangekochte geschut. Drie al te zware stukken wilde hij tegen evenveel lichtere inruilen, die voor gorabs bestemd waren. De Demakker verzocht om ijzer en musketten. Waren deze verzoeken van hogerhand ingegeven? In ieder geval liet de vorm, zo belangrijk bij de Javanen, te wensen over: open brieven, gebracht door kleine lieden. De gegriefde Hoge Regering liet deze verzoeken door haar OntvangerGeneraal afwijzend beantwoorden en beklaagde zich ernstig over het in 1655 geleden yeweld (Res. 24 mrt. 1656).

Maar ook de Mataram zat niet stil.

De sluiting der havens ging gepaard met een krachtige uitrusting van schepen, zonder dat de bedoeling duidelijk bleek. Sedert het vertrek van Kieft heerste er een „ongestadig gewoel van de Vorst en desselfs subalterne regenten" (H.R. 27 mrt. 1656 K.A. 783 p. 136). Er werden steeds maar schepen uitgerust (H.R. 15 mei 1656 K.A. 783 p. 184). Ook de zeilen, riemen en masten waren reeds gereed gemaakt (H.R. 23 juni 1656 K.A. 783 p. 241). Er zouden 400 vaartuigen te water zijn gelaten, waaronder zeer grote (Res. 11 oct. 1656). Zelfs toen het openen der havens ter sprake kwam, werd nòg gehoord over een plan om niet minder dan 40.000 kielen in zee te brengen, van elke „negrie” tien! (D. 7 dec. 1656 p. 31 ).

De Hoge Regering raakte daardoor eveneens in oorlogsstemming en sprak al over het roven van rijst en het verbranden van jonken. Maar toen de Sunan niet tot een besluit scheen te komen, meende men in Batavia, dat al zijn plannen wel eens plotseling in rook zouden kunnen verdwijnen (H.R. 21 sept. 1656 K.A. 783 p. 385). Deze prognose bleek juist. 
$\mathbf{X}$.

\title{
HET STELSEL DER VIER VOORNAME STRANDHEREN.
}

\author{
De opening der havens. 1657.
}

Nadat reeds lang allerlei geruchten en berichten Batavia hadden bereikt omtrent het spoedig heropenen der Mataramse havens, kreeg men hieromtrent pas meer zekerheid door de verschijning in rade van Indië van de Japarase resident, Evert Michielsen op 6 mrt. 1657 (D.). Hij rapporteerde toen mondeling en schriftelijk, dat "d' selve wel niet in 't geheel geopent waren, maer dat dagelicx stonden g'opent ... te werden". Het oponthoud werd aan de ,jalousie der strantheeren" waarover hierna meer - toegeschreven.

Ten einde schepen af te laden en berichten in te winnen, daar men ,sedert veele maenden niet dan seer variabele ende dickmaels geckelijcke tijdingen" bekomen had, werd behalve de terugkerende resident, ook de opperkoopman Joan Truijtman naar Japara gezonden (D. 6 mrt. 1657).

Inderdaad waren bij diens verschijnen alle zeehavens op last van de Sunan weer opengesteld, terwijl 7ijn persoon ,statelijck ende met vrundelycke reverentie" ontvangen werd, vooral door tg. Patii, die hij in zijn residentie was gaan bezoeken (K.A. 1110 f 785; D. 17 apr. 1657).

Ter ontsluiting der havens had de Sunan overal boden heen gezonden, naar Japara, Demak, Samarang, ja tot Tjerebon toe. De Chinese en andere handelaars, die 19 maanden waren aangehouden, keerden eindelijk met volgeladen schepen naar Batavia terug.

\section{De bestuurshervorming.}

Als reden voor de havensluiting werd door de Javanen een bestuurshervorming opgegeven. Winrick Kieft deelt dit op zijn wijze mede: „Ede. Heeren, hier moeten wij ons weer met een sottebols-praetje laten patijen, dat voor dees tijt niemandt ... coopmanschappen soude mogen uijtvoeren, alsoo de Conincklijcke Maijt. besigh was nieuwe wetten 
te setten, heel anders als sijn vader gebruijckt hadde". Het contract met de Compagnie zou echter gehandhaafd blijven (W. Kieft 397; vgl. Gen. Miss. 16 dec. 1660 in d. J. VI, 87).

Kieft kon dit niet met wat hij opmerkte, verenigen, doch moest geduld hebben, tot Z.M.'s ,resolutie daerinne voltrocken was".

Ons is evenmin duidelijk, wat tijdens de havensluiting in het Mataramse staatsbestuur gewijzigd is, of het moest een nòg straffere bestuursvoering zijn dan voorheen, een nòg volstrekter onderwerping der kusten aan de twee opperstrandheren.

$\mathrm{Na}$ afloop der havensluiting merkten wij daarentegen wèl een verandering van het staatsbestuur op. Deze bleek vooreerst uit een wijziging in de verhouding van de Vorst tot de Compagnie.

De trotse Matarammer wenste geen bezendingen uit Batavia ten zijnent te ontvangen. Als de Gouverneur-Generaal iets begeerde, hadden de vier voornaamste strandheren daarover te beraden (D. 26 juni 1657). De Hoge Regering voelde zich daardoor niet beledigd, doch achtte het „voor d'E. Compagnie een treffelycke saecke". De stranden waren onder hen gesteld, en wel aan ,haer vieren t'saemen” (D. 7 dec. 1656 p. 33). Zij dienden solidair te wezen, Geen hunner betekende meer dan de ander, verzekerde ng. Marta-Nata, hetgeen hij tot „drie male toe met hoogen eedt becrachtighde des Conincx woort te wesen dat sij... souden één ende haeren uijtvoer eguael te wesen, begerende hij van d'een niet een cleedt meer dan van d'ander". Het is een soort van decentralisatie, waarbij de stranden een beperkte autonomie verkregen.

Echter, hoewel gelijkwaardig, was hun taak toch niet gelijksoortig; hun werk was n.l. op de volgende wijze verdeeld: tg. Pați was verantwoordelijk voor Batavia; ng. Marta-Nata van Japara voor Djambi; tg. Sura-Nata van Demak voor Palembang, en ng. Wangsa-Radja van Samarang voor Suka-Dana op Borneo, ,opdat se terecht geraken" (D. 7 dec. 1656 p. $31 ; 27$ juni 1657 p. 197).

Mogelijk was dit systeem ten minste ten dele reeds eerder in zwang. Blijkens schrijven der Hoge Regering dd. $27 \mathrm{mrt} .1656$ was toen reeds bekend, dat tg. Pați over de zaken van Batavia gesteld was. Dat Demak met Palembang te maken had is begrijpelijk, gezien de in de Babad vastgelegde oude traditie. Ook had tg. Pați sedert 1648 sterke persoonlijke relaties met de Nederlanders. De andere verhoudingen zijn minder sprekend.

Zeker gold dit stelsel nog tot 1659 , toen Djambische gezanten door de Japaarse gouverneur en de Palembanger door de Demakse met verschillende geschenken bedacht werden (D. 13 nov. 1659 p. 227). Het 
moest vanzelf ophouden, toen enkele dier vazallen hun trouw aan de Sunan opzegden.

Terwijl de strandheren groter bevoegdheid verwierven, verdwenen de ambtenaren, die tot dusver hun macht door toezicht verkort hadden, de tugurs, de uitgezondenen der opperstrandheren Wira en Wira-Djaja. Men zal hen bij het beëindigen van het stelsel der vier opperstrandheren opnieuw op de voorgrond zien treden, zij het tijdelijk.

Doch behalve over hun gebied in engere zin hadden de vier opperstrandheren nog zeggenschap over andere delen der kust. $\mathrm{Kj}$. ng. WangsaRadja van Samarang beschikte ook over Sidaju (D. 4 sept. 1657 p. 255-57; D. 12 mei 1659 p. 95). Tg. Pați heeft tevens macht over Indramaju en het gebied tot aan de Tji Tarum; hij stelt er zijn broeder Tjitra-Nala over aan (H. v. Gent dd. 20 juli 1653 T.B.G. LXIII 1923 p. 536; v. Goens 130). Later, wanneer tg. Pați aan het hoofd van SuraBaja gesteld is, blijkt hij eveneens over Pasuruhan te heersen. Evenzo heeft kj. ng. Marta-Nata behalve over Japara, ook nog over Batang te zeggen. Mogelijk was op deze wijze de ganse Noordkust van Java onder de vier strandheren verdeeld.

Hoe hield de Vorst, nadat de tugurs hun werk gestaakt hadden, toezicht op de vier grote strandheren? Waarschijnlijk diende hiertoe het voorschrift, dat steeds één hunner ten hove zou vertoeven, om daar elke twee maanden afgelost te worden (D. 7 dec. 1657 p. 31). Of dit regelmatig geschied is, mag betwijfeld worden, daar bepaalde strandheren soms veel langer boven bleven.

Deze vier hoge ambtenaren zijn vergelijkbaar met dergelijke viertallen in oudere tijdperken van Java's geschiedenis. Men denke aan de vier ambtenaren, die na Gadjah Mada's dood deze enige rijksbestuurder moesten vervangen. Of de vier, die op het einde van sultan Agung's regering gezamenlijk het ambt van tumenggung Mataram waarnamen. Of de vier secrete raden van sultan Agung, die over de 500 voorname orang kaja's stonden.

Rouffaer onderstelt, dat de Sunan in 1655 behalve deze 4 Wadana's Pasisiran ook 4 Wadana's djaba of „Buitenregenten” over de Nagaragung (d.i. het grootste deel van Sura-Karta, Jogja-Karta, Keḍu en Bagelen) naar analogie heeft aangesteld; vrij zeker waren deze ambtenaren er tenminste in 1682 (G. P. Rouffaer, Vorstenlanden 52).

\section{De twee groepen strandheren.}

Behoudens de reeds vermelde uitzondering, werkten de vier strandheren zelden samen. Integendeel, spoedig kan men bij hen een twee- 
deling onderscheiden. Er tekent zich een nauwe verbintenis af tussen tg. Pați en zijn zwager, tg. Sura-Nata van Demak (D. 7 dec. 1661, p. 31; D. 16 oct. 166). Zij zouden ,als één" zijn en tg. Pați beraamde zelfs al het graven van een vaart tussen Djuwana en Demak. Trouwens, reeds vanouds stonden beiden met elkander op goede voet (v. Goens 249), zodat v. Goens deze tg. Sura-Nata ,mede onsen seer goeden vrund" noemde.

Anderzijds heetten ng. Marta-Nata van Japara en ng. Wangsa-Radja van Samarang ,eensgesint” (D. 3 mrt. 1657 p. 112). Zij werkten samen tegen tg. Pați, die ze er van betichtten (tegen des Sunans bevel?) de uitvoer van rijst en grabat (allerlei koopwaar?) naar Batavia te hebben toegestaan, niet alleen aan Europese burgers, maar zelfs aan Chinezen en Maleiers (D. $3 \mathrm{mrt} .1657$ p. 111). Omgekeerd noemde tg. Pați zijn ambtgenoot in Japara weinig kredietwaardig (D. 7 dec. 1657 p. 32); tussen beiden heerste ,jalousie ende ongunst". Met de Samaranger lag tg. Pați „dapper overhoop” (D. 7 dec. 1657 p. 31). Over de uitplundering der Nederlanders in 1655 hadden beiden harde woorden gehad.

Daarom trad sterker dan de samenwerking het persoonlijk streven der strandheren naar voren. De gebrekkige regeling bevorderde dit. Immers, enerzijds moesten zij eensgezind en eendrachtig optreden, anderzijds kreeg ieder een eigen taak aangewezen. Men vrage echter niet, op welke wijze.

Tg. Paṭi diende zich uitsluitend met Batavia te bemoeien, maar de Nederlandse factorij lag juist in het gebied van zijn tegenstander, de gouverneur van Japara. Vandaar dat hij al dadelijk een verhuizing der loge naar Djuwana bepleitte (D. 27 juni 1657 p. 196-97). Naar hij vertrouwde, zou de bestaande regeling veel moeite geven; „het soude dan goed sijn; dat mijn broeder een logie maeckte op Jouana, want dat staat onder mijn alleen", zei hij.

Bovendien overwege men, dat de Nederlanders de beste klanten der strandheren waren; de Chinezen, die overal zaten, wellicht uitgezonderd. Hij, die hen binnen zijn gebied had, was dus bevoorrecht boven de andere. Geen wonder dus, dat tg. Pați weinig over de nieuwe regeling te spreken was. Bezien wij thans de persoon van deze vriend der Compagnie wat nader.

Tg. Pati en zijn mededinger, ng. Marta-Nata.

Tg. Pați verschijnt het eerst ten tonele tijdens het gezantschap van 1648 onder de naam van kj. Suta; hij wordt dan in één adem met zijn 
broeder kj. Angga-Pradja genoemd. Destijds had hij met het bestuur van Samarang te maken. Mèt zijn broeder, die wij tot 1667 als tolk en in 1673 nog als secretaris zien optreden (Jap. 21 sept. 1673 K.A. 1185), zorgde hij voor de ontvangst van Nederlanders en er kwam geen gezantschap uit Batavia, of hij was het behulpzaam. Zo leidden de gebroeders in 1648 de Nederlandse gezanten door de oude en nieuwe Kraton rond.

Het volgende jaar werd $\mathrm{kj}$. Suta tot tg. Nata-Airnawa van Pați verheven en sedert staat hij meest bekend als tg. Pați. Zijn verhouding tot de Compagnie was in den regel goed.

Zo meende de Hoge Regering in 1651 van hem de „meeste assistentie” te kunnen verwachten, zodat zij hem ter aanmoediging stilletjes met een „,keldertje gedistilleerde wateren” bedacht (H.R. dd. 9 oct. 1651 T.B.G. LIX p. 462). Dit smaakte naar meer, zodat hij er later zelfs om verzocht (D. 10 dec. 1659). In een moeilijke situatie boezemde zijn aanwezigheid vertrouwen in (v. Goens 119).

In 1653 bracht hij aan het hoofd van het enigste Javaanse gezantschap een bezoek aan Batavia. Hij schreed mee achter de baar van de pas overleden G.G. Reyniersz. Dit bezoek blijkt later een diepe indruk te hebben achter gelaten.

Het volgende jaar voerde hij niet alleen gezag over Pați, doch ook over Indra-Maju, tot aan de rivier van Krawang, de tji Tarum (v. Goens 130).

Tijdens Van Goens' je gezantschap in 1654 nam hij deel aan de besprekingen over mogelijke Mataramse hulp aan de Compagnie tegen Makassar. Behendig spaarde hij toen kool en geit (v. Goens 156). Dit belette hem niet Van Goens van dienst te zijn bij een overval op ter rede van Japara liggende Makassaarse prauwen. Dit was zijn laatste ontmoeting met onze gezant, die hem in Nederland „onse beste vrund" zou noemen (v. Goens 249), zelfs ,den besten, die ick oijt gefrequenteert heb... daer ick veel ongeveynstheyt ende tegen haer nature eenige trouwe in bevonden hebbe" (v. Goens 263). Hij wist ook met Nederlanders ,habil ... te verkeeren” (T.B.G. LXII p. 536).

Tijdens de eerste havensluiting (1655-57) zal hij wel niet te krachtig voor zijn Hollandse sympathieën zijn uitgekomen, schijnt zelfs enigszins op de achtergrond te zijn geraakt, „,buyten zijn dienst gesteld” heet het (H.R. 5 mrt. 1655 K.A. 782 p. 8). Maar zodra de anti-Nederlandse stemming luwde, bestreed hij de groep, die Mataram aan Bantam's zijde wilde brengen (D. 7 dec. 1656 p. 31). Door zijn toedoen, zo beweerde hij, zouden zelfs de havens weer ontsloten zijn, waarna de Vorst „d'openinge der havenen aan Patti gedefereert" had. Korte tijd achtte 
hij zich de onmisbare schakel tussen Batavia en de Kraton. Op vorstelijk bevel moesten de Nederlanders op zijn kosten een loge te Djuwana, Pați's haven stichten. Compagnies schepen dienden, ook al hadden ze eerst Japara aangedaan, daarna ook Djuwana te bezoeken. In verband daarmee zou een nieuwe vaart van Demak naar Djuwana gegraven worden. „Plausibele dingen”, spotte de kundige resident Michielsen, wie tg. Paṭi dit alles toevertrouwde. Ook gaf hij hoog op van zijn macht ter kuste, „met seclusie van anderen”. Ook van elders wordt dit verzekerd (D. 26 febr. 1657 p. 104). Hij zou bevoegdheid over alle zeehavens gekregen hebben (D. 26 juni 1657 p. 196), terwijl hij later nogmaals verklaarde, dat de Sunan zich niet meer met de stranden wilde inlaten, „maer op hem tommagon Patti alleen laten aencomen” (D. 3 mrt. 1657).

De opperkoopman, Johan Truytman, die na de opening der havens naar Java's oostkust gezonden werd, over welke reis hij een rapport opstelde (K.A. 1110 f. 785), bracht deze grootspraak tot normaler afmetingen terug. Tg. Pați zou slechts de eerste in rang der vier strandheren zijn en hun gemeenschappelijke bijeenkomsten mogen voorzitten. Alleen als hij een bijzondere commissie van de Sunan kreeg, betekende hij wat meer. Het was echter een feit, dat hij daartoe vaker dan de anderen werd gebruikt. Overigens strekte zijn macht zich niet verder uit dan zijn eigen gebied (D. $3 \mathrm{mrt} .1657$ p. 112). Hiertoe behoorden behalve Pați nog Djuwana, Rembang en Padjangkungan.

Bij de Nederlanders poogde hij een wit voetje te krijgen door op zijn verdiensten te wijzen. Hij had de schipbreukelingen "Jan ter Woude en Jacob syn maet", die voor de Sunan gebracht waren, op diens bevel aan hun landgenoten teruggegeven. Ook vier schipbreukelingen, van Solor op Java's oostkust vervallen en naar Mataram gevoerd, had hij vóór hun tijd verlost (D. 26 juni 1657 p. 196). Later zou hij zulke diensten blijven bewijzen. ${ }^{1}$

1 Deze schipbreukelingen waren afkomstig van het schip uitgezonden om naar de op Australië's Westkust gestrande „Gulden Draak” uit te zien. Zij hadden zelf hun schip verloren en waren in een open sloep naar Java gevaren. Vier hunner wisten ergens aan de zuidkust van Oost-Java aan land te komen. Onder zware ontberingen trokken zij te voet westwaarts en hadden op 28 of 29 juni 1658 voor het eerst weer mensen gezien op een plaats, die zij Baijhim (Bajem?) noemden. Vandaar werden zij naar Kalambret (Kalangbret) gebracht, waar het plaatselijk hoofd hen met 15 tot 20 man gevolg ontving. Drie weken werden zij er aangehouden. Toen reisde deze ,orancay" (orang-kaja) naar Mataram. Een 15 tot 16 dagen was men onderweg. In de hofstad moest men een tweetal weken wachten: soms moesten zij naar de Kraton gaan, waar hun gevraagd werd, waar zij vandaan 
Niet slechts tot de Compagnie en haar dienaren beperkte zich zijn hulp, ook haar onderdanen konden op zijn bijstand rekenen. Zo had hij voor een Chinees gepleit, die zijn schip kwijt was; hij had het afladen van schepen der Bataviase burgers bevorderd. Hierdoor haalde hij zich de haat zijner ambtgenoten op de hals, maar, zo verzekerde hij aan de Gouverneur-Generaal, „het en sal geen swarigheijt hebben voor eenen broeder" (D. 3 mrt. 1657 p. 112). Natuurlijk vond ook Truijtman in Pați een goed onthaal en voortreffelijke huisvesting (D. 7 apr. 1657).

Inderdaad maakte hij op de heren in Batavia een uitstekende indruk. Zij hadden er geen bezwaar tegen, zich in plaats van tot de Sunan, tot de vier strandheren te moeten wenden, „ofte voornamentlyck tommagon Patij..., die daertoe gequalificeert" was, „dat voor d'E. Compagnie een treffelycke saecke sij" (D. 26 juni 1657 p. 194). Zij noemden hem een „sonderlingh genegen heer tot de Compagnie" (D. 3 sept. 1657 p. 252), die haar ,seer gunstigh in alles was” (D. 8 sept. 1657). Toen hij vanuit Mataram om ,allerhande dranck" verzocht, werd hij daarvan zo veel mogelijk voorzien (D. 10 dec. 1659).

Maar deze vriend der Nederlanders bezat een geduchte mededinger in de gouverneur van Japara, ng. Marta-Nata, over wie wij veel slechter zijn ingelicht. Waarschijnlijk is dit te verklaren uit het feit, dat hij zo laat aan de kust optrad.

Deze wordt pas vermeld in de uitgaande missive van $5 \mathrm{mrt} .1655$ (K.A. 782 p. 8). Hieruit blijkt de Hoge Regering vernomen te hebben, dat tg. Pați uit zijn dienst gesteld was, en ,daertoe de twee snoode ende doortrapte gasten Nabeij Martanata ende Wangsaradja gevordert waren". Men kende deze beide vrienden dus reeds. In Truijtman's rapport wordt de eerste, twee jaar later, geveinsd en arglistig genoemd, „de Compagnie gantsch niet toegedaen”. Omgekeerd was de waardering

kwamen. Tenslotte kwamen er 5 tot 6 man van het volk van tg. Pați, dic daar verbleef, welke de Nederlanders in zijn huis haalde. De volgende dag vertrokken zij reeds onder geleide van een zijner dienaren en gevolg naar Pați. Daar moesten zij wachten, tot de tumenggung zelf ook zou komen. Maar na een week verscheen de „Duytse Javaen... Michiel Zeeburgh”, die te Djuwana woonde, in Paţi en raadde hun aan naar het Japarase opperhoofd, Evert Michielsen te schrijven. Hij bracht hun zelfs papier en inkt en beloofde de brief te bezorgen, daar hij toch in Japara moest wezen. Nadat hij zes tot zeven dagen weg was geweest, verscheen hij weer en bracht voor ieder twee pakken kleren, schoon ondergoed en wat geld mee. Acht dagen later kwam er een assistent uit Japara, die na eindeloze onderhandelingen met de Javanen er in slaagde, de schipbreukelingen te mogen meenemen. Samen reisden zij toen over Djuwana naar Japara, waar zij op 23 sept. 1658 aankwamen (S. P. l'Honoré Naber, In een open sloep van Australië naar Java. Marineblad XXV 1910--11 p. 18 \& vlg.).

Verh. dl. 33 
evenmin groot. Over een ander bekwaam dienaar der Compagnie, Evert Michielsen, schreef ng. Marta-Nata, dat deze waarlijk niet deugde, „wij hebben geen behagen in hem" (D. 27 juni 1657 p. 199).

Laat ons thans zien, hoe de strandheren trachtten aan de wensen van hun Vorst te voldoen. Deze blijken n.l. van fiscale aard te zijn. Sunan Mangku-Rat I zal bij zijn onderdanen als gierig bekend blijven.

Financiële druk op het volk. 1656-59.

De decentralisatie in het Mataramse rijk betekende geen verlichting van lasten voor het volk, integendeel! Reeds dadelijk wordt gezegd, dat hij de beste man zou wezen, die het meeste opbracht (D. 7 dec. 1656 p. 31). Vooral op ijzer was Z.M. gesteld, waarvan hij krissen, pieken, musketten en vaartuigen wilde laten maken. Tg. Pați zou zelfs prauwen naar Batavia zenden, om zoveel mogelijk ijzer te verwerven. Doch spoedig luwde deze belangstelling weer (Rapport Truijtman K.A. 110 f $785 \mathrm{v}$ ), ofschoon die voor goud aanhield.

Japara's gouverneur, ng. Marta-Nata, stelde ,alle practijcken, jae gewelt te werck, om gelt bijeen te schrapen". Hij was ook het eerst aan bod om naar boven geroepen te worden ter geldelijke verantwoording. Daarom spaarde hij zomin zijn eigen volk als zijn vreemde onderzaten de Chinezen, zelfs niet de erfgenamen van overledenen. Zodoende hoorde men dagelijks ,niet dan van vangen, binden, afpersingen van gelt ende andere tijrannige actien" (D. 7 dec. 1656 p. 34).

Drie jaar later is er zelfs sprake van een hoofdgeld, na Garebeg Mulud (27 nov. 1659) op te brengen, n.l. 7/4 rijksdaalder voor de gewone man, $9 / 4$ voor grondbezitters, en voor hen, die van de scheepvaart leven, 3 rijksdaalders (D. 13 nov. 1659). Deze dreigende belasting benauwde de kustbewoners, doch in Mataram dacht men nergens anders aan ,als om middelen om gelt voor den Sousouhounangh te versamelen".

Toch zag de Vorst wel in, dat hij geen grote rijkdommen zou verwerven, alleen door arme onderdanen zwaar te belasten. Er diende geld verdiend te worden en wel op de Nederlandse wijze. Vandaar verschillende plannen om met medewerking zijner groten overzeese handel te drijven.

De eerste poging daartoe is de instelling van een handelsmonopolie.

Het monopolie der vier strandheren. 1657.

Vreemd doet het aan te vernemen, dat ,door de grooten aen de zeekandt ende desselfs gebiets jalousie meerendeele het toeblijven tot 
noch (toe) in eenige harer havenen veroorsaeckt" was (D. 26 febr. 1657). En nogmaals wordt het trage ontsluiten der havens geweten aan de ,jalousie der strantheeren" (D. 6 mrt. 1657 p. 114). De Vorst wenste niet, dat de strandgebieders ,soo oneenich waren, sulcx oock tot het opendoen der havenen niet gevordert hadde".

Wat onder deze gewenste eensgezindheid der strandheren verstaan wordt kan men opmaken uit hun normaal gedrag, n.l. het wederzijds elkaar belasteren wegens verboden leverantie van rijst en dgl. naar Batavia (D. 3 mrt. 1657 p. 111). De Sunan wenst, dat zij in handelszaken één lijn trekken, m.a.w.: monopoliseren. Pas wanneer de heren het over een handelsmonopolic eens zijn geworden, mogen de havens open.

Toen de reeds vermelde Truijtman vóór 1 apr. 1657 in Japara kwam, werden alle zeehavens geopend. Overal werd hij goed onthaald, vooral door tg. Patii, met wie hij in de dalem te Japara, evenals met de andere drie strandheren en vier gecommitteerden van de Sunan in gesprek was geweest (D. 17 apr. 1657). Ook was hij ,op derselver voorslach" naar diens woning in Pați gereisd. De bedoeling van al deze vriendelijkheid was, dat voortaan alles, wat vandaar naar Batavia zou vervoerd worden „van haer alleen soude moeten gecocht werden", hetgeen volgens Truijtman een nieuwigheid was (Rapport Truijtman K.A. 1110, f 785). Tot dit voorstel had echter Truijtman, ,als te seer naer monopolie smakende... niet... connen verstaen", allerminst na het vernemen der vaste prijzen. Deze, vergeleken met de vroegere prijzen, waren als volgt:

„Rijst van 15 tot 30 ra. de cojangh, swarte suijcker van 7 à $71 / 2$ tot 15 de 10 picol, witte do. van $21 / 2$ à 3 tot 4 ricxd. 't picol, plancken van 15 à 20 tot 30 ricxd. 't cento, balcken van 20 à 22 tot 30 realen 't cento, sout van 5 tot 15 ra. 't last".

Dit zijn dus verhogingen van ca. 30 tot $200 \%$.

Truijtman deed nu, of zij „,met hem waren boertende” en dreigde met vertrek. $\mathrm{Na}$ vele redekavelingen vertrokken de vier strandheren onverrichterzake elk naar zijn standplaats, „met aensegginge op sijn saecke nader wilde(n) pitsjaeren".

Op uitnodiging van tg. Pați had Truijtman zich toen weer naar Pați begeven, onder voorspiegeling van hout en zout, en was er zeer „minnelyck ontvangen” (D. 27 apr. 1657). Hij mocht zelfs in de dalem logeren. De bovenstaande prijslijst, zo vernam hij, was wel door de 
strandheren opgesteld, maar het houtwerk viel er buiten, dat „meest in sijn Patij's als sijn vrundts Sourianata's gebiet viel". Daarom beloofde de tumenggung de houtprijzen niet te verhogen. Dit was de eerste bres in de monopolievesting. Spoedig bleken de vier strandheren tot Truijtman's genoegen het over het monopolie oneens te zijn (D. 27 apr. 1657 p. 150-51). Er kwam in feite niets van terecht, hetgeen hun positie ten hove niet ten goede zal zijn gekomen.

Toen Truijtman op 26 juni 1657 te Batavia terugkeerde en rapport uitbracht, bleek daaruit, dat niet alleen de havens heropend waren, maar dat ook ,alle nieuwicheden bij de vier strantheeren gesocht in te voeren, geheel afgedaen ende op den ouden voet den handel aldaer weer in gangh gebleven" was (D.). 1

\section{Verboden handel. 1657-58.}

$\mathrm{Na}$ de mislukking van het handelsmonopolie sloeg de Sunan een andere weg in: hij vertrouwde zijn strandheren geld toe, om er winst mee te maken.

Op 24 juni 1657 waren te Samarang gecommitteerden uit Maatram gekomen, die de vier strandheren ontboden en ieder 10.000 realen ter hand stelden, „om daermede te negotiëren ende de Maijesteijt ider weder twintich in de plaetse te leveren binnen 't jaer" (D. 20 juli 1657).

Men kan zich voorstellen, dat deze moeilijke opdracht de weinig commercieel aangelegde Javaanse aristocraten in grote verlegenheid bracht. Begrijpelijk is, dat zij ieder middel aangrepen, om aan de eis van hun heer te voldoen, en ook niet al te kieskeurig konden of wilden zijn. Zo zou een Chinees te Djuwana de strandheren hebben wijs gemaakt, dat in de handel „op d'Oost als... op de Malacxe tinquartieren... ongelooffelijcke winsten waren te doen". Een bezwaar

1 Hoe fel men destijds op geld was, blijkt uit het kortstondige geschil over Chinese nalatenschappen. Door een Chinees zou tg. Pați misleid zijn omtrent Compagnies gebruik dienaangaande. De vroegere Gouverneur-Generaal zou n.l. middelen der in Batavia overleden Chinezen ,vrij (hebben laten) volgen”. Doch sedert Maetsuyker's optreden in 1653, ,soo neemt hij alle haere middelen weder”. Daarom verzocht tg. Pați: „Indien hij ons beminne... hij geve alle haere middelen weder, want in mijne stadt ende in Batavia ende in alle de coopplaetsen Chinesen in groote menichte sijn,... waerom ick begere... dat het haer weder werde gegeven". Na nadere toelichting door de Hoge Regering had tg. Pați ,zich op 't hoogste geëxcuseert" over deze onjuiste antijging. Hij bevond, dat het maar leugens waren en wenstc. er niet over geschreven te hebben (D. 10 ov. 1657 p. 308). De aan deze laster schuldige Chinees was begin nov. 1657 overleden (D. 17 nov. 1657 p. 314). 
was hieraan verbonden: de Compagnie beschouwde deze gebieden als voor Javanen verboden vaarwater. Daarom verzochten de vier strandheren de Hoge Regering, om met de oostmoeson naar Malaka en de tinkwartieren en in de westmoeson naar Amboina handel te mogen drijven (D. 25 aug. 1657). Tg. Pați vroeg drie passen en vrijgeleide voor drie vaartuigen om „nae de verboden plaetsen te mogen vaeren, t.w.: Banda ende Amboina, alsmede nae de plaetsen ... onder de gehoorsaemheijt van Atchijn" (D. 3 sept. 1657 p. 253). Ng. Wangsa-Radja van Samarang vroeg hetzelfde voor vijf vaartuigen, wier bestemming de Zuid-Molukken was.

Het lang uitblijvende antwoord der Hoge Regering hadden de heren niet afgewacht, want op 1 sept. 1657 meldde de resident, dat de strandheren „begonden sonder passen naer de thinquartieren te vaeren”. Die van Samarang had één en die van Djuwana (tg. Pați) had reeds twee kontings gezonden met geld tot opkoop van kleden. De Chinezen hadden hun wijs gemaakt, dat Malaka wel zonder pas te passeren was (D. 8 sept. 1657).

Dat dit een energieontplooiing tegen wil en dank was, blijkt wel uit de verzekering van tg. Pați, dat hij ,'t selve genootsaeckt was te doen, aengesien het d'andere heeren mede deden". Zijn heer zou het hem kwalijk nemen, als een ander meer won dan hij.

Het resultaat dezer verboden handelstochten wordt niet vermeld. Vermoedelijk was het niet veel, daar de gouverneurs van Japara en Pați eind 1658 de Hoge Regering om passen voor Amboina en Queda (Kedah) verzochten (D. 9 jan. 1659). Dit verzoek werd op onvermogen geheel afgeslagen (res. 9 jan. 1659 p. 4). In dit opzicht was Batavia onwrikbaar.

Doch niet enkel tot de Archipel beperkte zich de Javaanse handelsdrift, zij droomde ook van handel op Voor-Indië, waar de fraaie kleedjes vandaan kwamen.

\section{Handelsreizen met Westerse hulp. 1657-_-59.}

Daar de Javanen de kust van Koromandel niet met eigen krachten konden bereiken, riepen zij de Westerlingen te hulp. Reeds in 1651 was aan een dienaar van de gouverneur Astra-Siapa een pas verleend, om met een Hollands schip naar Koromandel te varen.

$\mathrm{Na}$ de eerste havensluiting werd van deze reizen meer werk gemaakt. In een schrijven aan de Gouverneur-Generaal berichtte tg. Pați, dat de Sunan hem bevolen had, een gezant naar de kust van Koromandel 
te zenden (D. $3 \mathrm{mrt} .1657$ p. 112). Hij verzocht voor deze passage op een Compagnies schip. Toen het verzoek blijkbaar genegeerd werd, herinnerde de tumenggung er enige maanden later op kiese wijze aan. De gezant, blijkbaar iemand van Java's noordkust, moest eerst voor de Vorst verschijnen. Als hij weer in Djuwana terug was, zou hij het de Gouverneur-Generaal laten weten (D. 27 juni 1657).

Daar de Hoge Regering ook deze stille wenk voor kennisgeving aannam, verzocht tg. Pati de Japarase resident hem te waarschuwen, als er schepen naar de Kust zouden varen. Evert Michielsen antwoordde hierop, dat die al weg waren. „Ondertusschen woude vertrouwen, dat dien voorslach soude... verouwen ende te niet loopen" (D. 8 sept. 1657 p. 259).

De tumenggung heeft zijn verzoek stellig niet voor de vierde maal herhaald, althans het volgende jaar werkten de Javanen met de Engelsen samen.

In 1658 moet volk van de Sunan op een Engels schip naar Koromandel gevaren zijn, hetgeen blijkt uit een bericht in Dagregister 11 juli 1659, meldende, dat op 14 of 15 juni daaraan voorafgaande 3000 realen in specie van de Sunan gekomen waren, ,om met syn volck met den Engelschman desen jare wederom naer de Cust (van Koromandel) te gaen tot opcoopen van cleeden".

Daartoe behoorde blijkbaar ng. Marta-Nata's secretaris, daar deze met slechts drie anderen naar de Kust vertrokken was, ofschoon de kapitein beloofd had, er twaalf te zullen meenemen (D. 21 sept. 1659 p. 196). Daarom verzochten de Javanen de Compagnie nog vier man op een Nederlands vaartuig te vervoeren (D. 20 aug. 1659). Dit werd wederom geëxcuseerd: de moeson was verlopen en voorlopig ging er geen schip meer derwaarts.

Tegen de weigering der Nederlanders stak de medewerking der Engelsen gunstig af. Geen wonder, dat hun toegestaan werd opnieuw een loge in Japara te stichten (D. 21 juni 1659). $\mathrm{Zij}$ handelden er reeds, sleten 15 pakken kleden aan de gouverneur, die ze snel verkocht en toen pas betaalde.

De oude Engelse loge, reeds lang door de omwonenden van haar pagger beroofd, kreeg er op ng. Marta-Nata's bevel opnieuw een. Ook het door lang leeg staan sterk vervallen logegebouw zou hij laten herstellen (D. 7 oct. 1659). Door de havensluiting van 1660-62 zullen deze plannen wel tijdelijk van de baan zijn geraakt.

Een tegenhanger tot deze Koromandelse vaart met Engelse hulp is 
een overeenkomst tussen tg. Pați en orangkaja Bulan. Deze laatste is ongetwijfeld de Ambonse orangkaja van die naam, welke herhaaldelijk in Valentijn (II, ii 149, 150, 172, 210, 219) voorkomt. In 1645 was hij tot Nusatapi aangesteld; in 1662 overleed hij. Ofschoon verdacht van samenwerking met de Ambonse rebellen, spaarde de Hoge Regering hem om zijn grote invloed. Een twijfelachtige figuur dus.

Deze orangkaja Bulan had van tg. Paṭi voor 200 rds. een vaartuig gehuurd, dat hij beloofde ,jachtsgewijs toe te takelen". Daarna zou hij er mee naar Amboina varen, onder voorwaarde, dat ieder het schip voor de helft zou laden.

Orangkaja Bulan was in het najaar van 1859 naar Amboina teruggekeerd, zonder Djuwana aan te doen. Wel kwam hij in Japara en liet daar het vaartuig achter. Tg. Pați kon het daar moeilijk gaan halen, omdat zijn aartsvijand, ng. Marta-Nata er de baas was (D. 15 dec. 1659).

Ook deze poging om verkapt op de verboden Molukken te varen, bracht moeilijkheden met zich mee. Opvallend is ook hoe nu een jachtsgewijs getuigd schip een rol speelt. Jachten waren voor de Javanen de eerste, moeizaam te bestijgen trede van de Oceaanvaart.

Bouw van jachten. 1652-59.

De scheepsbouw, die de Nederlanders in 1651 op Java's Noordkust begonnen waren, heeft al spoedig de Javanen tot navolging verlokt. Reeds in 1652 vernam men van twee in aanbouw zijnde jachten, die de Sunan voor de vaart op Taiwan of Koromandel bestemd had (H.R. 11 juli 1652 T.B.G. LX, 155). Aangezien men over werkvolk beschikte, dat bij de bouw van Compagnies jachten meegewerkt had, meenden de Javanen het nu ook wel zelf te kunnen.

Twee jaar later was men blijkbaar nog niet erg opgeschoten en vroeg men de Compagnie een scheepstimmerman ter leen. Daar Batavia de Javanen niet al te wijs wilde maken, werd het verzoek op grond van gebrek aan volk afgewezen (v. Goens 151). Deze weigering ontmoedigde de Javanen niet. De gouverneur ng. Marta-Nata had de leiding. Twee schepen werden op stapel gezet, doch de bouw was gans mismaakt. Bij het aflopen was het grootste, alvorens zijn element te bereiken, omgevallen en aan één zijde gebarsten (Rapport Truijtman K.A. 1110 f. 785 en vlg.). Het andere was te water gelaten maar van een dgl. onbehouwen vorm, dat de Nederlanders er ernstig tegen waarschuwden, met zulk een vaartuig naar Koromandel te varen. 
Toch zetten de Javanen door, op hoog bevel. Men had nu ten minste één schip, maar nog geen stuurman. Tg. Pați, de „Hollander” kreeg opdracht er een bij de Nederlanders te vragen (D. 3 mrt. 1657). Ng. Marta-Nata herhaalde het verzoek uitvoeriger, ,want de zee is groot ende de Javanen connen die niet beseijlen". Daarom verzocht hij land- en zeekundigen, "tot elcken prauw een Hollants stuijrman", want „sulx heeft ons den Sousouhounan aenbevolen” (D. 27 juni 1657). Ook werd om vier ankers verzocht (D. 27 apr. 1657), die geleverd zijn (D. 22 nov. 1657).

Of des Sunans jacht in 1657-58 Java verlaten heeft, mag ernstig betwijfeld worden. Zeker heeft het dat in 1659 gedaan, toen het een tocht naar Makassar ondernam. ${ }^{1}$ Met Makassar poogden de Javanen n.l. op handelsgebied samen te werken.

\section{Belangengemeenschap met de Makassaren. 1659.}

De samenwerking van Matarammers en Makassaren op handelsgebied is het werk van de gezant kodja Ibrahim geweest, want, zo wordt verhaald, „hy (was) den auteur van 't geheele werck” (D. 26 apr. 1659). De Japarase gouverneur, ng. Marta-Nata moet er sterk bij betrokken zijn geweest, daar de Sunan hem later de kwade afloop verweet.

Vermoedelijk dateerden die relaties reeds van de tijd, toen het plan beraamd werd des Sunans jacht naar de kust van Koromandel te laten zeilen, „op het groot opgeven van den Codja Ibrahim ende de Portugesen wegens de winsten... waernaer haer ooren jeuckten". Sedert waren zij van inzicht veranderd en zonden het schip naar Celebes om „op Macasser te vercopen, off wel een tocht naer de Manilhas... te laten doen".

Het vertrek van het vorstelijk jacht ging overigens niet van een leien dakje. Vóór 8 jan. 1659 was order van de Sunan gekomen om zijn jacht, groot 70 last, zeilvaardig te maken voor een tocht over Makassar naar Manila (D. 28 febr. 1659 p. 38). De ,aenwesende paep, Codja Ibrahim van Macassar" had hiervan ,grote dingen opgegeven". Daarom zal hij het Makassaarse gezantschap op zijn hofreis vergezeld en de Sunan persoonlijk voor deze expeditie warm gemaakt hebben. Pas ultimo februari vertrok het vaartuig in gezelschap der Makassaren (D. 26 apr. 1659 p. 79). Het schip was met Javaanse koopwaar geladen

\footnotetext{
1 Voorts beraamde de Sunan nog de bouw van een galei, waartoe touwen, zeilen, ankers en ijzeren bouten ontbraken. Hiervoor werd eveneens de huip van de Gouverneur-Generaal ingeroepen. (D. 27 juni 1657 p. 198 -99).
} 
en aan boord bevonden zich, behalve gezanten van de Sunan, twee goudsmeden, om welke de vorst van Makassar waarschijnlijk verzocht had. Mogelijk voeren ook enige Portugezen mede, die beter dan de Javanen dit voor dezen vreemde vaartuig konden besturen. Tussen deze beide volkeren was destijds de verhouding verre van slecht (D. $28 \mathrm{febr}$. 1659 p. 37). Toch heeft deze samenwerking op handelsgebied tot niets geleid.

Ofschoon kodja Ibrahim er door de opkomende oostmoeson niet in geslaagd was Makassar te halen, was dit wel aan de overige Makassaarse gezanten gelukt, zo mede aan het Javaanse vaartuig, dat hen begeleidde. Het verkopen van dit jacht en zijn lading had heel wat voeten in de aarde. De bemanning diende in Makassar te blijven, zo lang kodja Ibrahim niet terug was, wellicht als gijzelaars. Daarop had de broeder van ng. Marta-Nata aan kodja Ibrahim volk een vaartuig aangeboden en gelast te vertrekken. Deze had dit echter voor onmogelijk verklaard (D. 11 juli 1659). Pas omstreeks 24 nov. 1659 is hij, toen de westmoeson doorbrak, vertrokken.

In Makassar ging het de Javaanse gezanten niet naar den vleze. Zij werden er niet ,naer merite... onthaelt ende getracteert" (D. 21 sept. 1659). Ook mochten zij niet naar Manila varen, zodat zij naderhand hun meeste koopwaar terugbrachten. Met hen keerden ook de beide uitgezonden goudsmeden terug. De Sunan vroeg dezen, „wat (zij) daer al voor eere genoten... ende geschencken medegebracht hadden". Hun antwoord luidde, dat $\mathrm{zij}$,,voor de princen hadden moeten wercken op haer eygen kosten, zonder de minste loon, sulcx (zij) al 't geen (zij) mede gebracht hadden, hadden moeten verteren". Evenmin was de gezanten ,groot eere aengedaen”, terwijl een tegengezantschap uitbleef.

Daarop zou de Sunan hevig tegen ng. Marta-Nata zijn uitgevaren.

Niet alleen op politiek, doch ook op economisch terrein was de Makassaars-Mataramse samenwerking tot mislukken gedoemd.

\section{Gezamenlijke paardenaankopen. 1657-58.}

$\mathrm{Nu}$ geen Nederlandse gezantschappen meer naar de hofstad kwamen, was het de taak der vier strandheren 's Vorsten paardenstal van nieuw bloed te voorzien.

Van 8 aug. tot 5 sept. 1657 ontving de Hoge Regering van elke strandheer twee vaartuigen, waarop gezanten met brieven. Hierin werd om paarden verzocht die, naar zij beweerden, de Sunan hun gelast had te kopen (Demak: D. 8 aug. 1657; Japara: D. 25 aug. 1657; Pați: 
D. 3 sept. 1657; Samarang: 5 sept. 1657). Aan elk werd het verzochte verstrekt (Demak: D. 18 aug. 1657; Japara: D. 8 sept. 1657; Pați: D. 26 sept. 1657; Samarang: D. 1 oct. 1657).

De aangekochte paarden zijn niet in de smaak gevallen. Volgens de tolk Michael Zeeburgh wist de Sunan van de hele bestelling niets af (D. 4 dec. 1657). Daar één paard ondertussen schijnt te zijn gestorven, werden drie paarden naar de Kraton gebracht. Volgens de brief van ng. Marta-Nata (D. 22 nov. 1657) had de Vorst gevraagd: „Van waer sijn dese paerden?” waarop was geantwoord: „Het sijn paerden van Batavia, die de Gouverneur-Generaal ende alle d'grooten van Batavia hebben gegeven”. Hierop hernam de Sunan: „Dese paerden en gevallen mijn niet!" De dienaren antwoordden weer: „Daer en sijn geen paerden op Batavia, die beter sijn dan desen, want alle, die wij afgesonden hebben, hebben dese paerden op Batavia uijtgekosen; daer en sijn geen beter dan dese drie paerden". Maar de Vorst sprak toornig: „Ende en sijn mij niet aengenaem; ick wil selfs na Batavia senden, om paerden te soecken".

Toen werden zes lurah's gezonden, die bij de Sunan in aanzien stonden en toezicht hielden op zijn paarden. Hun namen, ofschoon driemaal in het Dagregister opgenomen (D. 17 nov. en 22 nov. 1657) luiden slechts in twee opgaven gelijk: Tjitra, Oedjos of Bediouw, Asta, Nala, Naja en Suta-Karti. De derde lijst heeft, behalve Bediouw en Nala, nog vier andere namen: Wangsa-Gati, Sarangga, Babakaija Kiaffa (?) en Nala-Gati.

Ng. Marta-Nata had, om deze ,stalmeesters aensienelijcker te maecken, als om haer ten dienst te staen” hun medegegeven „sijn ouden sabandar Astanaija” en een zijner dienaren Nala-Pada, die „Portugées ende Duijts spreeckt", terwijl tg. Pați een sjabandar van Djuwana, Wangsa-Taka aan het gezelschap had toegevoegd (D. 17 nov. 1657).

Vijf dagen later verschenen weer ,expressen” der vier strandheren, van wie twee, die van Japara en Pați, het verzoek hunner heren schriftelijk overbrachten, terwijl de overigen zich tot een mondelinge boodschap beperkten. De bode uit Demak bracht het geleverde paard zelfs terug, daar de Sunan het wat te klein zou hebben gevonden (D. 20 nov. 1659).

Ongetwijfeld zal de Hoge Regering de zes Mataramse stalmeesters in haar paardenstal hebben toegelaten, hoewel deze ditmaal niet rijk voorzien was. Dit was te wijten aan een plotselinge sterfte onder de viervoeters, uitgebroken op kerstdag 1657 (D.). Drie dagen later waren reeds 20 paarden dood (D.). Waarschijnlijk hebben de Javanen daardoor 
niets kunnen krijgen; hierop wijst, dat enige maanden later opnieuw, doch wederom te vergeefs, om paarden werd gevraagd. De vier strandheren lieten in juli 1658 hun „expresse afgesondene" naar Batavia varen met ,versouck... dat haer ijder een schoon Persisch paert, bequaem om aen den Sousouhounangh te presenteren, mocht vercocht werden" (Res. 15 juni 1658 p. 69). Het werd hun niet toegestaan, „vermits de grote sterfte... onder Compagnies paerden”. Zij dienden schepen uit Perzië af te wachten, die er zeker zouden aanbrengen.

Aangezien het jacht de „Mars” kort daarop vier paarden meebracht en de nog niet vertrokken Samarangse afgevaardigden daarvan gehoord hadden, verzochten zij dringend om één paard. De Hoge Regering meende dit verzoek niet te mogen weigeren, opdat deze lieden zich nog des te meer aan de Compagnie verplicht zouden voelen. $\mathrm{Zij}$ mochten dus, tegen betaling van 300 realen, één paard uitkiezen.

De bijzondere geschenken. 1656-59.

Volgens tg. Patii zou van de strandheren de „,beste man wesen, die het meeste opbracht" (D. 7 dec. 1656). Doch ook met zeldzame of wonderlijke geschenken trachtten zij het hart huns meester te winnen; van deze zaken was de Compagnie natuurlijk de aangewezen leverancier.

Zo verzocht tg. Pați, voorziende ten hove ontboden te zullen worden, „cleeden, felpen (fluweel), lakenen stoffen”, zo mede vier ,glasen landtarens met geschildert glas" (van Chinese makelij?) ter waarde van 2000 realen. Hij beloofde met rijst, zout en houtwerken te betalen.

Gelijktijdig ontving de Hoge Regering een schriftelijk verzoek van tg. Patit's mededinger, ng. Marta-Nata om een haan, „,want de Sousouhounan van mijn een haen ... begeert". In ruil voor één of twee exemplaren bood de gouverneur 1300 ,uijtgesochte clappussen” aan; „en gelieft d'selve niet te versmaden, het is slechts als een bloemtien" (D. 8 sept. 1657 p. $259-61$ ).

Welke waarde aan de verwerving van zulke curiositeiten werd gehecht, blijkt uit het volgende.

Op 23 dec. 1658 verscheen ng. Marta-Nata „met alle syne swite" in de Nederlandse loge, waar hij naar behoren ontvangen en onthaald werd (D. 10 jan. 1659).

Naar Javaanse trant viel de gouverneur niet met de deur in huis, doch verklaarde op des Sunans bevel gekomen te zijn, ,om de logie te besichtigen, ende in welcker doente de Hollanders aldaer haer waren onthoudende". Dadelijk bood de waarnemend resident Evert van Hoorn 
aan, alles te vertonen, hetgeen geweigerd werd. Hieruit trok de resident de wel wat voorbarige slotsom, dat het ,dien heer nergens anders om te doen was, dan om een welcomgift, dat (hij) dan naer oud gebruyck gedaen hadde" (D. 28 febr. 1659 p. 37-38).

Dit was echter niet alles, want hierop deelde kj.ng. Marta-Nata mede, de dag te voren van de Sunan een brief te hebben ontvangen, „waerby expresselyck van hem was vorderende een kameel ende een bocrom lasker". Evenmin als wij wist de gouverneur, wat dit laatste voor een dier was, maar hij verzocht het voor hem te Batavia te bestellen. Er was haast bij, want hij wou het mee naar boven nemen.

Ook Van Hoorn verklaarde zulk een beest nooit gezien te hebben, waarna de gasten vertrokken.

Van Hoorn's schrijven hierover werd door de lurah's Sabda-Wangsa en Djiwa naar Batavia gebracht, mèt een Maleise brief van de gouverneur. Hierin verzocht deze eveneens om ,eenige gedierten, met namen laskaer ende een paer kameelen". Ook wenste hij gobars, passend voor de Sunan, te kopen. Hij zond al vast 3 last rijst bij vooruitbetaling.

Op 15 mrt. 1659 (D.) antwoordde de Hoge Regering, dat kamelen niet voorradig waren, doch dat binnen 3 tot 4 dagen de koopman Evert Michielsen naar Japara dacht te reizen. Deze zou „,2 paer Suratse osies (zebu's?) met hare carretien" meebrengen. Waren deze dieren op Java nog zeldzaam?

Inderdaad keerde Michielsen op 19 mrt. 1659 (D.) naar zijn standplaats terug, waar hij zijn plaatsvervanger in de drank verstikt aantrof (D. 26 apr. 1659). Kort voor zijn sterven had deze onwaardige dienaar nog des Sunans boden, uitgezonden om de dieren in ontvangst te nemen, „seer onfatsoenlyck bejegent”. Michielsen daarentegen haastte zich zijn terugkeer schriftelijk aan de in de hofstad vertoevende strandheren bekend te maken, alsmede dat hij vier Suratse osjes met hun karretjes voor de Sunan meebracht; deze kon er om zenden. Inderdaad verschenen enige gecommitteerden om de ossen en karretjes, die Michielsen tevoren met rood laken had doen overtrekken. Zij vroegen, wat er nog meer bij was, vertrouwende, dat het een „formele schenckagie" voor de Sunan vormde.

Het geschenk viel dus in goede aarde, immers op 11 juli 1659 (D.) ontving de Hoge Regering van ng. Marta-Nata een brief, waarin deze de ontvangst ten hove bevestigde. $\mathrm{Hij}$ had ze zelf aan de Vorst overhandigd, die er zeer verblijd over was geweest. „Den Sousouhounangh ende syn vrou hebben daerop gereden tot aen de Segarajasa toe". Daarna vroeg de Vorst „na sulcke koebeesten ende bulleties mede 
(meer?) te willen hebben". Ook verzocht hij een goed paard en Surats gouddraad. Als tegengeschenk liet ng. Marta-Nata door zijn broeder Sabda-Wangsa $21 / 2$ last rijst en een hert aanbieden.

De ossekarretjes waren dus in de smaak gevallen en verhoogden ng. Marta-Nata's aanzien, daar hij zich de eer van dit geschenk toeschreef. Hoe machtig hij destijds geworden was blijkt wel uit zijn eigenhandige terechtstelling van zijn collega ng. Wangsa-Radja, gouverneur van Samarang, waarop wij terugkomen.

Deze aardige geschenken, door bemiddeling der Compagnie verkregen, mogen een ogenblik de stemming ten hove verbeteren, over het algemeen raken de vier strandheren steeds meer in het nauw door het mislukken hunner economische plannen. En bij wie zouden zij eerder om hulp aankloppen dan bij de schatrijke Compagnie, wier vertegenwoordiger binnen hun bereik in Japara woonde. Hierover zullen de volgende bladzijden handelen.

\section{Gemeenschappelijke geldnood. 1659.}

De schaduwzijden van het nieuwe systeem vielen op, toen het op afrekenen aankwam. De vier strandheren bleken weinig of niets te kunnen of te willen betalen. $\mathrm{Zij}$ gingen dus geld lenen en bij wie eerder dan bij de in hun ogen onmetelijk rijke Compagnie. Het sterkst viel de geldnood van tg. Pați en ng. Marta-Nata van Japara op.

Tegen de vastenmaand (april-mei 1659) eiste de Sunan van eerstgenoemde dadelijk alle inkomsten en tollen van Pați op. Daarom liet de tumenggung de Hoge Regering om 20.000 realen verzoeken; ,'t selve zal strecken tot behoudenisse van myn leven", schreef hij. Kreeg hij het niet, dan bestond de kans op ontslag en inbeslagneming van gans zijn bezit. Immers, de Sunan was "seer haestig om dat gelt te willen”. Ofschoon zijn broeder Wira-Wangsa deze bede overbracht, wees de Hoge Regering haar toch „op het beleeffste doenlyck" af, zich beroepende op onvermogen: het was tegen de instructies (D. 16 en 19 apr. 1659). Overwogen werd, dat het weigeren weliswaar moeilijk viel, doch dat het invorderen nog pijnlijker zou wezen. Bovendien waren er meer armlastige strandheren. Wel was de Compagnie bereid op rijst, suiker, peper, hout en dgl. geld voor te schieten (res. 16 apr. 1659 p. 67).

Niet ontmoedigd liet tg. Pați door zijn zoon Wira-Suta en een andere broeder nogmaals een verzoek om geld aan de resident toekomen, daar hij er zeer verlegen om was (D. 13 mei 1659). Hij beloofde er de levering van 200 grote balken ter waarde van 1-2000 realen tegenover te stellen (D. 15 mei 1659). De uitgezondenen hadden zelfs last om de loge niet 
te verlaten, tenzij zij met 1-2000 gulden geholpen werden. $\mathrm{Zij}$ waren toen 1 tot 2 dagen in de loge blijven hangen, waarna de resident genoodzaakt was hun ,op leverantie van 300 aenbestede balcken 500 rijksd. ter hant te stellen", onder belofte, dat bij de komst van het eerste schip er 100 gereed zouden liggen.

Een half jaar later was de toestand weinig verbeterd (D. 13 nov. 1659 p. 226). Tg. Pați zond per eigen vaartuig lurah Naja naar Batavia met 500 pikol witte suiker en andere eetwaren. $\mathrm{Hij}$ verzocht ze marktgangs af te nemen, ,alsoo (hij) ten hoochsten om gelt verlegen was, om den Sousouhounangh te betalen, alsoo nergens geenige penningen wiste ter leen te becomen" (D. 13 en 19 nov. 1659).

Ook in Japara steeg de nood, maar de gouverneur, geen Compagniesvriend, aarzelde, eer hij te Batavia aanklopte. Voorlopig poogde hij het ontbrekende van zijn onderzaten te krijgen (D. 21 mei 1659): „Het afparssen van gelt van de ingesetenen bleeff noch even hart continueeren". Men vertrouwde, dat er bij het begin of het einde der puwasa (aug. 1659) wel een regeringsverandering zou plaats vinden. Op dit feest plachten de groten hun schatting ten hove aan te bieden en een tekort zou natuurlijk tot pijnlijke mutaties aanleiding kunnen geven.

Toen de ingezetenen van Japara blijkbaar kaal geplukt waren, wendde men zich tot de Compagnie. Ng. Marta-Nata zond zijn zoon bagus Puspa-Raga naar Batavia om een 3 tot 4000 rds. te lenen, ,also den Sousouhounangh voor desen my gelt gegeven heeft, 't selve moet ick nu wederom uytkeeren, daertoe ick noch wat gelt te cort come". Plechtig beloofde hij het geleende met houtwerk, witte suiker enz. te vergoeden. Zelfs wilde hij er een jacht voor bouwen (D. 3 juni 1659 p. 116).

Drie maanden later is zijn aanvraag - ditmaal tot de resident gericht - tot 1000 realen gedaald, op leverantie van hout. Michielsen had het ,geëxcuseert ... op onvermogen” (D. 21 sept. 1659 p. 195).

Zo zullen de om geld verlegen Javaanse aristocraten in den regel bot gevangen hebben bij hun pogingen, om van de Compagnie geld los te krijgen. Deze instelling was niet gewoon haar kostbare contanten in een bodemloze put te werpen.

Ook kleinere machthebbers vielen Batavia met dergelijke verzoeken lastig, zoals de opperste van Batang, kj. ng. Niti-Juda, die 3500 rds. vroeg (D. 3 juni 1659); kentol Wira-Suta van Pekalongan, die wat geld nodig had; Singa-Perbangsa van Krawang, die 1000 rds. behoefde. (D. 16 dec. 1659). Geen hunner oogstte succes, hetgeen ontmoedigde. De volgende jaren merkt men veel minder van deze bedelarijen, ook al 
werden de strandheren nog vaak om achterstallige tollen en schattingen gemaand.

Maakte dit weigeren van geld de Compagnie al weinig populair, de tolkwestie deed de Javanen al evenmin voor haar in liefde ontvlammen.

\section{De kwestie der tollen.}

Op den duur griefde het de Javanen zeer, dat de Compagnie in Japara geen tol betaalde. Het eerst horen wij over deze tolvrijheid in Van Goens' rapport betreffende zijn derde reis in 1652 (v. Goens 112-13). Hij verhaalt daarin dat hij, nadat er 50 realen voor het last rijst gevraagd was, eindelijk de prijs trof van 14 realen het last, ,ende den tol vry geschonken".

Deze tolvrijheid bleef ook de volgende jaren. De Nederlanders waren van tol „exempt”, doch overwogen, dat zij de rijst van de plaatselijke gezaghebbers veel te duur kochten, t.w. tegen 15 inplaats van tegen 8 realen het last (H.R. aan Volsch dd. 5 mrt. 1655 K.A. 782 p. 8). Op deze wijze onthield men de Sunan zijn rechtmatige tol.

Overigens liet de tol de gouverneurs verre van koud. Men wilde in 1655 de hele Japarase tol, dus ook die van de niet-Nederlanders, aan de Compagnie voor 10.000 realen verpachten, doch zij weigerde. Hoe zou zij, in Japara geen gezag uitoefenende, op wanbetalers druk kunnen uitoefenen? Gevreesd werd, dat de gouverneur ng. Marta-Nata die weigering zou aangrijpen, om ook van de Compagnie „des Conincx gerechtigheijt" af te eisen. Voorlopig bleef het hierbij.

Maar zelfs de Hollandsgezinde tg. Pați liet zich, hoewel in een dronken bui, ontvallen, dat van ieder schip 1000 realen tol zouden geheven worden (D. 7 dec. 1656 p. 32). De resident, Evert Michielsen, ging daar ,wijtluftich" tegen in en stelde, dat àls er tol betaald moest worden, men „dan oock met een ijgelijck handelen (mocht) en niet juist aen de grooten, gelijck den tommagon voorsloech". Dit zou dus een combinatie zijn van tolbetaling met onbeperkte handelsvrijheid in plaats van tolvrijheid met beperkte handel.

Op deze tolkwestie wordt hierna teruggekomen (blz. 135).

De kredietweigering en de kwestie der tollen zullen de strandheren de weg gebaand hebben, om de Compagnie van het mislukken hunner financiële transacties de schuld te geven. In ieder geval behoefde zij niet meer op hun goede wil te rekenen. De positie der Nederlanders in Japara werd wankel. Hun tijdelijke verwijdering uit Japara ging echter niet rechtstreeks van de strandheren uit. 
Bedreiging met ontruiming. 1659.

Van een ontruiming der Nederlandse loge te Japara is het eerst sprake tijdens het tweede Makassaarse gezantschap, toen tussen de Sunan en de vorst van Makassar een verbond gesloten werd. Destijds schijnt er in de hofstad een sterke anti-Nederlandse wind gewaaid te hebben, dank zij het samenvallen ener Nederlandse actie tegen Palembang met het stoken der Makassaarse gezanten (D. 26 apr. 1659). Bovendien had de Japarase gouverneur, ng. Marta-Nata, vermoedelijk tijdens een raadsvergadering er op gewezen, dat de Nederlanders nergens tol van betaalden, terwijl de Javanen in Batavia dit van alles moesten doen, zelfs meer dan vroeger, n.l. 6 realen per last rijst. Daarom zou de Sunan bevolen hebben, „om de Hollanders van Japara op te seggen”. Tg. Pați had dit bevel sterk bestreden, zodat het niet uitgevoerd was. Ten slotte was hem gevraagd, of de Hollanders er wel 10.000 rds. per jaar voor over hadden, als ze in Mataram de vrije handel kregen. Toen de tumenggung verklaard had, dit niet te weten, was hij voor een „bottert" uitgescholden en had men hem gelast, alle vaartuigen gereed te maken, om daarmee naar Bali te gaan! Toen was gebleken, dat deze oorlog, t.w. die tegen Bali, voortsproot uit de strijd van Palembang met de Compagnie, het stoken der Makassaren en de klachten van ng. MartaNata. Men mag zich afvragen, of men niet in plaats van Bali, Batavia moet lezen en of de tumenggung niet uit beleefdheid deze naam verzweeg, toen hij van een en ander mededeling deed aan de naar Paṭi ontboden waarnemend resident Van Hoorn. Deze was met een bootje over het ondergelopen land bezuiden de Muria gevaren, na eerst Mataramse gezanten, die de bestelde Suratse osjes (zebu's) kwamen halen, zeer onfatsoenlijk bejegend te hebben. Het wekt verbazing, dat hij van de woorden van tg. Pați nog behoorlijk kennis had kunnen nemen, daar hij uit afkeer van het vele water zich met sterke drank vol gegoten had. Dat het inderdaad op de Compagnie gemunt was bewijst wel de vraag van de tumenggung aan Van Hoorn, welke sterkten de Compagnie in Amboina had en hoe groot de garnizoenen waren. Van Hoorn had daarop geantwoord, dat er 15 tot 16 sterkten lagen met een 7 tot 8000 Hollanders, die voor 4 tot 5 jaren van voedsel voorzien waren. De tumenggung had daarop het hoofd geschud en de beschonken Van Hoorn gelast te vertrekken om spoedig alles aan de Gouverneur-Generaal bekend te maken. Het gereed maken der schepen werd ondertussen ernstig voortgezet.

Dat deze mobilisatie niet in de eerste plaats tegen de Baliërs, doch tegen de Nederlanders bedoeld was, blijkt ook uit het bericht bij 
Rumphius over het vaardig maken van 20 schepen te Sura-Baja in verband met een Matarams-Makassaars verbond.

Gelukkig voor het aanzien der Compagnie stierf Evert van Hoorn spoedig op 25 febr. 1659, ,daer apparent hem door den overvloedigen dranck als verkort hadt", een verwarde boekhouding achterlatende. Het weder optreden van de bekwame resident Evert Michielsen kan de verhouding met Mataram slechts verbeterd hebben. Van een definitieve breuk was nog geen sprake. De gouverneurs vroegen geld te leen en in Japara verschenen twee ,gecommitteerdens, als Prana-Juda ende Anga-Raxa, beyde pagies van den Sousouhounangh ende gewesen contrerolleurs van den Japaersen gouverneur" (D. 13 mei 1659). Waren dit tugurs van de vroegere opperstrandheren? Het woord „pagies” kan op ganḍek wijzen.

Ze eisten geen 10.000 rijksdaalders per jaar, doch slechts logehuur vanaf 1651 à 10 rds. per maand, dus in totaal een 1000 rijksdaalders. Bij niet betaling konden de Nederlanders vertrekken. In die zin was al bevel aan tg. Pați gegeven, ofschoon hij, Prana-Juda, het bestreden had (net als vier maanden te voren tg. Pați). In ieder geval was de eis heel wat lager, dan die tg. Pați had medegedeeld. Het slechter worden der betrekkingen met Makassar kan deze matiging in de hand hebben gewerkt.

Intussen beweerde de Sunan van de Nederlanders niet méér voordelen te trekken dan van andere particulieren; rariteiten en dgl. kon hij ook wel van elders krijgen. Ook was er geen gezant meer volgens contract Z.M. wezen begroeten, hoewel het heus niet om een geschenk te doen was, „maer eenelyck de Mayt. souden (er)kennen”. Verder werd gevraagd, of de Compagnie soms een loge te Gresik of Sura-Baja wilde maken. Binnen drie dagen werd antwoord verwacht.

Michielsen antwoordde, dat de loge met toestemming van de Sunan, op eigen, hoge kosten der Nederlanders was gebouwd. Alleen op vorstelijk bevel wilden ze verhuizen. Kwamen er geen gezanten, dan was dit volgens wens van de Sunan. Over grondgelden, een nieuwigheid, zou naar Batavia worden geschreven.

De twee gecommitteerden bleven nu op antwoord wachten (D. $21 \mathrm{mei}$ 1659). Op 10 juni d.a.v. wachtten zij nog. Een maand later werd niet meer over de huur gesproken, zodat het zaakje schéén te zullen doodbloeden (D. 21 juli 1659). Dit was voorbarig optimisme van Michielsen. Ten slotte waren beide hofdienaren, zo lang de gouverneur afwezig was, met het bestuur over Japara belast.

Van de door tg. Pați en de beide tugurs overgebrachte aanmaningen 
trok de Hoge Regering zich niets aan, hetgeen met name de positie van eerstgenoemde ten hove zeker niet versterkt zal hebben. Men zal in Mataram geredeneerd hebben, dat als er met de Compagnies-gezinde tg. Pați t.a.v. Batavia niets te bereiken viel, krachtiger maatregelen nodig waren.

Geen wonder daarom, dat in deze dagen ng. Marta-Nata's aanzien aan het hof zeer sterk gestegen moet zijn, waartoe ook het zeer welkome geschenk der zebu's, die zowel in de smaak van de Sunan als die zijner gemalin gevallen waren, bijgedragen heeft. Nog hoger klom de ster van de Japarase gouverneur door de terechtstelling van zijn Samarangse collega, ng. Wangsa-Radja.

De dood van ng. Wangsa-Radja. 1659.

Ng. Marta-Nata's machtige positie blijkt duidelijk uit het doorsteken op last van de Sunan van zijn ambtgenoot in Samarang, ng. WangsaRadja, hetwelk ten hove plaats vond (D. 20 aug. 1659). Daarna daalde ng. Marta-Nata naar Samarang af om de familie van de gekriste gouverneur, diens broeders en vrouwen ,te disgraderen, haer crissen aff te nemen ende soo te laten lopen". Niemand hunner mocht zonder zijn toestemming de stad verlaten.

Ook had hij er nog een echtpaar gekrist, „een doctor ende doctoresse”, door „Wangsa-Radja... aen de Mayesteijt opgedragen”. $\mathrm{Zij}$ werden ervan beticht, ,dat met toverie omgingen ende met den duyvel te doen hadden".

Ng. Marta-Nata beweerde, dat ng. Wangsa-Radja omgebracht was, daar hij ,te hooch ende stout van moet was; oock 's Conincx middelen te liberael verschonck ende in syn huys te prodigael leeffde; oock den Coninck tegens veele ophitste". Hij had de "swarte meester ende meesteres" naar het hof gezonden om er achter te komen, wat daar voorviel, ,also zy met duyvelsweerdery omgingen". Zijn ernstigste vergrijp zou evenwel de slechte afrekening van het viende deel der 100.000 rijksdaalders geweest zijn, die de Vorst aan elke strandheer had toevertrouwd. Volgens de Nederlandse resident zouden de overige drie heren wel geen betere rekening kunnen maken. Behalve van ng. WangsaRadja werden ook van allen, die hij in het bestuur had aangesteld, rekening en verantwoording afgevorderd, terwijl men hen knevelde en mishandelde. 1

\footnotetext{
1 Volgens Michielsen's verslag over zijn reis naar Sura-Baja, is ng. WangsaRadja te Samarang opgevolgd door rangga Siḍaju, waarmede wellicht verband houdt, dat blijkens D. 5 sept. 1657 ng. Wangsa-Radja over Siḍaju te zeggen had.
} 
Echter meende Michielsen, dat ,indien hy Martanata maer daerby doot was, de Compagnie twee groote vyanden in dat ryck soude verloren hebben" (D. 21 sept. 1659); doch zover was het nog niet.

\section{De Nederlanders onder druk gezet. 1659.}

Toen ng. Marta-Nata, na de dood van ng. Wangsa-Radja op een hoogtepunt van zijn macht stond, poogde hij de Nederlanders te imponeren, om iets van hen gedaan te krijgen. $\mathrm{Hij}$ ontbood de resident Michielsen naar Samarang, doch deze stuurde zijn assistent David Luton, om zich te excuseren. Het afladen van een groot schip, de „Westvrieslant”, voor Batavia hield hem vast. Hiermede nam ng. MartaNata geen genoegen. Hij liet zijn sjabandar „op alle vrundschap” verzoeken, dat hij toch naar Samarang zou komen, daar hij over veel te spreken had. Pas nadat het vaartuig afgeladen was, begaf de resident zich naar Samarang.

$\mathrm{Hij}$ werd er luisterrijk ontvangen (D. 16 sept. 1659). De gouverneur vond hij vergezeld van ,verscheyde strantheertjes ende gebieders... alsmede de affgesanten van Jamby”. In deze kring werd hij ,ongemeen feestelyck" onthaald (D. 21 sept. 1659). Ng. Marta-Nata verzekerde de resident, dat de "Sousouhounangh een groot vrunt van Capt. Moor ... was". Daarom mochten de Hollanders alles wat zij uit zijn land begeerden, vrij uitvoeren. In tegenwoordigheid van alle aanwezige heren verklaarde de gouverneur zelfs, „dat hy door den Hollander groot gemaect was", waarvoor hij ronduit wilde uitkomen. Daarom, als de Hollanders een verzoek hadden, moesten ze dat maar bekend maken en niets ter wereld zou hun geweigerd worden, ,maer alles soude voor de Compagnie openstaen". Immers, de Sunan had hem met een gouden sirihstel begiftigd en de gehele strandregering was hèm en tg. Paṭi toevertrouwd, ,derhalve het voortaen beter als wel voor desen soude gaen". $\mathrm{Na}$ deze loftuitingen meende het Nederlandse opperhoofd zijn kans te kunnen waarnemen.

Michielsen begon met ng. Marta-Nata veel goeds en geluks in zijn „,nieuwe regeringe" te wensen, „met verheffingen van syn loff etc.". Hij hoopte op diens spoedige terugkomst in Japara met het oog op de ondragelijke moeilijkheden, die de Compagnie er van zijn broeder te lijden had, zoals bij het kopen en uitvoeren van goederen, door het opsluiten van Compagnies dienaren en dgl. meer. Zelfs waren de goederen met nieuwe tollen bezwaard. Daarom wenste hij een geschrift, dat behelsde, wat de Compagnie op Java mocht kopen en uitvoeren.

Door dit verzoek verzwakte echter Michielsen zijn positie en 
ng. Marta-Nata greep deze kans. Hij stelde zich boos aan en gelastte zijn schrijver een eigenhandig getekende brief op te stellen, waarbij de Nederlanders „onbecommerde handel ... alomme" werd gegund, mits daarvoor de ,ordinaris tol" betaald werd, ,also 't selve een expresse ordre ende de wille des Sousouhounangs was" (D. 16 sept. 1659 p. 190). Ter vergulding der pil werd de Compagnie gegund te Mandalika in een groot bos 100 bomen te laten vellen. Eertijds mocht hieruit niet gehakt worden, omdat het voor de kielen en masten van des Sunans vloot bestemd bleef. Maar het plaatselijk hoofd kreeg nu zelfs last te zorgen, de bomen zo spoedig mogelijk af te brengen, „off dat het syn ruyne soude syn". Inderdaad werd het hout snel geleverd; er werkten een 100 man aan (D. 7 oct. 1659 p. 209).

Kennelijk was dit een listige poging, om de Nederlanders aan tolbetaling te gewennen, waarvan zij tot dusver verschoond waren gebleven. Dit moet ng. Marta-Nata èn zijn Vorst sterk verdroten hebben, evenals de weigering om op een houtleverantie 1000 realen voor te schieten (D. 21 sept. 1659). Trof de kredietweigering slechts de strandheren, de tolvrijheid griefde zowel de Vorst als zijn dienaren. Niet onmogelijk lijkt het, dat de armlastige gouverneurs juist deze laatste kwestie te berde gebracht hebben, om des Sunans aandacht van hun financieel te kort schieten af te leiden en de vorstelijke toorn zich op de hoofden der Hollanders te laten ontladen. Het is ook opmerkelijk, dat hij, die deze kat de bel aanbond, er ook het best afkwam, n.l. ng. Marta-Nata.

Diens positie was n.l. nog verre van sterk, ondanks zijn groot vertoon. Veel hing af van het behaalde succes. De Sunan had aanmerking op zijn gouverneur, wegens de geringe eer aan zijn gezanten in Makassar bewezen. Hij zou zelfs ,uytgevaren hebben...: Jae, Martanata, dit syn van $u(w)$ trouwe diensten, dat ick bespot werd, in plaats ghy my van Macassar soo veel wys gemaect hebt" (D. 7 oct. 1659). Maar deze wolk trok weer voorbij. Enige weken later vernam de resident door „dwerskyckers”, dat de ,gouverneur Martanata scheen van den Sousouhounang boven anderen ten hooff gecaresseert te werden, daerover vele vresen, dat hem 't selve wel qualyck opbreecken mocht, als zynde soo wel de gewoonte des Sousouhangs" (D. 13 nov. 1659). Inderdaad bestonden daarvan voorbeelden!

\section{Indruk van Palembang's verwoesting.}

Maar er overkwam hem voorlopig niets. Integendeel, 's Vorsten gramschap stortte zich over de Hollanders uit, en niet alleen over hen. 
De aanleiding tot deze uitbarsting vormde het conflict der Compagnie met Palembang.

Reeds werd opgemerkt, dat de Sunan voor het slepende geschil tussen de Nederlanders, zijn bondgenoten, en de Palembangers, zijn vazallen, grote belangstelling koesterde. Voor de vorm zou hij de eersten zelfs gelijk hebben gegeven, hoewel hij hun optreden in zijn hart afkeurde. Dit bewijst wel het onderzoek, dat hij tg. Pați naar deze kwestie liet instellen. Natuurlijk droeg dit een uiterst kiese vorm. In zijn schrijven aan de Hoge Regering informeerde de tumenggung beleefd naar de door de Palembangers op de Compagnie veroverde schepen en wel op het ogenblik, dat er van heel Palembang slechts een rokende puinhoop over was (D. 15 dec. 1659). Natuurlijk werkte zulk een brief niets meer uit; de zaak was afgedaan en de Compagnie antwoordde met een brutale en triomfantelijke bekendmaking. Dit moet de Vorst wel diep getroffen hebben. De Bantammers, gewoonlijk goed op de hoogte van de mentaliteit van hun buurman, zagen hem reeds als wreker zijner ontrechte vazallen.

Hoe ernstig hij zich inderdaad Palembang's ondergang aantrok, bewijst de mededeling, dat de sjabandar en de broeder van ng. MartaNata het te Palembang door de Nederlanders veroverde geschut voor de Sunan zouden gaan opeisen. Dit zal de Hoge Regering, die van de verhouding tussen Palembang en Mataram het fijne niet afwist, vreemd zijn voorgekomen (H.R. 4 apr. 1662).

Daarom heeft deze Palembangse kwestie de verhouding tussen Batavia en Mataram sterk bedorven, ja, heeft waarschijnlijk de doorslag gegeven tot een tijdelijke breuk, die zich uitte in een tweede havensluiting. 


\section{XI.}

\section{HET TWEEDE CONFLICT.}

De havens andermaal gesloten. 1660.

Volgens de generale missive dd. 16 dec. 1660 (d. J. VI, 87) had de Sunan in april van dat jaar ,alle vreemdelingen, Maleyers, Javanen, niemant uytgesondert uytgeset ende syn lant verboden... maer bovendien... Comps. logie tot Japara doen opbreecken ende afsmyten, doch alles evenwel met minne ende sonder eenigen schyn van quade genegentheyt...". Alles ging dus rustig en zonder opschudding in zijn werk. Volgens een later bericht, via Bantam opgevangen, moest de rijksbestuurder kj. Wira-Djaja de strandheren aanschrijven, dat „Zyn Mayt. voornemens was zyne havens voor . . 4 jaren te sluyten, ende dat zylieden zulks aen de vreemdelingen zouden bekent maken, largerende degene, die genegen mogten wesen te vertrecken" (D. 20 sept. 1661 p. 283).

De rol der strandheren bij deze havensluiting was dus vrij passief; de personen die daarentegen, gelijk bij de eerste sluiting, zich zeer actief betoonden, waren de tugurs van het Mataramse hof, „die in 't minste niet wilden gedogen, datter ijts uijt- of ingevoert wiert" (Rapport Michielsen). $\mathrm{Zij}$ waren over alle havensteden verspreid en ontvingen bevelen van het hof, dat hen in een oogwenk naar boven kon ontbieden. Daardoor ontstond de ijdele verwachting, dat de havens weer even spoedig open zouden gaan, als zij gesloten waren. Het valt ook op, dat destijds de strandheren meest aan het hof vertoefden. Vreesde de Vorst van hen overtreding of sabotage zijner bevelen? Hun werk aan de kust moest onderwijl natuurlijk door subalterne ambtenaren worden verricht (D. 24 juli 1661).

Dadelijk na de havensluiting was officieel verklaard, dat de havens gesloten waren, omdat de Sunan ,genegen was, nieuwe wetten over syn onderdanen te maeken", doch terecht merkten de Nederlanders op, dat dit "deselve praetjes" waren, „met dewelcke hy hem de vorige reyse... geholpen" had. Dit wantrouwen delende, zullen wij thans nagaan, welke andere oorzaken de Vorst tot zulk een ingrijpende maat- 
regel kunnen bewogen hebben. Vooreerst dient vastgesteld, dat het plan der havensluiting uit het binnenland, niet van de stranden kwam, ook al waren de strandheren er ook tijdelijk mee gebaat.

\section{De verantwoordelijkheid voor de havensluiting.}

Naderhand, toen het sluiten der havens de Sunan verdroot, schoof hij de verantwoordelijkheid daarvoor op zijn rijksbestuurder, $\mathrm{kj}$. WiraDjaja af, nadat ng. Marta-Nata hem verzekerd had, dat deze tg. Mataram ,zulks belast hadde" (D. 20 sept. 1661). Hiervoor werd deze rijksbestuurder openlijk bestraft.

Inderdaad moet zulk een de ganse kust bestrijkende maatregel ten slotte van het centrale bestuur zijn uitgegaan. Dit betuigt ook de latere gouverneur van Japara, kj. Wira-Dika in een brief aan G.G. Maetsuyker. Tot staving van zijn betoog, berinnerde hij er aan, dat het lichten der Japarase loge ,door het volck van Japare uyt last van de Sousouhounangh geordonneert" was; insgelijks de terugkeer der Hollanders. De gouverneur en zijn onderhorigen waren dus slechts uitvoerders der vorstelijke bevelen, die zij met de meeste gematigdheid uitvoerden.

Dat daarnaast sommige strandheren, zoals ng. Marta-Nata, bij de ontruiming der loge baat hadden, werd reeds betoogd. Weliswaar schaadde de havensluiting Japara's handel en dus ook zijn inkomsten, doch het weigeren van voorschotten en tolbetaling zal zijn neiging om ten hove het blijven der Nederlanders te bepleiten, sterk getemperd hebben, terwijl zij uitmuntend als zondebok konden dienst doen, waardoor de aandacht minder op zijn achterstallige schulden viel. Bovendien kwam ng. Marta-Nata's tegenstander, de als Compagnies vriend gedoodverfde tg. Pați, wiens positie door het Palembangse conflict al sterk geschokt was, door de breuk met Batavia in een nog moeilijker parket. Ng. Marta-Nata kan daarom in een havensluiting een welkom middel gezien hebben, om zijn mededinger te duperen. Daardoor zou hij vanzelf hoger stijgen, hetgeen inderdaad geschied is. De havensluiting heeft tg. Patị's val voorbereid. Aldus wordt het duidelijk, dat van een ernstig verzet der strandheren tegen deze krasse maatregel niets te merken is. Gedwee lieten ze hun havens op bevel der van boven gekomen tugurs toepaggeren.

Dat niet alleen de Nederlanders, maar ook alle andere vreemdelingen buiten de Mataramse havens werden gesloten, mag men gerust aan de tot het krankzinnige overhellende aard van deze wonderlijke Vorst toeschrijven. 


\section{Contactpogingen. 1660.}

De afsluiting van Java's stranden was zo volstrekt, dat men te Batavia ternauwernood enig nieuws uit het Mataramse rijk vernam. Daarom werd ten Kastele besloten boden op kondschap uit te zenden.

Op 11 juni 1660 stuurde de Hoge Regering de vaandrig $F$. H. Muller met tien Nederlanders en twintig Javanen naar Krawang om daar iets over doen en laten der Matarammers te vernemen. Daar men door deze zending niet veel wijzer werd, besloot men, ten einde berichten in te winnen en tevens de jongste Makassaarse victorie - die van 12 juni 1660 - in Mataram bekend te maken, Evert Michielsen, de gewezen resident van Japara, naar Sura-Baja te zenden. Daar zetelde immers de gewezen tg. Pați als gouverneur, „dat een vermogent heer in dat ryck ende d'E. Compe. altyts seer toegedaen geweest is" (Res. 29 juni 1660). Wellicht kon men er zo achter komen, wat er aan haperde en hoe de havens weer geopend konden worden. Men neme hierbij in aanmerking, dat genoemde Evert Michielsen bij de tumenggung van Sura-Baja even gezien was als door de gouverneur van Japara gehaat.

Hoe was intussen deze tg. Pati, thans tg. Sura-Baja, gevaren?

\section{De val van tg. Pati. 1659.}

Door de aanwezigheid van het Bataviaas Dagregister voor 1659 is het mogelijk tg. Patị's handelingen voor dat jaar nauwkeuriger na te gaan, dan daarvóór of daarná. Hij schijnt steeds ten hove te vertoeven, waarvoor als reden wordt opgegeven, dat hij zijn geld nog niet aan de Sunan had opgebracht (D. 15 mei 1659). Zijn verzoeken om geld te lenen van de Compagnie, waarover wij reeds schreven, werden steeds talrijker en dringender. Mogelijk was hij reeds op het einde van 1658 daarmede begonnen (D. 2 jan. 1659).

Bovendien viel hij de Hoge Regering telkenmale lastig om geschenken voor de Sunan, waarmede hij blijkbaar diens toorn hoopte te bezweren. Eerst een ,corge fijne, dichte cassa Bengalen ende 10 pees syde chavenys", dus Voor-Indische kleedjes (D. 28 febr. 1659). Dan, door bemiddeling van de Hollandse Javaan Michael Zeeburgh, die bij hem te Pati woonde, een Perzisch paard, ,van andere haer, als die voor dato geweest waren, nevens twee kamelen ende een paer kosdes, ${ }^{1}$ van gedaente als paerden". Kreeg hij een en ander, dan hoopte hij onge-

1 Wellicht een verschrijving van kuldi's, Javaans voor ezels, die inderdaad wa: van paarden weg hebben. Dr. P. Voorhoeve deed mij deze suggestie aan de hand. 
twijfeld zijn mededinger ng. Marta-Nata, die eind 1658 reeds een dergelijk verlanglijstje te Batavia had ingediend, voorbij te streven.

Daarna verzocht hij een ,cleen carosje met vier wielen, daer 4 à 5 menschen in conden sitten" (D. 7 juli 1659). Had hij zo iets tijdens zijn bezoek aan Batavia in 1653 gezien? Ruim twee maanden later kwam hij er op terug en vroeg dringend het karosje ,met den eersten" te bekomen. Zelfs oefende hij zekere politieke dwang uit: als hij het spoedig kreeg, zou hij de „redenen schryven, waerom de Compagnie met Palembangh in oorlogh was gekomen, opdat den Sousouhounangh niet door desselfs gesanten... geabuseert wert ende (zij) iets tot nadeel van de Compagnie mochten bewerken" (D. 21 sept. 1659 p. 196). Ook met dit verzoek dong hij mede met ng. Marta-Nata, die van de Compagnie Suratse osjes met (tweewielige?) karretjes had los gekregen (D. 15 mrt. 1659) en er groot succes mee geoogst had (D. 11 juli 1659).

Meermalen ondersteunde Michielsen de verzoeken van de tumenggung, soms node, soms van harte, omdat hij de inwilliging nuttig achtte. Het was zijn belang tg. Pați tegen ng. Marta-Nata te steunen, daar deze de Compagnie en hem zelf slecht gezind was. Zo bepleitte Michielsen het houtaanbod van tg. Pați (D. 15 mei 1659), drong er krachtig op aan, de geschenken voor de Sunan te zenden (D. 7 oct. 1659 p. 209), beval de geldverstrekking op te leveren suiker schriftelijk aan (D. 13 nov. 1659).

Niettegenstaande de noodkreten, die tg. Pați slaakte wegens levensgevaar, kans op degradatie en beroving, was hij in sept. 1659 mèt ng. Marta-Nata volgens laatstgenoemde nòg de machtigste ter kuste (D. 21 sept. 1659).

Doch naast andere heeft de Palembangse kwestie zijn positie ongetwijfeld ernstig geschokt. De verwoesting van de stad aan de Musi heeft de Sunan bijzonder geërgerd en verbitterd, hoe vriendelijk hij zich ogenschijnlijk ook over de Hollanders uitliet. Juist hieruit blijkt voor een kenner der Javaanse hofzeden zijn toorn. Vrienden der Compagnic, als tg. Pați, zullen in die ongenade gedeeld hebben. Om haar te treffen zal hij juist hem met een onderzoek naar Compagnies optreden tegen Palembang belast hebben, terwijl daarvoor toch eerder tg. Sura-Nata van Demak in aanmerking moest komen; bij deze berustte immers de zorg voor de Palembangse zaken. Dus zond de ongelukkige tg. Paṭi een drietal gezanten: Sindu-Watjana, Naja-Djiwa en Honko (een Chinees?) naar Batavia met het nederige verzoek om een pas, ten einde „te vernemen wegens de schepen ende goederen van myn broeder (de G.G.), die sy genomen hebben, met last om die aen myn broeder wederom te 
geven" (D. 15 dec. 1659). Een jaar eerder ware dit schrijven eerder van pas geweest; thans, na Palembang's vernietiging, was het mosterd na de maaltijd, en kon tg. Pați slechts een antwoord verwachten, in overeenstemming met de pas behaalde zege der Compagnie. $\mathrm{Zij}$ meende dat door deze overwinning „bij de omliggende vorsten de hoogen moet vrij wat zou sincken ende aen Compagnies wapenen een nieuwe ontsaghlijkheyt geven" (Afg. briefb. 1660 p. 37).

Dit pralen met het succes zal de Javanen, scherpe opmerkers der Europeanen als zij waren, zeker niet ontgaan zijn en daarom de goede verhouding geschaad hebben.

\section{Tg. Pați wordt tg. Sura-Baja. 1660.}

Omstreeks de jaarwisseling 1659-60 moet tg. Paṭi gouverneur over Sura-Baja geworden en daarheen vertrokken zijn. Tevens werd zijn broeder Nala-Tjitra in zijn plaats tot gouverneur van Djuwana (en Pați) benoemd. Beiden stelden de Hoge Regering door boden daarvan in kennis. Die van de nieuwe Sura-Bajase gouverneur heette TanuPradja, die van zijn broeder: Marta-Wangsa en Bangsa. Tevens nodigde eerstgenoemde de Compagnie uit een factorij aan de kali Mas te stichten, gelijk hij haar eertijds naar Pați had pogen te lokken.

Beider brieven werden op $24 \mathrm{mrt} .1660$ beantwoord (Afg. Briefb. p. 95 en 97). Behalve gelukwensen bevatten zij uitvoerige pleidooien voor Compagnies optreden tegenover Palembang. Uitgeweid werd over de snoodheid der Palembangers, die de rechtvaardige God had gestraft; over de omvang van de behaalde buit en dgl. meer. Ook werd de dood van de Palembangse pangéran gemeld, terwijl men er op aandrong, de Sunan in te lichten. Hoogstwaarschijnlijk zal men deze door dit relaas slechts geprikkeld hebben. De vrij snel daarop volgende havensluiting is als het onverwachte gevolg daarvan te beschouwen.

Tg. Patii's aanstelling over Sura-Baja zal men niet enkel als degradatie behoeven te zien. Het was een zeer belangrijke post, die slechts door een betrouwbaar persoon kon bekleed worden. Bovendien verving zijn broeder hem in Pați. Wel zat hij in het Oosten meer geïsoleerd, met name van zijn Hollandse vrienden, hetgeen zijn aanbod om in SuraBaja een factorij te stichten helpt verklaren. Ook zijn broeder was nu ver van hem verwijderd.

$\mathrm{Na}$ de havensluiting moet tg. Sura-Baja aan de Hoge Regering een niet bewaarde brief geschreven hebben, welks inhoud uit het Bataviase antwoord enigszins is op te maken. 
Hij zal er in geschreven hebben over het sluiten der havens, dat de komst van een Nederlands gezantschap ongedaan zou kunnen maken. Ook wees hij op de sterke band tussen Mataram en Palembang, dat als onderdanig aan de Sunan kon beschouwd worden. De strenge tuchtiging van die stad moet dus wel de grote grief geacht worden, die deze tot het sluiten der havens dreef.

Het antwoord der Hoge Regering was gedateerd 5 aug. 1660 (Afg. briefb. p. 470). Zij verklaarde pas tot een gezantschap te willen besluiten, nadat de havens reeds geruime tijd geopend zouden zijn. De laatste twee gezantschappen waren ook onbeantwoord gebleven en verdere afgezegd. Dit was beledigend voor de Gouverneur-Generaal en Raden, die „met de allergrootste koningen en potentaten alliantic en correspondentie mogen hebben". Daarna volgt een opsomming: Perzië, Hindustan, Wisjapur, Golconda, Arakan, Pegu, Siam, Tonkin, de grote monarch van Tartaria en China, de keizer van Japan enz.

„Wat alliantie ofte verbintenisse" tussen Mataram en Palembang bestond, was ten enenmale onbekend. In elk geval had de Sunan de moordenaars van drie jaar geleden nooit bestraft. Als de Vorst de Palembangers voor zijn "subjecten” hield, moest hij hun gelasten, de Nederlanders ,satisfactie" te geven.

In gelijke geest luidde de instructie aan Michielsen van dezelfde datum 'ibidem p. 364), die deze op zijn vertrek naar Sura-Baja werd ter hand gesteld.

\section{Evert Michielsen in Sura-Baja. 1660.}

Pas op 16 sept. 1660 bereikte Evert Michielsen, „worstelende met de groote tegenspoet", de rede van Sura-Baja. Te Japara hadden hem de tugurs of oppassers van het Mataramse hof de toegang ontzegd; er mocht niet het minste worden in- of uitgevoerd. Zelfs toen de plaatselijke gouverneur een brief aan de Hoge Regering schreef, moest hij „haer verblommen, dat niet naar Batavia, maer naer Sourabaija versond".

Op de rede dier stad liet Michielsen vijf schoten lossen ter bekendmaking van zijn komst. Daarop kwamen drie bevelhebbers van de tumenggung, zo mede Karti-Sarana (alias Tingsoy), een Chinees sjabandar, met vier prauwen de rivier af, om te zien, wie er was en wat men wenste. Pas twee dagen later brachten ze ten antwoord, dat „onse comst haren Heer seer aengenaem was". Als het hem niet door zijn groten belet was, die het aan de Sunan konden overbrieven, zou hij 
zelf in persoon gekomen zijn. Hij liet eerst kj. rg. Siḍaju, die in plaats van Wangsa-Radja strandheer was geworden, ontbieden, welke twee dagen later kwam. Gezamenlijk voer men de rivier op. Brief en geschenk der Hoge Regering werden aan tg. Sura-Baja overhandigd. Een „page” had twee dagen nodig voor het vertalen van de Maleise brief. Michielsen logeerde onderwijl in het hof en werd er goed onthaald. De tumenggung ontving hem beleefd.

Gesproken werd over de nederlaag der Makassaren, hetgeen de tumenggung en zijn groten wat vreemd in de oren klonk. Doch toen deze door Makassaren aan boord van het fluitje de „Postillon" bevestigd werd, kende zijn verbazing geen grenzen en moest hij toegeven, „datter geen natie ter werelt als de Hollanders waren"!

Veel nieuws had de tumenggung niet: kj. ng. Marta-Nata en WiraSetia waren omstreeks eind augustus naar boven ontboden, terwijl weinige dagen daarop ook de tugurs vertrokken waren, hetgeen gunstig leek. Over de opening der havens kon de tumenggung niets zeggen, maar naar de uitstaande schulden zou hij informeren. Ze werden in het Javaans opgeschreven.

Het zenden van een brief aan de Susuhunan had heel wat voeten in de aarde. Eerst wilde tg. Sura-Baja hem vooraf door de strandheren laten keuren, maar besloot ten slotte hem maar onmiddellijk aan de Vorst te sturen. Hij had er enige punten uit weggelaten, n.l. dat omtrent de ,legaten wedersijts naer de grote koningen van Persia, Hindoestan en dat de havens alvorens voor de gemeente wedersijts een ruijmen tijt g'opent moeste wesen", waarop de Hoge Regering zeer stond, eer zij weer een gezantschap naar Mataram zond. Tg. Sura-Baja wilde dit niet schrijven, ,uijt vrees sijn hooft te verliesen, want (zijn) Coning niet als ... anderen was, die oock daerby niet wilde vergeleken sijn". Men kwam ten slotte tot een allen bevredigende redactie. Over Palembang was weinig gesproken en werd dus weinig geschreven.

Toen het antwoord van tg. Pați aan de Hoge Regering gereed was op 25 sept. 1660, bleef Michielsen tot na middernacht bij zijn gastheer praten. Hij vond hem zeer ,variabel”. $\mathrm{Nu}$ eens verklaarde hij, dat de havens nog vier jaren gesloten zouden blijven, dan weer, dat ze om het schaarse gewas niet open mochten.

Ook deelde hij Michielsen mede, vernomen te hebben, dat or te Batavia een mooi hoog paard, in 1655 geboren, voorhanden was, ,root van couleur, 5 voet en 8 duijm, ja noch hoger"; ook was er een muilezel te krijgen. Dat zou misschien een middel wezen, om de havens te openen. 
Michielsen ging niet in op deze bedekte aandrang op een gezantschap. Hij antwoordde, dat het in het behagen van de Sunan stond, zijn havens te openen of te sluiten, „sijnde souvereijn heer". Zijn enige bedoeling was slechts Compagnies gereed liggende waren en uitstaande schulden op te halen. Daar alles contant betaald was, kon het wel niet geweigerd worden.

Tg. Sura-Baja begon toen weer over de brief aan de Sunan. Over twee maanden beloofde hij via Krawang, dus te land, antwoord te zullen zenden. Met veel beleid zou hij de zaak aanvatten. Werd de zaak niet goed opgenomen, dan zou hij er mee wachten tot zijn komst in de hofstad tegen Garebeg Mulud (op 15 nov. 1660).

Daarop volgde het afscheid met geschenken aan tg. Sura-Baja en zijn vier vrouwen. Michielsen kon er niet van af, want dagelijks was hij bedacht met fruit en gekookte spijzen.

Hij vertrok, niet wetende, dat hij de trouwe vriend der Compagnie voor het laatst ontmoet had.

\section{De dood uan tg. Sura-Baja. dec. 1660.}

De berichten over de dood van tg. Sura-Baja, eertijds tg. Pați, komen alle uit West-Java, zodat zij wat de bijzonderheden betreft, mogelijk onbetrouwbaar zijn. Aan de hoofdzaken valt echter moeilijk te twijfelen.

Op 20 mrt. 1661 schreef de Bantamse resident David Luton van kj. Aria vernomen te hebben, „dat den Sousouhounang Mattaram den Tommagon Sourabaya, voor desen ... Tommagon Paty ... omtrent drie maanden geleden hadde doen dooden" (D. 22 mrt. 1661). Enige dagen later werd dit bericht vanuit Tjerebon bevestigd (D. 29 mrt. 1661), en nogmaals vanuit Bantam (D. 16 apr. 1661). Het drama zou dus in dec. 1660 hebben plaats gevonden, nadat hij omstreeks half nov. 1660 de Kraton bezocht had.

Mèt hem was zijn hele familie vermoord, uitgezonderd de oudste zoon (d. J. VI, 90). Ook hoorde men, dat „het doode lichaem van tommagon Patty niet begraven, maer in see geworpen was" (D. 11 mei 1661).

De Babad Sengkala bevestigt deze moord op tg. Sura-Baja, die zij bij zijn eigen naam Nata-Ernawa noemt, en geeft als plaats van de misdaad merkwaardigerwijze Ngadilangu en voor het jaar A.J. 1583 (begin: 6 sept. 1660). Is hij soms op de terugreis van de Kraton om het leven gebracht?

Voor deze gewelddaad worden verschillende redenen opgegeven. 
De aannemelijkste is wel, „dat hy tommagon den koopman Evert Michielsz ... hadde toegelaten ..., daer hij wel wist, dat zyne Mayt. de havens alomme zoo vast hadde laten sluyten" (D. 4 apr. 1661). Zijn vriendschap voor de Compagnie had hem dus het leven gekost. Hiermede klopt de verklaring van de Sunan zelf tegen het eind van 1662: tg. Sura-Baja zou hem „omtrent de Hollanders met syn bedelen tot cleenachting gebracht" hebben (D. 1 jan. 1663). Hij had dus tegenover de Nederlanders onvoldoende ruggegraat getoond.

Geheel anders is het verwarde bericht in D. 18 juli 1661, waarin het gerucht voorkomt, dat de Sunan met een zuster van zijn schoonvader pg. Pekik, dus zijn tante, zou getrouwd geweest zijn; dat daarna die vrouw de echtgenote van tg. Sura-Baja zou zijn geworden. Deze had haar op vorstelijk bevel moeten doden, hetgeen hij enkele malen had geweigerd. Ten slotte had hij haar gekrist, wat hem weinig gebaat had. Hij was toch gedood. Mocht dit verhaal aanvechtbaar zijn, zo is het toch van belang voor de wijze, waarop de spraakmakende gemeente zich haar Vorst voorstelde.

De val van tg. Sura-Nata van Demak. 1661.

Kort na de dood van tg. Sura-Baja, verdween ook zijn vriend, de tumenggung van Demak van het staatstoneel.

Deze, tg. Sura-Nata geheten - men vindt ook wel Suria-Nata treedt laat, en dan nog weinig op de voorgrond. Het eerst wordt zijn naam als heerser over Demak in 1654 genoemd, doch vermoedelijk is hij daar al eerder aan het bewind, omdat hij in 1652 in één adem met tg. Pati genoemd wordt (v. Goens 121).

$\mathrm{Hij}$ behoorde tot het viertal, dat, tijdgenoot van de Sunan, deze van jongs af aan gediend had (v. Goens 249). Bij zijn aftreden eindigde ook een tijdvak, daar men in 1664 nog sprak over, ,ten tyde van den tammagon Damak” (D. 2 juni 1664). Hij zal dus geen waardige vervanger hebben gehad.

Reeds in 1661 bleek zijn positie niet meer zo sterk te wezen en heette hij al omgebracht te zijn (D. 4 apr. 1661). Later betwijfelde men zijn dood (D. 16 apr. 1661); hij bleek slechts ontslagen te zijn en vervangen door „radin Hadamakkan” (t.r.: Ka-demak-an) (D. 25 nov. 1661). Hij was van Demak gedeporteerd en van al zijn bezittingen beroofd. Er werd gemeld: „Hy blyft in de Mataram en heeft een van des Konings kinderen onder zyn opvoeding. Maer alsoo hy de zwager is van den tommagon Patty, meent men, dat hy denzelven gang zal gaen". 
Na de degradatie van de Demakker was ng. Marta-Nata als gouverneur van Japara de enige der vier strandheren, die nog op zijn post gelaten was.

Glorie van ng. Marta-Nata. 1659-61.

Tegen het einde van 1659, toen tg. Pați's ster verbleekte, bereikte de invloed van ng. Marta-Nata een hoogtepunt. Zo zeer genoot hij de vorstelijke gunst, dat men voor zijn positie vreesde (D. 13 nov. 1659). Vast is deze niet, daar een gerucht zijn vermoording meldt (D. 4 apr. 1661), waarover men te Batavia geen „recht bescheyt" had (D. 16 apr. 1661). Maar een maand later had hij als ,gewesen gouverneur van Japara rechtevoort syn residentie in 't hof', hetgeen een promotie kan betekenen. De gewezen gouverneur van Kenḍal, Wira-Setia, een ,zeer groot vrund der Hollanders", nam zijn taak te Japara waar (D. 11 mei 1661). Deze durfde ten hove ook de terugkeer der Nederlanders naar hun loge bepleiten (D. 20 sept. 1661). Ng. Marta-Nata, hoewel geen vriend der Compagnie, kan het nut dezer terugkeer hebben ingezien. Maar ook voor anderen wilde hij Japara weer open stellen, zodat hij de gewezen tolk der Engelsen, Thomas Armagon beval, de vervallen Engelse loge te herstellen. 1

De verzoeningspolitiek schaadde zijn aanzien bij de Sunan niet. Hij stond bij deze ,in grooten aensien en (werd) boven alle andere met vele Javaense eertytelen en met een gouden pinangbekken begunstigt"; ja men meende, dat hij de tweede Wira-Guna zou worden (D. 25 nov. 1661). Deze vergelijking was niet zonder reden. Immers, gelijk tg. WiraGuna eertijds de enige van een viermanschap was, dat het ambt varı tg. Mataram waarnam, die ten slotte op de voorgrond trad, zo was eind $1661 \mathrm{ng}$. Marta-Nata de enige der vroegere vier strandheren, welke nog de gunst van de Sunan genoot: zijn vriend en ambtgenoot ng. WangsaRadja bracht hij in 1659 zelf ter dood; tg. Pați werd het volgende jaar naar Sura-Baja verplaatst en in 1661 gedood, terwijl in dat zelfde jaar ook tg. Sura-Nata uit zijn ambt werd ontzet.

Hoe ver zijn invloed strekte bewijst zijn bemoeienis met West-Java.

1 Zeker niet toevallig is het, dat destijds ook de Engelsen het herstel hunner relaties met Japara overwogen. Brief van de president van Madras dd. 20 nov. 1661 aan de agent in Bantam over een mogelijke plaatsing van een mr. Rob. Dearing in Japara of Makassar (W. Foster, The English Factories in India $1661-64$. Oxford 1923 p. 51). 
De kolonisatie in West-Java. 1660-61.

Raadselachtig lijkt n.l. op het ecrste gezicht de kleine actie, die de Javanen bij Muara Bérés ondernomen hebben. Vermoedelijk is deze niet veel meer geweest, dan wat de vaandrig Frederik Muller van 17 tot 20 sept. 1661 op zijn verkenningstocht naar het binnenland ontdekte.

Gealarmeerd door Bantamse geruchten en een bericht van de luitenant der Javanen, was genoemde vaandrig met 10 soldaten en een 50 Javanen de rivier Bekasi opgevaren, tot hij bij een plek gekomen was, waar Javanen een "negerye ofte dorp” begonnen te maken (D. 17 sept. 1661). Twee „orangcays” en nog 8 man had hij naar Batavia gebracht. De hoofden droegen de echt Javaanse namen van Suta-Truna en Wira-Suta (D. 20 sept. 1661). Ondervraagd deelden zij mede, dat zij uit 't Schilintsick (Tjilintjing?) kwamen. Een jaar te voren, dus in 1660, waren zij door de ,gouverneur van Japara" met omstreeks honderd man daarheen gezonden om een ,nieuwe negerye” te stichten, „het land te bebouwen en rys te planten, ook hout en bamboesen te kappen". Door haar ligging aan de Bekasi-rivier was die plaats zeer geschikt, om deze zaken naar Batavia te brengen en aan de Compagnie te verhandelen. Sedert waren zij niet weer in hun vroegere desa teruggekeerd, maar het hoofd daarvan was hen twee maal komen bezoeken, zonder iets anders te zeggen dan: „Dit is een fraeye plaets”.

Op deze kolonisatie doelt ongetwijfeld ook het in Bantam lopende gerucht omtrent een actie van de Matarammer te Muara Bérés. De Sunan zou er 500 man heen gezonden hebben, om „rys te versamelen”, doch er moesten nog 80.000 volgen (D. 29 juni 1661). Men was in Bantam daarom op zijn hoede en legerde 4000 man te Wates, 4 uur be-oosten Muara Bérés. Tegenover de Bantammers verontschuldigden de kolonisten zich: de Sunan wilde de Hollanders beoorlogen. De Bantammer bleef echter op zijn hoede en zond twee verspieders, aan wie bij goed resultaat een vrouw en 25 rds. beloofd werden. Ook naar de oostelijke havens werden zes vaartuigen ter verkenning gestuurd (D. 16 aug. 1661). Steun aan Landak werd geweigerd, omdat de Sunan een grote macht van volk naar Muara Bérés zou gezonden hebben. Op den duur vervluchtigden deze geruchten tot niets.

Wat kan de bedoeling dezer schijnbaar zo onschuldige actie geweest zijn? Zeer waarschijnlijk was zij niet tegen Bantam gericht, evenmin rechtstreeks tegen Batavia, doch zij heeft blijkbaar de bedoeling gehad op slinkse wijze des Sunans aanspraken op gebied ten westen van de 
Tji Tarum te laten gelden, zonder daarbij ernstig gevaar te lopen. Immers, wat wist men in het Kasteel van de Sundalanden af? Pas na een jaar werden de kolonisten vanuit Batavia opgemerkt. Men kon zich daarom in Mataram verbeelden, dat de Susuhunan in Priangan dorst op te treden.

Als beramer van dit plan noemden de hoofden der kolonisten de gouverneur van Japara, dus niemand minder dan ng. Marta-Nata, wiens ster toen juist in het zenith stond. Deze West-Javaanse actie is ook in overeenstemming met 's mans jacht op schijnsuccessen aan het hof. Zulke resultaten waren onmisbaar om 's Vorsten gunst te blijven genieten. Tevens toont deze actie, aan, hoe ver de invloed van de Japarase gouverneur buiten zijn eigenlijke ambtsgebied strekte.

Hoe handig hij aan dreigende gevaren wist te ontsnappen, blijkt uit zijn conflict met de tg. Mataram, Wira-Djaja. Volgens de Afgaande Missive van 4 nov. 1662 (p. 592) zou hij beschuldigd zijn van een poging, om deze te vergiftigen, samen met de „bastaardzoon" van de Sunan, op wie wij in een volgend deel terugkomen. Hij zou deswege slechts tot een boete van 8000 realen veroordeeld zijn, maar had deze kunnen betalen, ofschoon hij ze in de benedenlanden van alle kanten bijeen had moeten schrapen. De Hoge Regering achtte het daarom een gelukkige omstandigheid, dat de resident toen juist weinig geld in huis had gehad. Deze boete had zijn positie hersteld. Natuurlijk heeft hieraan méér vast gezeten, dan hier kort werd medegedeeld.

$\mathrm{Na}$ aan vele gevaren ontkomen te zijn, struikelde ng. Marta-Nata ten slotte over een kleinigheid: zijn paardenaankopen te Batavia. Toen het hem, gelijk wij zien zullen, niet gelukte de Compagnie tot een nieuw gezantschap te bewegen, meende hij ten minste de Sunan van Perzische paarden te moeten voorzien, die z.g. uit haar naam kwamen. Dit werd zijn val.

Ng. Marta-Nata laat paarden kopen. 1662.

Wij zagen reeds, dat zelfs in Sura-Baja de inhoud van 's Compagnies paardenstal niet onbekend bleef. In Japara zal dit ook het geval geweest zijn. De gouverneur van deze plaats haalde zich een bijzondere moeilijkheid op de hals door de aankoop van paarden in Batavia. Blijkbaar wilde hij tonen alleen in staat te zijn tot hetgeen eertijds de vier strandheren gezamenlijk presteerden.

Volgens een later bericht zou de Sunan hem slechts gelast hebben vaartuigen naar Batavia te zenden, om te zien wat voor paarden er 
te koop waren, van welke kleur en grootte. Daarvan moest hij de Vorst verslag doen, maar niet kopen (D. 15 apr. 1663). Dit klinkt aannemelijk, doch de gelijktijdige berichten melden, dat hij meer gedaan heeft.

Vóór 9 juni 1662 (Afg. Briefb. p. 144) schijnt hij reeds geïnformeerd te hebben, hoeveel paarden in de stal van het Kasteel bewaard werden. Het antwoord luidde: twee. Daarop kondigde hij een gezant aan (ibidem dd. 1 juli 1662 p. 227). De Hoge Regering nam zich voor, deze behoorlijk te onthalen. Vervolgens werden in Batavia (Javaanse) paarden en twee grote ossen ontvangen, maar nog geen bode (ibidem dd. 3 aug 1662 p. 327). De briefdragers zouden echter op 22 juli uit Japara vertrekken. Vóór 8 sept. 1662 (ibidem p. 436) verschenen dezen in Batavia, t.w. kențol Puspa-Raga van ng. Marta-Nata, en lurah Patra van Wira-Setia, gouverneur van Samarang. Hun geschenken waren: zes last rijst, drie paarden, waarvan één dood, en vier grote ossen. Zij zeiden uit naam van de Sunan te komen, om twee Perzische paarden en kleden te kopen. De brieven waarbij de door hen uitgezochte paarden aan de Vorst werden aangeboden, dragen de datum 28 sept. 1662 (ibidem p. 540). De Hoge Regering verklaarde daarin zich over de vorstelijke gunst, welke ng. Marta-Nata genoot, te verheugen. De inning harer vorderingen bleef hem hartelijk aanbevolen. In een schrijven aan haar resident (ibidem p. 557) werd ten slotte verhaald, dat de Javaanse gezanten op 29 sept. 1662 met eigen vaartuigen uit Batavia vertrokken waren, wel vergenoegd en elk met een Perzisch paard.

Maar kort daarop was over die twee paarden ten hove ,al eenige hapering" geweest. De Sunan had hun gevraagd, „of en voor hoeveel sy die gecocht hadden". Tot antwoord krijgend, dat H.Ed. hun die geschonken hadden, vroeg hij wederom, of zij dan soms gezanten of brieven daartoe naar Batavia gezonden hadden. $\mathrm{Zij}$ ontkenden dit, doch verzekerden, dat ,haere gecommitteerden, die sy volgens ordre van zyne Mayt. nae Batavia gesonden hadden, deselve paerden hadden medegebracht". De Sunan vroeg hun nogmaals, hoe het mogelijk was, dat de „Generael van Batavia sulcks uyt sich selven dede, sonder versocht te syn". Hierop antwoordde ng. Marta-Nata, „dat de factoor van Japara ..., verstaen hebbende, dat de peerden van syn Mayt. seer oud begonden te worden, en dat syn Mayt. wel begeerig was, om een jonger te hebben, den Capitain Moor sulcks hadde( $n$ ) bekent gemaeckt, ende dat daerop de peerden met een schip van Batavia gesonden waeren".

$\mathrm{Na}$ dit antwoord zweeg de Sunan enige ogenblikken en zeide einde- 
lijk: „Uw peerde, Marta-Nata, is my aengenaem, maer ick en verstae niet, dat ghy eenige van uwe dienaren nae Batavia sult senden om yets van den Capitain Moor voor my te begeeren; oock niet aen den factoor op Japara, want om die oorsaeck heb ick den tommagon Surbaya (tg. Pați) laaten dooden, die my omtrent de Hollanders met syn bedelen tot cleenachting gebracht heeft; ghy beyde moet $\mathrm{u}$ wel wachten, dat ghy uyt mynen name van geen andere natie oock iets begeerd".

Naderhand kwam uit de Kraton bericht, dat de paarden weder ten huize van ng. Marta-Nata gebracht waren, met bevel ze naar Batavia terug te zenden. Dit is evenwel niet geschied. Kj. Wira-Setia, die het andere paard geschonken had, zou later afgezet zijn (D. 1 jan. 1663). Ng. Marta-Nata kwam er voorlopig gemakkelijker af, daar de Sunan hem nog voor een gewichtige opdracht bewaarde: een zending naar Tjerebon.

\section{Ng. Marta-Nata wijzigt het Tjerebonse bestuur. Eind 1662.}

Vermoedelijk bevond de vorst van Tjerebon zich sedert 1648 aan het Mataramse hof (Priangan III, par. 62). Wij zagen reeds, dat de Sunan hem gebruikte, om zich van Bantam's hulde te verzekeren, terwijl ook een huwelijk tussen zijn dochter en de kroonprins beraamd werd. Geen dezer plannen slaagde.

Begin 1661 deden sombere geruchten omtrent deze ratu de ronde: de Sunan zou hem hebben laten doden (D. 22 mrt., 4 apr., 16 apr. 1661). Ten slotte blijkt, dat de „pangoran Cherebon nu 't eenemael van alle syne middelen, slaven ende slavinnen berooft ... sich als een gemeen man onthielt in het dorp Pajaten" (D. 11 mei 1661).

Mag men deze berichten omtrent de Tjerebonse vorst in verband brengen met het Bantamse nieuws, ,dat eenige grooten... van het maegschap van pangoran Cerebon gebonden wierden, om 's anderen daegs nae den Mataram gebragt te worden"? Men twijfelde er niet aan, of de pangéran was reeds omgebracht. Dit laatste was nu wel niet het geval, doch zeker had in het Tjerebonse onrust geheerst, wellicht in verband met de havensluiting.

Volgens Hageman overleed de Tjerebonner in 1662, terwijl de Babad Tjerebon als zijn sterfjaar A.J. 1585 opgeeft (begin: 16 aug. 1662). Ng. Marta-Nata's reis naar Tjerebon zal wel in verband met dit overlijden hebben gestaan. Tussen 21 nov. en 4 dec. 1662 vertrok hij, om de ,wet aldaer te versetten", dus: de regering te veranderen (D. 1 jan. 1663). De ratu zal dus omstreeks october 1662 gestorven zijn. 
Hij werd eervol op de begraafplaats Giri-Laja ter aarde besteld, zodat hij wel niet zal vermoord zijn. Aan deze rustplaats dankt hij zijn postume naam: panembahan Giri-Laja. Slachtoffers van Tegal-Wangi werden gemeenlijk elders begraven, n.l. in Banju Sumurup.

De dood van ng. Marta-Nata. dec. 1662.

Nadat ng. Marta-Nata op 19 dec. 1662 te Samarang was teruggekeerd, werd hij drie dagen later met zijn twee zonen naar Mataram ontboden en daar dadelijk door niet minder dan 4000 man bewaakt. Men bedenke, dat de gouverneur van Japara volgens gebruik met groot gevolg naar de hofstad zal zijn opgereisd, zodat een kleine bewaking geen doel zou treffen. De volgende dag werd hij bij de Sunan ontboden.

Eerst vroeg de Vorst, hoeveel vaartuigen gereed lagen, daarna, hoeveel hij voor het Perzische paard betaald had. Op Marta-Nata's antwoord: 300 rds., ontstak hij in toorn en zeide: „Ghy liegt het, Marta-Nata, en ook dat de Hollanders het hier gebracht hebben; ' $t$ is wel waer, dat ick $U$ belast hebbe, dat ghy vaertuygen na Batavia soud senden, om te sien, wat peerden datter waeren, van wat groote en coleur, en dat ghy my daervan bericht soud geven; dàt is $U$ belast, en niet, dat ghy soud kopen".

Marta-Nata „bad seer beweeglyck om vergiffenis, maer de Sousouhounang, hem niet hoorende, stond op, en belaste den stadhouder Wiera Dejaja (tg. Mataram), dat hy Martanata met een kris het hoofd soude afsnyden". Dit is ongebruikelijk; men steekt met een kris.

„De grooten waeren terstondt bereyt, vattende hem dryvende op, brachten hem op het pleyn (pagelaran?) en sloegen (sic) hem met malkander de kop af, maer mosten hem wel 30 slagen met haare krissen geven, eer se gedaen" hadden (D. 15 apr. 1663).

Deze gruwzame terechtstelling maakte in en buiten Java een diepe indruk. $\mathrm{Zij}$ gaf de Pangéran van Palembang ,al wat naedencken, om niemand van de grooten derwaerts te senden" (D. 14 mei 1663). Beduidt de vermelding van de tg. Mataram als uitvoerder van het wrede bevel een zege van het binnenland op de kuststreek? Het aan ng. Marta-Nata teruggezonden paard werd na diens dood in zijn nalatenschap aangetroffen; de Sunan nam het weer tot zich.

Behalve uit Nederlandse bron kennen wij Marta-Nata's einde nog uit de Babad Sengkala, die onder A.J. 1585 (begin: 16 aug. 1662) vermeldt: demang Marta-Nata pedjah pagelaran mantuné, dus: demang Marta-Nata stierf op de pagelaran van zijn schoonzoon. Was 
de Sunan met een zijner dochters getrouwd, zoals bij meer gunstelingen het geval was? 1

Marta-Nata's relaties met de Compagnie hadden zowel tot zijn kortstondig succes als tot zijn verschrikkelijke dood geleid. Hoe gedroegen de Nederlanders zich tegenover de Mataram sedert de wederopening der havens?

$1 \mathrm{Ng}$. Marta-Nata heeft zich sedert zijn belangen en werkzaamheden meer in het binnenland kwamen te liggen, aan de kust van een medewerker en helper bediend, kj. Wira-Setia. Deze was reeds van 1648-51 gouverneur van Japara geweest ( $v$. Goens 48, 49, 68-70), viel daarna in ongenade en werd naar het minder belangrijke Kenḍal overgeplaatst (v. Goens 79).

Doch in 1661 treedt hij, nadat reeds vele groten van de kust verdwenen zijn en ng. Marta-Nata ,rechtevoort syn residentie in 't hof hadde" (D. $11 \mathrm{mei}$ 1661) als ,gewesen gouverneur van Candael" meer op de voorgrond. Hij vervangt Marta-Nata in Japara, wat in de smaak der Nederlanders valt, daar hij ,voor desen altyd een zeer groot vrund van de Hollanders is geweest". Ten hove schijnt hij tijdens de $2 \mathrm{e}$ havensluiting een bemiddelaarsrol te spelen (D. 20 sept. 1661). Wellicht gebruikte ng. Marta-Nata hem om opnieuw met de Compagnie contact te krijgen. Tegen het einde van het jaar wordi hij gouverneur van Pați, doch slechts over dit gebied, niet tevens over alle stranden, zoals beweerd werd (D. 25 nov. 1661). Het volgende jaar doet hij mee aan ng. Marta-Nata's beruchte paardenaankoop te Batavia. Nog vóór ng. Marta-Nata's dood blijkt hij reeds te zijn afgezet, wat geen gunstig teken is (D. 1 jan. 1663 p. 3), heerst in 1664 over Lasem en Kenḍal (D. 14 apr. 1664). Latere berichten wekken de indruk dat hij weer over Japara te zeggen heeft. (D. 20 apr. 1664, 17 mei 1664). Zijn dood kan dan niet meer ver af geweest zijn, daar hij reeds in 1648 oud heet. 
XII.

\section{HET HERSTEL DER LOGE.}

Het weder openen der havens. 1661.

Op 24 juli 1661 (D.) kwam te Batavia een zekere Patra van Demak met een konting, gezonden door de sjabandar aldaar, meldende, dat de Sunan van Mataram bevolen had, zijn lang gesloten havens te heropenen. De strandheren waren nog boven, doch werden dagelijks terug verwacht.

De Hoge Regering achtte dit bericht belangrijk genoeg, om het in een korte extra missive van 29 juli 1661 naar patria door te zenden (d. J. VI, 89 noot).

Was het tot de Vorst doorgedrongen, dat de havensluiting zijn onderdanen minstens zo erg schaadde als de Compagnie? Of hadden de ten hove vertoevende strandheren - ng. Marta-Nata incluis hem tot andere gedachten weten te brengen? Misschien dat een brokstuk van zulk een gedachtenwisseling via Bantam in het Bataviaas Dagregister is terecht gekomen (D. 20 sept. 1661). De Sunan had n.l. aan zijn groten gevraagd, "of Batavia om geen leeftocht benodicht" was. Hij vroeg dus naar het resultaat der havensluiting. Daarop had de vroegere gouverneur van Kenḍal, Wira-Setia geantwoord, „van zyn dienaers verstaen te hebben, dat den rys tot Batavia noch wel voor 50 realen was te krygen, ende dat hy niet en twyffelde, of de Hollanders zouden nu, met het heropenen van zyne havens wederom op Japara komen resideren". Ogenschijnlijk bereidde deze strandheer een verzoening voor, waarbij hij ook zijde hoopte te spinnen.

De rest van het Bantamse bericht is er op uit, het gezicht van de Sunan te redden. De volstrekte havensluiting zou n.l. op een misverstand berusten. De Vorst zou tot zijn verbazing vernomen hebben, dat alle vreemdelingen uit zijn rijk verdreven waren. Daarop had hij aan de gouverneur van Japara gevraagd, ,wie hem daertoe zoo stout gemaekt hadde?" Toen geantwoord was, dat kj. Wira-Djaja dit gelast had, liet de Sunan deze tg. Mataram terstond ,buyten op de basar ofte marktvelt voor zyn hof brengen, aldaer aen een pael binden ende... 
alsoo twee dagen lang in de zon staen braden". Gezien de toenmalige Kratongebruiken en des Sunans wraakzuchtig karakter kan deze voorstelling op waarheid berusten.

De terugkeer der Nederlanders in Japara. 1661-63.

Gelijk de Nederlanders hun loge op bevel van de Vorst hadden moeten ontruimen, zo zouden zij daar nu op zijn last dienen terug te keren. De Sunan had n.l. zijn strandheren gelast te vernemen of „de Hollanders niet genegen en waren wederom ... op Japara te mogen resideren, dan of d' Heer Generael met hem in oorlog wilde komen, en dat zy het hem dan terstond zouden laten weten" (D. 20 sept. 1661). Op korte termijn moesten de Nederlanders dus hun loge weer betrekken, of anders: oorlog!

Het zou nog bijna twee jaren duren, eer de resident weer zijn oude, verwaarloosde loge betrok. Men wist nog niet, welke koers de Javanen t.o.v. de Compagnie zouden volgen na de tweede mislukking der havensluiting.

Bij de opening der havens werd de boekhouder David Luton, die jaren te Bantam gelegen had, naar Japara gezonden (d. J. VI, 90). Zijn opdracht luidde te vernemen, hoe het daar stond, of men de loge kon betrekken, houtwerken en andere zaken terug krijgen. In dat gunstige geval mocht hij zelfs een gezantschap in het vooruitzicht stellen. Ook rijst diende bemachtigd te worden. Eind dec. 1661 zou hij Bantam verlaten (D. 31 dec. 1661).

De eerste maanden heeft Luton een schip ter rede van Japara bewoond, zoals gebruikelijk was in plaatsen, waar men zich niet aan de vaste wal waagde, „wegens de vreemde grillen der ongestadige menschen" (H.R. aan Luton dd. 4 apr. 1662). Pas als de loge op kosten der Javanen hersteld was, mocht hij aan wal gaan; kleden en contanten dienden echter aan boord te blijven.

Tegen het einde van $1662 \mathrm{kreeg}$ de resident door bemiddeling van de gouverneur ng. Marta-Nata te beschikken over de nalatenschap van één van Compagnies schuldenaars, de vermoorde Chinees Sanco (H.R. aan Luton dd. 28 oct. 1662). Hierbij bevonden zich twee stenen huizen ter waarde van 150 realen. Luton nam daarin nu zijn intrek, ook al verkoos hij een verblijf aan boord, ,alsoo men niet weten en kan, wat de Javanen noch in 't sin hebben". De loge wilde hij pas op des Sunans bevel gaan bewonen, doch dit was nog niet afgekomen. Wel 
verklaarde ng. Marta-Nata, dat niemand hem dit zou beletten, en dat hij hem daar ook liever zag, omdat „de Sousouhounangh wellicht op hem gram soude werden, indien ... Zyn Mayt. hoorde, dat deselve logie, die nu seer bouvallig wierd ... instorte, sonder dat men de hand daeraen gehouden had"' (D. 1 jan. 1663).

Terecht was de resident voorzichtig. Immers, toen hij na een tocht naar Rembang op $31 \mathrm{dec} 1662$ terugkeerde, vond hij de boekhouder Pieter Brinckhoff druk bezig met het inschepen van Compagnies middelen. De reden was, dat de nieuwe gouverneur Tanu-Menggala dit gewild had, met bevel, "dat niemand en soude uytvaren, jae in zee kyken; begeerende oock niet, dat d' onse aen land souden woonen". Geen der groten had n.l. tot nog toe de vestiging der Nederlanders aan de wal aan de Sunan bekend gemaakt (D. 15 apr. 1663 p. 153). Toen Luton er evenwel op aandrong, vond de gouverneur goed, dat zij tot nader order van de tg. Mataram, kj. Wira-Djaja, an wie hij erover had geschreven, aan land mochten blijven.

Vier maanden verliepen rustig. Toen zou de Sunan aan de tg. Mataram gevraagd hebben, ,wat handeling de Hollanders op Japara deden". Het antwoord luidde: rijst, hout enz. Verder wilde de Vorst weten, hoe sterk zij daar waren. „Tien man”, zei de tumenggung. Ook informeerde de Sunan, of de Hollanders nooit iets verzocht hadden. Het antwoord luidde ontkennend. Hierop zou de Mataramse vorst gezegd hebben: „Gaet, en zendt nae Japare, en belast de Hollanders, dat se terstondt weder in haer oude logie keeren, met aensegging, dat se weltevreden moeten syn en dat myn geheele land voor hen open staet, waerin sy vryelyk haeren handel mogen dryven; maer segt haer, dat sy geen stukken in haere logie moeten setten" (D. 5 sept. 1663). Dit bevel werd opgevolgd.

Op 17 aug. 1663 verscheen Karti-Djaja, ,regent van Japara” (dus niet de gouverneur), door de Sunan ,expresselyck en schielyck uyt den Mataram afgesonden" (D. 23 aug. 1663). Zodra deze 's morgens met zijn vaartuig bij de boom aanlegde, vroeg hij de boomwachters, of de resident thuis was. Deze was juist de vorige dag uit Rembang teruggekeerd. Hierop stapte Karti-Djaja aan wal en begaf zich naar de paseban (hier wel: aloen-aloen). Daar liet hij de resident door de sjabandar roepen. Deze verscheen bij Luton "met een geweldig gedruys van menschen". Samen met de boekhouder ging de resident naar de paseban. Toen Karti-Djaja Luton zag aankomen, begaf hij zich naar het gouverneurshuis, waar hij ging zitten. Luton volgde hem en nam ook plaats. Daarop liet Karti-Djaja alle groten van Japara voor zich komen. 
Hij gaf hun te kennen, dat de Susuhunan Mataram, wetende, dat de resident zich zo lang beholpen had, hem Karti-Djaja had uitgezonden, om de resident weer als voorheen de Compagnies loge te doen bewonen; de Vorst gelastte, dat dit bevel ,,sonder het alderminste vertoeven moste naegekomen worden, alsoo syn Hoogheyt niet langer en begeerde te gedoogen, dat de resident in een Chinees huys bleef woonen". Toen vroeg Karti-Djaja, of hij dit wilde aannemen. Luton antwoordde van ja, daar zó het bevel van de Sunan luidde, voor welke gunst hij hogelijk bedankte. Daarop volgde een lang stilzwijgen, dat de resident onderbrak om een weinig respijt te vragen, ten einde de loge in orde te brengen en te ompaggeren. Hij kreeg echter van Karti-Djaja het bitse antwoord: „'t En mogt niet geschieden; men mogt des Sousouhounangs gunst soo niet verwerpen”. Verder verklaarde hij: „Ook al was er geen pagger om de loge, wat gaf dat? Het ongeluk, dat de resident zou treffen, zou hun koppen kosten". Hierbij wees hij op alle groten in Japara. Luton behoefde dus niet bevreesd te zijn.

Nogmaals liet de resident de Sunan bedanken en beloofde dadelijk uit het Chinese kwartier naar de loge te verhuizen.

Voorts gaf Karti-Djaja nog te kennen, dat de Sunan hem ook bevolen had, van deze verhuizing ten spoedigste kennis aan de Hoge Regering te geven, terwijl hij hem waarschuwde, geen zwaar geschut steelsgewijs aan land te brengen en niet meer dan één schietgeweer per hoofd. Dit beloofde de resident, nam afscheid van Karti-Djaja en toog aan het verhuizen.

's Middags kwam hem Karti-Djaja met vele groten in de loge opzoeken. Na een zo goed mogelijk onthaal op pinang en wijn, verdwenen zij weer. Blijkbaar hadden zij zich van de goede wil van de resident willen vergewissen. Maar een uur later verscheen de sjabandar en, verklaarde, dat de Sunan weer een Hollandse gezant begeerde, doch geen middel wist, om dit tot stand te brengen. Natuurlijk kon hij wel gezanten naar Batavia zenden, doch hij was te beschaamd, om de eerste te zijn. Luton kon de sjabandar niet wijzer maken.

Die nacht sliep de resident niet al te best in de ontredderde loge, die wel een 300 realen aan herstel zou kosten. Er moest zelfs een metselaar aan te pas komen. Toen Karti-Djaja dan ook de volgende morgen naar Mataram terugkeerde, onderbrak Luton zijn blijvende vestiging in de bouwval. Hierover werd hij op 19 aug 1663 ter verantwoording geroepen door Sabda-Wangsa, een dienaar van de tg. Mataram, kj. Wira-Djaja (D. 5 sept. 1663). Met deze had de resident ,enige redenen over en weer", welke, „omdat het saaken van staet" waren, in een 
„samensprake" werden vervat. Deze vond zelfs opname in het Dagregister.

Het kwam er op neer, dat Luton weinig zin had, om in de loge te wonen, die ,seer vuyl en ontramponeert" was. Sabda-Wangsa daarentegen stond er op, dat hij zonder verwijl de oude loge weer betrok; zo lang als hij in Japara was, moest hij ,des Sousouhounangs ordre soo wel nae ... komen, als de ordre van d'heer Generael'. Hierop reageerde Luton met: „Ghy hebt recht”. Hij beaamde dus ten volle het goed recht van de Sunan om hem bevelen te geven, en verborg dit ook niet voor zijn Nederlandse meerderen.

Terwijl de resident 's middags bezig was de loge te reinigen, kreeg hij bezoek van de regent (patih?) en de sjabandar van Japara. Javanen als zij waren, vielen zij niet met de deur in huis, doch praatten enige tijd over koetjes en kalfjes, tot het hoge woord er uit kwam: Zij verzochten, dat de resident toch de order van de Sunan wilde nakomen, „dewyl hy 't soo begeerde”. De resident maakte bezwaar: hij had al één nacht in de loge geslapen en was nu druk bezig met de grote schoonmaak.

De sjabandar legde er de nadruk op, dat Sabda-Wangsa niet alleen door kj. Wira-Djaja, maar ook door de Vorst zelf gezonden was. Daarom was het maar best, als de resident op staande voet in de loge trok, „schoon dat de logie vuyl en afschouwelyck" was.

Derhalve trok de resident er met de inboedel in, daar men niet weten kon, wat de Sunan, bij ,contraventie van syne ordre, soude willen doen". 1

Het aandringen op een ambassade. 1661--63.

Vóórdat de Compagnie weer in haar Japarase loge werd toegelaten, had zij er wel een gezantschap naar het hof voor over gehad om het

1 Te zelfder tijd werd ook gepoogd, een Nederlandse loge in Gresik te krijgen. Hierover had de Vorst in $1663 \mathrm{kj}$. Angga-Reksa aangesteld. Deze zond kj. lurah Tjipta-Wangsa, Prana-Wangsa en Patra-Naga naar Batavia, om de Nederlanders naar Gresik uit te nodigen (D. 29 sept. 1663). Het zou op last van de Sunan zijn. Het geschenk was agrarisch: 2 lasten rijst, 1 paard, 2 herten, 2 korven kandijsulker, 30 kapoenen.

De resident bevestigde dit voorstel. Men zou er ten woning en vrije handel krijgen. De gouverneur zou die woning zelf bouwen (D. 1 oct. 1663). Doch volgens de resident diende dit voorstel alleen maar, om een schenkage van de Hoge Regeering te krijgen, waarop z.i. nog meer wees. Daarom zou hij zich maar van den domme houden.

Ook de Hoge Regering achtte deze nicuwe residentie ongeraden (D. 19 oct. $1663)$. 
zover te brengen. Men zou de Javanen „hope... geven, dat wy dan een honorable legatie aen Syn Majt. sullen senden" (D. 31 dec. 1661).

Van Mataramse zijde werd voorzeker een gezantschap verwacht. Ng. Marta-Nata, op zijn hoogtepunt, liet naar Japara schrijven, dat „soo haest als er ambassadeurs van Batavia ofte van andere plaetsen quamen, zy alsdan terstond zelve boven zouden komen" (D. 25 nov. 1661 p. 375). Doch zo lang als de resident niet weer in zijn eigen loge toegelaten werd, dacht Batavia niet aan een ambassade, „dewyl het schynt, dat de Javanen maer des te trotser worden, hoe meer dat men haer toegeeft" (res. $31 \mathrm{mrt} .1662$ p. 89). Ook was men er niet zeker van, of de ontvangst behoorlijk zou wezen, immers, zelfs ng. Marta-Nata twijfelde daaraan (H.R. aan Luton dd. 4 apr. 1662). De resident Luton moest daarom maar niet meer over een gezantschap praten, omdat het nut daarvan gering zou wezen (idem dd. 9 juni 1662).

Toen daarentegen de resident niet slechts in zijn vervallen loge werd toegelaten, ja er zelfs in moest blijven, of hij wilde of niet, bestond er, naar Hollandse opvatting, nog veel minder reden om gezanten naar Mataram te zenden. Immers, deze bezendingen dienden, naar het oordeel der Compagnie, het stempel van vriendschappelijk verkeer tussen gelijken te dragen, niet dat van huldebrengende vazallen, gelijk de Sunan begeerde. Het doel, het weder betrekken der loge, bereikt zijnde, bestond er geen aanleiding meer om naar Mataram op te reizen.

Een verzoek om een ambassade bij wijze van dankzegging voor het weer mogen betrekken der loge, beval de Hoge Regering „ongemerckt (te) laten voorbij gaen" (dd. 28 aug. 1663 p. 163).

De Javanen daarentegen verwachtten een dergelijk gezantschap stellig en polsten herhaaldelijk de resident hierover. $\mathrm{Nu}$ en dan vroegen hem de groten, wat Hare Edelen er wel van dachten, dat zij weer in het bezit hunner loge gesteld waren. Luton antwoordde eenvoudig, dat de Hoge Regering het vernomen had, zich erover verbaasde en hem gelast had de loge volgens bevel van de Sunan te bewonen. Dit bevredigde de Javanen allerminst.

Op een andere dag waren de regenten in de loge verschenen, hadden wel anderhalf uur over onbenulligheden gepraat, eer het gesprek op de loge kwam, „deselve zeer pryzende (vanwege haere schoonheyt, scilicet) en vragende, of het de heer Generael niet aengenaem en was geweest, dat de Sousouhounang hem... weder in de logie hadde gestelt?" Luton antwoordde, daarvan in de jongste brieven uit Batavia niets bespeurd te hebben. Een grote vroeg toen: „Heeft d'heer Generael U niet anders geschreven?", waarop de resident zeide: „Jae ..., dat het 
haer Ed. aengenaem was, dat de Sousouhounang met Batavia voortaen in vreede wilde leven" (D. 1 oct. 1663). Na nog wat gekout vertrokken de heren, „soo 't scheen eenigsints verstoort" op de Hollander, die h.i. zowel beleefdheid als intelligentie miste. Ten onrechte evenwel! „Het kon wel syn", vervolgde de resident in zijn brief, „dat dien Vorst nu alle middelen practiseert, om haer Ed. te bewegen tot het doen van een legatie". De kleine man had het er al druk over.

Ten slotte moesten de Javanen er wel ronduit voor uitkomen, n.l. op de 29e sept. 1663, toen de regent Astra-Kara weer bij de resident verscheen en vroeg „of haer Ede. niet en souden kunnen resolveeren, jaerlycx gesanten aen den Sousouhounang te senden, gelyck voor desen en in conformité van het contract" (D. 11 oct. 1663). Luton meende van ja, mits vast stond, dat de gezanten "met behoorlyke eere ende reputatie souden worden ontfangen ende gedimiteert". Daar dit naar Mataramse opvatting een ongehoorde eis was, vroeg Astra-Kara: „Wat eere haerluyden dan soude moeten aengedaen werden". De resident meende, dat hij dit zelf diende te weten, ,dewyl hy een oud man was”. De Javaan wist natuurlijk best, hoe men in Mataram buitenlandse gezanten placht te beschouwen en ontvangen, doch durfde dit niet ronduit te zeggen. Hij was schaakmat gezet.

Op 18 oct. 1663 kon de resident daarom naar Batavia schrijven: „Van een legatie en werdt nu niet meer gerept” (D. 26 oct. 1663). Hiermede was evenwel het vraagstuk der verhouding tussen de beide grootmachten nog niet opgelost, het sluimerde slechts. Immers, zulk een „honorable legatie” diende, naar het scheen, enkel om ,syn aensien ende respect omtrent de gebuyrvolken ... te vergrooten, alsoo hij het dan de naem van hommagie weet te geven, om haer te bewegen, van gelijke te doen" (gen. miss. dd. 21 dec. 1663 d. J. VI, 99). De Hoge Regering hield zich daarom „bot ende syn meninge niet te verstaen”.

\section{Onbehagen na de mislukking. 1663-64.}

Had de dood van de grote gouverneur ng. Marta-Nata het vorstelijk prestige tijdelijk verhoogd - het bracht Palembang aan het schrikken en Makassar ving aan zich te „fortificeren” - des Sunans falen tegenover Batavia kon geen kustbewoner ontgaan. Iedereen had het potdicht afsluiten der havens vaak aan den lijve ervaren; heel Japara zag de posthouders, wel niet zegevierend, maar dan toch metterdaad in hun verwaarloosde loge terugkeren. Het strikt bevel om deze bouwval onmiddellijk te betrekken, moest de mislukking maskeren, doch zal haar juist 
geopenbaard hebben. Een hulde brengend of dank betuigend gezantschap bleef uit. Natuurlijk moet dit het ontzag voor de Sunan, grondslag der Javaanse samenleving, geschaad hebben. Het eerst kan men dit in de Oosthoek verwachten, waar Balambangan al sedert jaren verloren was. Sura-Baja, de eertijds zo bloeiende en zelfstandige handelsmetropool, was door de moorden op pangéran en tumenggung SuraBaja opnieuw ontzag voor de Midden-Javaanse kraton ingeboezemd.

Doch het lijkt geen toeval, dat juist na de mislukking der blokkade de Girische priestervorst, na jaren stilzwijgen, plotseling opnieuw van zich laat spreken.

In 1663 heerste er spanning tussen Giri en Mataram, zodat men slachtoffers vreesde te zien vallen, terwijl zich ook in het binnenland een oppositie roerde. Tot daden kwam het evenwel niet. Op deze spanningen zal in een volgend deel nader worden ingegaan.

Hoe het ook zij, de jaren 1663 en '64 mogen de rustigste van MangkuRat's regering genoemd worden. Zelfs van opzienbarende moordpartijen hoort men niets. Tot deze kalmte kan hebben bijgedragen, dat de Sunan in 1664 ,impotent”, zwaar ziek wordt genoemd, zodat hij geen Palembangse gezanten kon ontvangen. Zo haast hij „reconvaliseerde” zou hem hun verzoek om gehoor voorgedragen worden. Daarom mochten de gezanten over een half jaar terugkomen (D. 17 mei 1664). Ook in Japara hadden de Nederlanders na hun terugkeer in de oude loge het rustig. Hun welgezinde gouverneurs voerden in Japara toen het bewind.

Residenten. $1661-66$.

Helaas werd de Compagnie in de jaren na het herstel der loge niet zo waardig vertegenwoordigd als wel wenselijk was, n.l. door de boekhouder David Luton. Op 2 juni 1664 (D.) bereikte het Kasteel een naamloos schrijven van een Javaans koopman uit Japara, waarin over deze boekhouder een boekje werd opengedaan. Niet alleen had hij het contract met deze koopman niet nageleefd, doch hij gedroeg zich slecht, „soo met d'arme slechte Javanen als de matrosen te travailleren". Vooral in dronkenschap richtte hij ,seer quade stucken aen, grasserende hier en daer langs de straet met bonsen op de deuren en ageren met syn rappier". Thuis gekomen klopte hij ,de matrosen wacker aff, dewelcke dan alle buyten lopen, slingerende hier en daer geheele nachten door". De Javanen schijnen zich tegen deze wanordelijkheden verzet te hebben en dan moest de schrijver hen gaan opzoeken en gelasten huns weegs te 
gaan. Vermoedelijk heeft een der later zo genoemde regerende kooplieden dit leerrijke epistel geschreven.

De Hoge Regering, ontsteld over deze wanorde, verweet haar resident „,met ernstige termen” en gelastte hem, zijn brieven steeds door zijn secunde te laten tekenen (D. 17 juni 1664). Op 10 juli 1664 (D.) ontving zij Luton's ,schultbekentenisse van syn dronken drinken en ongeregelt leven". Hij beloofde beterschap, maar toch bleven de klachten aanhouden (D. 6 febr. 1665). Daarom werd de gewezen licentmeester Simon Simonsz als commissaris naar Japara gezonden, om te zien, „wat huys ... by den boeckhouder, David Luton gehouden" werd.

Op 18 febr. 1665 (D.) vertrok Simon Simonsz naar Japara, voorzien van een uitvoerige instructie: David Luton moest hij dadelijk op het eerste schip naar Batavia te zetten en door zijn secunde, de boekhouder Pieter Brinckhoff, vervangen. Dan diende hij natuurlijk de boeken na te gaan en de handel te bevorderen, maar vooral de Javanen ronduit te zeggen, waarvoor hij kwam. Anders zouden ze hem wellicht voor een officieel gezant aanzien.

Inderdaad trof Simonsz te Japara geen behoorlijke boekhouding aan, doch een ,stel claddige ende ongesloote negotieboekjes van het gepasseerde jaer" (D. 13 apr. 1665). Ook bleek de verhouding tussen de twee boekhouders niet te best te wezen. Luton werd dus naar Batavia teruggezonden.

Simonsz was onderwijl druk doende met het reorganiseren van de handel, met het sluiten van nieuwe contracten met hout- en suikerleveranciers (D. 9 mei 1665). Op 25 juni 1665 (D.) bracht hij rapport uit. Behalve vele financiële malversaties als het berekenen van te hoge prijzen, het niet in rekening brengen van geschenken, het boeken van nooit betaalde onkosten en dgl. meer, gaf Luton's „,ongebonden en vuyl leven" aanstoot, „soo omtrent de Javaense natie, als omtrent ons eygen volck..., dog de eerbaerheyt heeft zyn $E$. sulcx in de penne doen houden". Later blijkt hij twee prinsenstukjes te hebben geland, die inderdaad tegen order en verbod binnen de boom waren gebracht. Daarop had de gouverneur Reksa-Menggala ze in beslag genomen, waarna ze voorlopig in Javaanse handen bleven (D. 15 nov. 1665).

Vermoedelijk tot teleurstelling van de secunde Pieter Brinckhoff, die kort daarop ijlings naar Batavia verzeilde, werd in Luton's plaats de koopman Danckert van der Straeten aangesteld,1 wie Simonsz een

1 Luton, buiten Compagnies dienst zijnde, duikt later weer in Japara op (D. 17 juni 1670) en wel ,seer vol en droncken". Begin dec. 1670 wordt hij er 's nachts door schelmen vermoord. Behalve meer schuld dan bezit liet 
instructie gaf (D. 11 mei en 21 juli 1665). Als secunde trad nu de vermaarde Jacob Couper op, die eens een belangrijke rol op Java's Oostkust zou spelen. Lang bleef Van der Straeten daar niet werkzaam. Reeds het volgende jaar klaagde de nieuwe gouverneur ng. WiraDika over hem: hij was te zelfstandig, wilde naar zijn "onderrichtinge” niet horen. De gouverneur waarschuwde, dat het niet zó zou gaan, als bij de tweede havensluiting (D. 11 aug. 1666). Van der Straeten werd nu naar Ceylon overgeplaatst en vervangen door de onderkoopman Jurriaen Propheet (D. 24 aug. 1666).

Het bewind van Tanu-Menggala. 1663.

Na Marta-Nata's dood ving voor Japara een nieuw tijdvak aan. Als uiterlijk kenmerk kan gelden, dat het „paleis” der gouverneurs niet meer bewoond mocht worden, een duidelijke aanwijzing van vorstelijke gramschap. Daar te beginnen met 1663 sprake is van de „regeringe van den gouverneur Mataram", is aannemelijk, dat Japara sedertdien geen eigen gouverneur meer had, doch door creaturen van de tg. Mataram bestuurd werd (D. 5 juli 1669). Wij horen ook het gerucht, dat de Sunan ,voortaen geen gouverneurs meer maken zou, maer de grooten alle jaaren verwisselen" (D. 30 apr. 1663).

Het zijn ook weinig opvallende, slechts kort optredende figuren, die aan het hoofd der havenstad staan. De merkwaardigste is nog kj. TanuMenggala, en wel omdat hij daarná nòg twee maal Japara bestuurd heeft onder de naam van ng. Wangsa-Dipa, juist in zeer kritieke tijden. Deze Tanu-Menggala zal kort na ng. Marta-Nata's dood zijn aangesteld, omdat hij reeds begin jan. 1663 te Japara wordt aangetroffen (D. 15 apr. 1663).

Hij was uiterst voorzichtig, weigerde de Nederlanders nog een woonplaats aan de wal en verbood de Javanen het uitvaren, ,ja, in zee (te) kyken". Weldra moest hij opreizen en verluidde het, dat de Sunan alweer een ander "opsiender” over Japara aangesteld had (D. 30 apr. 1663). Ten hove had de Vorst hem gevraagd, of de Hollanders op Japara waren, wat zij er deden en of zij weer in hun oude loge woonden. $\mathrm{Na}$ hierop voldoende antwoord gekregen te hebben, vroeg de Sunan

hij ook een door hem bezwangerde Javaanse vrouw na, ,die hy op syn sterven 2 rds. ter maent hadde belooft, onder belofte, dat se het kint niet en soude verwerpen". $\mathrm{Na}$ Luton's dood had deze vrouw gedreigd haar kind te zullen vergeven, als ze geen onderhoud kreeg (D. $18 \mathrm{dec}$ 1670). Couper had haar daarom de 2 rds. maar gegeven, doch de Hoge Regering oordeelde, dat men zich Luton's zaak niet mocht aantrekken (D. 20 jan. 1671). De afloop meldt de geschiedenis niet. 
aan tg. Wira-Djaja schijnbaar terloops, „of het contract met de Hollanders niet en luyde ... om hem, des versoekende, tegens syne vyanden te assisteeren". De stadhouder kon dit niet ontkennen, waarna de Sunan hem beval de Gouverneur-Generaal van een oorlog met Bali te verwittigen; daartoe verlangde hij van hem drie transportschepen. Er kwam evenwel niets van, evenmin als van een zending van $\mathrm{kj}$. TanuMenggala naar Batavia (D. 5 sept. 1663). Was het, omdat hij goed met Nederlanders kon opschieten, dat men hem die zending had toegedacht?

Als bestuurder werd hij in Japara opgevolgd door kj. Reksa-Menggala (D. 21 jan. 1664), wiens gezag zijn grenzen vond in de macht der Japarase kooplieden.

\section{De opkomst der regerende kooplieden. 1665-67.}

De Japarase kooplieden, over wie men tot dusverre weinig vernam, duiken het eerst tegen het einde van het jaar $1664 \mathrm{op}$. Zij heten dan „voorname Moorse coopluyden, aen Javaense vrouwen getrouwt" (J. Cops, dd. 18 dec. 1664; D. 26 mrt. 1665). Blijkbaar wonen zij reeds lang te Japara, waar de handel hun zeer goed ligt. Zij bieden 4 tot 5000 pikol witte broodsuiker (dus rietsuiker) tegen $31 / 2$ reaal het pikol aan. Ook in Mataram kennen zij de weg: volgens hen zou er wel 100 kati goud te krijgen zijn van 16, 18, 24 en 25 reaal de reaal zwaarte. Evenzo paarlen, sappanhout en 10 tot 12.000 stuks buffelhuiden.

Met hen sluit de gewezen licentmeester S. Simonsz begin mei 1665 een contract, waarbij hij de witte suiker tegen 3 , de ,gemeene" tegen $13 / 4$ rd. het pikol krijgt. Levertijd: in juli of begin augustus, wat inderdaad later wordt (D. 20 sept. 1665).

Men vraagt zich af, hoe deze Moorse kooplieden juist in 1664, of iets eerder, zo sterk op de voorgrond konden treden. Vermoedelijk door het dalen van het gezag der strandheren, die niet meer in staat waren, om de handel naar zich toe te trekken of zich als bemiddelaars tussen de Nederlanders en de producenten op te werpen.

Het optreden dezer kooplui trok ook de aandacht van de Sunan en begin sept. 1665 werden zij naar het Hof ontboden, in gezelschap van enige ,subalterne rechters" (D. 29 sept. 1665). Daardoor stokte de suikerlevering voorlopig (D. 13, 19 en 26 oct., 15 nov. 1665).

Er blijkt meer te zijn besproken dan enkel handelszaken. Volgens het gerucht zou er wat bijzonders op til zijn, en wellicht „een groote veranderinge onder de voornaemste van het ryck" ophanden wezen (D. 19 oct. 1665). Op raad der opontboden kooplieden, die zich blijkbaar verdienstelijk wilden maken, had de plv. resident, de boekhouder 
Joannes Keyts een geringe schenkage aan de tweede persoon des rijks, kj. Wira-Djaja, vereerd, hetwelk volgens de resident Van der Straeten, „wel eenige operatie ten dienste van de Compagnie" zou doen.

Toen deze suikerkooplieden eindelijk begin nov. 1665 afkwamen, waren zij niet meer dezelfde. Met enige anderen was hun gelast de „respective comptoiren der Gouverneurs te visiteren”, hetgeen zij ook dadelijk deden. Het resultaat was, dat zij de rekening van de Japarase gouverneur Reksa-Menggala er zeer slecht bij vonden staan. Van de 10.000 hem toevertrouwde rijksdaalders schoten nog 3000 te kort, wat niet veel goeds voor hem voorspelde (Japara 19 nov. $1665 \mathrm{~d}$. J. VI, 172). Voorlopig haalden zij zijn goud, zilver en andere kostbaarheden uit zijn huis en verkochten ze publiek. Dit was het begin van het einde. Op 28 dec. 1665 kwamen ,met eenige expressen” brieven van de Sunan, die uitdrukkelijk de gouverneur gelastten, ook al was deze in het „opbreken... op stondt de achterstallige penningen te comen betalen, denselven de facto uyt syn gouvernement te stooten en datelyck syn huysen, meubelen en anders te vercoopen". Daar hij onmachtig was, de achterstand aan te zuiveren, werd al zijn goed ,,aengetast en vercoght" (d. J. VI, 172). Sedert zien we hem slechts in nederige betrekkingen optreden, b.v. als bode van zijn opvolger ng. Wira-Dikara naar Batavia (D. 15 juli 1669). Hij is dan niet meer dan „regent” van Japara, hoofd der militie en opzichter over de versterkingen. Wira-Dikara laat hem ook de Nederlandse gezant De Jongh aan land roepen (vide diens rapport K.A. 1162 f 842).

Intussen blijken deze suikerleveranciers met nog meer nieuwe taken te zijn belast. De Sunan vertrouwde hun 20.000 rds. toe, en om daarmede winst te maken, richtten zij het gewone verzoek tot de Compagnie om zeepassen naar de Oost, hetgeen natuurlijk geweigerd werd (D. 4 mrt. 1666). Later bleken zij weer van dit bedrag ontlast te zijn, zodat de zeepassen meteen in het vergeetboek raakten. Vlotter verliep de levering van 100 pikols brood- en 400 pikols poedersuiker aan de Compagnie.

Over het algemeen zou men kunnen zeggen, dat er een splitsing in de functies van de gouverneur van Japara had plaats gevonden. Hij was ontlast van fiscale en economische werkzaamheden ten gunste der regerende kooplieden, zodat hij slechts de juridische en militaire in hoofdzaak zal hebben overgehouden. Of iets dergelijks ook in andere havens heeft plaats gevonden, staat niet vast.

Middelerwijl was over Japara een nieuwe gouverneur aangesteld, ng. Wira-Dika.

Verh. dl. 33 
XIII.

\title{
GOUVERNEUR KJ. WIRA-DIKA EN DE KOOPLIEDEN-REGEERDERS.
}

\author{
Aanstelling van kj. Wira-Dika. febr. 1666.
}

Kj. Wira-Dika stamde vermoedelijk uit hofkringen, daar hij vroeger „bewaarder van de schoone schilden in het Mataramsche Hof" was geweest (d. J. VI, 184). Ook had hij eens aan een gezantschap naar Batavia deel genomen en zich daar flink en zelfbewust tegenover de Nederlanders gedragen (D. 4 dec. 1669). Bovendien was zijn dochter een bijvrouw van de Sunan, wie zij tegen het midden van 1669 een zoon schonk (Japara 1 juli 1669 d. J. VI, 182; D. 15 juli 1669). Al deze feiten maakten hem geschikt voor de verantwoordelijke post van gouverneur te Japara. Bovendien zal hij de Sunan zekere beloften gedaan hebben, omtrent hetgeen hij bij de Compagnie zou weten te bereiken, n.l. een gezantschap.

Met zijn ambtsaanvaarding op 11 febr. 1666 scheen een nieuw tijdperk te zijn aangebroken (Japara 11 febr. $1666 \mathrm{~d}$. J. VI, 173). Een grote menigte, zo te voet als te paard haalde hem in, en, wat nog belangrijker is, hij nam ,syn logiment in het ordinaris palleys van de Gouverneurs, daerin sedert den doot van Martanata (eind 1662) nyemant heeft mogen wonen". De bewindhebbers over Japara tussen 1662 en 1666 waren dus niet als echte gouverneurs beschouwd, hij echter wel.

De resident ging hem, na daartoe een wenk ontvangen te hebben, met het gebruikelijke geschenk begroeten en gelukwensen (D. $4 \mathrm{mrt}$. 1666). Zijn zwaardere verantwoordelijkheid kwam o.a. daarin tot uiting, dat de moeilijke regeling der verhouding tot de Compagnie geheel op zijn schouders rustte.

Maar anderzijds werd zijn macht sterk beperkt door een viertal ambtenaren, de regerende kooplieden. Dezen, Karti-Sedana, entjik Japara, Mirma-Gati en entjik Soelon voerden het gezag over de boom en 1000 man; de gouverneur behield slechts dat over het land met 4000 man, ,'t welck sulcken confusie en verwerring veroorsaeckte, dat 
men niet en wist, aen wien men iets most versoecken", meenden de posthouders (D. 8 apr. 1666). Een en ander was niet van een leien dakje gegaan. De zoon van de gouverneur had de kooplui met geweld van de boom „ontzet”, maar ten slotte hadden zij er zich kunnen handhaven, zonder dat echter de vrede volledig was weergekeerd. Tussen de dienaren der beide partijen ontstond een handgemeen over de pasartol (D. 23 apr. 1666). Dit bewijst, dat hun aanstelling ook een fiscale betekenis had.

De Nederlanders hadden eveneens reden, om zich over deze wijziging te beklagen, daar zij aan de boom veel ,quellingen en moeyelyckheden” moesten lijden (D. 18 apr. 1666). Zowel deze kooplieden-regeerders of regerende kooplieden als de gouverneur en zijn aanhangers zonden vertegenwoordigers naar de hofstad om te klagen: de gouverneur zijn zoon, de kooplieden twee hunner (D. 23 apr. en 10 aug. 1666). Soms was hun hofreis vergeefs (D. 13 oct. 1666). De strijd golfde heen en weer. $\mathrm{Nu}$ en dan moesten ze samenwerken b.v. bij een gezantschap naar Batavia; een brief aan de Gouverneur-Generaal werd gebracht door drie gezanten van ng. Wira-Dika: Astra-Kara, die wij later als landregent ontmoeten, Derpa-Menggala en Derpa-Kanḍa, zo mede door twee regerende kooplieden: Karti-Sedana en Mirma-Gati.

$\mathrm{Na}$ Wira-Dika's val - door hun toedoen? - is van hun politieke bedrijvigheid weinig meer merkbaar, hoewel hun personen nog in Japara aanwezig zijn.

Zien wij thans, hoe de gouverneur ng. Wira-Dika in opdracht van zijn heer moeizaam en volhardend gepoogd heeft de Hoge Regering tot een nieuw gezantschap naar Mataram te bewegen, het enige succes, waarmede de Sunan zich voortaan zou moeten tevreden stellen.

Kj. Wira-Dika's aandringen op een gezantschap. 1666-67.

Een aanwijzing van het bestaan ener wrevelige stemming t.o.v. Batavia is het Bantamse gerucht, „dat den Sousouhounang Mataram syn volcq op alle plaetsen dede monsteren, met voornemen om aenstaende droge moesson Batavia te beoorlogen". Als gewoonlijk kwam daar niets van (D. 10 jan. 1666). Blijkbaar peinsde men in Mataram over middelen om het eigengereide Batavia weer tot een gedwee vazal te maken. Men begon kalmpjes aan; er werd een geschenk gevraagd.

Op 7 april 1666 schreef de resident Van der Straeten, „dat den gouverneur Wiera Dycka... (hem) verscheyde maelen moeyelyck gevallen (was), om aen H.E. te versoecken, dat hem een sierlyck kleet ofte yets anders, weerdich om aen den Sousouhounang te vereeren, tot 
een geschenck mochte worden toegesonden", en wel net zoals dit bij de vorige gouverneurs gebruikelijk was geweest. (D. 18 apr. 1666). Werd hiermede op een officieel gezantschap met geschenken gedoeld?

Tevens ondervonden de Nederlanders veel last aan de boom, „meest daertoe gericht, om haer schenckagie af te persen". Men kon er niets dan geduld tegenover stellen en hopen, „dat in de tegenwoordige regeringen, die seer los staet, haest veranderinge sal comen". Ng. WiraDika zou pas door de Kraton gewaardeerd worden, als hij er in slaagde de verhouding tot de Compagnie op voor de Sunan gunstige wijze te regelen.

Daar de schenkage niet vlug genoeg opdaagde, verzocht $\mathrm{kj}$. WiraDika eind mei 1666, dat de resident „uyt synen naem aen H.Ed. wilde schryven om een geschenck voor den Sousouhounang”. Hij was zelfs bereid er een afzonderlijke bode voor naar Batavia te sturen (D. 5 juni 1666).

Ook deze wenk bleef vruchteloos; een krachtiger prikkel was nodig. Zo verscheen op 11 aug. 1666 te Batavia een schrijven van $\mathrm{kj}$. WiraDika, ter begeleiding van een „Javaense speelwagen" (D.). De brief was zeer behendig opgesteld, bevatte geen verzoek, maar een klacht met dreigementen over de posthouders in Japara: „Myn broeders volck verheffen haer selffs ende willen naer myn onderrichtinge niet hooren". Hij waarschuwde, ,dat het niet gaet als voor desen... doen den Sousouhounang op al het volck van de zeehavens en alle coopluyden quaet was" - dus in 1660-61 - maar hoopte, dat Batavia en Mataram één stad zouden zijn, en dat zij, ,gelyck voor desen... quamen en gingen..., oversulcx nu oock gaen en comen". Het geschenk van de wagen met twee last rijst moest ongetwijfeld het bittere dezer aanmaning verzoeten. Stellig werd een herstel der verhouding van vóór 1655 nagestreefd, dus toen er jaarlijks gezanten der Compagnie aan het hof verschenen.

$\mathrm{Kj}$. Wira-Dika's gering succes weerspiegelde zich in zijn weinig eervolle behandeling ten hove. Vóór de opreis had hij de Nederlanders nog om 1000 rds. verzocht, die beleefd geweigerd werden. In de hofstad was hem, zo meldde Van der Straeten, „door den cantselier van 't ryck (de tg. Mataram?) over de 100 man van syn suyte... affgenomen". Hij had „oock den Sousouhounang niet connen te spraek comen, daer nochtans andere gouverneurs en strantheeren al audiëntie hadden gehadt". Er werd zelfs een omslag in het bestuur van Japara gevreesd (D. 25 sept. 1666). De nood dwong de gouverneur ten slotte voor zijn opdracht openlijk uit te komen. 
Een rechtstreeks verzoek om een gezantschap mèt geschenken is vervat in zijn brief uit het hof, ontvangen op 27 oct. 1666 te Batavia (D.), ter introductie van twee boden: kj. lurah Tjitra-Antaka en Karti-Dita, die z.g. om kruiderijen kwamen. Het verzoek luidde: „So broeder iemant gelieft te senden, soo sal 't goet wesen, dat se met myn gesanten... comen: en soo je gesanten sendt, soo sullen twee Persiaense paerden heel wel comen..., als de paerden soo syn als de voorige". Van dit verzoek moet de Sunan geweten hebben (D. 22 dec. 1666).

Op een duidelijke vraag kan ook duidelijk geantwoord worden. De Hoge Regering schreef, dat ,géén legatie aen den Sousouhounangh kan geschieden, voor en aleer meerder seekerheyt hebben, dat deselve hem aengenaem zal wesen, omdat (hij) voor desen te kennen gegeven heeft, daermede niet gedient te syn" (D. 17 nov. 1666).

Batavia achtte Wira-Dika's positie nu hachelijk. De resident mocht hem n.l. geen geschenk geven, eer hij uit Mataram terugkwam en men de afloop wist (D. 24 nov. 1666).

Het antwoord van de benarde gouverneur, per kerende post verzonden, droeg dan ook een dringend karakter: de Sunan begeerde thans drie Perzische paarden. Verder zou het goed zijn, als ,broeder die sèlve laet brengen met calemback (reukhout), amber de grys (ambergrijs) en muscus". Dat had dus veel weg van een bestelling.

Verder kwamen de vier regerende kooplieden de resident nog verzekeren, dat de Sunan bijzonder op een gezantschap gebrand was en meermalen aan Wira-Dika gevraagd had ,nae de Hollanders op Japare, ende waerom den Gouverneur-Generael geen gesanten en sondt, gelyck voor desen" (D. 22 dec. 1666).

Daarop had kj. Wira-Dika opnieuw vijf personen naar Batavia gezonden. Dit waren: Asta Cora (Astra-Kara?), Durpa Bengala (DerpaMenggala), Durpa Canda (Derpa-Kanda), Corty Sadana (KartiSedana) en Mormagaty (Mirma-Gati). Van dit vijftal kunnen wij de tweede als gezaghebber in Grobogan herkennen, terwijl het laatste paar regerende kooplieden zijn.

In hun meegebracht schrijven, waarin $\mathrm{kj}$. Wira-Dika zich meer dan eens op vorstelijk bevel beriep, verklaarde hij de ,geëyste goederen" niet aan de Sunan te kunnen brengen, tenzij er een gezant van de Gouverneur-Generaal meekwam (D. 22 dec. 1666). Ook de resident had een dgl. briefje gekregen.

Toen Speelman op 5 dec. 1666 met zijn voor Makassar bestemde vloot ter rede van Japara het anker liet vallen, wekte dit wantrouwen. WiraDika's zoon liet de berg 's nachts met 2000 man bewaken, ofschoon 
Speelman verklaarde, daar slechts gekomen te zijn, om zijn watervaten te vullen (D. 17 dec. 1666). Regerende kooplieden, uit de hofstad afgekomen, hadden de admiraal verzekerd, dat de Sunan had verklaard, „belust te syn, dewyl hy out (47 jaar!) geworden was, de Hollanders, syn beste en getrouwste bontgenoten, noch eens ten hove te sien" (D. 23 dec. 1666). Dit klonk al wat vriendelijker.

Het vijftal gezanten verliet Batavia op 14 jan. 1667, behalve een geschenk een briefje meenemende, waarin de Hoge Regering verklaarde, ter onderhouding der goede vriendschap, bereid te zijn een gezant aan de Sunan te zenden, mits „het met syn believen en behoudens het respect van de Hollandse natie conde geschieden". Hierop werd WiraDika's mening verwacht.

Inziende, dat kj. Wira-Dika inderdaad uit naam van de Sunan optrad en diens positie thans weer stevig was, had de Hoge Regering zijn boodschappers voor 600 rijksdaalders aan geschenken meegegeven, t.w. behalve de gevraagde kalembak, amber en muscus, een goed Perzisch paard, door hen zelf uitgekozen, ,met hope, dat die costen de Compagnie wel ryckelyck uyt de vrye vaart op voorsz. havens weder incomen sullen". Aan een gezantschap hoopte men door talmen alsnog te ontsnappen, doch dit bleek een illusie.

Immers, de geschenken bereikten hun bestemming niet. Naderhand verweet de resident de op een gezantschap aandringende Javanen, „dat haer Ed.... het versogte paert, den amber etc. aen syne gesanten hadden willen ter handt stellen, maer dat deselve het niet en wilden aenvaerden" (D. 8 juni 1667). De Matarammer wenste huldebetoon, geen kado's.

Op 20 febr. 1667 kwam na een half jaar kj. Wira-Dika weer omlaag, „expres afgesonden om de gesanten... van Batavia... met alle eere ende reputatie te ontfangen ende nevens deselve weder nae boven te reysen; verclarende..., dat den Sousouhounangh seer geerne gesanten van H.E. voor hem soude sien". Hij moet diep teleurgesteld zijn, toen hij slechts geschenken aantrof. Zijn boos humeur blijkt uit zijn antwoord, toen men hem om de twee in beslag genomen prinsestukjes vroeg. $\mathrm{Hij}$ kon ze voorshands niet terug geven, „dogh wanneer (hij) vernam, datter een gesant quam, dan soude hy se weder geven" (D. $23 \mathrm{mrt}$. 1667). De gemene man mompelde reeds over havensluiting, waaromtrent de aanzienlijken zich nog niet uitlieten. Ook het plan van de gouverneur om 3 tot 4 stukken geschut recht voor de loge, aan gene zijde der rivier te planten, was weinig geruststellend.

De geruchten over de havensluiting, ,eenelyck, omdatter geen ambas- 
sadeur van Batavia quam", hielden hardnekkig aan (D. 14 apr. 1667). Te Samarang zou er al last toe gegeven zijn.

De Hoge Regering liet zich echter niet bang maken en stelde een gezantschap uit, totdat het verzochte ,nader bescheyt van den gouverneur Wiera Dycka" was gekomen (D. 2 mei 1667). Zelfs toen zij van Wira-Dika's broeder vernam, dat de Sunan „al weder nae gesanten van Batavia hadde gevraegt en dat hy deselve met groot verlangen te gemoet sagh" (D. 6 mei 1667), besloot zij, zich met het zenden van een gezant niet te haasten, „op hope, dat den Sousouhounangh van sin sal veranderen" (D. 7 mei 1667). Ook geruchten van oorlogen, z.g. tegen Bali of Palembang gericht, vermochten haar niet te doen wankelen.

$\mathrm{Na}$ de verzoeken kwamen echter de dreigementen. De gouverneur liet de resident door vier personen vragen, waarom de gezanten uitbleven, daar hij er al meermalen uit naam van de Sunan om verzocht had en deze ze alsnog begeerde. Hij waarschuwde, ,dat het niet wel en soude afloopen, indien datter geen gesanten en quamen". Ook eiste hij weer eens logehuur (D. 8 juni 1667).

De resident antwoordde eenvoudig, dat het zenden van gezanten in het believen van H.Ed. te Batavia stond. Wat de loge betrof, die was op last van de Sunan gebouwd en de grond ,wel ryckelyck betaelt".

Daags daarna verscheen het viertal opnieuw, ,protesterende uyt naem van den gouverneur, waerom hy in 't versoecken ter ordre van synen here... niet en wert gelooft". De resident diende te informeren, of er gezanten zouden komen of niet. „Indien sulcx geschiede, soude wèl sijn, maer buyten dien qualyck afloopen" (D. 8 juni 1667). De resident volhardde bij zijn vorig antwoord.

Van een havensluiting kwam evenwel niets - dat was een loos dreigement geweest - maar wel begonnen nu allerlei ,vexatiën en onredelyckheden". Alle paardenwachters waren uit de loge geroepen en hun werd verboden de Nederlanders verder te dienen „op sware poene". „Willen de Hollanders gras hebben”, zei de gouverneur, „sy mogen het selve haelen ofte op de basaer (pasar) kopen".

Op 5 juni 1667 kwamen kj. Wira-Dika's broeder en twee sjabandars in de loge om deze op te meten, ten einde er, gelijk van andere erven, „tol ofte gerechtigheyt van te eyschen". Buiten voorweten van de gouverneur mochten de Nederlanders hun loge niet verlaten. Van ieder aankomend schip eiste hij 5 rijksdaalders tol, als het langer dan vijf dagen bleef. Naar zijn zeggen geschiedden deze ,quellingen en vexatiën alleen..., omdatter geen ambassadeur van Batavia quam" (D. 11 juni 1667). 
Een kleine twee maanden verstreken, zonder dat een der partijen ook maar een duimbreed week. Kj. Wira-Dika, die omstreeks half juni 1667 van plan was, weer ten hove op te reizen, liet door sjabandars in de loge informeren, of er nog gezanten kwamen. Daarop vroeg hij de resident zelf, „wat antwoordt hy den Sousouhounang soude geven, ingcvalle deselve nae gesanten quam te vragen". Hierop werd rustig geantwoord, „dat hy daerinne syn gelieven en welgevallen conde doen". Op zijn vertrek liet hij zich nog verontschuldigen wegens de overlast, „,seggende, sulcx door aenstoken van syn raetspersonen te syn geschiet ende dat niet meer en soude gebeuren" (D. 30 juli 1667).

Intussen had de Hoge Regering reeds tot het doen van een bezending naar het Mataramse hof besloten.

De dag na kj. Wira-Dika's terugkeer in Japara - hij had slechts twee dagen in de hofstad vertoefd - liet het schip de „Peerl” het anker op de rede vallen en bracht de zo zeer gewenste tijding. De resident besloot hem deze persoonlijk mede te delen en begaf zich dus naar het koningshof. Eerst vroeg hij aan de gouverneur, ,of de Sousouhounangh de gesanten, indien se quamen, met het vereyste respect wel soude ontfangen". Kj. Wira-Dika verklaarde, ,dat syn heer geen andere meningh had, en dat hy selve daervoor wilde instaen". Nadat de resident nogmaals op de ,vexatiën, quellingen en onredelycke bejegeningen" gewezen had, waarover de Hoge Regering zeer misnoegd was, verontschuldigde kj. Wira-Dika zich en beriep zich op zijn groten. Toen de resident daarop mededeelde, dat er een gezant zou komen, hoorde hij dit ,met sulcken genoegen aen..., dat hy van blydschap nauwelijcx conde spreken". Dadelijk zond hij een dienaar met het goede nieuws naar Mataram. Ook daar was men met de blijde tijding zeer ingenomen (D. 30 aug. 1667). Reikhalzend keek de Vorst naar de ambassadeur van Batavia uit, meldde kj. Wira-Dika.

Hiertoe werd benoemd de koopman Zacharias Wagenaer, die reeds een loopbaan rijk aan veranderingen achter de rug had. Het bekendst is hij als opperhoofd van Desjima (1656-57) en als opvolger van Jan van Riebeeck aan Kaap de Goede Hoop (1662-66); vandaar zijn titel kommandeur.

\section{Het gezantschap van Wagenaer. 1667.}

Op 1 sept. 1667 vertrok de kommandeur Zacharias Wagenaer naar Samarang om vandaar naar het hof op te reizen. De waarde der rijke schenkage bedroeg precies $f$ 44.703:-:3. Behalve twee Perzische paarden met toebehoren werden aangeboden: grote hoeveelheden geweven 
stoffen, opium, gouddraad, rozewater, een spiegel, muskus, ambergrijs, specerijen enz. Bovendien voerde de ambassadeur nog een kist mee, die fraaie kleedij voor zijn „lijfschutten” bevatte, t.w. een sergeant en een trompetter met tien soldaten. Het zal de bedoeling geweest zijn deze pronksoldaten fraai uit te dossen, ten einde op de audiëntie meer indruk op de Vorst te maken. Bovendien werd Wagenaer vergezeld door de Japarase resident Jurriaen Propheet, de onderkoopman Jan de Harde en de eerste assistent Joannes Pit.

$\mathrm{Zijn}$ instructie luidde, niet aan land te gaan of goederen te lossen, „voor (men) ... duydelyck bescheyt van den Sousouhounang heeft, dat met behoorlyck respect sal ontfangen worden: dat S.E. secretelyck sal sien te bewercken, dat het wedergeschenck ... in plaets van rys, mogte geschieden met witte en swarte suycker, partye paerden en timmerhout". Van rijst was de Compagnie goed voorzien. 1

Wat de verdeling der geschenken betreft, de Sunan zou voor de waarde van $f 15.000$ krijgen, de kroonprins $f 3000$ en kj. Wira-Dika $f 2000$, doch deze pas na afloop der hoofse zaken. Voorts diende de gezant de teruggave der twee prinsenstukjes te bewerken en het kantoor te visiteren (D. 1 sept. 1667).

Vijf dagen na aankomst ter rede van Samarang werd Wagenaer op 20 sept. 1667 luisterrijk door de gouverneur kj. Wira-Dika en twee groten, rd. Ngabehi en Wangsa-Karti, expres uit Mataram afgevaardigd, begroet en met tien versierde vaartuigen aan land gebracht (D. 26 sept. 1667). Daar had men voor hem en zijn ,suyte een treffelycke woningh ... toegestelt".

Op 26 sept, 1667 verliet Wagenaer Samarang, begeleid door deze heren en Naja-Tjitra, regent van die plaats. Op 1 oct. 1667 kwam hij in Mataram aan en werd op een half uur afstand van de Kraton ten huize van Wira-Dika ondergebracht. Terstond liet de Sunan een tiental langwerpige korven met boomvruchten aan hem bezorgen (K.A. 1156 f. $979-85$ ).

's Avonds kwam Wira-Dika vertellen, dat de gelukkige aankomst van de gezant de Vorst zeer aangenaam was, dat hij twee dagen zou uitrusten, maar de derde dag de brief en het geschenk aanbieden. Intussen zou men aan niemand, zelfs niet aan de kroonprins, ook maar het geringste schenken, ,want dat souw hij van 't gene van Batavia gesonden was, zelffs wel doen".

1 Zach. Wagenaer kreeg nog een aanvulling op zijn instructie nagestuurd op 17 oct. 1667 (D.) wegens drie door de regent van Wringin Pitu geroofde en niet uitgeleverde slaven, en het herstellen der loge. 
Doch de volgende dag verscheen de gouverneur opnieuw in gezelschap der beide Mataramse hovelingen en vroeg uit naam van de Sunan, hoe de verhouding der Compagnie tot Bantam was, of zij er mee in vrede, dan wel in oorlog was. Wagenaer antwoordde, dat hij van geen oorlog wist en dat de jongste vredesverdragen wederzijds stipt werden nageleefd. Verder informeerde Wira-Dika, wat de Nederlanders tot die vrede bewogen had. Wagenaer zei, dat ,zulcx principael op 't ernstigh aenraden van de pangoran van Jambij geschiet was, overmits hem deselve met eenige andere aensienlycke personen op het ernstigh versoeck van die van Batavia tot middelaars... hadden laten gebruycken". Nadat Wira-Dika hiervan goed op de hoogte was gesteld, beaamde hij: , Nu 't soo is, is 't wel. Den Coninck zal zulcx gaerne hooren", en schreed met zijn gezelschap weg.

Juist op de middag kwamen de vier kjai's weerom en brachten uit 's Vorsten naam weer 20 korven aard- en boomvruchten, verzekerende, dat de Sunan bevolen had dagelijks, zo lang de Nederlanders daar verbleven, 8 stukken van achten en aan dergelijke vruchten voor hen te besteden.

's Namiddags kwamen de vier koninklijke ambtenaren hen voor de derde maal bezoeken en verzochten hun de voor Z.M. bestemde geschenken schriftelijk op te geven, dat zij ,datelijck door een inwoner van Japara ... Marmagattij, die prompt de Maleijtse tale en oock redelijck wel Portugees spreekt in Javaens lieten doen en de gouverneur ter handt stellen".

Maar 's avonds ontbood Wira-Dika de kooplieden De Harde en Propheet in zijn huis, ,dat met 10 à 20 stappen achteruijt te treden te doen was" en begon te spreken over de orde, in acht te nemen bij het gaan naar het hof, en hoe men zich daar diende te gedragen. Daarop verklaarde hij, met de andere kjai's op de lijst der geschenken o.a. gevonden te hebben enige „neusbrillen en ijvoorcompasies”. Deze moesten er afgehouden worden, want de Sunan, die ,altemets seltsame speculatien op die dingen hadde, mochte zulcx qualijck duijden". Wagenaer willigde dit verzoek gaarne in, ,als een geringe zaek”.

Ook drong Wira-Dika er op aan, de kroonprins te bedenken, ,dogh secretelyck en buyten kennis van den Sousouhounangh; verzoeckende meteen, dat de ambassadeur 's Conincks geschenk wat wilde vergrooten, dewyl syn Mayt. van meening was, alle syne kinderen ende oock eenige hovelingen daervan mede te deelen". De gezant deed dit, door er een pak tapesarassen (kleden) bij te voegen.

De derde dag, dus 4 oct. 1667, werden de gezanten voormiddags 
tussen 8 en 9 uur gehaald. Na de eerste poort (tot de aloen-aloen?) gepasseerd te zijn, kwamen ze voor de tweede, waar allen van hun paarden stegen en te voet verder gingen. Vervolgens bereikten ze een groot vierkant plein, de pelataran, waarop enige duizenden mensen zeer ordentelijk achter elkaar in rijen zaten. Dadelijk werden zij de Sunan gewaar, zittende in een „doorluchtig houte huijs” (bangsal kentjana), alleen op een bankje, omtrent een voet hoog.

Z.M. was gekleed als een ,gemeen straet-Javaen”, d.w.z. met naakt bovenlijf en een witte kuluk op het hoofd.

De gezanten werd door Wira-Dika, die tussen de andere edelen in zat, gelast, op 30 tot 35 treden van de Vorst, op de blote, vochtige grond plaats te nemen. Daarna werd hun op vorstelijk bevel de brief door de secretaris Angga-Pradja afgenomen, die kruipende en bukkende tot op tien passen Z.M. naderde, het schrijven opende en voorlas. Vervolgens deed de Vorst enige hovelingen, te dicht bij de Nederlanders gezeten, wat van hen afschikken, blijkbaar om de vreemdelingen beter in het gezicht te krijgen. Hij vroeg ieders naam en bediening en gelastte hen naar huis te geleiden, hetgeen dadelijk geschiedde. Het onderhoud had niet korter kunnen zijn; gesproken was er nauwelijks.

's Avonds verscheen Wira-Dika weer bij Wagenaer en verklaarde, dat de komst van de gezant ,den Coninck aengenaem was geweest, maer die van den heer Van Goens nog veel aengenamer, omdat syn... schenckagie 12 duysent ryckdaelders waerdigh was geweest, zynde de tegenwoordige niet hooger gewaerdeert dan op $7860 \ldots$... Van Goens was ook veel vrijgeviger tegenover de groten enz. geweest. Voorts was het de Vorst vreemd voorgekomen, dat de geschenken niet in de brief zelf, maar in een afzonderlijk memorietje gespecificeerd stonden. Daarop vertrok Wira-Dika weer naar achteren, huiswaarts. Blijkbaar voorzag hij de mislukking van het gezantschap en poogde te redden, wat nog gered kon worden, door de gezant tot meer vrijgevigheid te manen. Later werd vernomen, dat de Sunan zich ook over de geringe talenkennis van Wagenaer had geërgerd, die een gesprek belemmerde. Hieraan viel op korte termijn niets te verhelpen. Of had de Vorst iets op Wagenaer's te trotse houding aan te merken? In ieder geval vermeerderde de gezant zijn gaven niet voetstoots.

Op 5 oct. 1667 werd de ambassadeur door Wira-Dika, kj. Ngabéhi en Wangsa-Karti aangezegd, zich gereed te maken voor zijn vertrek op de volgende dag. Hieruit trok Wagenaer de slotsom, dat het geschenk inderdaad te gering was geweest, te meer omdat Wira-Dika verzekerde, dat als de gezant maar het overschot der kleden bij het reeds aange- 
bodene voegde, hij ongetwijfeld weer tot Z.M. zou worden toegelaten. Blijkbaar vreesde Wira-Dika, dat de mislukking van het gezantschap ook hem zou geweten worden. Wegens "de quade consequentie" trad de weinig plooibare gezant niet in dit voorstel, doch om niet schriel te lijken en met ongenoegen te scheiden, besloot hij het geschenk voor de kroonprins en diens geleiders, zo mede dat voor Wira-Dika, ook al had laatstgenoemde reeds zijn deel ontvangen, aanmerkelijk met kleden te vergroten, en deze nog die zelfde avond of anders de andere morgen te doen overhandigen.

$\mathrm{Na}$ de bekendmaking van dit besluit aan Wira-Dika en andere groten, oordeelden zij juist dit het goede middel te wezen, om het vorstelijk misnoegen weg te nemen. Een en ander werd omstreeks het middaguur vastgesteld, doch terwijl de gezant en de zijnen kort daarop aan tafel zaten, werd ng. Wira-Dika door de nieuwe rijksbestuurder Wira-Karti met zijn gevolg het huis uitgesleept en gevangen naar de Kraton gebracht. Toen hij Wagenaer en zijn gezelschap dicht voorbij ging, gaf hij deze met betraande ogen de hand, zeggende: „Tabe, kapitein, tabe!"

Wagenaer, hierover ontsteld en duchtende, dat Wira-Dika's gevolg huns meesters ongeluk aan de gierigheid der Nederlanders zou wijten, en ,'t selve met een desperaet voornemen ... wreken", stond van tafel op om naar de vendere afloop te zien, doch er gebeurde niets. Naderhand werd vernomen, dat Wira-Dika zich zijn val door eigen schuld op de hals zou hebben gehaald, daar hij door de rijksbestuurder bij zijn Vorst van wanbeheer in Japara was beticht. Niemand dacht anders, ,of het soude hem terstont het leven gecost hebben; maer nog dien eygensten dagh wiert hy van syn ampten, vrouwen, kinderen, slaven etc. berooft ... die landwaert ingevoert" werden. De ,menichvuldige klachten der onderdanen" zouden hem deze val berokkend hebben (d. J. VI, 81).

De kjai's rd. Ngabéhi en Wangsa-Karti bleven onderwijl in WiraDika's ledig huis, hadden ook last om diens geschenk aan de gezant terug te geven. $\mathrm{Zij}$ beloofden dit, mits Z.E. hun een ontvangbewijs verstrekte. $\mathrm{Na}$ de ontvangst van een quitantie, ,soo behielden sy die èn oock de goederen, seggende, dat se deselve al met malcander gepart ende gedeelt hadden". Aldus opgelicht zijnde, besloot de gezant de Sunan geen geschenken meer toe te zenden, daar "niemant den vertoornden Coninck onsentwegen dorste aenspreken".

Daarop betraden de rijksbestuurder en de tolk, Angga-Pradja met nog enige groten Wira-Dika's huis, waarheen ze de gezant ontboden, 
hem de antwoordbrief ter hand stelden en uit 's Vorsten naam verlof, dus: bevel gaven, om 's anderen daags vroeg te vertrekken.

Toen Wagenaer naar de reden van dit haastig afscheid informeerde, zonder de Sunan nog eens te mogen zien en bedanken voor de genoten weldaden „,in ' $t$ doen besorgen van syn taeffel ende ' $t$ bewaecken van syn woonhuys", antwoordden zij, dat de enige reden was, omdat de Gouverneur-Generaal zelf in zijn brief verzocht had, de gezant spoedig naar huis te zenden, anders zou de „Capiteyn Moor" vertoornd worden. Tot begeleiders werden nu aangewezen Wira-Atmaka, gouverneur van Demak en Sabda-Karti, gouverneur van Djuwana.

Op 6 oct. 1667 aanvaardde Wagenaer de thuisreis; 's morgens vroeg, maar nog binnen de bebouwde kom zijnde, werd hij door de rijksbestuurder Wira-Karti en de tolk Angga-Pradja aangehouden, die aan Z.E. en Sr. de Harde „uyt des Conings naem elck een kris ter hand stelden tot een gedagtenis, van dat sy Syn Mayts. aengesigt hadden gezien". Voorts liet de Vorst zich excuseren, „dat hy ter eeren van den ambassadeur niet eenige stucken liet losbranden", daar zijn liefste vrouw 7 tot 8 maanden te voren overleden was. Over dit afsterven zal in een volgend deel nog gesproken worden.

Vier dagen later, de 10e october, was de gezant in Samarang terug en nogmaals vier dagen daarna in Japara, waar hij vernam, dat de kroonprins twee zijner dienaren uit Mataram had afgezonden, om het voor hem bestemde geschenk te ontvangen. Wagenaer liet hun evenwel aanzeggen, dat het nu niet kon geschieden, omdat de Susuhunan het nadrukkelijk had laten verbieden.

Op 19 oct. 1667 beweerden zijn geleiders en de gouverneur van Samarang, dat „Wiera Dycka den Coninck hadde bekent gemaeckt, dat de ambassadeur eenige raere dingen hadde medegebragt, en dat de Mayt. soodanige niet by de schenckagie ... vindende, op ons verstoort was...; om hetwelcke te herstellen sy noodig oordeelden, dat de Gouverneur-Generaal wéder een gesant... sont, of dat hy anders syn havens sluyten ... zouw". Na krachtige tegenspraak ,lieten sy het slippen en verzogten, dat hy daervan niet wilde schryven of spreken".

Het antwoord van de Sunan, op 1 nov. 1667 in het Dagregister opgenomen, behelsde weinig opmerkelijks. Zich noemende Paduka Sri Ratu ing Mataram, ,aen wien by alle Coningen van de Javaense ende Maleytse steeden homagie gedaen wort", meldde hij de aankomst van de „commandeur Zacharias Wagenaer met syn treyn”, benevens brief en geschenk. Hij had er niet meer op te zeggen, „anders als dat ick my 
verheuge". Tot teken van „opregtigheyt" zond hij slechts „,90 drachten salpeter en 90 lasten rijst".

Merkwaardigerwijze heeft de Vorst Wagenaer nog met drie paarden (door de gezanten op de reis bereden?) en een last rijst bedacht (d. J. VI, 109). Toch achtte de Hoge Regering het wedergeschenk slecht, „waeruyt syn ongenoegen niet duyster te sien is". Desniettegenstaande dorsten de afbrengende groten al over een tweede legatie te reppen, „om den Coning tevrede te stellen en voor te comen desselfs gramschap”.

Inderdaad had de Hoge Regering het bij het rechte eind, toen zij meende, dat de Sunan over het gezantschap Wagenaer misnoegd was. Duidelijk bleek dit uit het demonstratief ontslag van kj. Wira-Dika, die zich voor de komst van de Hollandse gezant zoveel moeite getroost had. Men vergelijke deze vertoning met de opzettelijke rijksraad te paard in 1654 (blz. 101). Er heeft in het gezantschap de Vorst iets gehinderd, hetzij het geringe geschenk, het gebrek aan talenkennis of het al te stroef optreden van de gezant. Alle verdere vriendelijkheden zijn als doekjes voor het bloeden te beschouwen.1

\section{Het aandringen op een nieuw gezantschap. 1668.}

Half juli 1668 verspreidde zich in Japara het gerucht, dat de Sunan zou voorgeslagen hebben gezanten aan de Hoge Regering te zenden (Japara 15 juli 1668). Zes dagen later werd dit gerucht zekerheid (Japara 21 juli 1668) door een mededeling der Japarase ,stadtregeerders": rd. Singa-Wangsa en Wangsa-Karti zouden op vorstelijk bevel een brief aan Hunne Edelen zenden. Toen de resident vroeg, of de brief van de Sunan zelf kwam, bevestigden zij dit en voegden er nog aan toe, dat de „Coninck de Palimbangers wilde opofferen, alsoo voor desen onder hem hadden gesorteert; maer overmits (zij) nu meerder (de Compagnie) als hem gehoorsaemden, wilde (hij) niet met haer te doen hebben". Als briefboden werden aangewezen: Wangsa-Patra, WisaMenggala en Wangsa-Nanga.

Terecht wees de resident er op, dat dit maar geringe luiden waren, enkel lurah's, dienaren van groten. Voorts deelde hij mee, dat drie dagen eerder, dus op 18 juli 1668, de stadsregeerders hem ter paseban ontboden hadden. Door hevige koorts was hij verhinderd en had de tolk Jan Bali gezonden. $\mathrm{Na}$ een half uur wachten was deze toegelaten en had het volgende vernomen: de genoemde boden waren inderdaad door

1 Wagenaer is het volgende jaar als vice-kommandeur van de retourvloot gerepatrieerd. 
Singa-Wangsa en Wangsa-Karti afgezonden. De resident werd verzocht tevens een brief te schrijven, waarin hij óók om een gezant aan de Vorst verzocht, ,alsoo groote en gewigtige saken moste(n) verhandelt werden”.

De resident liet door de tolk verzekeren, wel bereid te wezen, om een begeleidend schrijven aan de boden mee te geven, doch dat hij zijn superieuren niet tot het zenden van een gezant kon aanmoedigen. Hierop viel één der regeerders, Astra-Kara, uit: „Den capteijn sal ons sulcken brieff geven; soo (hij) dat niet doen wil, willen (wij) hem gebonden na Batavia brengen", waarop nog meer dreigementen volgden. De sjabandar Imbassadana daarentegen sprak kalmerend, wees op het groot getal Javanen in Batavia, op wie de Compagnie zich zou kunnen wreken.

's Avonds werd voor de haastige woorden van Astra-Kara verontschuldiging aangeboden; de kapitein geliefde slechts een brief mede te geven, ten bewijze dat de briefdragers uit Japara kwamen.

Terwijl in Batavia minder prettige verhalen omtrent gewelddaden van de Sunan tegen zijn onderdanen in omloop waren, verschenen op 1 aug. 1668 de vorstelijke briefdragers ter rede. Twee dagen later werden zij luisterrijk met 19 kanonschoten en musketsalvo's in het Kasteel binnengehaald (D.). Hun Maleise brief werd in de Grote Vergaderzaal plechtig voorgelezen, daarna vertaald. Inderdaad bleek het, zoals de aanhef luidde, ,een minnelycke, suyvere en seer opreghte brieff van den Sousouhounangh Ratoe Mataram", gericht aan zijn broeder, de gouverneur-generaal Maetsuycker.

De eigenlijke inhoud was niet meer dan een verzoek om een gezant. De vorige had de Vorst n.l. niet kunnen spreken, waarschijnlijk omdat hij zomin Javaans als Maleis verstond. Inderdaad was hij wel ontvangen, doch er was geen woord gewisseld. Daarom was de Sunan ,seer vergramt geweest op Wira-Dika", die, naar wij zagen, gevankelijk was weggesleept. Hij wenste dus een taalkundige, opdat hij ,met vreughde van (zijn) hart magh hooren van den welstant van (zijn) broeder".

Bovendien hadden de stadsregeerders de resident nog toevertrouwd, dat de Sunan gewichtige zaken met de gezant te verhandelen had, welke bewering de briefdragers herhaalden of bevestigden.

Aanvankelijk was de Hoge Regering van mening, dat het de Vorst slechts om een groot geschenk te doen was. Hiervoor voelde men weinig, daar men zich niet aan een ,jaerlyckse homagie vast maecken" wilde (d. J. VI, 112). Wél een verschil met een twintig jaar geleden! Maar na de verzekering der gezanten, „hetselve Syn Mayts. meyninge niet te syn, maer alleen om een persoon te mogen hebben, met wien hy saeken 
van importantie conde verhandelen, sonder dat sy evenwel wisten, wat saeken", begonnen de Hoge Heren te weifelen en na overleg besloten zij, „hem daerin te wille te wesen, offer misschien aen gelegen mocht syn".

Vóór 30 aug. 1668 werd dus besloten, de koopman Abraham Verspreet naar Mataram te zenden (D.), om te „onderstaen, wat de Sousouhounangh te seggen" had (D. 4 sept. 1668). Hij kreeg een memorie mede, waarin er op werd aangedrongen, niet op gewichtige staatszaken in te gaan, doch dit „op onvermogen (te) excuseren”. Begeerde de Vorst een langer verblijf, dan was dit desnoods geoorloofd. De brief voor de Sunan bevatte naast handels- en comptoirzaken slechts complimenten.

Intussen werd vurig naar de komst van de gezant uitgezien, vooral in Japara. Toen de resident ten slotte kon mededelen, dat de gezant reeds op weg zou zijn, deed dit de regeerders ,met een blije gelaet ... lachen” (Japara 15 sept. 1668). Ook in Mataram verlangde men naar zijn komst.

Abraham Verspreet was een man van grote kennis, ervaring en bekwaamheid, zowel in krijgs- als in handelszaken. Ter kuste van Malabar had hij zich reeds een goed aanvoerder getoond, terwijl hij te Makassar als opperhoofd in een moeilijke tijd zijn diplomatieke talenten had ten toon gespreid. Van augustus 1666 tot mei 1667 was hij als kommandeur en commissaris over de scheeps- en strijdmacht ter Westkust van Sumatra opgetreden. Als zodanig herstelde hij krachtig het door een zware nederlaag geschokte gezag der Compagnie. Door een merkwaardige overeenkomst met de „keizer van Minangkabau” wist hij daaraan een hechte grondslag te geven. Ook de handel bevorderde hij. Verspreet was dus een alleszins geschikt en flink persoon, die bovendien taal-, d.w.z. Maleiskundig was. 1

Het gezantschap van Verspreet. 1668.

Op 20 sept. 1668 verliet Verspreet Batavia; 10 dagen later werd hij in Japara door de stadsbestuurder feestelijk ontvangen. $\mathrm{Na}$ een week haalden de Mataramse gecommitteerden hem te Samarang in met „seer groote statie, gerammel van gongen, trommelen ende andere Javaense juijchinstrumenten". Aan boord kwamen: Singa Wangsa, gouverneur

1 Voor uitvoeriger inlichtingen raadplege men het proefschrift van dr. H. Kroeskamp: De Westkust en Minangkabau (1665-1668). Utrecht 1931. blz 80-119. Voor zijn kennis van het Maleis, zie Val. IV, 104. 
van Pekalongan, ${ }^{1}$ zo mede de gezaghebbers in Samarang, Demak en Djuwana: Naja-Tjitra, Wangsa-Karti en Wira-Atmaka. Genoemde heren boden een grote hoeveelheid jonge klappers, pisangs en andere vruchten aan. Daarop vroegen zij naar de grootte van het geschenk, welke vraag met de wedervraag beantwoord werd: wat toch het believen van de Sunan mocht wezen. Niemands nieuwsgierigheid werd bevredigd. Onder ,geschutsgedonder en onuijtspreeckelijck geraes der Javanen" ging het gezelschap van het schip in kleinere vaartuigen over, terwijl duizenden nieuwsgierigen toekeken. Het gezantschap werd daarop ,magniefijck genoegh gelogeert" ten huize van de Samarangse gouverneur, die zijn ambtswoning had ingeruimd. Rijkelijk werd men ook hier van landsvruchten voorzien. Kennelijk was de bedoeling der Javanen de Nederlanders een , jaerlijks weerkomen aengenaem te maecken".

Toen men na een driedaags verblijf op 12 october landinwaarts trok, telde het „convoij” wel duizend man, zo bereden als te voet. Hun begeleiders waren de reeds genoemde vier heren, terwijl daar nog als vijfde Singa-Wangsa-Karti van Batang bij kwam. Onderweg verhaalden de Javanen, dat de Sunan, van de komst der Nederlanders op de hoogte gesteld, twee dagen te voren zes personen ,gelanteijt”, d.w.z. van een lanté, statiemat voorzien had, ten teken dat zij verhoogd waren tot op de trap, die de prinsen van den bloede het naast kwam, n.l. ngabéhi. ${ }^{2}$ Tevens had de Vorst ,syne voorgenomen playsierreyse nae de Zuydtzeestrant ... opgeschort, om gemelte ambassadeur met hem mede te nemen" (D. 23 oct. 1668). Onderweg genoot Verspreet van de schone natuur, die in hem in een geestdriftig beschrijver vond (d. J. VI, 176--77). Snel werd voortgetrokken, zodat reeds na drie dagen de hofstad bereikt was. De laatste dag werden, op de tijding, dat de Sunan sterk naar de gezant verlangde, dertien mijlen afgelegd en Mataram tegen de avond van de $15 \mathrm{e}$ oct. 1668 bereikt. Niet ver van de Kraton werd Verspreet met de zijnen gehuisvest en de volgende dag reeds had de audiëntie plaats.

's Morgens vroeg kwamen de groten, die de gezant opgeleid hadden, naar het geschenk informeren, dat hij hun ten slotte toonde. Terwijl hij hiermee bezig was, kwam opeens bevel, om ten hove te verschijnen. Een uur later vertrok men in optocht naar de Kraton. Een ontzaglijke

1 Was deze toen reeds groot gouverneur der westelijke Pasisir?

2 Volgens het Japarase schrijven dd. 18 oct. 1668 (d. J. VI, 176) zouden het er zeven geweest zijn, die tot ngabéhi verhoogd waren, o.a.: Tanu-Menggala tot ng. Wangsa-Dipa over Japara en Wira-Dika tot ng. Wira-Dikara over Lasem en Tuban.

Verh. dl. 33 
menigte belette bijkans de doorgang, het uitzicht geheel. Des te meer viel de doodse stilte op, nadat de derde poort gepasseerd was en men de beboomde pelataran betrad. Vier tot vijfduizend Javanen zaten daar, onbeweeglijk als beelden. Onder de wijde pend̦apa was de Susuhunan met ontbloot bovenlijf gezeten, slechts gehuld in een eenvoudige kain. Een 25 tot 30 vrouwen omringden hem, dragende zijn lijfwapens, zijn tabak, sirih enz.

Zijne Majesteit toonde zich ongemeen vriendelijk. De gezant mocht tot op 10 tot 12 treden van hem af in de open lucht op de grond plaats nemen. Het vorige jaar bedroeg deze afstand 30 tot 35 treden. De brief der Hoge Regering werd door de westelijke opperstrandheer in ontvangst genomen en door de secretaris Angga-Pradja voorgelezen. Daarop liet de Sunan het geschenk, dat zo lang achter de gezant had gestaan, naar voren brengen, opende zelf het kistje en bekeek alles, stuk voor stuk met een vrolijk gelaat. Een mooi en hoog zwart paard, dat rechts tussen twee bomen stond en daar met opzet heen gebracht was, gaf de Sunan aanleiding om mede te delen, dat dit het veulen van een Javaanse merrie en een Perzische hengst was, waarschijnlijk dus een der paarden, hem door de Compagnie geschonken of geleverd. De gezant prees het dier en schatte de waarde in Batavia op 1000 rds. Van de dieren kwam men op de mensen. Het zevenjarig dochtertje van de Vorst verscheen ten tonele en terwijl het de geschenken bekeek, riep de geweldenaar de Nederlanders lachende toe, dat ,sijn dochtertje een seer groot behagen" in hen had. Toen dit zo een uur geduurd had, gelastte hij de gezanten rust te nemen, ten teken, dat het gehoor afgelopen was. Zonder verder een woord te wisselen keerden de Nederlanders naar hun logement terug. $\mathrm{Zij}$ konden deze ontvangst als zeer geslaagd beschouwen.

Gaandeweg kwamen zij achter de ware bedoeling van de Sunan met dit gezantschap, n.l. niet zo zeer om over staatszaken te redekavelen, als wel om Batavia weer aan een jaarlijkse ambassade te gewennen. Vandaar het grootse onthaal! Ofschoon van 's Vorsten tafel rijkelijk bedacht, kregen de Nederlanders toch dagelijks 12.000 pitjis, kleingeld ter waarde van 40 rds., "tot gastos van siry en pinangh", dus ter bestrijding van kleine uitgaven.

Verspreet nam er geen genoegen mee, dat over de zaak, waartoe hij uitgenodigd was, met geen woord werd gerept. Toen hij de Javanen verzocht, dit aan de Sunan voor te leggen, gebeurde er niets, zodat hem onbekend bleef, of zijn protest ooit de Vorst bereikt had. Ook over een spoedig vertrek werd niet meer gesproken, wel over het beloofde ver- 
gezellen van de Sunan op zijn jachtpartij, ${ }^{1}$ waar ten slotte ook niets van kwam. Ondertussen werd men door verscheidene voornamen begroet en beschonken met fruit, „visjes om vissen te vangen”, merkt Verspreet olijk op.

Velen waarschuwden vertrouwelijk, dat men pg. Adipati Anom niet openlijk zou bezoeken of begiftigen, welke vermaning de gezant reeds in Samarang bereikt had. Een uitnodiging van de prins zelf om hem 's nachts in een huis achter het logement te bezoeken, werd daarom beleefdelijk afgeslagen. Hij diende ditmaal te "patienteeren" en zijn boden mee naar Samarang te zenden, ten einde aldaar over enige zaken te spreken.

Verder werd het verblijf in Mataram opgevrolijkt door een uitnodiging van de tg. Mataram. Deze liet zijn dochtertjes voor de gezant dansen. Ook was het jongste zoontje van de Sunan hem drie maal wezen bezoeken en had van de Nederlander een geschenk gekregen.

De vooruitziende Verspreet had in zijn gesprekken met de afgezondenen van de kroonprins ook aan de toekomst gedacht, n.l. aan een mogelijk spoedig afsterven van diens vader. Hij drukte n.l. tegenover de kroonprins zijn hoopvolle verwachting uit, dat „Godt de Heere hem mits den ouderdom sijns Heeren Vaders wel haest tot sijn natuijrlijcken recht soude helpen, wanneer hij sijne vijanden den voet in den neck geset hebbende, ons geene occasie ontbreecken soude, familiaerder met hem om te gaen", terwijl hij tevens verzocht te bewerken, dat „de broederlijcke eenigheijt tusschen sijn Heer Vader en den... Gouverneur Generael ... altijt continueeren mocht".

Toch voelde de gezant zich teleurgesteld over het resultaat zijner zending. De zakelijke bespreking met de Sunan had geen voortgang gehad, ondanks zijn aandringen. Hij meende daarom, dat de strandheren eigenmachtig zulk een bespreking ter tafel hadden gebracht, zonder voorkennis van de Vorst; reden waarom zij het er later niet meer met de Sunan over wilden hebben.

De Matarammer daarentegen moet over dit gezantschap zeer voldaan zijn geweest. In twee achtereenvolgende jaren had hij een Nederlandse

1 De pleizierreis naar de Zuidkust, tevens jachtpartij is een dier half ontspannende, half rituële reizen der Javaanse vorsten naar de Zuidkust geweest, immers de Babad Momana vermeldt onder A. J. 1590 (begin: 23 juni 1667): Ingkang Sinuwun teḍak mbebeḍag ḍateng Redi Kidul, ningali guwa ing Ngirik. Dit hol moet wel de grot van njai Lara Kidul, de godin van de Zuidzee zijn, bekend als guwa Langseh. 
gezant voor zijn troon zien verschijnen en zijn ingenomenheid daarmede stak hij niet onder stoelen of banken. ${ }^{1}$

Het tweede optreden van Tanu-Menggala - Wangsa-Dipa. 1668-69.

$\mathrm{Na}$ het vlot verlopen gezantschap van Verspreet kreeg Japara een nieuw hoofd. Tanu-Menggala mocht als ng. Wangsa-Dipa opnieuw deze havenstad besturen (d. J. VI, 176). Deze was volgens Verspreet's instructie een „mogent heer aen 't hof' en begeleidde onze gezant uit Mataram naar de kust, deze gelegenheid benuttende om hem 's Vorsten verlangen naar een jaarlijkse ambassade op het hart te drukken.

De nieuwe gouverneur bleek niet gans wereldvreemd te zijn: hij dreef handel op Sumatra's Westkust. Daar beroofden de Nederlanders zijn uitgezonden dienaren van 30 korven (wel: corgi's, bundel van 20 stuks) en één stuk ramboetijns (soort Voor-Indische kleden) (D. 15 nov. 1668). Te Batavia was hem daarvoor te weinig vergoed, zodat hij nog 700 rds. te vorderen had. Niettegenstaande dit geschil deed hij echter zeer voorkomend, noemde Batavia en Japara één negotiestad, waarbij het op een 1000 rijksdaalders min of meer niet aankwam (zijn schrijven dd. 1 apr. 1669). Deze hartelijkheid belette hem niet in nov. 1668 vanuit Mataram een geschoren Chinees naar de Engelsen in Bantam te zenden met de boodschap, dat ze hun loge in Japara weer mochten betrekken. Wel achtte de resident dit een „practyk, om een goede schenckagie te crygen”, doch het kan ook wel bedoeld zijn, om de Compagnie in verband met het handelsgeschil onder druk te zetten. Ten slotte werd dit bijgelegd en de Engelsen bleven weg (D. 15 apr. 1669).

Overigens genoten de Nederlanders van hem ,sooveel eer en vrindtschap, dat selve daerover verwondert waeren", schreef de resident naar Batavia. Niemand der oude regenten had meer de courage om de Nederlanders te molesteren; ze moesten hen zelfs te vriend houden.

Dit veranderde bij ng. Wangsa-Dipa's vertrek naar Mataram op het eind van mei 1669 , waarna ,d'onse omtrent de b(oom) van de regenten veel moeyelyckheden leyden" moesten, „soodat na desselfs wederkomste zeer verlangt wiert" (D. 4 juni 1669). Te vergeefs poogde men de kwelgeesten door „,cleene geschencken als vrundelyck onthael geheel tot d'E. Compe. te verbinden" (Japara 28 juni 1669, d. J. VI, 161).

1 Ter bevrediging van mogelijke belangstelling voor verdere lotgevallen van Verspreet zij nog medegedeeld, dat deze kort na zijn terugkeer tot $17 \mathrm{c}$ landvoogd van Ternate werd benoemd, waar hij op 13 mei 1669 aankwam, doch reeds op 7 aug. 1671 kwam te overlijden (Val. I, 326). 
$\mathrm{Ng}$. Wangsa-Dipa kwam pas vele jaren later in Japara terug, en de Nederlanders moesten met minder meegaande figuren zien om te springen.

\section{Het gezantschab van De Jongh afgewezen. 1669.}

Op 30 jan. 1669 schreef de Hoge Regering aan haar resident, ,dat wanneer hem yets mochte voorkomen aengaende de jaerlyckse begroetingh..., daer het op aengeleght schynt..., hy sich dierwegen onwetende sal hebben te houden".

Maar omstreeks juni 1669 was te Japara opnieuw de gewezen gouverneur Wira-Dika aangesteld, sedert genaamd ng. Wira-Dikara (D. 5 juli 1669). Wel was hij twee jaar te voren met schande uit Japara verwijderd, doch, gelijk wij zagen, tot gouverneur van Lasem en Tuban aangesteld. Daar voelde de familie zich spoedig op hun gemak, aangezien zijn zoon, kentol Suta-Nanga in Lasem de bekende rol van plager der onderdanen ging spelen, door van af te schepen balken $50 \%$ tol te eisen (D. 11 juni 1669).

Naast ng. Wira-Dikara was in Japara tot groot-sjabandar aangesteld ng. Wira-Atmaka, regent in Djuwana. De Hoge Regering achtte beiden „wrede en onredelycke menschen", die hun bevordering dankten aan de belofte van ,te sullen bewercken, dat de Compagnie jaerlycks een geschenck van 10.000 rds.... soude moeten doen", ter voldoening aan het vredesverdrag (D. 5 juli 1669). Dus al weder, net als tien jaar te voren, de befaamde 10.000 rds.! Daartoe zou ng. Wira-Dikara boden naar Batavia sturen. Ging de ambassade door, dan zou dit strekken „tot syn verheffingen, ofte anders tot zyn geheele ruine”. Door zijn dochter, een bijvrouw van de Sunan, ,wiste hy veel uyt te wercken”, daar de Vorst bij haar een zoon ,geprocureert" had (D. 15 juli 1669). Zijn vorige afzetting weet hij aan intriges, doch nu had de Sunan de waarheid gezien, enz. Voor een gezantschap garandeerde hij een goede ontvangst. Zijn zoon, kențol Suta-Nanga kwelde ook in Japara de inwoners, die een verhuizing overwogen. Van iedere koe eiste hij 1/2 rd. tol.

Ng. Wira-Dikara's eerste brief, door de afgezanten Reksa-Menggala en entjik Salam naar Batavia gebracht, was vriendelijk en dringend van toon. Bijna smeekte hij om gezanten, ,en soo broeder mynen raedt niet en volght, soo en sal ick niet konnen staende houden de vereeniging van Batavia ende Mataram als één plaets". De kwade gevolgen zouden voor hem, ng. Wira-Dikara zijn. Enige Javanen verzekerden, dat dan „hy en zyn soon wellight niet lange regeeren ofte oock wel niet lange 
leven" zouden (D. 29 juni 1669). Op 28 juli 1669 besloot de Hoge Regering in beginsel tot het zenden van gezanten. Doch eer dit omstreeks half aug. $1669 \mathrm{ng}$. Wira-Dikara ter ore kwam, had hij nog meermalen op een gezantschap aangedrongen.

Op 7 aug. 1669 kwam n.l. nog een tweede schrijven van ng. WiraDikara, gebracht door de boden Mirma-Gati en entjik Sulong (Soulangh). De toon was uiterst beleefd, maar geschenken ontbraken. Er was ook een aanmerking over Compagnies optreden te Makassar, dat de Vorst geprikkeld had. De Nederlanders hadden beloofd iemand in augustus te sturen. Deze moest de Sunan behoorlijk „op zijn reden” kunnen dienen (D. 7 aug. 1669).

De boodschap van een derde bezending, die op 9 aug. 1669 te Japara aankwam, sloeg een hoger toon aan. De Nederlandse gezant zou een „importante schenckagie" dienen mee te brengen, daar de Compagnie dit volgens het met Gouverneur-Generaal Van der Lijn gemaakte contract verplicht was jaarlijks te doen. $\mathrm{Zij}$ was nu al jaren ten achter. Kwam er geen ambassadeur, dan zouden de havens gesloten worden (D. 13 aug. 1669; ook D. 29 aug. 1669). Deze derde boodschap is blijkbaar niet meer zo naar Batavia doorgezonden, daar intussen de blijde tijding, dat er een gezant naar Mataram zou opreizen, door de teruggekeerde eerste briefdragers Japara bereikt had, waarover ng. WiraDikara's zoon, kențol Suta-Nanga „seer verblyt was, hebbende oock t' zedert ... van zyn vexatiën en quellingen t'eenemael afgelaten" (D. 24 aug. 1669). Het derde stel briefdragers, Reksa-Menggala, entjik Salam en Derpa-Wangsa, dat op 29 aug. 1669 Batavia bereikte, bracht ook een heel andere boodschap, dan de oorspronkelijke (D.). Ng. Wira-Dikara sprak er zijn voldoening over uit, dat de Hoge Regering over één of anderhalve maand een ambassadeur zou zenden en naar de wensen van de Sunan informeerde. Deze werden nu medegedeeld: een groot aantal soorten textiel en (gemunt?) zilver. Er was haast bij het zenden van een gezant.

Men was dus ongeduldig op Java's Oostkust. Te Djuwana was met het sluiten van de haven reeds een begin gemaakt, maar nog niet in Japara, daar kj. Wira-Dikara enkel maar wachtte op de gezanten van de Gouverneur-Generaal om met dezen naar Mataram te gaan (D. 6 sept. 1669). Ook de rivieren van Rembang, Demak en Samarang werden reeds toegepaggerd. Er klonken dreigementen, daar de Sunan tegen ng. Wira-Dikara zou gezegd hebben: „Gaet na Batavia ofte sent yemandt derwaerts om te vernemen, of de Cap. Moor een ambassadeur wil senden; soo niet, sal ick de stranden sluyten". De Sunan zou 30.000 man 
zenden, om de $\mathrm{Tji}$ Liwong in het gebergte af te snijden en in de Krawangse rivier te leiden (D. 6 sept. 1669). Zelfs de boom te Japara werd gesloten en slechts de Chinezen wisten er nog enige met suiker geladen vaartuigen door te krijgen (D. 10 sept. 1669). Ook had de Sunan, misnoegd over de oorlog der Compagnie in Makassar, gevraagd, „offer aen de stranden wel duysent oorlogsvaertuygen in voorraet waeren ... tegens Jaccatra". Doch eerst wilde hij nog even afwachten, of er een ambassadeur van de Gouverneur-Generaal kwam of niet (D. 13 sept. 1669).

Intussen had de Raad van Indië besloten, omdat men de levensmiddelen en anderszins niet kon missen, hoe eer hoe liever een gezant aan de Susuhunan Mataram te zenden en wel de gewezen resident van Ternate, Maximiliaan de Jongh (D. 3 sept. 1669, 5 sept. 1669). Aan ng. Wira-Dikara werd dit gemeld met de waarschuwing, ,dat de ambassadeur, byaldien hij de havens geslooten vindt, genootsaeckt sal wesen, weder herwaerts te keeren". In zijn instructie stond ook, dat hij niet eer van boord mocht, alvorens van een eervolle ontvangst en audiëntie verzekerd te zijn. Zouden de havens nog gesloten zijn, dan diende hij een terugkeer te veinzen. Ook moest hij ng. Wira-Dikara over een tegengezantschap aanspreken. De geschenken kon hij naar bevinding verdelen, doch in het geheim, mits hij de Sunan niet afgunstig maakte. Zijn meegebrachte brief bevatte slechts complimenten (D. 18 sept. 1669).

In Mataram werd naar de gezant reikhalzend uitgezien. Volgens kențol Suta-Nanga vroeg „S.M. dagelycks wel 2 à 3 mael, waer de ambassadeur soo lange bleef". Ten aanzien van Makassar sloeg hij nu een andere toon aan, waarover hierna (p. 189) uitvoeriger zal gesproken worden. Intussen waren ook de havens weer geopend, „niet op de tydingh, datter een ambassadeur quam, maer omdat den Sousouhounangh was aengedient, dat het sluyten ... de komste van den ambassadeur soude verachteren ofte wel geheel terugge setten". Ook beweerde kentol Suta-Nanga nu, dat de havensluiting had plaats gevonden, omdat Z.M. op enigen zijner strandheren „verstoort” was (D. 30 sept. 1669).

Toen de gezant De Jongh op 28 sept. 1669 te Japara was aangekomen, vond hij alle havens geopend. Hij werd door kențol Suta-Nanga hartelijk ontvangen, doch wilde niet aan land gaan, voordat diens vader verscheen. Wederzijds onthaalde men elkaar op vruchten tegen confituren en Spaanse wijn. In gezelschap van Jacob Couper zou de ambassadeur naar Mataram reizen, daar hij van diens uitstekende kennis van het Javaans veel nut verwachtte. 
Omstreeks 1 oct. 1669 vertrok De Jongh naar Samarang, waar hij op de komst van kj. Wira-Dikara wachtte. Deze was op 6 october, laat in de avond aangekomen, maar 's anderen daags vroeg al weer naar boven vertrokken (D. 18 oct. 1669), ,zynde door een expresse post weder teruggeroepen". Zijn zoon vroeg de gezant, enige dagen te willen wachten, doch deze stelde een termijn van vier of vijf dagen in verband met de doorbrekende westmoeson. Ook informeerde de kentol naar de aard van het geschenk. De Jongh veinsde echter onwetendheid, wist wel, dat de waarde aanzienlijk was, terwijl hij zijn ondervrager in het oor fluisterde, dat hij ook een goed geschenk voor zijn vader had meegebracht. Contanten waren er niet bij, wat teleurstelling baarde.

Juist acht dagen later, op 15 oct. 1669, kwam Wira-Dikara in Samarang terug en ontbood de ambassadeur door de regenten Mirma-Gati, Reksa-Menggala en entjik Sulong, ten einde het bevel van de Sunan te vernemen. De Jongh weigerde hoffelijk, oordelende, dat hij evenals zijn voorgangers eerst aan boord diende verwelkomd te worden. Daarop verscheen $\mathrm{kj}$. Wira-Dikara met vier Mataramse hovelingen en drie strandheren bij de Nederlander aan boord, nadat hij eerst door datuk Salam had laten verzoeken, over de voor hem bestemde schenkage te zwijgen.

$\mathrm{Na}$ enige complimenten deelde Wira-Dikara aan de ambassadeur de last van de Vorst in het Maleis mede, dat door de assistent Jacob Couper in het Nederlands vertaald werd. Het bevel luidde: de komst van de ambassadeur was hem hoogst aangenaam, „maer alsoo hy eenige onlusten en moeyelyckheden met zyn soon en andere grooten hadde, soo en quam 't hem niet gelegen den ambassadeur te ontfangen, en moght de ambassadeur dienvolgende vryelyck weder vertrecken; wanneer de saecken weder in gerusten staet herstelt waeren, soude hy een gesant aen d'heer Gouverneur-Generael... senden ende den gesant weder ontbieden". Doch Wira-Dikara wist niet, of deze ommekeer over twee dagen, twee weken, één maand, twee maanden of nog later zou plaats vinden. Alle andere groten bevestigden deze woorden als het bevel van de Susuhunan. Op de vraag, wanneer hij vertrekken wilde, antwoordde De Jongh: „Nog deze avond”. Ook vroeg Wira-Dikara, of er vaartuigen met rijst naar Makassar mochten varen, waarop de ambassadeur antwoordde: „Ja, en hoe meer hoe liever, mits voorzien van een pas". $\mathrm{Na}$ een onthaal op wijn en confituren, vertrok Wira-Dikara met zijn gevolg.

's Avonds lichtte De Jongh het anker en kwam op 13 oct. 1669 ter rede van Japara, waar hij ernstig onderzoek deed naar de oorzaak der 
verhindering van de ambassade. Zekerheid werd niet verkregen, daar verschillende verklaringen werden gegeven: te weinig geschenken, het ontbreken van een geldgeschenk, de 18 jaar achterstallige logehuur, het aflopen van Palembang in 1659 en nu weer de oorlog met Makassar, zelfs oorlogsplannen tegen Batavia. De gezant meende, dat het 's Vorsten toorn op Wira-Dikara was, omdat deze ,met sulke impertinentie en op zodanige onredelijke wijse ... een ambassadeur... gevordert" had. De groten, die Wira-Dikara ,seer ongenegen” waren en niet konden geloven, dat er een ambassadeur zou komen, zonder gebruikelijk voorafgaand Matarams tegengezantschap, hadden dit aandringen aan de Sunan gemeld. Deze was daarop zeer ,beschaempt" geworden en had besloten de ambassadeur ,onder een goet en vrundelijck afscheijt wederom te laten... vertrecken". Naar Wira-Dikara werden vier hovelingen gezonden, om op al zijn doen en laten te letten, vnl, ten opzichte van de Nederlanders. Ook dienden ze te vernemen, of er ook geschenken voor Wira-Dikara meegebracht waren en hoe die er uitzagen. In elk geval was Wira-Dikara met zijn zoon dadelijk na zijn boodschap aan de gezant weer van Samarang vertrokken.

De Jongh meende, dat de zaken der Compagnie in Mataram daardoor niet verergerd waren, en dat men de havens niet licht weer zou sluiten (D. 18 oct. 1669 ; K.A. 1162 f 842 en vlg.). Dit bleek een juiste prognose.

Gezien de verdere lotgevallen van ng. Wira-Dikara is het zeer wel mogelijk, dat diens al te sterk aandringen op een gezant uit Batavia de Sunan heeft doen besluiten deze niet te ontvangen. Doch evenzeer kan het huiselijk ongenoegen ten hove de Vorst in dit besluit versterkt hebben. Het lag natuurlijk in Wira-Dikara's lijn, dat hij alleen dit als oorzaak noemde. Doch ook de bemoeienis der Compagnie met Makassar zal de Matarammer geërgerd hebben.

\section{Indruk van Makassar's vcrovcring. 1669.}

Het was gebruikelijk ook op buitenposten uiting te geven aan de vreugde wegens behaalde overwinningen. Zo was n.a.v. de Vierdaagse Zeeslag ook naar Japara bevolen, deze zege ,door het aenstellen van vreughdetekenen te verbreyden" (D. 18 febr. 1667). Daarom liet de resident wegens de op Makassar behaalde overwinning ,eenige schoten met musquets uijt de logie" doen, ,'t welck omtrent duyrde tot middernacht, als wanneer kențol Soutanangan..., de zoon van den gouverneur... sulcx liet verbieden, met byvoeging, dat hy seer vertoornt en 
gram was". De resident liet daarop brutaal antwoorden, ,dat hy wel konde geloven sulcx de waerheyt te zyn" (D. 13 aug. 1669). Deze zegepraal scheen de Javanen zelfs feller te maken, daar juist nù sterke geruchten liepen, dat de havens met de nieuwe maan gesloten zouden worden in verband met het uitblijven van een Nederlandse ambassadeur (D. 24 aug. 1669).

Ook de Sunan zou „niet wel tevreden over de victorie (zijn) ... en de navolgende woorden gebruijckt hebben: Eerst heeft de Compagnie Palembang verovert en van onder myn gehoorsaemheyt afgetrocken, ende nu jongst Macassar; soo doende soude het $m y$ op 't laest oock wel gelden". Daarop had hij gevraagd, of er aan de stranden wel 1000 oorlogsvaartuigen gereed lagen, om die „tegens Jacatra” te gebruiken (D. 13 sept. 1669).

Ten slotte nam de Vorst na het voldongen feit een kwasi-edelmoedige houding aan. Na gevraagd te hebben, of de victorie op Makassar bevochten, inderdaad waar was, voegde hij daaraan toe: „Dat hy diegeene, die tegen zyn broeder, Capitain Moor, opstondt om te oorlogen, soodanigh aansagh, alsof se hem selfs beoorlooghde; en wilde oock den Capitain Moor daertegen adsisteren, wanneer hem sulcks bekent gemaeckt wiert".

Terecht zag de resident dit laatste ,voor een vercierde logen aen" (D. 18 sept. 1669; d. J. VI, 192-93). Deze „leugen" komt echter overeen met 's Vorsten uitlatingen over Palembang's verovering (D. 13 juli 1668), of over het uitdrijven der vreemdelingen, waarvoor hij de tg. Mataram kj. Wira-Djaja liet boeten (D. 20 sept. 1661 p. 283). Hij schikte zich in het onvermijdelijke en gaf er een schone schijn aan.

Ng. Wira-Dikara's misnoegen. 1669.

$\mathrm{Na}$ de afwijzing van het gezantschap De Jongh was het humeur van Wira-Dikara verschrikkelijk, en geen wonder. Door de weigering de Nederlandse gezant te ontvangen ging de gehoopte winst aan prestige zijn neus voorbij. De resident Amelis de Vallee klaagde dan ook over zijn „onverdraegelijcke vexatiën" na zijn terugkeer uit Mataram. Toen de resident hem met een "fyne chits" kwam begroeten, nam hij deze wel eerst aan, doch gaf hem daarna weer terug, „omdat se hem te geringh was" (D. 3 nov. 1669). Daarna voerde hij een stekelig gesprek. „Eerst vraegde hy ... hoeveel rivieren, datter om Batavia waeren, waerop geantwoort wiert van wel 5 , die onmogelyck waeren te stoppen ofte dempen, en schoon sulcx al konde geschieden, dat dan binnen de stadt 
maer een put behoefde gegraven te worden, waeruyt men water genoegh soude konnen bekomen". Wira-Dikara lachte er om, daar hij het niet kon geloven.

Van ieder aankomend schip eiste hij voortaan $10 \mathrm{rds}$. ankergeld. Ook verbood hij zonder zijn voorkennis iets buiten de boom te vervoeren, ,soodat d'onse voor 10 hoenders... 14 stuyvers voor thol moesten betalen". Op deze onbillijkheid gewezen, antwoordde hij, ,daertoe last en ordre gegeven te hebben, alsoo hy van de Compe. tot Japare geen voordeel en trock, nadien de schepen na andere plaetsen gesonden en aldaer afgeladen wierden, 't welck hy nu niet meer en wilde toestaen". Ook had hij aan die van Padjangkungan en Rembang verboden, hout aan de Compagnie te leveren. Verder verlangde hij, dat de resident 2000 pikol suiker van hem overnam enz. Zelfs de waakhonden in de loge hinderden hem, zodat hij ze, als ze niet weggedaan werden, zou laten krissen. Ten slotte wilde hij een brief naar Batavia schrijven met het verzoek, ,om over de Hollanders te mogen commanderen, gelyck over zyn onderdanen de Javanen, 't welck hy meende, dat hem niet en soude kunnen geweygert werden".

De resident stelde daarom voor, naar Djuwana te verhuizen, ,waertoe hem de gouverneur aldaer, keey Sabda-Carty, menighmael hadt aengesoght". De beste kleden en de contanten waren al op een slocp, de „Hector", in veiligheid gebracht, waarover Wira-Dikara zeer misnoogd op de sjabandar was.

De brief van 6 nov. 1669 was al niet veel opwekkender (D. 13 nov. 1669), ,zynde al weder vol klagten over de quellingen en vexatiën van... Wiera Dykara, dewelcke aen de passer- ofte marcktzitters verboden had, yets aen d'onse te verkoopen'. De resident had hij gedwongen 1350 planken van hem over te nemen tegen een reaal de 100 duurder dan de marktprijs. Toen deze aan de gouverneurs zoon, kentol SutaNanga verklaarde, naar Demak of Djuwana te willen verhuizen, kreeg hij ten antwoord, „dat sulcks konde doen en datter niemandt was, die het hem belette".

Toen het fluitje „Hooghcarspel” op vertrek stond, werd de resident geroepen en kreeg na 2 uur wachten een brief voor de Hoge Regering mede, waarin de vereisten voor een nieuwe gezant stonden: ,goet Maleyts spreecken", een rijk geschenk, ,meerder als voor desen". Toen hij bij de laatste gezant, De Jongh, naar het geschenk geïnformeerd had, kreeg hij geen antwoord, wat hem verdriet deed, ,want het goet of quaet komt alles op my aen". Sterk legde hij de nadruk op het één maken van Batavia en Mataram. 
Een brief van 10 nov. 1669 (D. 14 nov. 1669) meldde de toeneming der vexatiën, „en zyn onredelyckheyt wiert hoe langer hoe grooter”. Zelfs van aan boord van de „Hector” teruggebrachte onverkochte kleden eiste hij tol, t.w. $10 \%$ voor het invoeren en nogmaals $10 \%$ voor het weer uitvoeren. Van de loge wilde hij 18 jaar huur, n.l. 60 rds. p. j., totaal 1000 rds. De uitvoer van suiker bleef verboden, tot de zijne verkocht was aan Chinezen ò de Compagnie tegen $31 / 2$ rds. de witte en 7 rds. de kandijsuiker het pikol. Een Maleise slaaf van de resident werd door zijn zoon aangehouden. Zelfs zou deze op Jacob Couper een aanslag hebben laten plegen door een zekere Pagiwa. Tot 2-3 maal toe was hieraan een begin van uitvoering gegeven. Deze Pagiwa had trouwens meer op zijn kerfstok.

Enige weken later bezocht de resident de gouverneur, de handen vol geschenken: textiel en rozewater, „om te onderstaen, of hy hem van zyn onredelykckheyt niet en konde afleyden”. Alles was vergeefs, „hy bleef by zyn ouden sangh en wilde het gebiet hebben, soo wel over 's Comp. dienaeren als over de Javanen”. „De voorige gouverneurs", zei hij, „waeren by hem in qualiteyt niet te (ver)gelycken geweest". Daarop volgde een staaltje van zijn flinkheid tijdens zijn deelneming aan een Javaans gezantschap in Batavia. In tegenwoordigheid van de Gouverneur-Generaal had hij een onderkoopman voor de borst gestoten en zijn hand op de kris gelegd, omdat deze beweerd had, dat de Hollanders koningen over de zee waren. Dit was een belediging voor zijn Vorst! Als zijn metgezellen het niet verhinderd hadden, zou het daarbij niet gebleven zijn, en zulke praatjes meer (D. 4 dec. 1669).

Het werd zo bont, dat de Hoge Regering de resident toestond, „op de voeghlijkste wyse op te breecken ... na Javana ofte Damack" (D. 20 dec. 1669). Spoedig evenwel was het met de hoge sprongen van $\mathrm{kj}$. WiraDikara gedaan, en wel voor goed.

Ng. Wira-Dikara's val en dood. 1670-72.

De Sunan schijnt zich de mislukking der pogingen om voor 1670 een nieuw gezantschap te krijgen sterk te hebben aangetrokken. Vernemende de "quade en onverdragelycke regeringe van Wira-Dikara", die „buyten last ofte ordre... gesanten van Batavia hadde versocht", besloot de Vorst ,denselven het gouvernement af te nemen” (D. 21 febr. 1670).

Op ultimo febr. 1670 vond de bewindsoverdracht aan Wira-Dikara's opvolger, de groot-sjabandar Wira-Atmaka plaats. Reeds op 24 dec. 1669 
was deze in Japara aangekomen en terstond had hij zijn voorganger van alle „strantsmiddelen" rekenschap laten afleggen (d. J. VI, 183). Daarop was ng. Wira-Dikara verbannen naar een „seer verachte plaets omtrent Balimbangan, genaemt Blitar". Velen meenden, dat hij er zou gekrist worden, doch juist toen hij er zich heen wilde begeven, had de Sunan hem ontboden. Bij zijn verschijning ten hove had de Vorst gezegd: „Geduurich als ik $\mathrm{U}$ in een gouvernement stel, hoor ik klagten van Uwe onredelycke regering; om welke oorsaak $U$ dan te vermoorden, zou jammer zyn; gaat heen in de oude bediening" (d. J. VI, 184). Met deze laatste bedoelde Z.M. zijn taak als „bewaarder van de schoone schilden in het Mataramsche Hof". Daar bleef hij voorlopig.

Op den duur kon ng. Wira-Dikara weer iets pretenderen. In dec. 1670 had hij ,onder het doen van een voetval aen den Sousouhounang versoght om de restitutie van 9000 rds...., syn particuliere penningen, die hem door Wierat-Macka mèt het gouvernement waren afgenomen" (D. 18 dec. 1670). Iets meer dan de helft was hem toen uitgekeerd (4701 rds.).

Maar in mei 1672 was het met hem gedaan, daar de Sunan hem „des morgens met d'eertytel van Tommogongh Madioen vereerende ende des naermiddaghs al lachende seyde... : de Tommogongh Madjoen is een groot man, mits daerop (daarom?), ghy Mataramse volckeren, doot hem!" Toen werd hij dadelijk met al zijn kroost, „tot des Coninckx concubijn incluys", omgebracht. Een graf werd hun ontzegd; de lijken liet men de rivier af in zee drijven (d. J. VI. xcvii, 196).

\section{Laatste aandringen op een gezantschap. 1670.}

In het voorjaar van 1670 meldde de resident uit Japara, dat de nieuwe gouverneur Wira-Atmaka zich nog vriendelijk gedroeg, maar dat het tegen augustus of september, ,wel weder mochte haperen en op de oude quellingen aendrayen, nadien al voorbereytselen gemaeckt wierden, om een ambassadeur... te hebben" (D. 16 apr. 1670).

Inderdaad informeerde de gouverneur volgens een schrijven, dat op 4 mei 1670 Batavia bereikte (D.), omzichtig naar wat er met vorige gezantschappen geschied was, ,alsoo ick dat noch niet en weet, of 't quaet of goet is geweest - maer nu soo verlaet ick my op broeder, alsmede wat broeders begeeren mach syn, opdat myn hert mach vergenoegt wesen”. Als de Sunan er eens naar vroeg, of „,broeder hem oock houdt aen 't contract van den voorigen capitayn Moor Panjangh off niet", zou hij zijn Vorst gaarne van antwoord willen dienen, opdat 
zijn hart gerust kon zijn. „Isser in die tydt een contract gemaeckt of niet?" Hij herinnerde dus aan het vredesverdrag, gemaakt met G.G. Van der Lijn.

Dit schrijven beantwoordde de Hoge Regering pas een maand daarna (D. 3 juni 1670). Kort geleden was nog een gezant gezonden, maar het kwam Z.M. niet gelegen hem te ontvangen. Daarom was het maar het beste, als Z.M. zijn wens zelf aan de Gouverneur-Generaal bekend maakte, die dan ook bereid was, ,, hem ten principalen en in saecken van belangh daerna te reguleren". Met deze nietszeggende fraze besloot de Hoge Regering haar antwoord.

Wederom een maand later waren de gouverneurs van Japara, Samarang en Djuwana (Demak ontbreekt aan het bekende viertal) met andere groten ontboden, om, gelijk Wira-Atmaka veronderstelde, te spreken over het sturen van een gezant naar Batavia. Dit is echter het laatste, wat men er over verneemt (D. 6 juli 1670). Dit is geen wonder. Bij de toenemende verwarring ten hove kon de Sunan een Nederlandse gezant allerminst een waardige ontvangst waarborgen, terwijl ook de macht, om op de Compagnie druk uit te oefenen, hem ging ontbreken.

\section{De residenten na 1666.}

De twee residenten, die de koopman Danckert van der Straeten opvolgden, waren de onderkooplieden Jurriaen Propheet (1666-68) en Amelis de Valée (1668-70), over wie respectievelijk de gezanten Wagenaer en De Jongh gunstige rapporten hebben uitgebracht. Beiden stierven na 2 jaren in Japara.

Reeds Van der Straeten had als secunde de assistent Jacob Couper naast zich gekregen, welke dienaar der Compagnie zich tot de belangrijkste van alle Japarase residenten zou ontwikkelen. Over zijn levensloop deelt De Haan in Priangan I Personalia p. 202-05 een en ander mede. Van Schotse afkomst zijnde, werd deze Jacob Couper in 1641 of '42 te Edinburgh geboren. In 1663 blijkt hij soldaat bij de V.O.C. te zijn. Het volgende jaar is hij reeds assistent te Bantam, wordt in 1665 naar Batavia overgeplaatst en vervolgens als secunde naar Japara. Het duurde enige tijd, eer hij opviel, doch eind 1669 werd hij ineens tot onderkoopman bevorderd, de rang van boekhouder overslaande. $\mathrm{Na}$ De Valée's dood werd hij eerst waarnemend resident, daarna, bij resolutie van 22 mei 1671, opperhoofd in Japara. Het volgende jaar werd hij tot koopman bevorderd. Tot deze snelle promotie kan hebben 
meegewerkt, dat hij de „Javaanse tale prompt lesen, schrijven en spreken" kon.

Op 28 febr. 1676, tijdens een kort verblijf in Batavia, huwde hij de 18-jarige Aletta Brelius, dochter van ds. Theophilus Brelius. Daar zij hem naar Japara volgde, was zij de eerste Europese vrouw, die op Java's Oostkust verbleef.

Dat de Compagnie, niettegenstaande het vele onaangename, dat zij in die jaren juist te Japara ondervond, zeker niet van plan was spoedig heen te gaan, bewijst wel de algehele vernieuwing der loge, die onder Couper's bewind plaats vond. Deze grondige verbouwing wekte bij vele Javanen een diep wantrouwen. De muren zouden 1 vadem dik en 12 vadem hoog geweest zijn (D. 16 aug. 1672). De gouverneur kwam er zich persoonlijk van overtuigen, dat ze maar 6 duim dik en 3 vadem hoog waren (D. 19 sept. 1672). De voltooide loge kreeg zelfs prinselijk bezoek. Een jongere broeder van de kroonprins, pg. Demang, die met groot gevolg - 500 man - door Java reisde, kon zijn ongeduld nauwelijks bedwingen, om haar van onder tot boven te bekijken. Er was n.l. een verdieping op.

Van de aangeboden wijn, thee en sirih nam de prins niet veel, des te meer van opium en tabak (d. J. VI, 190).

Valentijn geeft van deze loge een plattegrond (IV, 29). Beneden was het pakhuis met de bottelarij, een kamertje voor de chirurgijn en een kamer voor twee assistenten. Boven woonde het opperhoofd, de secunde, en een assistent in aparte vertrekken.

Het is tijdens deze bekwaamste resident, die de factorij Japara ooit gehad heeft, dat de eens zo welvarende koopstad de prooi werd van een willekeur en een uitbuiting, die niet zonder een grote wanorde en machteloosheid in het binnenland denkbaar zijn.

De boze geest van al dit kwaad was de groot-sjabandar ng. WiraAtmaka. 


\title{
DE SJABANDAR WIRA-ATMAKA EN DE LANDREGENTEN.
}

\author{
Kj. Wira-Atmaka's ambt.
}

Toen de gouverneur Wira-Dika als ng. Wira-Dikara in 1669 opnieuw over Japara werd aangesteld, werd tegelijk kj. Wira-Atmaka tot grootsjabandar aldaar benoemd (D. 5 juli 1669). Tevens bekleedde deze dit ambt in Demak (D. 21 febr. 1670). Deze combinatie was blijkbaar niet ongewoon (D. 11 juni 1669), ook al ergerde de Demakse gouverneur er zich over. Maar ook, toen hij met het bestuur over Japara belast werd, hield hij het aan (D. $17 \mathrm{mrt} .1670$ ). Enige maanden kreeg hij zelfs het ,gouvernement van Lassum" er bij (D. 17 juni 1670).

Doch nu doet zich het merkwaardige voor, dat $\mathrm{kj}$. Wira-Atmaka, ofschoon over Japara aangesteld, toch nimmer echt gouverneur van deze plaats schijnt geweest te zijn, ook al wordt hij in de Nederlandse bronnen soms als zodanig gedoodverfd. Blijkbaar weifelde men.

In de eerste zijner zeven brieven, gericht aan de Hoge Regering, noemt hij zich ,gesonden om de stadt Japare en 8000 mannen te gouverneeren". Dit is omzichtig omschreven! Ook later beschrijft hij zich zo (D. 4 mei 1670).

Vast is zijn positie nog niet. Midden juni 1670 twijfelt de resident er aan, of hij zal aanblijven; hij kon wel eens door een voorganger, ng. Wangsa-Dipa, vervangen worden, om te Krawang voor de Sunan een stad te bouwen! (D. 17 juni 1670). Maar twee maanden later loopt het gerucht, dat de ,gewesen gouverneur Wierat Macka... opperste sabandar" zou worden van een onder vijf personen verdeeld gouvernement van Japara (D. 27 aug. 1670). Nauwelijks is dit geschied, of het gerucht loopt, dat kj. Wira-Atmaka als gouverneur zal hersteld worden. Zijn uit Mataram afkomende dienaren schijnen dit te bevestigen, daar zij verzekerden, dat hun meester aldaar tot „absoluyt gouverneur van Japara, en dat met meerder macht en auctoriteyt als voor desen" was aangesteld (D. 4 oct. 1670). Zelfs werd beweerd, dat hij als „opperste strantheer" in Mataram zou verblijven (D. 3 dec. 1670). Doch in maart 1671 was hij weer in Japara terug, zodat hij geen opperstrandheer zal 
geworden zijn (D. 28 mrt. 1671). Integendeel! Op 23 apr. 1671( D.) ontving de Hoge Regering weer een missive van $\mathrm{kj}$. Wira-Atmaka, thans „out-gouverneur van Japara... wien gelast was de coopstadt van Japara" te besturen.

In zijn vierde brief, ontvangen op 2 apr. 1672 (D.), heet hij voor het eerst ronduit "sjabandar tot Japara", evenzo in de vijfde (D. 22 apr. 1672), het laatst in zijn achtste (D. 29 nov. 1674). Ook de Hoge Regering begon hem nu zo te noemen, het eerst in een schrijven aan de resident (D. 27 apr. 1672), daarna in een officiële brief aan de kroonprins (D. 14 mei 1672). In een klacht over zijn monopoliseren van pluimvee en rijst, wordt verklaard, dat zo iets ,noyt voor desen by géén groot-gouverneur, laet staen een sabandaer wier gepleegt" (D. 23 oct. 1672). Kj. Wira-Atmaka is dus hoogstens als een groot-sjabandar te beschouwen.

Doch niet enkel het hoofd van Japara, ook de hoofden der overige drie voorname strandplaatsen heetten sjabandar, b.v. in D. 29 mrt. 1674: „keay Wirat Macka... nevens d'andere strandsabandars”, of: „Wirat Macka... nevens de sabandars van Samarang, Demacq en Javana", die dus samen staan voor de vroegere strandheren dier plaatsen. Afzonderlijk wordt genoemd de gouverneur Sabda-Carty van Djuwana, die „conings sjabandar" heet (Rembang 25 febr. 1671 K.A. 1173 f. 1348).

\section{De landregenten of umbuls.}

Terwijl de macht van Japara's hoofd een veer moest laten, traden naast hem nieuwe machthebbers, de landregenten, zoals de Compagnie hen noemde, of umbul's, zoals ze in het Javaans heetten, sterker op de voorgrond. Het waren er vier: Karti-Djaja, Ima-Reksa, Astra-Kara en Pringga-Watjana (Jap. 19 sept. 1670). Misschien begon hun invloed zich reeds na kj. Wira-Dika's eerste aftreden in 1667 te laten gelden.

Hun positie was sterk: zij weigerden gehoorzaamheid aan $\mathrm{kj}$. WiraAtmaka (Jap. 25 febr. 1671 d. J. VI, 195), want zij werden ,door de stathouders ten hove gesterckt". Met een sleep van 4 tot 500 mensen kwamen zij de loge bekijken en één hunner ging daarover ten hove verslag uitbrengen (D. 3 sept. 1672).

$\mathrm{Zij}$ stonden in scherpe oppositie tot $\mathrm{kj}$. Wira-Atmaka, die zo ,by alle regenten gehaet wiert" (D. 23 oct. 1672), dat men het einde van zijn gezag voorspelde. Een landregent kwam de resident in de loge verzoeken, „by aldien hem Wierat Macka overlastigh viel, hem te waerschouwen, dat hy dan sulcx soude voorcomen" (D. 25 oct. 1672).

Verh. dl. 33 
Ondertussen werd de invloed van de 3e Engelse zee-oorlog ook in het Oosten merkbaar. Nadat kj. Wira-Atmaka, met 1000 rds. omgekocht, oogluikend een eerste mislukte aanval der Nederlanders op het Engelse schip de „Zante” had toegestaan, beletten de landregenten, „die daerover reets met Wierat Macka in verschil" waren, een herhaling, zonder voorafgaande goedkeuring door het hof (D. $6 \mathrm{mrt}$. 1673). Een hunner, Wangsa-Prana, klaagde er zelfs in Mataram over (D. 23 apr. 1673), zodat volgens gerucht, $\mathrm{kj}$. Wira-Atmaka het niet lang meer zou maken.

Met diens zonen hadden de landregenten "questien ... tot dootslagen toe" (D. 1 oct. 1673). Eén zoon riep de tussenkomst van de resident Couper in, die deze weigerde, „onder pretext zylieden van beyde zyden onse vrunden waeren". De Hoge Regering verbood het ook ten strengste. Wel werkte de tijd kalmerend, maar over het gebruik van zeehaven en rivier bleef nog „al wat haspelingh”, hetgeen ook de Compagnie last bezorgde. In $1674 \mathrm{lag} \mathrm{kj}$. Wira-Atmaka door het aanhouden van alle vaartuigen en „ook selffs tot de wapenen toe seer hevig overhoop" met de landregenten (D. 6 dec. 1674). Dezen klaagden dan weer bij de Vorst. Zo ging het door tot het bittere einde toe.

\section{De umbuls elders.}

Doch niet alleen te Japara waren strandregenten of umbuls. In Samarang wordt begin sept. 1677 een Astra-Juda aangetroffen, „oemboel uit Samarang" (d. J. VII, 137). Speelman noemt hem in zijn instructie voor Is. de Saint Martin (d. J. VII, 200) een oud man, „wiens vader en vervolgens hy veele jaren agter malkander ombol of landregent in dit district geweest" zijn. Het is dus een reeds lang bestaand ambt; in Japara is het bijzondere, dat er na 1670 zulke grote bevoegdheden aan verleend zijn. Dat dit ook in Samarang het geval is geweest, ligt wel voor de hand, doch wordt niet bericht.

In Sura-Baja komen ze ook voor, elf in getal, en ze worden door Speelman in 1677 bij name genoemd (d. J. VII, 128). Vijf lopen naar de rebellen over en worden door vijf andere vervangen. Hun getal is dus vast. De overlevering kent voor Sura-Baja een tijd, dat de umbuls er de baas waren. Ook Speelman kent zulk een umbul-tijdperk (d. J. VII, 141). Schipper Jacob Croes van de "Zalm” ontmoet in 1672 te Sura-Baja: gouverneurs, hetgeen blijkbaar hetzelfde is.

Maar ook in Tuban kent men zulk een tijd van umbuls zonder bupati's. De Babad Tuban (p. 18) meldt, dat op Matarams bevel de 
bupati pg. Anom na een bewind van 12 jaren geschorst werd; daarna werden slechts umbul's aangesteld, n.l.

1. Wongsa-Pradja in het district Djenu,

2. Wongsa-Ita in het district Gesik,

3. Wongsa-Tjakra in het district Kidul-Ngardi,

4. Juda-Patra in het district Singgahan.

Daarná werden weer bupati's benoemd. Over de aanstelling van een sjabandar wordt niets gemeld, doch deze zal in een havenplaats zeker niet ontbroken hebben.

In Lasem worden „regenten” gevonden, wier afwezigheid - ze zijn in Mataram - het zaken doen belemmert (D. 23 apr. 1671). Ook dit kunnen umbul's geweest zijn.

Een en ander maakt het waarschijnlijk, dat het optreden der umbul's meer is geweest dan een plaatselijk verschijnsel, doch zich langs de gehele kust zal hebben voorgedaan. De bedoeling kan moeilijk anders geweest zijn, dan het breidelen van de macht der rijke strandheren, door hen slechts met de sjabandarij te belasten, onder toezicht van en in evenwicht gehouden door deze landregenten of umbul's.

Het is mogelijk, dat dit op de voorgrond plaatsen der umbuls in het midden van 1670 heeft plaats gevonden, daar op 21 sept. 1670 uit Japara gemeld werd, dat de Sunan ,dagelycx besich (was) met syne lant- en strantregenten, die hy d'eene afsette en d'andere weder in de plaetse stelde" (D. 26 sept. 1670).

Het resultaat zal vergelijkbaar zijn geweest met de toestand, bestaande toen de gouverneur van Japara een deel zijner bevoegdheden, verplichtingen en inkomsten aan de regerende kooplieden moest afstaan. Thans waren de rollen omgekeerd. Een éénhoofdig bestuur, de sjabandar, nam het werk der regerende kooplieden waar, terwijl de gouverneur door een aantal umbuls of landregenten vervangen was.

Wat was nu het werk van deze sjabandar?

Kj. Wira-Atmaka"s geldbeheer. 1669-76.

$\mathrm{Kj}$. Wira-Atmaka's bemoeienissen waren goeddeels van financiële aard. Reeds bij zijn aanstelling tot groot-sjabandar stond hij in voor een jaarlijks geschenk der Compagnie van 10.000 rds. (D. 5 juli 1669), terwijl, gelijk wij zagen, zijn zoon, kențol Djaja-Suta afrekening vorderde van de tol sedert het bewind van de tumenggung Mataram in 1663. Hij was druk bezig met de ,middelen van den Sousouhounangh in te samelen" (D. 17 mrt. 1670). Zelfs wilde hij een Japarase factorij in 
Batavia stichten, „opdat wy door mynen handel connen weten, dat Batavia en Japare één is". Het was hem gelast, en zonder medewerking der Compagnie zou zijn werk mislukken. Voorts vroeg hij zeebrieven om te handelen met rijst, zout en peper op Baros, Priaman, Atjeh, Queda, Perak en Oedjangsalang. Als ,geschenk” bood hij rijst, kandijen poedersuiker aan (D. 4 mei 1670).

De factorij op Batavia werd toegestaan, het varen naar de genoemde plaatsen wegens de oorlog ontraden (D. 3 juni 1670). De aangeboden slechte suiker en ondeugdelijke rijst konden niet worden aangenomen, „wel voornamentlyck om het quaet gevolg".

Het volgende jaar kwam hij op een zeepas naar Baros terug (D. 6 apr. 1671), doch ofschoon de resident die voor hem verzocht, „dewyl ... de Compagnie seer toegedaen" was, werd zij voorlopig geweigerd (D. 9 apr. 1671). Ook passen voor Priaman en Baros werden verzocht, daar hij last had, om "met des Sousouhounangs middelen te negotieeren” (D. 23 apr. 1671). De zeebrief voor Priaman werd toegestaan, die voor Baros ontzegd, wegens te verwachten moeilijkheden (D. 8 mei 1671).

Voorts deelde hij mede, dat tijdens zijn verblijf te Demak een maulana (Moslims geleerde?) enige middelen van hem meegenomen had. Na zijn overplaatsing had hij deze nog 500 rds. toevertrouwd. $\mathrm{Nu}$ waren bij een proces tegen iemand van Koromandel alle goederen van genoemde maulana te Malaka in beslag genomen. Daarom zou hij die maulana graag in Demak willen zien, daar de sjabandar van Demak alle zaken tussen de maulana en de Kling hangende kende (D. 23 apr. 1671). De Hoge Regering daagde echter beide partijen voor de rechtbank te Batavia (D. 8 mei 1671).

$\mathrm{Kj}$. Wira-Atmaka handelde ook in kleden. Een partij nam hij tegen redelijke prijs van de resident over, doch zette die "ten eersten aen de Mataramse coopluyden” om (D. 27 juni 1671), zodat de ,swarte Deen" 1 met de zijne zou blijven zitten.

Hij bood nu 100 pikols was aan tegen 30 rds. het pikol, half kleden, half geld, waarop de Hoge Regering inging, ,als 't maer suyvere specie is, daerop gelet dient" (D. 29 juli 1671).

Sedert 2 apr. 1672 verschenen in het Dagregister zijn menigvuldige klachten over de erfenis van Imbassadana, die de stemming in de volgende jaren volledig zou bederven (D.). Deze kwestie zal afzonderlijk worden behandeld.

1 Een inheemse agent der Denen? Vgl. Joh. Brøndsted, Vore gamle Tropekolonier I, 88. 
Zijn rijkdom bracht hem in moeilijkheden met het Hof, dat hij lang wist te sussen. Straf voor willekeur tegen Bataviase burgers, wier hout hij tot twee maal toe in beslag genomen en pas na een geschenk teruggegeven had, vreesde hij niet, ronduit verklarende: „de Mataramse grooten waren kalen adel en die hy altydt met geldt kon tot vrunden maecken en tevreden stellen" (D. 23 apr. 1673). Hij had nu een kapitaal van 13 tot 14.000 rds. bij elkaar geroofd, ,daermede (hij) de groote aen de Mataram soo soetjes wist af te vieren, in den arm te nemen en syn credit alsoo staende te houden, alsoo het anders onmogelyck was, dat hy het disrespect, aen de afgekome Mataramse hofgesanten betoont, soude konnen verantwoorden" (D. 29 apr. 1673).

Enige maanden later was de ,geroofde buyt" reeds tot $20.000 \mathrm{rds}$. gestegen, „om daermede syn accoort te maecken” (D. 21 juni 1673). Aan de Denen was hij 4000 rds. schuldig en wenste zonder te betalen naar boven te gaan. Maar de Deense resident had dit kunnen voorkomen en daarna zijn eigen kleden en opium weer terug ontvangen.

Wij zien dus, dat $\mathrm{kj}$. Wira-Atmaka zich inderdaad vaak met handelszaken bezig hield, doch dat zeker sommige dier zaken een bedenkelijk karakter droegen. Dat hij zich liet omkopen toont o.a. de geschiedenis van het zeegevecht op Japara's rede.

\section{Het geval met de Engelse „Zante”. 1673-74.}

Begin nov. 1672 had de tijding van de derde Engelse zeeoorlog Indië bereikt. Op 19 jan. 1673 verscheen op Japara's rede het Engelse fregat „Zante”, bij de Nederlanders bekend als het jacht de „Saent”, tellende 30 koppen en 20 tot 24 stukken. Nadat de toestemming van de gouverneur $\mathrm{kj}$. Wira-Atmaka tegen 1000 rds. verkregen was, vielen het Nederlandse jacht de "Stompneus" en twee sloepen de Engelsman aan. De gevolgen waren noodlottig! De Engelsen gaven flink vuur en boorden de "Stompneus" in de grond. Het schip zonk in ondiep water, bijna de gehele lading ging verloren, terwijl de Javanen van het tegen de kant zittende jacht stalen als de raven. De Nederlanders wilden revanche nemen, doch $\mathrm{kj}$. Wira-Atmaka weigerde verlof tot een tweede gevecht op de rede. De „Zante”, door de Nederlanders geblokkeerd, waagde zich niet in volle zee. Maanden verliepen met onderhandelen. $\mathrm{Kj}$. WiraAtmaka, zakenman als hij was, wilde de Engelse kapitein Andrew Parrack of Parrick 500 rds. voor de genoten gastvrijheid laten betalen, doch deze weigerde hardnekkig, ook toen zijn positie steeds hachelijker 
werd. In Japara heersten namelijk ziekten, die naar het geblokkeerde schip oversloegen. Drie tot vier man stierven, zelfs de kapitein werd ziek. Zijn toestand werd zo ernstig, dat de Engelsen de Hollanders om een chirurgijn verzochten, "'t welck hun absoluyt afgeslagen" werd. Inderdaad weinig menslievend! $\mathrm{Na}$ de dood van hun schipper sprong de Engelse bemanning uit de band. Reeds lang hadden ze geen gage ontvangen en ze wilden daarom de schuit aan de Nederlanders verkopen. De Engelse boekhouder deed wat hij kon; dan verkocht hij het schip liever aan de Javanen, maar die boden te weinig. Voordat de Nederlanders, door bemiddeling van pg. Adipati Anom, de kroonprins, er in geslaagd waren toestemming tot een tweede aanval te krijgen, hadden de Engelsen reeds de „Zante” voor 3200 rds., dus met groot verlies, aan de Bantamse sultan verkocht. Ruim een jaar, nadat zij ter rede van Japara verschenen was, voer de „Zante” met een Javaanse en Moorse bemanning naar Bantam; daarna werd het schip Mekkavaarder (D. 1673-74 passim). Over de financiële afwikkeling dezer affaire is in Londen nog heel wat te doen geweest (A Calendar of the Court Minutes etc. of the E.I.Comp. 1674-1676 passim).

Het nieuws over het noodjaar 1672, met zijn oorlog tegen Frankrijk en Engeland, kon de Javanen dus niet ontgaan. Het kwam zelfs de kroonprins ter ore (D. 4 oct. 1673), tegelijk met een bestelde trompet. Mogelijk omdat hij het nauwelijks kon geloven, liet hij bij de sultan van Bantam vragen, of het wel waar was. Ook had hij de Sunan over deze oorlog ingelicht, alsmede over het gevecht met de „Saent". De Vorst zou daarop de Engelsman hebben willen ontbieden, doch de kroonprins zou zich voor de Susuhunan ,vernedert en geseyt" hebben, dat hij de Engelsman niet geliefde te roepen, maar op zee te laten blijven, om eerst de Gouverneur-Generaal daarover te horen.

Deze liet zijn havenmeester schrijven, dat hij liever zijn vader diende te bewegen, zijn toestemming tot een gevecht op Japara's rede te geven (D. 15 nov. 1673). Antwoord op dit verzoek bleef uit.

Intussen is het merkwaardig, dat het bericht over de antagonie tussen Nederlanders aan de ene zijde, en Engelsen en Fransen aan de andere een zekere neerslag in de Javaanse overlevering heeft gevonden, n.l. in het verhaal over de Inggris en Prasman, die de gouverneur van Japara zouden geholpen hebben bij het verdrijven der Makassaren (Babad Meinsma 187). Daar deze verdrijving pas enige jaren ná het rampjaar plaatsvond, dient deze episode in een ander verband besproken te worden. 
De kwestie Imbassadana. 1672--75.

Van 1672 tot 1675 is de verhouding tussen de Compagnie en de Javanen ten sterkste beïnvloed door de kwestie van de geschoren Chinees Imbassadana, vermoedelijk een Moslim.

Deze komt sedert het einde van 1668 als sjabandar te Japara voor (D. 19 nov. 1668), doch hij bekleedt dit ambt tevens in Demak (D. 19 sept. 1669), denkelijk alleen voor wat de tollen der Chinezen betreft. Ondernemingslust ontbreekt hem niet. Hij levert de Compagnie een te Demak gebouwd jacht (D. 19 nov., 26 nov. 1668, 20 mei 1669). Een schuld daarop lost hij aan de resident met suiker af. Ook biedt hij aan voor de Oosterse provinciën anijs en arak te branden, een derde goedkoper dan in Batavia, op welk aanbod de Hoge Regering niet ingaat (D. 30 jan. 1669). Tevens helpt hij de Compagnie aan zout, waarvoor de gezant De Jongh hem met een ,silverdraets doosje” beloont (D. 5 juli, 18 oct. 1669). Ook van minder oirbare dingen wordt hij beticht. In 1671 had de kroonprins hem doen vatten en binden, zo mede al zijn middelen aanslaan, op beschuldiging, dat hij voor 300 realen enige Javanen had omgekocht, ten einde een Chinees te doen verdwijnen (d. J. VI, 186). Een jaar later blijkt hij met de jonk van de Bataviase Chinees Honcqua een reis naar Japan te hebben gemaakt (D. 15 apr., 14 mei en 27 sept. 1672), doch onderweg of te Batavia is hij overleden. Daarom werd bij aankomst aldaar op schip en rijke lading beslag gelegd.

Achteraf blijken velen aandeel in de lading te hebben gehad en de eerste, die er aanspraak op maakte was $\mathrm{kj}$. Wira-Atmaka, daar ,'t ingeladene des Conings goederen" waren (D. 2 apr. 1672). Doch ook pg. Adipati Anom bleek voor duizenden (4000) rijksdaalders aan goederen te hebben meegegeven (D. 15 apr., 29 juni 1672). Van de gouverneur van Demak, die er zijn dochter njai Gedé voor naar Batavia zond, had Imbassadana zelfs voor $115573 / 4$ rds. meegenomen (D. 9 mei, 7 nov. 1672). Bovendien maakten nog een steeds groeiend aantal Bataviase ingezetenen aanspraak op een aandeel (D. 14 mei, 29 juni 1672). Onderling waren de eisers het natuurlijk oneens, b.v. de kroonprins en de Japarase gouverneur, terwijl in Japara zelfs beweerd werd, dat twee Chinezen in Batavia voor 500 rupiah waren omgekocht, ten einde een valse eed af te leggen (D. 10 aug. 1672).

Om meer indruk te maken zond $\mathrm{kj}$. Wira-Karti Imbassadana's weduwe, kind en broeder, begeleid door 17 lurah's naar Batavia (D. 30 aug. 1672). Imbassadana, zo schreef hij, was zijn onderdaan geweest. 
Kj. Wira-Atmaka liet zelfs Jacob Couper bij alle rijke Chinezen in Japara rondgaan om na te vragen, wiens goederen in de bedoelde jonk geladen waren en allen tekenden, dat ze van $\mathrm{kj}$. Wira-Atmaka afkomstig waren (D. 11 sept. 1672).

Intussen had het proces in Batavia zijn voortgang. De Raad van Justitie oordeelde, dat de helft van de opbrengst aan Thong Honqua toekwam (D. 14 sept. 1672). Het was zelfs met de stukken te bewijzen, zodat dit voor de sjabandar Mirma-Gati, die kj. Wira-Atmaka naar Batavia zond, wel geen aangename verrassing zou wezen. Het was daarom geraden in Japara al vast de kostbaarste bezittingen aan boord te brengen, met het oog op vergeldingsmaatregelen. Terecht, want $\mathrm{kj}$. Wira-Atmaka begon te dreigen (D. 19 sept. 1672). Als hij het geld, dat van de Sunan was, niet kreeg, zou hij het halen, waar hij maar kon. $\mathrm{Hij}$ verzocht slechts recht, en zou insgelijks recht doen. Als de zaak in 2-3 maanden niet afgedaan was, zou hij wel aan zijn ,guarant" komen.

Ten slotte deed op 28 sept. 1672 de achtbare Raad van Justitie definitief uitspraak (D. 27 sept. 1672). De uitslag moet voor belanghebbenden teleurstellend geweest zijn, daar hevige reacties in Japara gevreesd werden (D. 27 oct. 1672).

Om Wira-Atmaka's geweldenarijen te beëindigen, besloot de Hoge Regering een „somma van 7000 rds., noch onder boedelmeesters synde, te projecteren om aen hem uyt te laten keeren, ofte aen degenen, die by speciale acte van den Sousouhounangh daertoe sal worden gerechtight" (D. 2 mei 1673). Dit zou hem en pg. Adipati Anom bekend gemaakt worden, „om ons buyten haer questie te houden" (D. 4 mei 1673), hoewel Couper kj. Wira-Atmaka's zaak de meest gerechtigde achtte. Eisers dienden quitanties over te leggen (D. 20 mei 1673).

$\mathrm{Nu}$ konden of wilden de Javanen geen bewijsstukken overleggen. Keer op keer beweerden zij, dat het niet de gewoonte van de Sunan was, er zulke op na te houden (D. 6 juni 1673). Een groot Javaans gezantschap werd aangekondigd, om het geld in te vorderen (D. 7 sept., 29 sept., 11 nov. 1673). Ten Kastele wilde men ten slotte wel met een „chiap of teecken van den grooten Sousouhounangh" genoegen nemen (D. 15 nov. 1673).

Doch zelfs dit eenvoudige bewijs van de Vorst, ,aen wien deselve penningen meest geregtigt ende uytgekeert mosten werden", bleef uit (D. 16 nov. 1673). Het bleef bij uitvoerige, maar stellige beweringen van $\mathrm{kj}$. Wira-Atmaka, dat „Imbassadana het geld van den Sousouhounangh onder hem gehad heeft". Van andere dan Javaanse aanspraken 
wist hij niets, ,want alle het geld, dat Imbassadana gehad heeft, behoort alle op Japare" (D. 29 nov. 1674). Maar de resident zeide hem, dat hij van een bezending "sonder bewys des Sousouhounangs, niets hadde te verwachten" (D. 6 dec. 1674). Er hadden zich al zoveel pretendenten voorgedaan, o.a. de kroonprins zelf, „,alle sonder bewysen”, slechts „voorsien van een blooten eys", waarop de rechters geen behoorlijk vonnis konden vellen. Daarom werd nogmaals een ,waarachtig teeken van den Sousouhounang" gevraagd (D. 15 dec. 1674).

Een voorstel om aan de armlastige weduwe van Imbassadana iets uit te keren, kon niet in aanmerking komen (D. 24 dec. 1674), ook al kwam het van de tg. Mataram Sura-Wangsa (D. 10 jan. 1675). De medepretendent Wira-Karti was intussen al om hals gebracht (D. 20 apr. 1675).

Het laatst horen wij van de kwestie Imbassadana in mei 1675, toen kj. Wira-Atmaka er nogmaals de van verlof uit Batavia teruggekeerde Jacob Couper mee lastig viel en een bezending naar de Hoge Regering in het vooruitzicht stelde, "dewyl het onmogelyk en ook geen Javaanse manier en was, om een teeken van den Sousouhounangh te krygen" (D. 31 mei 1675).

Deze bezending is nooit in Batavia verschenen; het volgende jaar verdween $\mathrm{kj}$. Wira-Atmaka uit Japara en hielden belangrijker zaken de geesten bezig dan een geldvordering.

Het is te begrijpen, dat kj. Wira-Atmaka de Compagnie haar vasthouden aan de formele eis van een schriftelijk bewijs zeer kwalijk genomen heeft, waaruit zijn verbittering en ruw optreden te verklaren zijn.

\section{Kj. Wira-Atmaka's wanbeheer.}

Naar mate het proces over de nalatenschap van Imbassadana zijn einde naderde, werd kj. Wira-Atmaka minder meegaand, en niet slechts tegenover de Nederlanders, die hij, uit vrees, nog ontzag.

Zijn dienaren begonnen de in- en uitvoer der koopwaren te hinderen, doch hij toonde zich uiterlijk nog een vriend der Compagnie (D. 3 oct. 1672). Hij beweerde ,syn guarant van de Bataviase Chineesen wel” te zullen krijgen. Gaandeweg werd zijn humeur slechter. Op 15 oct. 1672 wordt gemeld, dat kj. Wira-Atmaka ,wacker in grasduynen had gegaen". De Deen (vgl. D. 27 juni 1671) en een Chinees waren ten huize van de Chinese sjabandar handgemeen geweest en veel volk was toegestroomd. De Deen was toen gevat, gebonden en ergerlijk mishandeld, en 
„soodanigh in 't hoenderhock gebraght". Pas op voorbede van de resident en borgstelling van de Chinese sjabandar was hij eruit geraakt. Maar de volgende dag liet $\mathrm{kj}$. Wira-Atmaka alle goederen van de Deen wegnemen, „maer de Deen om sigh te verantwoorden daer comende, hadt kinnebackslagen in ' $t$ aensien des gouverneurs ... van syne dienaren gekregen".

Voorts beval Wira-Atmaka om het huis van een Moor in beslag te nemen en deze zelf te binden. De Moor echter, dit voorziende, was naar de resident in de loge gesneld, had een voetval gedaan en verklaard niet het minste misdreven te hebben. Alleen had hij een paar kleden van de Deense factor gekocht, die ze met al diens goederen wilden in beslag nemen. Hij werd ervan beticht, de Deen bij het binnensmokkelen van goederen geholpen te hebben.

Daarop was Couper met de arme Moor naar de plaats van opwachting van $\mathrm{kj}$. Wira-Atmaka gegaan. Hij vond deze daar gezeten, met de boomwachters gebonden voor zich op de grond, ,als een beseten mensch". Zonder ergens naar te luisteren liet hij de Moor met nog iemand, die bij hem was, binden en door zijn dienaren flink afrossen, ,en stont terstont ook op en sloegh selffs een der gebondene, totdat hy moede was, wanneer 't selve syn dienaren wederom hervatten". De resident kon het niet langer aanzien en vertrok naar de loge (D. 20 oct. 1672).

Een matroos, van het binnensmokkelen van gestolen buskruit beschuldigd, was eveneens gevat. Couper met de schipper en boekhouder trokken weer naar de paseban, waar de gouverneur zich niet vertoonde.

Hij liet echter boodschappen, dat men de gestolen kardoesen en het kruit aan het opperhoofd zou overgeven. Om zijn goede wil te tonen, had Couper toen de matroos doen "leersen” en geboeid naar Batavia gezonden.

Ook zijn ondergeschikte, de ondersjabandar Mirma-Gati, kreeg er van langs bij zijn terugkomst uit Batavia op 14 oct. 1672. Hij liet de resident door deze vragen, ,waerom syn gelt niet van Batavia quam" en zat ,als een beseten mensch op de binnen-pasebaen..., ydereen sonder eenige de mintse reden uytscheldende en slaende".

Een door hem ingevoerd monopolie van kippen en rijst wekte de haat van alle regenten op (D. 23 oct. 1672). "'t Was onlydelyck voor de arme ingesetenen", maar tegenover Couper toonde hij zich toen weer vriendelijk.

Op 10 nov. 1672 schreef de resident, dat ,de uytsinnige Wira Macka” de Compagnie overal de voet dwars poogde te zetten, o.a. bij de tol. 
Hij had twee Chinezen „uyt eenige opgeraepte pretentiën geruyneert”, reden waarom enige anderen ,sonder adieu te seggen, verhuyst" waren; „de huyrlingen van de (Chinese) suykerleveraers had hy haer buffels affgenomen". Daardoor kon van die zoetigheid niets meer worden afgebracht en was een fluit met een halve lading vertrokken (D. 23 nov. 1672). Toch achtte hij zich de vermoorde onschuld. Na een militaire tegenvaller der Nederlanders verklaarde hij: „Het en can die niet wel gaen, die my ongelyck doen" (D. 8 dec. 1672).

Meer dan eens liet hij Bataviase burgers van hun houtwerken beroven, die zij pas na een geschenk terugkregen; de resident mocht er zich niet mee bemoeien. De Mataramse groten kon hij wel sussen (D. 3 apr. 1673). Couper vertierde liever kleden in Samarang dan in Japara, ,alsoo onder Wirat Macka niet goets voor de Compe. uyt te reghten was". De gezagvoerder van een Deens jacht dacht er al net zo over (D. 8 mei 1672).

Ondertussen bleef hij ,met syn creaturen in de woeste regeringen en 't onderdrucken der ingesetenen noch al continueeren, 't welck de negotie tot Japara seer dede vervallen" (D. 29 apr. 1673); klagen was vruchteloos, daar het hem niet kon schelen, „wie hy oock affronteerde". Door omkoperij won hij het hof voor zich, ,alsoo het anders onmogelyck was, dat hy het disrespect aen de afgekome Mataramse hofgesanten betoont, soude konnen verantwoorden". Van de klachten der landregenten aan het hof trok hij zich niets aan (D. 9 mei 1673). Couper sprak daarom van de "half in 't wilt loopende Javaense regeringe" (D. 21 juni 1673).

\section{Kj. Wira-Atmaka's hofreizen.}

Jaarlijks heeft $\mathrm{kj}$. Wira-Atmaka aan het hof vertoefd, uitgezonderd in 1672. Van zijn laatste verblijf in 1675 is hij niet meer teruggekeerd; het volgende voorjaar bleek hij door ng. Wangsa-Dipa te zijn vervangen. Van deze hofreizen volgt hier een overzicht.

\section{De eerste hofreis.}

Eind juni 1670 waren al de vier strandheren naar Mataram ontboden, om gelijk kj. Wira-Atmaka meende, over een gezant naar Batavia te spreken (D. 1 juni 1670), welk plan spoedig vervaagde. Hoewel het lang duurde, eer hij in gehoor werd ontvangen, sprak men al spoedig over zijn stijgende invloed. Vóór $22 \mathrm{mrt} .1671$ was hij weer in Japara terug (D. $29 \mathrm{mrt} .1671$ ). 
De tweede hofreis.

Op 8 juni 1671 trok de gouverneur met andere strandheren weer naar Mataram (D. 17 juli 1671). Dit keer werd hij dadelijk en herhaaldelijk opnieuw door de Sunan ontvangen (Japara 20 aug. 1671). Begin 1672 was hij weer in Japara terug (D. 2 apr. 1672).

De zaak-Imbassadana zal in 1672 zijn hofreis belet hebben.

\section{De derde hofreis.}

Toen kj. Wira-Atmaka op 3 juni 1673 uit Japara vertrok (D. 6 juni 1673), met medeneming van was, kleden en dgl., zou hij, ,na yders meeninge ... niet ligt wederkeeren ... om de generale haet der grooten". Met de andere strandheren reisde hij naar boven (D. 14 juni 1673), ook al liepen er geruchten, dat hij onderweg „,door last der hofsgrooten van al syn goet stondt geplundert en selfs de rest gegeven te worden" (D. 17 juni 1673). Pg. Adipati Anom had al verzekerd, dat deze kj. Wira-Atmaka de Sunan en zijn rijk ,soght te bederven”. Zijn dood zou een grote schrik onder de strandheren baren.

Maar kj. Wira-Atmaka had voorzorgsmaatregelen getroffen. Hij sleepte een ,geroofde buyt van 20 duysent rds." mede, „om daermede syn accoort te maecken". De blijde tijding van een Deense schenkage redde, volgens sommigen, zijn leven, ook al was zijn gedrag tegenover de Deen juist „gansch niet civiel, maer ongerymt” (D. 21 juni 1673). „Men rugte nu, dat Wirat Macka eerstdaeghs het Japaerse gouvernement met meerder aensien... stont te komen bekleeden" (D. 23 juli 1673).

Ten hove had hij ook vele beschuldigingen op zijn zoon Djaja-Suta geschoven (D. 1 aug. 1673).

Inderdaad kwam uit Mataram tijding, dat $\mathrm{kj}$. Wira-Atmaka door de Sunan opnieuw met het gezag over Japara en nog 1000 man uit de landregering begiftigd was (D. 5 aug. 1673). Dat de Sunan hem, tegen zijn gewoonte, had uitgescholden, deerde hem niet (Japara 13 sept. 1673). Op 20 sept. 1673 kwam de ondersjabandar kj. Mirma-Gati weer thuis, ,dapper swetsende over syn meester Wirat-Macka's bekome groot ontsagh" (D. 29 sept. 1673).

Eindelijk daagde hij zelf op 26 dec. 1673 weer op (D. 29 mrt. 1674) en toonde zich heel vriendelijk. Belangstellend had hij ,na den staet des oorlogs als onses vaderlands gevraegt". De hem gestelde financiële eisen waren echter niet verlicht, integendeel. 
De vierde hofreis.

Op 27 mrt. 1674 stond Wira-Atmaka weer op vertrek naar Mataram (D. 3 apr. 1674). Blijkbaar genoot hij nog de gunst van zijn Vorst. Spoedig zou hij immers als gezant naar Batavia gaan, daar het eertijds gezonden paard oud begon te worden en de Sunan ook weer een diamant verlangde, zoals hij er vroeger een van Van Goens gekregen had.

Maar spoedig deden somberder geruchten de ronde. $\mathrm{Kj}$. Wira-Atmaka zou op bevel van de Sunan om het leven zijn gebracht (D. 10 mei 1674). Ten minste werd hij dagelijks om 10.000 rds. hard gemaand (D. 10 mei 1674). „Van de strandgouverneurs stondt het na de geruchten een aen ' $t$ hoff 't leven te kosten ende 't welk naer apparentie op Wirat Macka soude uytdraejen” (D. 11 juni 1674). Maar hij hield vol: „Wirat Macka bleef noch al ten hove ende, schoon er diverse klagten over hem als syn soons moedwilligheden voorquamen, echter noch in syn volle commando ende sabandars regeringe continuëren (D. 10 oct. 1674). Dagelijks werd hij terug verwacht (D. 21 oct. 1674).

Eindelijk was hij in Demak terug gekomen, om er het graf zijner moeder te bezoeken (D. 16 nov. 1674), doch zijn afreis uit Mataram was „ter sluyk" geweest, zodat hij wel niet lang zich in de Japarase regering zou handhaven. Vóór 2 dec. 1674 was hij weer in Japara terug, was met ,syn oude onhebbelikheden aengevangen ende (had) met de landregenten door 't arresteren aller vaertuygen ende ook selffs tot de wapenen toe seer hevig overhoop gelegen" (D. 6 dec. 1674).

\section{De vijfde hofreis.}

Op 25 mei 1675 was kj. Wira-Atmaka nog in Japara (D. 31 mei 1675), doch op 7 juni d.a.v. niet meer (D. 19 juni 1675). Hij werd echter niet dadelijk voor de Sunan ontboden (D. 24 juni 1675). Mirma-Gati, de landregent Wangsa-Prana e.a. hadden hem aangeklaagd, en de Sunan was er seer ,vergramt” over. Het einde bleef onzeker. Hij zou al wcer om zijn Demakse tollen gemaand zijn (D. 18 aug. 1674), werd om 40.000 achterstallige rds. aangehouden (D. 30 nov. 1675). Zijn dienaren waren wegens het kopen van, gestolen buscruyt uyt des Sousouhounanghs packhuysen vastgeseth en hy daerover vry suspect gewcrden". Het begon er somber voor $\mathrm{kj}$. Wira-Atmaka uit te zien.

„Wirat Macka's saeken ten hove scheenen noch al van quaden uytslach te sullen wesen, en had een radin Waja Coesoema, locra des Sousouhounangs lyfwacht, in stilheyt affgecomen, allomme en oock by 
onsen resident nae Wirat Macka's vorigh gedoente scherpelyck vernomen" (D. 29 jan. 1676).

Ten slotte brak de kruik tegen het einde van 1675. „Na 't langh suchten der Japaerse ingesetenen... had de Sousouhounangh nu eyndelyk eenen keey Angabey Wangsa Diepa 't Japaers gouverno opgedragen" (D. 10 apr. 1676). Deze had Wira-Atmaka bij zich, en liet diens zoons kențol Djaja-Suta en Karti-Taruna in de gevangenis werpen, om rekening en verantwoording van des Sunans middelen af te leggen. $\mathrm{Zij}$ zouden wel 44.000 rds. ten achter zijn. Aldus eindigde Wira-Atmaka's avontuurlijke loopbaan in Japara.

Daar tijdens zijn afwezigheid ten hove zijn ambt door zijn beide zonen werd waargenomen, dienen wij thans een blik op het gedrag dezer jongelieden te slaan.

\section{Kj. Wira-Atmaka's zonen.}

De zonen van kj. Wira-Atmaka, de kențols Djaja-Suta en Suta- (of Karti-) Taruna, deden voor hun vader in bandeloosheid niet onder.

Tijdens zijn hofreis van 1673 had hij het bewind aan de oudste, de „deugniet” kențol Djaja-Suta en de ondersjabandar kj. Mirma-Gati overgelaten (D. 14 juni 1673). Van de hachelijke positie zijns vaders was bij diens ,trotse regeringe" niets te bemerken (D. 22 juli 1673). De vader schoof de schuld der wantoestanden op zoonlief, die daarvoor opgeroepen werd. Deze verschool zich, wat hem het leven kon kosten, doch hij ontkwam (D. 1 aug. 1673).

Met de landregenten hadden de zoons voortdurend „questiën ... tot dootslagen toe" (D. 1 oct. 1673). Bij nacht hadden de knapen zeker „welgestelt Chinees... sonder de minste oorsaeck schielyck overvallen en van al syn middelen berooft" (D. 4 oct. 1673).

Tijdens de volgende hofreis verbeterde dit niet, daar zij „onderwylen noch soo onverdraegelycke regeringe leyden, dat vele inwoonders gedrongen wierden, haer goederen in 's Compagnies logie ende elders te salveren", gelijk zelfs de onder-sjabandar Mirma-Gati om persoonlijke bescherming verzocht (Japara 7 apr. 1674 d. J. VI, 189). Doch toen een prins van den bloede, pg. Demang, Japara bezocht, namen de deugnieten de wijk op zee, hetgeen de pangéran zeer mishaagde.

Gedurende Wira-Atmaka's laatste hofreis bereikte hun boosheid haar toppunt. Kențol Djaja-Suta had zich „,byna publicq” aan zeeroof schuldig gemaakt. Begin juni 1675 was hij onder schijn van een pleziertochtje naar Samarang vertrokken en ,met drie vaertuygen met een 
goede roof van onbekende cleden en andere coopmanschappen in één nagt weder thuys gekeert" (D. 19 juni 1675). Geen wonder, dat de „stadt Japara van alle coopluyden herwaerts en derwaerts wiert geschuwt en byna tot een wildernisse quam te geraaken" (D. 24 juni 1675). De resident besloot daarom 22 pas ontvangen pakken kleden te Samarang om te zetten en niet meer te Japara, ,dewyl er uyt de heylloose uytgelaten boosheyt en roveryen van kentol d'Jasouta niemant meer... derfde komen negotiëren" (D. 11 sept. 1675). Ten slotte vluchtte hij met zijn vrouw naar onbekende bestemming; de jongste zoon bleef echter „syn quade regeerplaets noch al . . becleeden” (D. 29 sept. 1675).

Pas begin 1676 dook hij weer in Japara op, om terstond met zijn jongere broeder in de gevangenis te verdwijnen (D. 10 apr. 1676).

Dit was het einde ener familie van financiële en politieke avonturiers, wier wandaden slechts zo lang ongestraft konden blijven, omdat zij vielen tijdens de laatste ellendige regeringsjaren van de Susuhunan, berucht als Mangku-Rat Tegal-Wangi.

\section{Samenvatting.}

Des Sunans verhouding tot de Compagnie overziende, merkt men op, dat de rol der strandheren daarbij niet kan weggedacht worden.

$\mathrm{Na} 18$ jaar oorlog met Batavia wensten de Javanen weer een goede verstandhouding met de Nederlanders, omdat zij daarvan profijt verwachtten; zelfs wilden zij weer een loge in de havenstad Japara toelaten. De Sunan hoopte daarvan evenveel voordeel te genieten als zijn strandgouverneurs. Verdienden zij wèl en hij niet, dan zou dit een achteruitgang van zijn macht en aanzien betekenen, een vooruitgang van de hunne. Aan de juiste belangenverdeling tussen de Vorst en zijn strandheren heeft het steeds gehaperd. De gouverneurs, op vier tot vijf dagen reizens van de Kraton verwijderd, werden ervan verdacht aan de vreemdelingen te veel te verdienen, ten minste daarvan te weinig aan het hof af te dragen.

Vóór 1648 bezit Japara een rijstmonopolie - een erfenis van de oorlogstoestand? Daarin komt verandering: elke haven mag zijn eigen rijst uitvoeren en vertollen. Met de stichting van de factorij te Japara - op verzoek van de Sunan! - rijzen moeilijkheden. Ook al brengen de Nederlanders de Vorst bijna jaarlijks hulde en geschenken, toch vindt hij, dat ze te grote winsten maken, terwijl zijn strandheren er àl te wel bij varen.

Vandaar een ommekeer omstreeks 1652: een handelscontrole, uitge- 
oefend door de kjai's Wira en Wira-Djaja, die daartoe tugurs aan de kust hebben. Of dit veel helpt? Men krijgt de indruk, dat met name de Chinezen en de Bataviase burgers zich er weinig van aantrekken, in samenwerking met de plaatselijke groten. Vandaar een nog krasser maatregel: de hardhandige eerste havensluiting van 1655, pas opgeheven in 1657.

Als de Sunan ervaart, dat hij en zijn volk er zelf ook door lijden, terwijl Batavia, zij het met inspanning, het rijstgebrek te boven komt, wordt de sluiting weer opgeheven, doch tevens een nieuw stelsel ingevoerd: in plaats van het nauwe toezicht der centrale ambtenaren door tugurs, komt nu een opperbewind der vier voornaamste strandheren: Japara, Samarang, Pați en Demak. Hollandse gezantschappen mogen thuisblijven; het viermanschap zal zijn Vorst voortaan van al het nodige en wenselijke voorzien, ja zelfs zijn schat verveelvoudigen door handelsondernemingen.

$\mathrm{Zij}$ proberen een handelsmonopolie tegen veel te hoge prijzen, waar de Compagnie niet op ingaat. Dan pogen zij op allerlei verre en door Batavia verboden havens te varen, soms met een eigengebouwd jacht, of in samenwerking met de ervaren Makassaren. Niets slaagt en hun positie wordt hachelijk, wanneer de Compagnie hun verzoeken om geldleningen nadrukkelijk afslaat.

Onderwijl zijn zij het zelf steeds oneens: de tumenggung Pați tegen ng. Marta-Nata van Japara. De laatste overtroeft zijn ambtgenoten, die of ontslagen, of gedood worden. Hij zal het geweest zijn, die 's Vorsten aandacht van de achterstal der strandheren op de eigengereidheid der Nederlanders weet over te brengen: zij weigeren tol te betalen. Hun aanslag op Palembang doet de emmer overlopen: alle havens worden gesloten, ook voor niet-Nederlanders. Bijna twee jaar staat alle zeehandel der Javanen stil, zonder dat de Compagnie toegeeft. Ten slotte moeten de havens weer open; om zijn gezicht te redden, beveelt de Sunan de Nederlanders naar hun vervallen loge terug te keren. Maar wanneer ng. Marta-Nata er niet in slaagt, de verhouding tot Batavia op voor de Sunan eervolle wijze te regelen, betekent dit ook zijn dood. Wrevelig moet de Vorst erkennen, dat de onmisbare Nederlanders hem uit de hand lopen. De achteruitgang van zijn gezag weerspiegelt zich in de eerste tekenen van onrust in het rijk.

Hij tracht nu de macht der strandheren te kortwieken, op tweeërlei wijze. Vooreerst vertrouwt hij in Japara de fiscale en economische zaken toe aan z.g. regerende kooplieden, terwijl de gouverneur met besnoeide middelen van Batavia een gezantschap naar Mataram moet zien los 
te krijgen. Om des lieven vredes wille gaat de Hoge Regering daar drie maal op in $(1667,1668,1669)$, doch de laatste keer vindt de Nederlandse gezant reeds in Samarang de deur gesloten wegens binnenlandse onlusten. Daarna is het natuurlijk uit met de glorieuze ambassades, en wel voor goed. De rampzalige gouverneur wordt, als zovele voorname dienaren, vermoord.

Vervolgens verlaagt de Vorst in veel havensteden zijn gouverneurs tot havenmeesters en draagt het landelijk bestuur aan umbuls op. Van de Nederlanders wordt weinig meer verwacht; zij zijn een prooi der knevelarijen van plaatselijke bestuurders. Geleidelijk wordt de kust een politieke en economische chaos. $\mathrm{Na}$ de Buitengewesten kan de Sunan ook de stranden niet meer onder controle houden. Zo nadert de katastrofe.

In een volgend deel zal nagegaan worden, wat er in Java's binnenlanden woelde. 
H.J. de Graaf - 978-90-04-28657-3 Downloaded from Brill.com $\odot 4 / 26 / 2023$ 02:24:41PM via free access 


\section{BIBLIOGRAFIE.}

\section{Inheemse bronnen.}

In handschrift :

Soerjanagara, Pg. Aria. Babad Sengkalaning Momana. Ms. K.B.G.

Babad Sengkala. Afschr. v. h. Bijbelgenootschap 87 (XIII). Ms. K.B.G. $608 \mathrm{Br}$.

Serat Kanḍa. Ned. Vert., beginnende met het verhaal van Adji Saka. 4 dln. K.B.G. no. 540 (afgekort: S.K.).

\section{Gedrukten:}

Babad Tanah Djawi. Djilid 10-11. Uitg. Balai Pustaka Serie no. 1289 Batawi Sentrum 1940 (afgekort. Babad B.P.).

Babad Tanah Djawi, in proza. Jav. geschiedenis... tot..1647 der Jav. jaartelling. In ... opdracht $\mathbf{v}$. h. Kon. Instituut ... naar de uitgave van J. H. Meinsma ..., vertaald donr W. L. Olthof. 's-Grav. (1941) (afgekort: Babad Meinsma).

Serat Babad Tuban... Tjitakan ke III. Kediri 1936.

Cense, A. A. De kroniek van Bandjarmasin. Santpoort 1928.

Djajadiningrat, H. Critische beschouwing van de Sadjarah Bantěn. Bijdrage ter kenschetsing van de Jav. geschiedschrijuing. Haarlem 1913.

Padma-Susastra, Ki. Sadjarah Dalem pangiwa lan panengen... Sam. 1902 (afgekort: Sadjarah Dalem).

Prawirawinarsa, rd., \& rd. aria Djajengpranata. I. Babad Alit... Welt. 1921 Volklectuur. Serie no. 462.

\section{Europese bronnen.}

\section{Boekwerken:}

Brøndsted, Joh. Vore gamle Tropekolonier.

Calendar (A) of the Court Minutes ... of the E. I. Comp. 1674-76.

Corpus Diplomaticum Neerlando-Indicum ... Uitger. en toegel. door J. E. Heeres. 1e dl. (1598-1650). B.K.I. LVII. 's-Grav. 1907.

Dagh-Register gehouden in 't Casteel Batavia ... 1647-1677. 's-Grav.-Bat. 18881904.

Faber, G. H. von. Oud Soerabaia ... Soerabaia 1931.

Goens, Rijklof van. De vijf gezantschapsreizen naar het hof van Mataram. 164854. Uitgeg. door H. J. de Graaf. 's-Grav. 1956. Werken Linschoten-Verg. LIX. (afgekort: Van Goens).

Haan, F. de. Priangan. De Preanger-regentschappen onder het Ned. bestuur tot 1811 ... 4 dln. Bat. 1910-12. Uitg. K.B.G. (afgekort: Priangan).

Jonge, J. K. J. de. De opkomst van het Ned. gezag in Oost-Indië ... dl. V-VI 's-Grav.-A'dam 1870-72.

Kroeskamp, H. De Westkust en Minangkabau (1665-1668). Utrecht 1931.

Mooij, J. Bouwstoffen voor de Gesch. der Prot. Kerk in Ned.-Indië. 2e dl. Weltevreden 1929. (aangeduid met: Notulen). 
Raffles, Th. St. The History of Java. London 1817. 2 vols.

Rumphius, G. E. De Ambonse Historie... 's-Grav. 1910. 2 dln. Uitg, K.I. (B.K.I. 64).

Schouten, W. Oost-Indische Voyagie... A'dam 1676, 2 dln.

Valentijn, Fr. Oud en Nieuw Oost-Indiën ... Dordr.-A'dam 1724-26. dl. IV. (afgekort: Val.).

Handschriften:

Verschillende stukken uit het Koloniaal Archief, onderdeel van het Algemeen Rijksarchief te 's-Gravenhage. (aangeduid met K.A.)

Notitie ... tot naarrigtingen van ... Jan van den Oppijnen, ... Opperhoofd... in 't Casteel Rotterdam op Maccasser, en van den Capitain Jan Fransz . . . Anno 1669 (opgesteld door Corn. Speelman). Aanwezig op het Arsip Negara te Djakarta.

Tijdschriftartikelen:

Adam, L. Eenige historische en legendarische plaatsnamen in Jogjakarta. Djawa $\mathrm{X}, 1930$.

Brascamp, E. H. B. Houtleveranties onder de O. I. Compagnie. T.B.G. LIX-LXI 1919-22 passim.

Fruin-Mees, W. Winrick Kieft en zijn Rapport over zijn Gezantschap naar Mataram in 1655. T.B.G. LXXII 1932 p. 391-99.

Graaf, H. J. de. De reis van Mangku-Rat IV naar Mataram. T.B.G. LXXXIII 1949.

Graaf, H. J. de. Gusti Pandji Sakti, vorst van Buleleng. T.B.G. LXXXIII 1949.

Graaf, H. J. de. De oorsprong der Javaanse moskee, Indonesië I 1947-48 p. 289305.

Graaf, H. J. de. Soerabaja in de XVIIe eeuw. Djawa 1941.

Graaf. H. J. de. Titels en namen van Javaanse vorsten en groten uit de $16 \mathrm{e}$ en 17 e eeuw. B.K.I. CIX 195/.3

Graaf, H. J. de. De Moskee van Japara. Djawa 1936.

Holle, K. F. Een pijagem van den Vorst van Mataram. T.B.G. XIII 1864.

Leemans, C. De Javaansche tempels bij Prambanan. B.K.I. 1855.

Naber, S. P. l'Honoré. De derde Voijagie van G. Hoecq naer Oost-Indië. Marineblad XXV, 1910-11 p. 193, 289, 422, 533.

Naber, S. P. l'Honoré. In een open sloep van Australië naar Java. Marineblad XXV 1910-11 p. 18.

Roo de la Faille, P. de. Uit den Palembangschen sultanstijd. Feestbundel K.B.G. 1778-1928. II, 316-52.

Rouffaer, G. P. Vorstenlanden. Overdruk uit Adatrechtbundel XXXIV, Serie D, no. 81 blz. 233-378 (1931). 